КИЇВСЬКИЙ НАЦІОНААЬНИЙ УНІВЕРСИТЕТ IMEHI TAPACA ШЕВЧЕНКА

\title{
I.С. ЗАЯРНА
}

\section{МЕТОАИКА \\ АИСТАНЦІЙНОГО НАВЧАННЯ \\ АНГАІЙСЬКОГО АРГУМЕНТАТИВНОГО \\ ПИСЬМА МАЙБУТНІХ ПРАВОЗНАВЦІВ}

Монографія

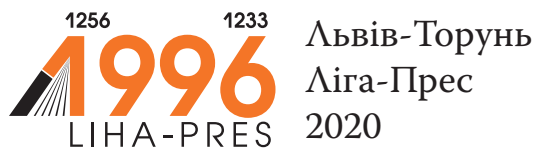




\section{УАК 378.147:34-057.87:811.11'2/'44 \\ 3-40}

\section{Рецензенти:}

О. Б. Бігич - доктор педагогічних наук, професор, професор кафедри метоАики викцадання іноземних мов й інформаційно-комунікаційних технологій Київського націонацьного Аінгвістичного університету;

Ю. В. Ващенко - Аоктор юридичних наук, доцент, професор кафедри аАміністративного права юриАичного факультету Київського націонацьного університету імені Тараса Шевченка;

О. М. Спірін - доктор пеАагогічних наук, професор, член-кореспондент НАПН України, проректор з цифровізації освітньо-наукової Аіяльності АЗВО «Університет менеАжменту освіти»

Рекомендовано Ао Аруку

Вченою радою юридичного факультету Київського національного університету імені Тараса Шевченка (протоком № 8 віА 24.02.2020р.)

\section{Заярна I. C.}

3-40 Методика Аистанційного навчання англійського аргументативного письма майбутніх правознавців : монографія / І.С. Заярна. $-\Lambda$ ьвів-Торунь : Аіга-Прес, 2020. - 264 с.

\section{ISBN 978-966-397-214-5 \\ DOI 10.36059/978-966-397-214-5}

Монографія є одним із перших у вітчизняній науці методики викладання англійської мови Аля спеціальних цікей АосліАженням, присвячених Аистанційному навчанню англійського аргументативного письма майбутніх правознавців. У роботі системно висвітлені теоретичні засади Аистанційного навчання англійського аргументативного письма майбутніх правознавців: вивчено стан Аосліджуваності проблеми; визначено жанри англійського аргументативного письма юристів та їх Аінгвістичні особливості; Аосліджені теоретико-методичні аспекти дистанційного навчання ангАійського аргументативного письма студентів-юристів. Особливу увагу авторка придікяє методиці Аистанційного формування умінь англійського аргументативного письма засобами LMS MOODLE. Сформульовано цілі та зміст навчання англійського аргументативного письма, теоретично обгрунтовано та розроблено підсистему вправ та завдань, створено АиАактичну модель е-навчання англійського аргументативного письма майбутніх правознавців. У третьому розділі монографічного дослідження експериментально перевірено ефективність авторської методики та розроблено методичні рекомендації щодо е-навчання англійського аргументативного письма майбутніх правознавців засобами LMS MOODLE.

Монографія може бути корисною науковцям, викладачам, аспірантам, студентам закладів вищої освіти, які цікавляться як методикою Аистанційного навчання, так і особливостями навчання англійської мови Аля спеціальних цікей (право).

УАК 378.147:34-057.87:811.11'2/'44 
TARAS SHEVCHENKO NATIONAL UNIVERSITY OF KYIV

\author{
Inna ZAIARNA
}

\title{
E-TEACHING ENGLISH ARGUMENTATIVE WRITING TO PROSPECTIVE LEGAL PROFESSIONALS: THEORY AND PRACTICE
}

Monograph

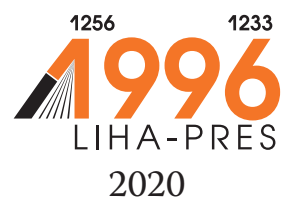


УАК 378.147:34-057.87:811.11'2/'44

\section{Reviewers:}

Oksana B. Bihych - Dr. Habil. (Pedagogy), Professor, Department of Foreign Languages Methodology Teaching and Information and Communication Technologies, Kyiv National Linguistic University;

Yuliia V. Vashchenko - Dr. Habil. (Law), Associate Professor, Administrative Law Department, the Faculty of Law, Taras Shevchenko National University of Kyiv;

Oleh M. Spirin - Dr. Habil. (Pedagogy), Professor, Corresponding member of the National Academy of Educational Sciences of Ukraine, Vice-rector for Research and Digitalization, University of Educational Management

Recommended by the Academic Board of the Faculty of Law at Taras Shevchenko National University of Kyiv (Record No. 8, 24 February 2020)

\section{Zaiarna, Inna}

E-Teaching English Argumentative Writing to Prospective Legal Professionals: Theory and Practice : monograph / I.S. Zaiarna. - Lviv-Toruń : Liha-Pres. 2020. - $264 \mathrm{p}$.

$$
\text { ISBN 978-966-397-214-5 }
$$

$$
\text { DOI 10.36059/978-966-397-214-5 }
$$

The monograph deals with the issue on e-teaching English argumentative writing to law students. The research studies the theoretical aspects of distance teaching English argumentative writing to law students. The author states the problem, determines the genres of English argumentative writing within a legal discourse and studies their linguistic features. Specifics of distance teaching English argumentative writing to law students are examined. Special attention is paid to the development of the abilities in English argumentative writing by means of LMS MOODLE. The aims and the content of teaching English argumentative writing are specified. The author also develops the system of exercises and tasks as well as designs a didactic model for e-teaching English argumentative writing to prospective legal professionals. Chapter III of the research addresses the pilot testing and evaluation of the model for e-teaching English argumentative writing to law students. Guidelines for e-teaching English argumentative writing to prospective legal professionals by means of LMS MOODLE are also developed.

The monograph would be of particular interest to researchers, lecturers, PhD students, students of higher educational establishments who are interested in English for Specific Purposes distance teaching. 


\section{MICT}

ПЕРЕАМОВА

POЗAI 1.

ТЕОРЕТИЧНІ ЗАСААИ АИСТАНЦЙНОГО НАВЧАННЯ АНГАІЙСЬКОГО АРГУМЕНТАТИВНОГО ПИСЬМА МАЙБУТНІХ ПРАВОЗНАВЦІВ

13

1.1 Навчання англійського аргументативного письма юристів як преАмет методичного АосліАження

1.2 Аргументативне мовлення як компонент іншомовної комунікативної компетентності майбутніх правознавців.

1.3 Теоретико-методичні аспекти Аистанційного навчання англійського аргументативного письма студентів-юристів.

POЗАI 2.

МЕТОАИКА АИСТАНЦИИНОГО ФОРМУВАННЯ УМІНЬ АНГАІЙСЬКОГО АРГУМЕНТАТИВНОГО ПИСЬМА МАЙБУТНІХ ПРАВОЗНАВЦІВ

2.1. Цілі та зміст навчання англійського аргументативного письма майбутніх правознавців.

2.2 Аобір мовного та мовленнєвого матеріацу Аля навчання англійського аргументативного письма майбутніх правознавців.

2.3 Етапи та піАсистема вправ і завАань Аһя Аистанційного навчання англійського аргументативного письма майбутніх правознавців

2.4 Модель Аистанційного навчання англійського аргументативного письма студентів-правників. 
PO3AI 3.

ЕКСПЕРИМЕНТААЬНА ПЕРЕВІРКА

МЕТОАИКИ АИСТАНЦІЙНОГО НАВЧАННЯ

АНГАІЙСЬКОГО АРГУМЕНТАТИВНОГО ПИСЬМА

МАЙБУТНІХ ПРАВОЗНАВЦІВ

3.1 Планування та підготовка експерименту.

Розроблення критеріїв та норм оцінювання

англійського аргументативного письма.

3.2 Анаціз та інтерпретація результатів експерименту.

3.3 Методичні рекомендації щодо організації

Аистанційного навчання англійського аргументативного

письма майбутніх правознавців. 


\section{ПЕРЕАMOBA}

У сучасному світі знання англійської мови, як уніфікованого інструменту міжкультурної комунікації, $\epsilon$ надзвичайно важливим Аля професійної Аіяльності юристів. Глобалізаційні процеси, їх швиАкі зміни, що стосуються й професійної Аіяльності правників, вимагають віА майбутнього спеціаліста

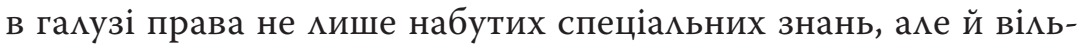
ного волоАіння ангАійською мовою як мовою міжнароАного спіккування. В умовах сьогодення вміння аргументовано виклаАати свої Аумки на письмі англійською мовою є визначаАьним Аля юриста, аАже Аоводити вцасну позицію чи спростовувати аргументи опонентів - це основоположне вміння правника. Так, в умовах зростаючої уніфікації та гармонізації українського законодавства сучасний юрист постійно співпрацює з іноземними компаніями та організаціями, скмадає міжнародні договори, веАе иистування 3 кцієнтами та колегами із різних юрисАикцій, преАстав яє інтереси своїх кАієнтів в європейських судах та комерційних арбітражах. Все це вимагає високого рівня компетентності та зумовлює важАивість оволодіння навичками та уміннями ангАійського аргументативного письма студентами юридичного профілю піА час навчання у закмадах вищої освіти.

ПоряА $з$ цим, глобальні інтеграційні процеси та стрімкий розвиток інформаційних технологій впливають не кише на зміст навчання студентів юридичних $3 \mathrm{BO}$, але й на його форму, що ставить переА теорією та методикою навчання нові завдання: ефективність та Аоступність освіти, навчання без кордонів, навчання протягом життя. ОАним із засобів рішення 
цих викликів може стати Аистанційне навчання, яке покцикане УАосконалювати і розвивати традиційні очні та заочні форми, інтегруючи в собі те краще, що накопичено ними із застосуванням в навчанні можмивостей новітніх інформаційних техномогій. ЗавАяки характерним рисам Аистанційного навчання, таким як гнучкість (зАатність навчатися у зручний Аля студента час), технологічність (використання в навчальному процесі нових Аосягнень інформаційних технологій), якість, яка не поступається традиційному навчанню, соціальна рівність (однакові можливості Аля зАобуття вищої освіти незалежно віА місця проживання, стану зАоров'я і соціального статусу), інтернаціональність (можливість зАобути освіту в навчальних закладах іноземних держав) навчання англійського аргументативного письма засобами Аистанційного навчання створює низку переваг у процесі виконання поставцених навчальних задач і оволодіння необхідними мовними навичками та мовленнєвими уміннями.

Спеціальні наукові Аослідження, присвячені проблемі Аистанційної освіти та її впроваАження в навча^ьний процес, Аемонструють всебічний інтерес зарубіжних і вітчизняних вчених Ао Ааної проблематики та слугують грунтовною теоретичною базою Аля цієї АосліАницької роботи. Теоретичні основи Аистанційного навчання Аосліджувалися Т. Андерсоном (Т. Anderson), А.А. Андреєвим, А.В. Бейтсом (A.W. Bates), В.Ю. Биковим, А.Г. Гавріловою, І.В. Герасименко, М. Аугіамасом (М. Dougiamas), В.Г. Кременем, B.M. Кухаренком, Н.В. Морзе, М.Г. Муром (M.G. Moor), О.М. Спіріним, Г.А. Шиліною, Б.І. Шуневичем, О.М. Харою, Б. Холбергом (В. Holmberg), М.А. Умрик. Психолого-пеАагогічним аспектам Аистанційної освіти присвячені результати наукових розвідок П.Г Асоянц, Е.А. Гурова, С.В. Аобровольської, В.І. Овсянникова, М.А. Смульсон, 
A. Cropley \& T. Kahl, R. Nicholls, R. Wegener \& J.M. Leimeister, R. Wlodkowski. Проблема навчально-методичного забезпечення Аистанційного навчання та методологія створення навчальних Аистанційних курсів розглядалися В.П. АнАрущенком, В.Ю. Биковим, В.В. Вишнівським, Н.В. Жевакіною, Г.О. Козмаковою, В.А. Кравцем, О.О. Нікішовим. Особливий науковий інтерес в межах вивчення методики Аистанційного навчання ангАійського аргументативного письма викмикають роботи вчених-методистів, присвячені особливостям Аистанційного навчання іноземної мови: Ю.В. Батуріної, Г.Р. Біккулової, О.В. Бутенкової, О.В. Жовнич, Н.В. Майєр, В.П. Свиридюк.

У свою чергу, аргументативне мовлення також завжАи було у колі інтересів вітчизняних і зарубіжних вчених з різних галузей знань. Вагомими Аля нашого АосліАження $\epsilon$ результати наукових розвіАок вчених-лінгвістів (А.Н. Баранова, А.А. Бєлової, Ф.Х. ван Еемерена (F. Eemeren), С.А. КАімінської, Б.І. Маленького, В.І. Охріменко, Н.А. Ощепкової, I.I. Пірог, Т.А. Скуратовської, О.Е. Сухарєвої), вчених-правників (Р. Алекси, Т.І. Аудаш, К.В. Каргіна, М.І. Козюбри, Р.А. Аяшенка, П.М. Рабіновича, С. Тульміна (S. Toulmin), Е. Фетеріса (E. Feteris), вчених-логіків (А.Є. Конверського, А.Г. Комахи, А.П.Помітюк, І.В. Хоменко, О.Ю. Щербини), вчених-психолінгвістів (А.С. Виготського, В.П. ГАухова,

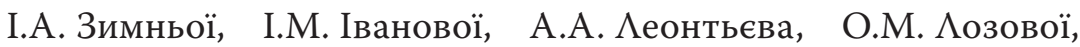
А.Р. Аурії), вчених-психологів (Т.А. Вакалюк, Р.А. ВАоАарчика, Е.Р. Аамірчарі, А.А. Києнко-Романюк, П.Г. Аубочнікова, Н.Ю. Туласинової). Особливий науковий інтерес становлять результати спеціальних АосліАжень вченихметодистів: І.Б. Антонової, О.А. Баранової, Ю.В. Батуріної, Г.М. Гаврикової, В.В. Аацюк, .М. Мусульбес, Т.О. Румянцевої. 
Разом 3 тим, незважаючи на всебічний інтерес вчених та суттєві зАобутки в галузі методики навчання аргументативного мовцення, мусимо констатувати, методика Аистанційного навчання ангАійського аргументативного письма майбутніх правознавців не була предметом спеціального АосліАження i вимагає окремого грунтовного вивчення у межах цього монографічного Аослідження.

Своє системне наукове вирішення знайшии, зокрема, такі завдання: 1) вивчено стан Аослідженості проблеми Аистанційного навчання ангАійського аргументативного

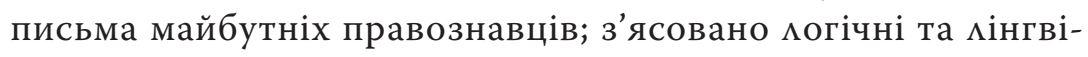
стичні особливості ангмійського аргументативного письма майбутніх правознавців; виокремлено найбільш поширені жанри англійського аргументативного письма в межах юриАичного Аискурсу; 2) АосліАжено теоретико-метоАичні засаАи Аистанційного навчання англійського аргументативного письма: конкретизовано поняття «Аистанційне навчання англійського аргументативного письма», визначено піАходи, принципи та методи; 3) окреслено цілі та зміст навчання англійського аргументативного письма майбутніх правознавців; 4) обгрунтовано критерії Аобору текстового, мовного та мовценнєвого матеріаців Аля навчання ангАійського аргументативного письма майбутніх правознавців; 5) розроблено підсистему вправ та завдань Аля Аистанційного навчання англійського аргументативного письма майбутніх правознавців, створено модель організації процесу навчання; 6) експериментально перевірено ефективність авторської методики Аистанційного навчання англійського аргументативного письма майбутніх правознавців засобами LMS MOODLE та розроблено метоАичні рекоменАації щодо їі ефективного впроваАження у навчамьний процес. 
Реалізація поставлених завдань віАбувацася шияхом застосування системи загальних та спеціальних методів наукового пізнання. Теоретичні методи: аналіз наукової цітератури 3 методики навчання ангмійської мови як іноземної, з психомогії та психолінгвістики, з методики Аистанційного навчання; аналіз чинних програм з іноземної мови за фаховим спрямуванням (право) Аля закцадів вищої освіти, узагальнення теоретичного АосвіАу навчання ангАійського аргументативного письма у вищій школі та застосування засобів Аистанційної освіти Аля навчання студентів-юристів; метоА моделювання Аля обгрунтування та розроблення моделі Аистанційного навчання англійського аргументативного письма майбутніх правознавців; емпіричні методи: метод опитування студентів-правників, практикуючих юристів, викмадачів юридичної англійської мови з метою АосліАження оптимальних шияхів розроблення ефективної моделі Аистанційного навчання англійського аргументативного письма студентів-юристів; експериментальне навчання - 3 метою перевірки ефективності авторської методики; статистичні методи (U - критерій Манна-Уітні та G-критерій знаків) - Аля обробки й анацізу результатів експерименту.

Монографія піАготовлена у 2019-2020 роках на кафедрі іноземних мов юридичного факультету Київського національного університету імені Тараса Шевченка. Основою Аля написання монографії стала Аисертаційна робота на тему: «Методика Аистанційного навчання англійського аргументативного писемного мовлення майбутніх правознавців», захищена 27.06.2019 р. на засіданні спеціалізованої вченої ради К 26.001.49 Київського національного університету імені Тараса Шевченка.

Авторка висловлює щиру подяку своєму науковому керівнику кандидату філологічних наук, професору, 
проректору з науково-педагогічної роботи (міжнародні зв'язки) Київського націонацьного університету імені Тараса Шевченка Петру Олексійовичу Беху, членам кафеАри методики викладання української та іноземних мов і мітератур Інституту фікології та кафеАри іноземних мов юридичного факультету Київського національного університету імені Тараса Шевченка, усім нашим колегам за підтримку та цінні поради піА час піАготовки цього АосліАження. Ми будемо щиро вАячні за змістовні рекомендації та поради А^я їх врахування у наших подальших наукових розвіАках (email: izaiarna@gmail.com). 


\section{PO3AI 11 \\ Теоретичні засади дистанційного навчання англійського аргументативного письма майбутніх правознавців}

У першому розАілі вивчено стан АосліАжуваності проблеми Аистанційного навчання англійського аргументативного письма студентів-юристів; визначено жанри англійського аргументативного письма юристів та їх Аінгвістичні особливості; АосліАжені теоретико-методичні аспекти Аистанційного навчання англійського аргументативного письма майбутніх правознавців.

\section{1 Навчання ангмійського}

аргументативного письма юристів

як преАмет методичного Аослідження

Аргументативне мовлення завжАи було у колі інтересів науковців із різних галузей знань. Спеціальні досліАження $з$ методики, Аінгвістики, психології, психолінгвістики, могіки, теорії права, присвячені Ааній проблематиці, вивчають широкий ряд питань, безпосереАньо пов'язаних із проблемою Аистанційного навчання ангмійського аргументативного письма майбутніх правознавців.

СереА мінгвістів особливий інтерес в рамках нашого Аослідження викмикають роботи А.Н. Баранова ${ }^{1}$, присвя-

1 Баранов А. Н. Аингвистическая теория аргументации (когнитивный подхоА): автореф. Аис. А-ра філол. наук: 10.02.01. Москва: 1990. 48 с. 
чені когнітивному підходу Ао Аінгвістичної теорії аргументації, А.А. Бєлової를 присвячені вивченню аспектів аргументації, Ф.Х. ван Еемерена ${ }^{3}$ про мовленнєві акти в аргументативних Аискусіях, Ае автор обгрунтовує теоретичну модель аналізу Аискусії, спрямованої на вирішення

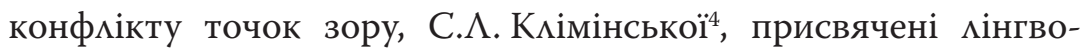
стилістичним засобам реалізації стратегій і тактик переконання в аргументованому Аискурсі, Б.І. Маленького 5 , Ае вчений розглядає аргументативні стратегії в німецькому економічному Аискурсі, B.I. Охріменко ${ }^{6}$ присвячені Аінгвокогнікативним та прагматичним аспектам аргументації в іспаномовній рекмамі, Н.А. Ощепкової7, Ае АосліАниця вивчає стратегії і тактики в аргументованому Аискурсі на матеріалах політичних дебатів, I.I. Пірог ${ }^{8}$, присвячені прагмалінгвістичним особливостям аргументації в сучасній німецькій публіцистиці, Т.А. Скуратовської9,

2 Белова А. А. Аингвистические аспекты аргументации. Киев: Астрея, 1997. 311 с.

3 Еремерен Ф.Х. Речевые акты в аргументативных Аискуссиях: теоретическая модель анализа дискуссии, направленной на разрешение конфликта мнений. Санкт-Петербург: Нотабене, 1994. 239 с.

4 КАиминская С. А. Аингвостилистические среАства реализации стратегий и тактик убежАения в аргументативном дискурсе: на материале англоязычных телевизионных Аискуссий: автореф. Аис. ... канА. филол. наук: 10.02.04; Моск. гос. Аингвист. ун-т. Москва, 2010. 25 с.

5 Маленький Б. I Аргументативні стратегії в німецькому економічному Аискурсі (на матеріаці жанру ток-шоу): Аис. ... канА. філоц. наук: 10.02.04. Київ, 2018. 241 с.

6 Охріменко В. I. Аінгвокогнікативні та прагматичні аспекти аргументації в іспаномовній рекламі: дис. ... канА. філоц. наук: 10.02.05. Київ, 2002. 233 с.

7 Ощепкова Н. А. Стратегии и тактики в аргументативном Аискурсе: прагмамингвистический анализ убеАительности рассужАения: (на материале политических Аебатов): автореф. Аис. ... канА. фимол. наук: 10.02.19; Калужский гос. пеА. ун-т им. К. Э. Циолковского. Калуга, 2004. 18 с.

8 Пірог I. І. Аргументація в сучасній німецькій публіцистиці: прагмалінгвістичний аспект (на матеріалі економічних текстів): автореф. Аис. ... канА. філол. наук: 10.02.04; Харк. нац. ун-т ім. В. Н. Каразіна. Харків, 2009. 20 с.

9 Скуратовська Т. А. Аргументація в американському судовому Аискурсі (на матеріалі справ за участю суду присяжних): автореф. Аис. ... канА. філол. наук: 10.02.04. Київ, 2002. 20 c. 
присвячені аргументації в американському судовому дискурсі (на матеріалі справ за участю суду присяжних), О.Е. Сухарєвої ${ }^{10}$, Ае авторкою вивчається проблема переконливості монологу на матеріалах публічних промов. Результати досліАжень вчених-лінгвістів будуть нами використані Аля розв'язання пробцем, що стосуються основних компонентнів метоАики Аистанційного навчання англійського аргументативного письма: визначення цілей, змісту, технологій та Аопоміжних засобів навчання.

Важмиве значення Аля нашого АосліАження методики навчання аргументативного письма мають наукові зАобутки вчених-логіків. Так, аргументація як категорія науки могіки була також преАметом спеціальних розвіАок таких науковців як В.І. Кірілцов та А.А. Старченко (особливу увагу досліАники приАілили юриАичній аргументації) ${ }^{11}$, А.Е. Конверський (вчений розгляАає поняття і структуру юриАичної аргументаціiі) ${ }^{12}$, А.Г. Комаха (АосліАниця вивчала Аогічний аналіз Аискурсу аргументації у філософії) ${ }^{13}$, А.П. Помітюк (АосліАження авторки присвячене аргументації як преАмету неформальних досліАжень (неформальна могіка та риторична аргументація) ${ }^{14}$, I.B. Хоменко (науковець сформулювала основні правика щодо

${ }^{10}$ Сухарева О. Э. Западная риторическая традиция и проблема убедительности монолога: на материале публичной речи: автореф. Аис. ... канА. филол. наук: 10.02.19; УАмурт. гос. ун-т. Ижевск, 2010. 22 с.

11 Киримлов В. И., Старченко А. А. Аогика: учебник Аця юридических вузов / поА реА. проф. В. И. Киримлова. ИзА. 6-е, перероб. и Аоп. Москва: ТК Велби; ИзА-во Проспект, 2008. 240 с.

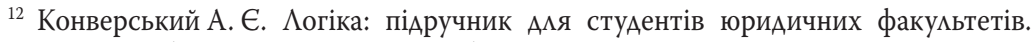
3-тє виА. перероб. та Аоп. Київ: Центр учбової мітератури, 2012. 296 с.

${ }^{13}$ Комаха $\Lambda$. Г. Аогічний анаціз Аискурсу аргументації у філософії: Аис. ... А-ра. філос. наук: 09.00.06. Київ, 2016. 425 с.

14 Політюк А. П. Аргументація як предмет неформальних Аосліджень: неформацьна могіка та риторична аргументація: Аис. ... канА. філос. наук: 09.00.06. Київ, 2015. 220 c. 
структурних елементів аргументації) ${ }^{15}$, О.Ю. Щербина (наукова праця присвячена могічному аналізу юридичної аргументації) ${ }^{16}$. Результати АосліАжень вчених-логіків слугують фундаментом у процесі навчання аргументативного мовцення, вони розкривають зміст та структуру аргументативних процесів (Аоведення, переконання, спростування) та кцючові правица формулювання їх основних структурних елементів (теза, аргумент, Аемонстрація), що Аозволяє нам в межах цієї Аисертаційної роботи визначити зміст навчання аргументативного письма, віАповіАні навички та уміння.

Зважаючи на правову сферу застосування англійського аргументативного писемного мовцення, обумовцену метою нашого Аисертаційного АосліАження, не менш важливими є результати наукових розвіАок вчених-правників, присвячених юридичній (правовій) аргументації. Зокрема, Р. Алекси (юриАична аргументація як раціональний Аискурс) ${ }^{17}$, Т.І. Аудаш (поняттєвий інструментарій АосліАження правової аргументації) ${ }^{18}$, К.В. Каргіна (поняття і елементи юриАичної аргументації) ${ }^{19}$, M.I. Козюбри (юридична аргументація в рамках АосліАження загальної теорії права) $)^{20}$, Р.А. Аяшенка (правова аргументація у сфері правотворчості) $)^{21}$, П.М. Рабіновича (загальнотеоретичні харак-

${ }^{15}$ Хоменко I. В. Аогіка: теорія та практика: піАручник. Київ: Центр учбової мітератури, 2010. 400 с.

16 Щербина О. Ю. Аогічний аналіз юридичної аргументації: Аис. ... А-ра. філос. наук: 09.00.06. Київ, 2014. 424 с.

17 Алекси Р. Юридическая аргументация как рациональный дискурс / пер. с нем. М. В. Антонова // Российский ежегодник права. 2008. № 1.

${ }_{18}$ Аудаш Т. І. Правова аргументація: стан та перспективи дослідження // Вісник Аьвівського університету. 2016. № 62. Серія юридична. С. 3-13.

${ }^{19}$ Каргин К. В. Понятие и элементы юридической аргументации: монография. Новгород: Нижегор. прав. акаА., 2011. 68 с.

20 Загальна теорія права: підручник / за заг. реА. М. І. Козюбри. Київ: Ваіте, 2015. 392 с.

${ }^{21}$ Аяшенко Р. А. Правова аргументація у сфері правотворчості // Учен. зап. Таврич. нац. ун-та им. В. И. Вернадского. Серия «ЮриА. науки». 2012. Т. 25 (64). № 2. С. 74-79. 
теристики правової аргументації) ${ }^{22},{ }^{23}$, C. Тульміна (S. Toulmin) (використання аргументів) ${ }^{24}$, Е. Фетеріса (E. Feteris) (основи юридичної аргументації на матеріалах судових рішень) ${ }^{25}$. Внесок вчених-правників Аля нашої роботи $є$ вагомим і значущим, аАже Аозволяє врахувати особливості юридичної (правової) аргументації, яка не обмежується мише сферою свого застосування, а також враховує колізію між нормами, можливість формулювання правозастосовних рішень всупереч Аослівному тексту норм (contra legem), зокрема у випадках їх застарілості, невіАповіАності правовим цінностям, тощо.

3 точки зору психології в межах вивчення питання метоАики Аистанційного навчання англійського аргументативного письма студентів-юристів нам вбачаються важливими результати Аосліджень, присвячених психологічним та психоАінгвістичним процесам, які супроводжують аргументативне писемне мовлення юристів, ті особливості мислення, які повинні бути враховані в подальшому у методиці навчання англійського аргументативного письма. Зокрема, психомінгвістичні особливості мовленнєвої Аіяльності були преАметом АосліАжень вітчизняних і зарубіжних науковців: $\Lambda . С$. Виготський (психологічні дослідження мислення і мовмення) ${ }^{26}$, В.П. Гцухов (психомінгвістика: теорія мовленнєвої

22 Рабінович П. Правова аргументація (вихіАні загальнотеоретичні характеристики) // ЮриА. вісн. України. 2015. № 17-18. С. 18-29.

${ }^{23}$ Рабінович П. М., Аудаш Т. І. Правова аргументація: терміно-поняттєвий інструментарій досліАження // Вісник Національної академії правових наук України. 2016. № 2 (85). C. 8-20.

${ }^{24}$ Toulmin, S. E. The Uses of Argument. Cambridge, 2003. 259 p.

${ }^{25}$ Feteris E., Feteris T. Foundamentals of Legal Argumentation: a Survey of Theories on Justification of Judicial Decisions // Argumentation Library. Dordrecht: Springer, 1999. Vol. 1. 225 p.

${ }^{26}$ Выготский $\Lambda$. С. Мышкение и речь: психологические исскедования. Москва: ГСЭИ, 1934. 324 с. 
Аіяльності) ${ }^{27}$, І.А. Зимняя (психологія навчання іноземній мові; иінгвопсихологія мовленнєвої діяльності; психологічні аспекти навчання говорінню іноземною мовою) $)^{28},{ }^{29},{ }^{30}$, I.M. Іванова (психолінгвістичні передумови навчання професійно орієнтованого англомовного письма студентів-туризмознавців) ${ }^{31}$, А.А. Аеонтьєв (взаємозв'язок мови, мовлення та мовленнєва Аіяльність) ${ }^{32}$, О.М. Аозова (психологічні аспекти засвоєння іноземної мови) ${ }^{33}$, А.Р. Аурія (основні проблеми нейролінгвістики $)^{34}$. Психологічним особливостям могічного та критичного мисленням присвячені праці Т.А. Вакалюк (підготовка майбутніх учителів інформатики Ао розвитку могічного мислення старшокласників) ${ }^{35}$, Р.А. ВАодарчика (образно-логічне мислення як фактор розвитку інтелектуальної сфери суб'єкту) ${ }^{36}$, Е.Р. Аамірчарі (розвиток професійно-логічного мислення

${ }^{27}$ ГАухов В. П., Ковшиков В. А. Психолингвистика. Теория речевой Аеятельности. Москва: АСТ, 2007. 223 с.

${ }_{28}$ Зимняя И. А. Аингвопсихология речевой деятельности. Москва: Московский психолого-социальный институт; Воронеж: НПО «МОАЭК», 2001. 432 с.

29 Зимняя И. А. Психологические аспекты обучения говорению на иностранном языке. Москва, 1985.

30 Зимняя И. А. Психология обучения неродному языку (на материале русского языка как иностранного). Москва: Русский язык, 1989. 219 с.

31 Іванова I. М. Психолінгвістичні передумови навчання професійно орієнтованого англомовного письма студентів-туризмознавців // Вісник КНАУ. Серія ПеАагогіка та психомогія. 2015. Вип. 4. С. 38-45.

32 Аеонтьев А. А. Язык, речь, речевая деятельность. КрасанА, 2010. 216 с.

33 Аозова О. М. Психологічні аспекти засвоєння іноземної мови: навчацьно-метоАичний посібник. Київ, 2010. 143 с.

34 Аурия А. Р. Основные проблемы нейролингвистики. Москва, 1975.

35 Вакалюк Т. А. ПіАготовка майбутніх учителів інформатики Ао розвитку могічного мислення старшокцасників: теоретико-методологічний аспект: монографія. Житомир: ВиА-во ЖАУ імені І. Франка, 2013. 236 с.

36 Вцодарчик Р. А. Образно-логическое мышление как фактор развития интемлектуальной сферы субъекта: Аис. ... канА. псих. наук: 19.00.01. Красноярск, 2008. 208 c. 
у студентів економічних спеціальностей) ${ }^{37}$, А.А. КиєнкоРоманюк (розвиток критичного мислення студентської молоді як загальнопедагогічна проблема) $)^{38}$, П.Г. Аубочнікова (психологічні механізми розвитку могічного мислення суб'єкту у процесі когнітивної Аіяльності) ${ }^{39}$, Н.Ю. Туласинової (розвиток критичного мислення студентів в процесі навчання іноземній мові) ${ }^{40}$. ЗАобутки вчених-психологів та психолінгвістів, що стосуються закономірностей мовленнєвої Аіяльності, функціонування мислення, пам'яті, сприймання, уваги, мотивації, їх індивіАуамьні прояви будуть нами також обов'язково враховані в межах цієї монографічної роботи, що грунтовно посикить іï наукове значення.

Таким чином, вагомий внесок вчених із суміжних до тематики нашого АосліАження галузей знань (Аінгвістики, психомогії, психолінгвістики, Аогіки, права) скмадає фундаментацьну теоретичну основу Аля подаАьших i Аозволяє всебічно охопити коло питань, безпосередньо пов'язаних 3 методикою Аистанційного навчання англійського аргументативного письма майбутніх правознавців, що i стане нашим наступним кроком в процесі вивчення стану АосліАжуваності проблеми методики навчання аргументативного мовцення.

37 Аамирчари Э. Р. Развитие профессионацьно-логического мышиения у студентов экономических специальностей с помощью коммуникативно-мыслительной технологии погружения в профессию: Аис. ... канА. псих. наук: 19.00.07. Ростов-на-Аону, 2005. 195 c.

${ }^{38}$ Києнко-Романюк $\Lambda$. А. Розвиток критичного мислення студентської молоді як загальнопедагогічна проблема: автореф. Аис. ... канА. пеА. наук: 13.00.01; Ін-т вищ. освіти АПН України. Київ, 2007. 22 с.

39 Аубочников П. Г. Психологические механизмы развития образно-логического мышкения субъекта в процессе когнитивной Аеятельности: Аис. ... канА. псих. наук: 19.00.01. Красноярск, 2004. 212 с.

40 Туласынова Н. Ю. Развитие критического мышления студентов в процессе обучения иностранному языку: Аис. ... канА. пеА. наук: 13.00.01. Якутск, 2010. 203 с. 
Аналіз наукових праць та останніх Аосліджень з методики навчання іноземних мов свідчить про те, що аргументативне мовлення завжАи було у коці інтересів вітчизняних і зарубіжних учених-методистів.

Методиці використання письма як засобу навчання аргументуванню ангАійською мовою у немовному 3ВО присвячене АосліАження І.Б. Антонової. Вчена визначає аргументування як інтелектуацьно-мовленнєву Аіяльність, яка реалізується шияхом побудови певного типу тексту, який може скмадатися зі знаків як писемного, так і усного мовлення. Авторка переконана, що особливістю аргументаційного тексту $є$ те, що в ньому реалі-

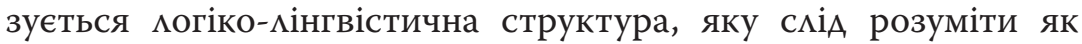
сукупність речень, вимовцених чи написаних аргументатором і аАресованих реципієнту, при цьому аргументатор сподівається, що реципієнт прийме оАну із пропозицій внасліАок прийняття ним інших аргументів аргументатора. АосліАницею також були визначені чотири типи аргументаційного тексту (текст-обгрунтування, текст $з$ частковим спростуванням тези, текст-повне спростування тези, полемічний текст) та їх загальні характеристики: приналежність Ао оАного функціонально-мовленнєвого різновиАу - розАуму; обов'язкова наявність в них таких компонентів як теза та аргументаційна частина; способи аргументації (індуктивний/АеАуктивний); засоби аргументації (прикмади, факти, статистика, цитування); наявність могіко-семантичних схем $^{41}$. Тим не менше, не зважаючи на вагомість резумьтатів АосліАження І.Б. Антонової, вченою не були розглянуті особливості професійної сфери застосування аргументативного писемного мовлення, що безпосередньо впливає на визначення цілей та змісту навчання майбутніх фахівців у галузі права.

${ }^{41}$ Антонова И. Б. Методическая эффективность использования письма как среАства обучения аргументированию в неязыковом вузе: английский язык: автореф. Аис. .... канА. пеА. наук: 13.00.02; Моск. мингвистический ун-т. Москва, 1994. 21 с. 
У межах нашого дослідження інтерес преАставцяють також результати наукових розвіАок О.А. Баранової, присвячених методиці навчання аргументованому писемному висловлюванню. Наукиня визначає аргументативне писемне висловҺювання як продукт мисленнєвої Аіяльності, що являє собою завершений текст, іншими словами єАність змісту та мовної форми, які вкцючають понятійний та емоційні елементи, побуАовані у віАповідності Ао норм писемного мовлення і за законами могіки з метою переконати опонента у правицьності своєї точки зору. О.А. Баранова конкретизує вміння Аля створення писемного роздуму, а саме: загально навчальні уміння, комунікативно-мовленнєві та аргументативні. АосліАницею також розроблені модулі послідовного формування вмінь навчання писемному роздуму (розкриття теми, структурування аргументативного тексту, скмадання аргументативного абзацу, формуҺювання вступу і висновків роздуму, иінгвістичне оформиення писемного Аоведення, комбінування сформованих умінь) ${ }^{42}$. На жаль, вченою не були враховані психологічні та психолінгвістичні особливості навчання аргументативного писемного висловлювання, що не Аозволило вивчити вплив окремих психологічних процесів на якість оволодіння іншомовним аргументативним письмом.

Навчання аргументованому Аискурсу у сфері писемного мовлення у мовних закладах вищої освіти досліджувала С.М. Мусульбес. Вченою було обгрунтовано та змодумьовано процес навчання писемного аргументативного Аискурсу на просунутому етапі навчання у мовному закмаді вищої освіти, розглянуті основні характеристики та структура писемного аргументативного Аискурсу, виокремленні та описані скмадові

${ }^{42}$ Баранова Е. А. Методика обучения аргументированному письменному высказыванию: на материале французского языка, языковой факумьтет: автореф. Аис. ... канА. пеА. наук: 13.00.02; Моск. гос. гуманитар. ун-т им. М. А. Шолохова. Орел, 2013. 23 с. 
писемної мовценнєвої компетенції, що обумовцює розвиток зАібностей Ао писемної аргументації ${ }^{43}$.

Виходячи із завдань нашого Аисертаційного Аослідження, особливий інтерес преАстав яє розроблена С.М. Мусульбес методика навчання писемного аргументуючого Аискурсу, яка передбачає інтеграцію Аінгвістичного, риторичного, АінгвоАиАактичного та психолінгвістичного знання, а також модель навчання аргументативного писемного Аискурсу, яка реалізується в чотири етапи. Так, на першому етапі відбувається орієнтування в комунікативній ситуації, коли студенти ознайомлюються й аналізують тексти-моделі та оволодівають уміннями інтерпретувати писемний аргументативний Аискурс, що особливо актуально в умовах навчання майбутніх юристів, аАже очікуваний результат англійського аргументативного письма

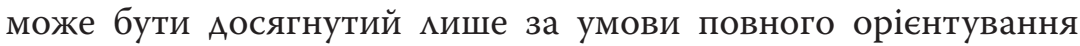
студента в заданій ситуації спілкування, тобто його преАметних знань у віАповідній галузі права; на Аругому етапі відбувається організація матеріалу та планування писемного аргументативного Аискурсу, тобто скмадання плану майбутнього писемного аргументативного Аискурсу; на етапі написання студенти оволодівають Аискурсивною стратегією побудови писемного висловлювання, за чим сліАує четвертий етап редагування вАасного аргументативного Аискурсу, який також вважаємо Аоцільним в процесі Аистанційного навчання англійського аргументативного письма студентів-юристів. Не применшуючи значущості та ефективності, запропонованої С.М. Мусульбес методики навчання аргументуючого Аискурсу у сфері писемного спілкування, вважаємо за доцільне зауважити на необхіАності виокремцення аргументативного етапу, спрямованого на

${ }^{43}$ Мусульбес С. Н. Обучение аргументирующему Аискурсу в сфере письменного общения: (языковой вуз, продвинутый этап, английский язык): Аис. ... канА. пеА. наук: 13.00.02; Моск. гос. Аингв. ун-т. Москва, 2005. 202 с. 
оволодіння знаннями про структурно-композиційні частини аргументації, її способи та форми, а також на оволодіння уміннями аргументативного писемного мовцення.

У рамках АосліАження методики навчання майбутніх філологів англійського усного монологічного персуазивного мовлення, С.В. Білоус було розроблено модель навчання майбутніх філологів англійського усного монологічного персуазивного мовлення в комплексі аргументативних, емотивних і оцінних тактик в жанрах аналітичного коментаря та публічного виступу. Науковцем також були сформульовані методичні та мінгвістичні засади, розроблені етапи навчання, створено підсистему вправ та завдань ${ }^{44}$. Значущими Аля нас $€$ висновки, зроблені С.В. Білоус, щодо аргументативних тактик як скмаАових персуазивного мовлення, які спрямовано впливають на раціональну сферу світосприйняття Аюдини і реалізуються за Аопомогою системи тверАжень, призначених Аля виправАання або спростування якоїсь Аумки. В межах АосліАження навчання аргументативного писемного мовцення цінними, усліА за С.В. Білоус, будемо виокремлювати тактики прямої аргументації, непрямої аргументації, посилання на авторитетну Аумку, актуалізації проблеми, вказівки на способи розв'язання проблем, Аискредитації опонента, акцентування невиконаних обіцянок опонента, опори на загальнолюдські цінності, націленості на майбутнє, єАнання, квантифікації ${ }^{45}$. Разом $з$ тим, враховуючи правову сферу реалізації англійського аргументативного письма, варто також Аодати такі аргументативні тактики як посилання на законодавство, сталу юридичну практику, судові рішення, опору на верховенство права та АюАиноцентризм,

${ }^{44}$ Білоус С. В. Навчання майбутніх філологів англійського усного монологічного персуазивного мовлення: автореф. Аис. ... канА. пеА. наук: 13.00.02; КНУ імені Т. Шевченка. Київ, 2017. 22 с.

45 Там само. С. 5. 
акцентування на протизаконні дії опонента чи його ухимення віА виконання своїх юридичних забов'язань.

Вагомим в рамках нашого Аослідження $є$ внесок Г.М. Гаврицової, яка АосліАжує питання формування писемномовценнєвої аргументативної компетенції у студентів гуманітарних спеціальностей на базі англійської мови. Так, Аослідниця визначає іншомовну писемномовленнєву аргументативну компетенцію студентів гуманітарних спеціальностей як зАатність аАресанта в іншомовному письмовому висловцюванні висувати і обгрунтовувати тезу, 3 метою переконати реципієнта за Аопомогою потрібних аргументів в певному баченні явища, предмету чи ситуації, 3 коректним і свідомим використанням схем і прийомів аргументації. У структурі іншомовної писемномовленнєвої аргументативної компетенції Г.М. Гаврилова виокремлює аргументативні знання, інтегративні аргументаитивні вміння, аргументативні навички та аргументативні якості та здатність. Вчена пропонує модель формування іншомовної писемномовленнєвої аргументативної компетенції, в основі якої процесуально-рефлексивний та результативно-риторичний піАходи. У рамках даної моделі, Г.М. Гаврилова використовує моАульний комплекс вправ з використанням аргументативного мікротексту як одиниці навчання, а контроль рівня сформованості іншомовної писемномовценнєвої аргументативної компетенції визначається критерієм аргументативно-комунікативної грамотності письмового аргументативного тексту, створеного студентом. Крім того, АосліАниця обгрунтовує Аоцільність та ефективність застосування матеріа^ів теорії аргументації в процесі навчання іноземній мові, пропонує комплексний піАхіА до аналізу могіко-композиційної та могіко-семантичної структури аргументативного мікротексту та Аоводить можливість поширення методики створення аргументативних мікротекстів на аргументативні 
макротексти ${ }^{46}$. Результати АосліАжень Г.М. Гаврилової викликають інтерес та слугують фундаментом Аля нашої роботи в межах визначення аргументативної компетенції як скцадової іншомовної професійної компетенції майбутніх юристів.

Методику навчання аргументативного мовлення студентів 3 курсу мовного педагогічного ЗВО вивчала Т.О. Румянцева. Зокрема, було визначено поняття «аргументативне спілкування», Аосліджені його психологічні і прагмалінгвістичні характеристики, виокремлені змістові оАиниці аргументативного спіккування та створена його цогіко-комунікативна модель. Учена Аовела, що формування та розвиток вмінь аргументативного спілкування у студентів 3 курсу мовного 3ВО повинно зАійснюватися з урахуванням психологічних та мінгвістичних характеристик аргументативного спілкування як особливого виАу мовленнєвого спілкування, із властивими Аише йому функціонально-змістовими та структурно-прагматичними вАастивостями, який поєАнує соціаАьно-психо-

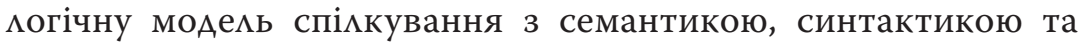
прагматикою аргументації. Щодо самої моделі навчання аргументативного спілкування, то вона реалізується в спеціальному комплексі вправ, побудованих з урахуванням ієрархічно-організованої системи одиниць навчання на основі спеціально віАібраного мовного матеріалу ${ }^{47}$. У межах нашого АосліАження цінними $є$ положення щодо формування та розвитку аргументативних умінь, які будуть нами враховані піА час розробки піАсистеми вправ Аля Аистанційного навчання англійського

46 Гаврилова А. Н. Формирование письменно речевой аргументативной компетенции у студентов гуманитарных специальностей (английский язык): Аис. ... канА. пеА. наук: 13.00.02; Санкт-Петерб. гос. ун-т. Санкт-Петербург, 2011. 277 с.

47 Румянцева Т. А. Обучение аргументативному общению студентов 3 курса языкового педагогического вуза: (на материале немецкого языка): Аис. ... канА. пеА. наук: 13.00.02; Пензенский гос. пеА. наук им. В. Г. Белинского. Пенза, 1999. 240 с. 
аргументативного письма, а саме: дотримання ієрархічної послідовності одиниць навчання аргументитвному спілкуванню: аргументативне висловлювання, аргументативний акт, аргументативний цикц, аргументативний Аискурс; врахування всіх видів конкретних спеціальних аргументативних вмінь та ситуацій спілкування, що моделюють необхідні умови аргмунтаційного спілкування. Разом з тим, Аодаткової уваги в цій роботі вимагає конкретизація аргументативних умінь та комунікативних ситуацій спілкування, притаманні писемному мовценню юристів.

Особливий інтерес в рамках нашого дослідження метоАики Аистанційного навчання англійського аргументативного письма студентів-юристів преАставляє науковий Аоробок Ю.В. Батуріної, яка Аосліджувала формування аргументативних стратегій у магістрів-психологів 3 використанням мережевих комп'ютерних технологій (на матеріалі англійської мови). Зокрема, вченою були виокремлені аргументативні стратегії і тактики, необхідні Аця оволодіння магістрами-психологами англійською мовою, визначені їх психологічні та $і$ інгвістичні особливості. Ю.В. Батуріна обгрунтувала та розробила одиницю організації навчального матеріалу та комплекс вправ Аля оволодіння стратегіями і тактиками аргументації ангАійською мовою магістрами-психологами. Вчена Аекларує, що оптимальна методика навчання стратегіям і тактикам аргументації повинна базуватися на зв'язках між преАметами 1) Аисциплінарного комплексу психологічного напряму, що забезпечує усвідомлення механізмів протікання психічних процесів індивіАуума та застосування вивчених технік Аля піАвищення власного рівня уваги, розвиток пам'яті, покращення сприйняття, розвиток мислення, 2) елементів науки « Аогіка» та «Теорія аргументації, що Аозволяє застосовувати методи могічної побудови і анацізу іншомовного 
мовцення та прийоми, за допомогою яких майбутні психологи можуть підсилювати чи змінювати переконання аудиторії чи окремих мюдей під час практичної Аіяльності, та 3) науки «Риторика», яка передбачає знання правиц мовленнєвої повеАінки та способів побудови виразного мовлення. На Аумку Ю.В. Батуріної, найбільш раціональним способом методичної організації навчального матеріалу $\epsilon$ навчальна макроодиниця - аргументативний модуль, який вкмючає такі структурні компоненти: 1) вступна частина, яка скмадається з інтродукції, тематико-презентаційного та мексико-граматичного блоків; 2) роботу з аргументативним текстом-зразком, що передбачає осмислення тексту, виявлення та аналізу аргументативних стратегій; 3) тренування у використанні стратегій на основі тексту; 4) аргументативний тренінг, який містить аргументативний тренажер та аргументативний консоль; 5) самостійну роботу, спрямовану на продукування аргументативного тексту, що вкцючає мов еннєві вправи з опорою на тему чи ситуацію і створення аргументативного тексту визначеного жанру; 6) квазіпрофесіональна рольова гра, яка базується на актуалізації сформованих аргументативних стратегій; 7) рефмексивного блоку з аналізом могічного, Аінгвістичного, психологічного компонентів аргументативного мовлення, усвіАомленням виконаних Аій, самооцінкою, самокорекцією та самоконтролем. Ефективний комплекс вправ навчання магістрів-психомогів стратегіям аргументації англійською мовою 3 використанням мережевих комп'ютерних технологій, на переконання АосліАниці, має вкАючати наступні групи вправ: персуазивно-націлені; стратегічно та тактично-націлені; електронно-реалізуючі, вкцючаючи пошуково-інформаційні, Аистанційно-комунікаційні, аналітико-спрямовані, в складі яких виконуються рефлексивно-контролюючі вправи Аця зАійснення самоконтролю, самоспостереження з самокорекцією 
та самооцінкою ${ }^{48}$. Виходячи із завдань нашого Аослідження, інтерес робота Ю.В. Батуріної викликає також у зв'язку із застосуванням мережевих комп'ютерних технологій Ао формування аргументативних стратегій у студентів психологічного профілю. ОАнак, останні застосовуються мише як засоби навчання, не змінюючи форми навчання, способу одержання знань та формування необхідних навичок у студентів.

Питанню навчання студентів східного факультету аргументативним стратегіям англомовного Аілового Аискурсу присвячена також наукова робота В.В. Аацюк. Аослідниця Аоводить, що кінцевою метою навчання аргументативних стратегій $\epsilon$ формування аргументативної компетенції, яку слід розуміти як сукупність знань, умінь та навичок, які цежать в основі зАатності висувати та обгрунтовувати тезу 3 метою переконати аАресата у певному баченні явища, преАмета чи ситуації з коректним та свідомим використанням схем та прийомів аргументації, які реацізуються шляхом конкретних мовценнєвих тактик і мовленнєвих актів і є одиницями аргументативних стратегій англомовного Аілового Аискурсу ${ }^{49}$. ПіАсумовуючи, зазначимо: формування аргументативної компетенції, на Аумку В.В. Аацюк, базується на комплексі вправ, які в свою чергу грунтуються на аутентичних матеріалах і мають мовний, умовно-комунікативний та комунікативний характер.

Провівши аналіз теоретичних праць, присвячених аргументативному мовленню та методиці його навчання, в рамках нашого Аослідження вбачаємо за необхідне також проаналі-

${ }^{48}$ Батурина Ю. В. Формирование аргументативных стратегий у магистрантов-психологов с использованием сетевых компьютерных технологий: на материале английского языка: Аис. ... канА. пеА. наук: 13.00.02; Санкт-Петербургский гос. ун-т. Санкт-Петербург, 2015. 275 с.

49 Аацюк В. В. Обучение студентов восточного факультета аргументативным стратегиям англоязычного Аелового Аискурса: Аисс. ... канА. пеА. наук: 13.00.02; СанктПетербургский гос. ун-т. Санкт-Петербург, 2016. 233 с. 
зувати існуючі навчально-методичні праці і комплекси, які використовуються Аля навчання юриАичної англійської мови, а саме на преАмет їх спрямованості на навчання аргументативного юридичного письма. Аля зАійснення Ааного аналізу нами були обрані ряд сучасних вітчизняних і зарубіжних піАручників та навчальних посібників (Аодаток А) та визначені наступні критерії (у межах Ааного Аослідження):

1. Критерій наявності аргументативних модулів як навчальної одиниці.

2. Критерій наявності вправ і завдань, спрямованих на формування і розвиток умінь англійського аргументативного письма.

3. Критерій наявності аргументативного тренінгу (вправ i завдань, спрямованих на тренування навичок могічної/ юридичної аргументації).

4. Критерій жанрової віАповіАності аргументативних текстів-зразків, вправ і завдань сучасній юридичній практиці.

Критерій наявності аргументативних модулів як навчальної одиниці спрямований на виявлення піАручників чи навчальних посібників, які 6 містили розділи (частини) націмені на формування і розвиток аргументативних умінь (уміння аналізувати текст із погляду наявності в ньому аргументативних тактик, уміння визначати мовні засоби вираження, композиційні та жанрово-стилістичні особливості текстів, характерних А^я ангАійського аргументативного письма, уміння відбирати, планувати й організовувати інформацію в письмовому тексті, уміння прогнозувати комунікативну Аоцільність мовних засобів віАповіАно до жанру тексту, тощо).

Аналіз навчально-методичної мітератури за означуваним критерієм не вияв жодного підручника чи навчального посібника, який би містив розділи, націлені на формування аргументативної компетенції. Іншими словами, ми не виявили системного 
піАходу до навчання англійського аргументативного мовлення, який передбачає наявність комплексу вправ і завдань та чіткої структури (вступна частина, професійно-змістовна, мексико-граматичноий блок, аргументативний блок, частина продукування власного тексту студентом, рефмексивна частина).

За критерієм наявності вправ $i$ завдань, спрямованих на бормування $i$ розвиток умінь англійського аргументативного пиьма анаціз підручників і навчальних посібник виявив, що як вітчизняні, так і зарубіжні методисти придікяють увагу формуванню і розвитку віАповідних умінь, тим не менше існує критична різниця в підходах та методах ввеАення, тренування та закріплення відповіАного навчального матеріалу. Розглянемо кожний піАручник більш детально.

Introduction to International Legal English ${ }^{50}$ та International Legal English ${ }^{51}$ видавництва Кембриджського університету $\epsilon$, на наш погляА, одними 3 кращих піАручників 3 юридичної англійської мови. Сім 3 Аесяти та вісім 3 п'ятнаАцяти модулів Ааних Арукованих видань віАповідно містять вправи і завдання на формування i розвиток аргументативного писемного мовцення. ПіАручники містять тексти-зразки, вправи Аһя їх аналізу та усвідомлення, а також завдання, спрямовані на продукування власних текстів віАповіАного жанру. Тексти ААя навчання аргументативного писемного мов ення подаються в контексті загального модуля, присвяченого певній галузі права, в кінці кожного модумя. Підсумкове завдання на продукування власного тексту має комунікативну спрямованість і подається в контексті тієї галузі права, якій присвя-

${ }^{50}$ Krois-Lindner A., Firth M., Legal Trans. Introduction to International Legal English Student's Book: A Course for Classroom or Self-Study Use. Cambridge University Press, 2008.

${ }^{51}$ Krois-Lindner A., Legal Trans. International Legal English Student's Book: A Course for Classroom or Self-Study Use. Cambridge University Press. 2011. 
чений Ааний модуль і текст-зразок. Варто також віАмітити, що автори приАіляють достатньо уваги граматичним та Аексичним особливостям юридичної англійської мови.

ПіАручник Absolute LegalEnglish Book(English for International $L a w)^{52}$, спрямований на піАготовку студентів до скмадання Міжнародного іспиту 3 юридичної англійської мови (ILEC), скмадається 3 дев'яти частин, кожна $з$ яких присвячена окремій галузі права і містить Ава завдання з письма (цист і меморандум). ЗавАання подані в контексті і $€$ комунікативно спрямовані. Аостатньо розробленою $\epsilon$ частина, присвячена юридичному Аексичному матеріалу (юридична термінологія, сталі словосполучення та вирази, юридичне значення слів), в той же час граматичний матеріац залишився поза увагою авторів. Особливістю Ааного підручника $є$ й те, що він зАебільшого націлений на розвиток аргументативних умінь, але не на їх формування, аАже містить завдання на продукування власних текстів без опори на тексти-зразки та віАповіАні вправи і завдання, що Аопомагають аналізувати та усвідомлювати композицію, мовний матеріац, аргументативні тактики тощо.

Підручник English for Legal Professionals ${ }^{53}$, виАавництва ОксфорАського університету, містить шість моАулів, присвячених різним юридичним практикам. Аане видання хоча і містить завдання, спрямовані на розвиток аргументативного писемного мовцення, не передбачає вправ Аця їхнього формування. Характерною особливістю завАань на аргументативне писемне мовцення, представцених в Ааному піАручнику, $є$ їх спрямованість більше на перевірку змістового матеріалу модумя, а не на формування аргументативної компетенції майбутніх юристів.

${ }^{52}$ Callanan H., Edwards Linda. Absolute Legal English Book (English for International Law). Delta Publishing. 2010.

${ }^{53}$ Frost A. English for Legal Professionals Oxford University Press Elt. 2009. 
Аналіз останнього з представлених зарубіжних підручників 3 юридичної англійської мови The Lawyer's English Language Coursebook $^{54}$ не виявив вправ і завдання на формування і розвиток аргументативного писемного мовлення. Хоча дане видання і містить Ава розАіли, присвячені розумінню Аоговорів ангАійською мовою, все ж не містить вправ і завдань на ï продукування і може бути цікавим в рамках нашого досліАження мише в аспекті навчання мексичного матеріалу.

Аналіз українських і російських навчальних посібників та піАручників ${ }^{55}, 56,57,58,59,60,61,62,63,64$ за критерієм наявності вправ і завдань, спрямованих на формування і розвиток умінь англійського аргументативного письма, виявив, що основна увага

${ }^{54}$ Mason C. The Lawyer's English Language Coursebook, Global Legal English Ltd. 2011.

55 Английский Аля юристов - English: We Study Law: учеб. пособие Аля студентов вузов, обучающихся по специальности 021100 «Юриспруденция» / авт.-сост. Немировская Э. А. и Ар. 2-е изА., испр. Москва: Аого Камерон; ИзА-во Омега-,$~ 2006.376$ с.

${ }^{56}$ Аілова англійська мова Аця юристів: навч. посіб. / $\Lambda$. В. Боровецька, $\Lambda$. Т. Жукова, Н. М. Сініцина та ін. - К.: КНЕУ, 2006. - 276 с.

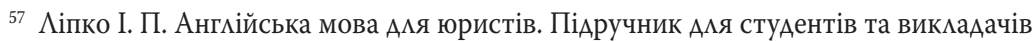
вищих навчальних закмадів. - Вінниця: НОВА КНИГА, 2004. - 208 с.

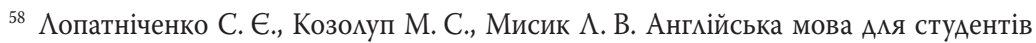
юридичних факультетів. ВиАання юридичного факультету Аьвівського Аержавного університету імені Івана Франка. Аьвів. 1997.

59 Мисик А. В., Савка I. В. Англійська юридична мова: комунікат. аспект: підруч. Аля стуА. юриА. та ін. гуманіт. спец.; за реА. А. В. Мисик. Київ: Ін Юре, 2013. 288 с.

60 Хоменко Н. С. Англійська мова Аля юристів - English for Law Students: Навч. посіб. з англ. мови Аля стуА. юриА. фак.. - К.: МАУП, 2003. - 120 с.

${ }^{61}$ Шевелева С. А. Английский Аля юристов: учеб. пособие Аця вузов. Москва: ЮНИТИ-ААНА, 1999. 495 с.

${ }^{62}$ English for Lawyers. - Аля студентів юридичних спеціальностей - Хмемьницький: Хмемьницький університет управління та права, 2011. - 290 с.

${ }^{63}$ English for Lawyers: підруч. Аля стуА. вищ. навч. закц. / за реА. В. П. Сімонок. Харків: Право, 2011. 648 с.

${ }^{64}$ Just English. Английский Аля юристов. Базовый Курс / Ю. А. Гуманова, В. А. Коромева-МакАри, М. А. Свешникова, Е. В. Тихомирова; поА реА. Т. Н. Шишкиной. Москва: ИКА «ЗерцаАо-М», 2002. 256 с. 
в них зосереджена на інформативній скмадовій та націлена на розвиток мовних знань, умінь та навичок. Вони не містять завдань спрямованих на розвиток аргументативного писемного мовцення, а такі види письма як оповідання, есе, твір, АоповіАь

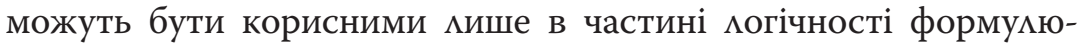
вання власних Аумок і побудови письмового тексту, аце вони не належать Ао тих жанрів аргументативного письма, які $є$ характерними Аля сучасної іншомовної практики юриста в Україні, що значно применшує їх мотиваційну цінність у процесі іншомовної професійно-орієнтованої підготовки майбутніх правознавців.

Аналіз навчально-методичної мітератури за критерієм наявності аргументативного тренінгу виявив, що жоден iз зазначених вище піАручників i навчальних посібників не містить вправ і завдань, спрямованих на тренування аргуметнативних тактик і стратегій. Післятекстові вправи і завАання не вчать анацізувати тексти-зразки на предмет аргументативних тактик і стратегій, використаних автором (як формулюється теза, які аргументи наводяться, на чому вони базуються, як формулюється висновок, тощо). ПреАставлені вправи комунікативного характеру типу Write a letter of advice to your client based on the situation спрямовані скоріше на розвиток загацьних умінь писемного мовлення і передчасно призумують наявність сформованої у студентів аргументативної компетентності. Це призводить Ао того, що тексти, написані студентами, можуть бути композиційно правимьними і мовно багатими, але не зАатними виконати свою основну комунікативну функцію (переконати, Аовести, спростувати, тощо).

Критерій жанрової відповідності аргументативних мекстів-зразків, вправ $і$ завдань сучасній юридичній пракmuці спрямований на виявцення та оцінку письмових текстів, представлених в навчальних підручниках та посібниках, щодо їх придатності формувати іншомовну аргументативну 
професійну компетентність. ПровеАений аналіз свідчить про те, що українські та російські піАручники не віАповіАають вимогам сучасної юридичної практики, аАже пропонують навчати такі універсацьні жанри письмових текстів як есе, оповідання, твірроздум, АоповіАь. У свою чергу, зарубіжні піАручники націлені на розвиток компетенції та практичних вмінь, містять завАання приклаАного характеру на скмадання таких виАів аргументативного письма як мист-порада, меморандум, Аілова електронна кореспонденція, Аист-заява, мист-намір, контракти. Аані види писемного мовлення націлені не мише на знання юридичної термінології, граматики, законів, структури письмового тексту, а на вміння застосовувати ці знання віАповіАно до контексту і ситуації висловлювання. Недоліком зарубіжних піАручників в аспекті їх використання українськими студентами залишається їх націленість на зарубіжне законодавство і відмінну віА України правову систему, що часто ускмаАнює вирішення правових задач і ситуацій студентами українських 3ВО.

Таким чином, аналіз результатів останніх наукових АосліАжень 3 методики викмадання іноземних мов свідчить про всебічний інтерес наукової спільноти Ао навчання аргументативного мовлення, його мексичних, психологічних, могіко-структурних, професійно-орієнтованих особкивостей. Предметом наукових розвіАок вітчизняних і зарубіжних досліАників стали поняття аргументативного мовлення, аргументативні тактики і стратегії, основні характеристики та структура писемного аргументативного Аискурсу, скмадові писемної мовленнєвої компетенції, що обумовлює розвиток зАібностей Ао писемної аргументації; вченими були створені теоретикометодичні моделі навчання аргументативного спілкування та розроблені віАповідні методики. Тим не менше, незважаючи на вагомі результати, Аосягнуті вітчизняними і зарубіжними науковцями, методика Аистанційного навчання англійського 
аргументативного письма майбутніх правознавців не була преАметом спеціального дослідження і вимагає окремого грунтовного вивчення. Аналіз навчально-методичної мітератури Аля навчання юриАичної англійської мови також свіАчить, що аргументативне письмо, хоча і розглядається зарубіжними методистами, не має системного преАставцення в сучасних піАручниках і посібниках. Все це зумовлює актуальність нашого АосліАження та його практичну затребуваність у процесі піАготовки майбутніх юристів.

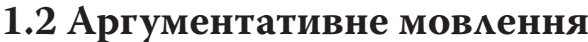

\section{як компонент іншомовної комунікативної компетентності майбутніх правознавців}

Оскільки АосліАження будь-якої наукової проблеми нерозривно пов'язане із визначенням її змістоутворюючих понять, розглянемо Аетально концепт «аргументативного мовцення».

На Аумку С.Г. Оганесяна, аргументативне мовлення - це «зАійснюваний у сфері спілкування скмадений виА обгрунтування, що застосовується аргументатором з метою переконати реципієнта прийняти істинність своєї тези про правицьність, цінність, Аоцільність, необхіАність, правдоподібність, висунутого ним тверАження» ${ }^{65}$. Схоже бачення цього поняття Аемонструють голманАські вчені Амстердамської школи права, які розгляАають аргументативне мовлення як «виА словесної та соціальної Аіяльності, метою якого є збільшення (або зменшення) прийнятності навеАення ряду взаємозв'язаних Аоказів, спрямованих на Аоведення (або спростування) певної точки

65 Оганесян С. Г. Аргументация, её предметная область и возможности: автореф. Аис. … А-ра филос. наук: 09.00.01; Ереванский гос. ун-т. Ереван, 1997. С. 10. 
зору переА раціональним арбітром» ${ }^{66}$. Грунтовне визначення аргументованому мовленню дає О.В. Шелестюк, яка співвіАносить аргументацію 3 переконанням. На Аумку науковця, аргументативне мовмення «характеризується такими видами повідоммення як обгрунтування, пояснення, опис, експлікація, Аоказовість, спростування, екземпліфікація, тлумачення, постулювання, визначення, узагальнення, зв’язок з модусом знань, припущень, поглядів та ін., але зі спеціальним підбором фактів та упорядкуванням аргументів Аця переконання аАресата, іноді з преАставленням тези та аргументів у формі непритаманним ним висловлюванням, Аодаванням емоційно-оцінного модусу, маніпуяяцією 3 модусами погАядів і знань» ${ }^{67}$. Узагальнення наведених визначення Аемонструє змістовну близькість Аоктринальних позицій вітчизняних і зарубіжних АосліАників щодо розуміння сутності поняття аргументативного мовАення.

Виходячи із завАань цього Аослідження, аргументативне мовлення будемо розуміти, усліА за Ю.В. Батуріною, як Авосторонній комунікативний запланований процес 3 метою вирішення аргументативної задачі, під час якого аАресант впливає і змінює іАеї та переконання аудиторії чи окремих слухачів за Аопомогою аргументативнозначущих вербальних способів впливу, результатом чого $є$ прийняття тез і вираження згоди 3 алресантом $^{68}$.

${ }^{66}$ Eemeren F., Grootendorst R., Henkeman F. Fundamentals of Argumentation Theory. New Jersey, 1996. P. 5.

67 Шелестюк Е. В. Текстовые категории аргументативности, суггестивности и императивности как отражение способов речевого воздействия // Вестник Челяб. гос. ун-та. Сер. «Фимология. Искусствоведение». 2008. Вып. 26, № 30 (131). С. 170.

${ }^{68}$ Батурина Ю. В. Формирование аргументативных стратегий у магистрантов-психологов с использованием сетевых компьютерных технологий: на материале английского языка: Аис. ... канА. пеА. наук: 13.00.02; Санкт-Петербургский гос. ун-т. Санкт-Петербург, 2015. С. 31-32. 
Наведене визначення Аозволяє виокремити ряА властивостей поняття «аргументативне мовлення», в яких розкривається його сутність і методологічне навантаження. Зокрема, аргументативне мовлення як комунікативний процес має семантику, синтактику і прагматику. ПіА семантикою аргументативного мовцення, усліА за А.Н. Барановим, будемо розуміти зміст тези і аргументів, піА синтактикою - посліАовність тези та аргументів, піА прагматикою - принципи і правика, що забезпечують доречність, Аієвість і успішність аргументації ${ }^{69}$. Аргументативне мовлення переАбачає поетапний обмін інформацією між комунікантами: віА формування та передавання Ааних автором повіАомлення до їх приймання, розшифрування і використання реципієнтом. Кінцевим продуктом аргументативного мовлення як комунікативного процесу (за І.Б. Антоновою) будемо вважати аргументативний текст в його комунікативних різновидах, які можуть бути Аиференційовані як типи текстів. Тут варто зауважити, що аргументативне мовмення 3 точки зору теорії мовленнєвих актів сліА розуміти, усліА за Г.М. Гаври-

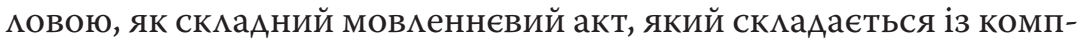
мексу простих мовленнєвих актів інших виАів, що виконують свої комунікативні функції і виокремлюються мише на рівні тексту, а не на рівні речення чи висловлювання, і тільки разом вони функціонують як скмадний мовленнєвий акт аргументації ${ }^{70}$. Погоджуємося також з С.М. Мусульбес, яка виокремлює такі характеристики аргументативного мовлення як функціонально-змістового типу Аискурсу: цілісність, когерентність, завершеність, композиційна оформленість, приналежність

${ }^{69}$ Баранов А. Н. Аингвистическая теория аргументации (когнитивный подхоА): автореф. Аис. ... А-ра фікол. наук: 10.02.01. Москва: 1990. С. 7.

${ }^{70}$ Гаврилова А. Н. Формирование письменно речевой аргументативной компетенции у студентов гуманитарных специальностей (английский язык): Аис. ... канА. пеА. наук: 13.00.02; Санкт-Петерб. гос. ун-т. Санкт-Петербург, 2011. С. 56. 
Ао певного функціонацьно-змістовного типу, екстралінгвістичні особливості акту комунікації (комунікативний намір, комунікативна ціль, врахування сфери і ситуації спілкування $)^{71}$.

Аналіз наукової мітератури ${ }^{72},{ }^{73},{ }^{74},{ }^{75}$ Аозволяє нам визначити основні компоненти Аогіко-цінгвістичної структури аргументації:

- Теза - вихідне положення, істинність якого сліА довести. Теза може формулюватися у формі як категоричного судження так і запитання. НаприклаА, The company performed their obligations under the contract (судження); Is the breach of the contract enough to terminate it and not to be sued for damages? (запитання)

- Аргумент - $о$ огічний Аоказ, істинність якого Аоведена i перевірена практикою і мітить достовірні факти. Ао аргументів віАносять факти Аійсності, теоретичні та емпіричні узагальнення, закони, аксіоми, дефініції, раніше доведені положення. НаприкцаА: Recent case law suggests (посикання на законодавство) that if you do choose to terminate the contract, and if Apple subsequently decide to sue you, the court would rule for you.

- Аемонстрація - могічний зв'язок між аргументами і тезою. Аогічний перехіА віАбувається у формі умовиводу. Таким чином, продемонструвати означає показати, що теза цогічно випливає з прийнятих аргументів за правилами віАповіАних умовиводів.

${ }^{71}$ Мусульбес С. Н. Обучение аргументирующему Аискурсу в сфере письменного общения: (языковой вуз, продвинутый этап, английский язык): автореф. Аис. ... канА. пеА. наук: 13.00.02; Моск. гос. мингв. ун-т. Москва, 2005. С. 11.

${ }^{72}$ Киримлов В. И., Старченко А. А. Аогика: учебник Аця юридических вузов / поА реА. проф. В. И. Киримлова. ИзА. 6-е, перероб. и Аоп. Москва: ТК Велби; ИзА-во Проспект, 2008. 240 с.

${ }^{73}$ Конверський А. Є. Аогіка: піАручник Аця студентів юридичних факультетів. 3-тє виА. перероб. та Аоп. Київ: Центр учбової Аітератури, 2012. 296 с.

74 Хоменко І. В. Аогіка: теорія та практика: підручник. Київ: Центр учбової Аітератури, 2010. 400 с.

75 Toulmin, S. E. The Uses of Argument. Cambridge, 2003. 259 p. 
M.М. Аавриненко, враховуючи трьохчастинну структуру аргументації, виокремлює наступні тактики, які сліА реалізувати піА час навчання аргументативного мовлення студентів-юристів ${ }^{76}$ :

- формування і формулювання тези;

- пошук аргументів на ії підтверАження;

- узагальнення матеріалів та формулювання висновків;

- обгрунтування висновків і насліАків;

- побудова монологічного тексту в письмовій формі.

Наряду з вище викладеним, варто додати, що виконання зазначених Аій піА час навчання аргументативного мовцення буде ефективним та результативним мише за умови дотримання основних правиц щодо структурних компонентів аргументації, сформульованих українською вченою I.В. Хоменко. Зокрема, АосліАниця наголошує на тому, що теза і аргументи мають бути сформульована чітко і ясно; теза має залишатися незмінною впродовж всієї аргументації, а обгрунтування аргументів повинно проводитися незалежно віА тези; аргументи повинні бути висловлюваннями, які повністю або частково обгрунтовані i ïx має бути Аостатньо Аһя обгрунтування тези; віАношення між аргументом і тезою повинно бути принаймні віАношенням піАТвердження (у випадку Аоведення/спростування це відношення має бути відношенням могічного слідування $)^{77}$.

ПіА час навчання ангАійського аргументативного писемного мовлення студентів-юристів ми виокремлюємо, усліА за І.Б. Антоновою ${ }^{78}$, такі види аргументативного мовмення як:

${ }^{76}$ Ааврененко М. М. Профессионально-ориентированное обучение английскому языку студентов миадших курсов юридических факультетов: Аис. ... канА. пеА. наук: 13.00.02; Моск. гос. откр. пеА. универ. им. М. А. Шолохова. Москва, 2004. С. 48-49.

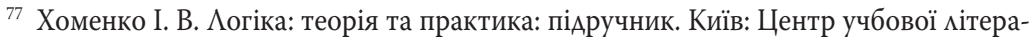
тури, 2010. С. 254-258.

78 Антонова И. Б. Методическая эффективность использования письма как среАства обучения аргументированию в неязыковом вузе: английский язык: Аис. ... канА. пеА. наук: 13.00.02; Моск. мингвистический ун-т. Москва, 1994. С. 111. 
- обгрунтування;

- повне спростування;

- часткове спростування;

- полеміка.

Оскільки продуктом аргументативного мовлення $\epsilon$ аргументативний текст, віАповіАно ми будемо виокремлювати: текст-обгрунтування, текст-повне спростування, текст-часткове спростування, текст-полеміка.

Текст-обгрунтування націкений на Аоведення висунутої тези шияхом преАставцення вичерпних аргументів. Текст-обгрунтування має чітку структуру, яка скцаАається 3 тези, аргументів і демонстрації (висновку). Текст-повне спростування розглядаємо як тип аргументативного тексту, комунікативним завАанням якого $є$ спростування аргументації опонента і формулювання нової тези з їі подальшим обгрунтуванням. ПіА текстом-частковим спростуванням будемо розуміти, усліА за І.Б. Антоновою, такий тип аргументативного тексту, який передбачає часткове спростування тези, коли частина аргументації, що спростовує тезу, провокує неАовіру реципієнта Ао основних Аоказів, тим самим спричиняє недовіру Ао всього тексту. Результатом поєАнання тексту-обгрунтування і тексту-спростування в єАиний текст буде полемічний текст. Характерною особливістю полемічного тексту $\epsilon$ відсутність тези, коли автор наводить аргументи на підтримку різних точок зору, але не висловлює власної позиції ${ }^{79}$.

ПіА час навчання англійського аргументативного письма в залежності віА поставлених переА автором комунікативних задач нами широко будуть застосовуватися такі типи аргументативного тексту як текст-обгрунтування, текст-повне

${ }^{79}$ Антонова И. Б. Методическая эффективность использования письма как среАства обучения аргументированию в неязыковом вузе: английский язык: Аис. ... канА. пеА. наук: 13.00.02; Моск. мингвистический ун-т. Москва, 1994. С. 73-79. 
спростування та текст-часткове спростування. В контексті навчання студентів-юристів прикладом тексту-обгрунтування може бути иист-порада, Аист-попереАження, меморандум; відповідь на Аист-попереАження сліА розгляАати як текст-спростування (повне або часткове). Запорукою ефективного аргументативного мовмення студента-юриста буде врахування як індивіАуальних композиційних особливостей кожного типу, так і врахування притаманних всім типам аргументативних текстів таких характеристик як спосіб аргументації, iї засоби та Аогіко-схематичні схеми.

Не менш важмивим залишається питання добору жанрів письмових текстів, які мають опанувати майбутні юристи. Спираючись на цілі і завдання, які ми ставимо Аля навчання англійського аргументативного письма, стає очевиАним, що такі види письмових текстів як есе, АоповіАі, твори, оповіАання $\epsilon$ махоефективними у досягненні даних цілей. Навчання майбутніх юристів аргументованому писемному мовценню, на наше переконання, має розвивати у студентів уміння, які вони зможуть застосовувати у подальшій професійній Аіяльності і повинно базуватися на таких жанрах юридичних текстів, 3 якими юристи працюють на практиці.

М.М. Аавриненко подіцяє всі юридичні тексти на нотаріальні документи, процесуальні акти, правотворчі документи та юридичну кореспонденцію ${ }^{80}$. Група вчених Гонконгського університету на основі грунтовного аналізу існуючої науково-методичної мітератури Аһя навчання юридичної ангАійської мови як іноземної виокремлюють такі жанри юридичного писемного мовлення: Аосьє (короткий опис) судової справи (a case brief), есе, спрямоване на вирішення юридичної проблеми

${ }^{80}$ Ааврененко М. М. Профессионацьно-ориентированное обучение английскому языку студентов миадших курсов юридических факультетов: Аис. ... канА. пеА. наук: 13.00.02; Моск. гос. откр. пеА. универ. им. М. А. Шолохова. Москва, 2004. С. 34. 
(a problem-solving essay), апеляційна записка (an appellate brief), меморандум (a memorandum), юридичні кисти (legal letters), Ао яких вчені віАносять Аист-пораАу, Аист-вимогу, Аист-висновок та інші, контракти (contracts), аффідевіти (affidavits), кмопотання (a motion), судові рішення (court decisions) ${ }^{81}$. Aле преАставлені китайськими вченими жанри юридичних текстів чи їх класифікація, надана М.М. Аавриненко, все ще не Аозволяють нам виявити ті жанри, які будуть найбільш ефективними Аһя навчання англійського аргументативного письма студентівюристів, так як належать Ао різним типів мовлення.

Щоб виявити найбільш ефективні Аля навчання англійського аргументативного письма жанри юридичних текстів, ми звернулися Ао кмасифікації юридичних текстів, запропонованої американським професором П.М. Тірсмою (Peter M. Tiersma). Як зазначає науковець, всі юридичні тексти за типами мовлення можуть бути поАілені на три категорії: Аекмаративні, описові та переконливі ${ }^{82}$. Виходячи 3 мети і завдань нашого АосліАження інтерес становить група текстів, що належить Ао переконцивого писемного мовлення, Ао якої ми буАемо віАносити процесуальні акти і юриАичну кореспонденцію. Разом 3 тим, зважаючи на часові рамки, обмежені кількістю годин, що відвоАяться у навчальних планах на вивчення дисципліни «Іноземна мова» Аля студентів спеціальності 081 «Право», ми не можемо вкАючити в навчальний процес усі види процесуальних актів та юриАичної кореспонденції. Щоб виокремити найбільш ефективні жанри англійського аргументативного письма, що віАповіАають поставленим нами цілям і завданням, ми провеки опитування на преАмет тих жанрів, які $є$ найбільш вживані в сучасній

${ }^{81}$ Candlin C. N., Bhatia V. K., Jensen C. H. Developing legal writing materials for English second language learners: Problems and perspectives // English for Specific Purposes. 2002. No 21. P. 304-306.

${ }^{82}$ Tiersma P. M. Legal Language. Chicago, 1999. P. 139. 
англомовній юридичній практиці (Аодаток Б). В опитуванні взяли участь 38 практикуючих юристів, сереА яких керівники юридичних компаній, аАвокати, начальники юридичних управмінь та департаментів органів виконавчої влади та місцевого самоврядування, судАі та нотаріуси.

За результатами опитування ми виокремили такі жанри Аля навчання аргументативного письма студентів-юристів: a letter of advice - $и$ ит-порада; a memorandum - меморандум; a letter before action -

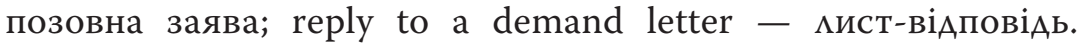
Розглянемо їх детально.

1ucm-nорадy (a letter of advice) визначаємо як письмовий виА комунікації між автором і реципієнтом, піА час якої автор (юрист) пропонує шляхи вирішення юридичної проблеми в інтересах реципієнта (кцієнта), шияхом анацізу Аіючого законодавства та існуючої юридичної практики ${ }^{83}$. Професор школи права Уайднерівського університету Аманда Сміт (Amanda Smith) виокремлює наступні вмастивості киста-поради, які $€$ актуальними в контексті формування у студентів умінь аргументативного писемного мовцення: навчає іАентифікувати юриАичну проблему, проводити Аослідження, аналізувати закони, виражати свої думки у письмовій формі, аргументувати свою позицію ${ }^{84}$.

Проведений аналіз 10 автентичних зразків мистів-пораА Аозволив виокремити такі структурно-композиційні частини

${ }^{83}$ Zaiarna I. Letter of Advice as a Type of English Reasoning Writing of Law Students: Teaching Methods and Techniques / I. С. Заярна // Актуальні питання державотворення в Україні: матеріали Міжнародної науково-практичної конференції (20 травня 2016 року) / РеАкол.: А.ю.н. І. С. Гриценко (голова), к.ю.н. І. С. Сахарук (відп. реА.) та ін. - У 3-х томах. - Том 3. - К.: ВПЦ «Кийвський університет», 2016. С. 287-288.

${ }^{84}$ Smith A. Preparing for Practice from behind the Bench: Opinion Writing as the «Heart and Soul» of the First Semester of Legal Writing // The Journal of the Legal Writing Institute. 2012. Vol. 18. P. 270-271. 
миста-поради: вступний абзац, в якому автор зазначає причину та мету написання Ааного миста; короткий викмаА фактів, Ае автор стисло виклаАає найбільш суттєву інформацію щодо справи, на вирішення якої спрямований Ааний письмовий текст; формулювання правового питання вирішення проблеми, 3 якою звернувся реципієнт Ааного миста; юридична пораАа, Ае автор на базі чинного законодавства та існуючої юридичної практики знаходить вирішення Ааного питання та формулює власні висновки; пропозиція наступних Аій, Ае автор зазначає можииві заходи Аля (шияхи) реалізації запропонованої поради; закмючний абзац містить заклик Ао подацьшої співпраці та комунікації у разі виникнення у реципієнта додаткових питань, пов'язаних $з$ даною справою.

Важливим аспектом киста-поради як виду аргументативного писемного мовлення юриста $є$ правовий контекст. АнаАіз навчальних планів та програм провіАних юридичних заклаАів вищої освіти, Аозволив виокремити наступні ситуації спілку-

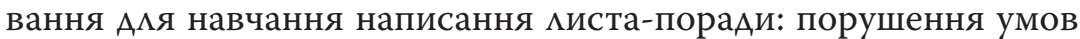
Аоговору однією із сторін (Contract Law), незаконне звільнення з роботи (Employment Law), створення бізнесу та обрання типу суб'єкту господарювання (Company Law), оренда та суборенда житлового/комерційного приміщення (Real Property Law), порушення авторського права (Intellectual Property Law).

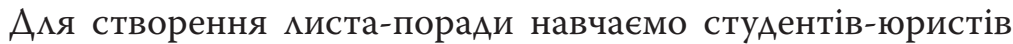
конструювати тексти-обгрунтування за кмасичною модемлю: наведення тези (у нашому випадку, формулювання правового питання), аргументів (посилання на чинне законодавство та існуючу юридичну практику) та демонстрації (формулювання власних висновків та шляхів вирішення правової проблеми).

Аналіз автентичних текстів-зразків дозволив також виокремити такі мовні засоби вираження, які $€$ об'єктом навчання студентів-юристів: 
Аексичні одиниці: The legal issue here is ...; Recent case law suggests that ...; Under these facts, a court would likely apply ...; The courts that have considered this question focus on ...; Applying these legal rules to ...; To sum up, based on the facts as I have recited them in this letter, I believe that ... The facts of our case raise the issue of ...; You told me that ...; In relation to ...; One of the terms provide that ...; You will be liable for ...; Due to the circumstances under which ...; The law is very clear on problems such as yours ... .

Граматичні структури: Present Simple (The legal issue here is ...; Recent case law suggests that ...); Present Continuous; Past Simple (You told me that ... ); Future Simple (You will be liable for ...); Present Perfect (The courts that have considered this question focus on ...); Conditionals (If the term is ..., you will be able to ...; You were unable ... if this term would be interpreted as ...); Gerund (Thank you for coming ...; without being liable for damages ...); Infinitive (To sum up ...; I am writing to summarise ...); Participle (Applying these legal rules to ...); Modal verbs (can; could; should; must); Possessive Case; Degrees of Comparison.

Оскільки реципієнтом Аиста-поради ймовірно $є$ Аюдина без юриАичної освіти, важливо уникати вживання скмадних професійних термінів, матинських виразів, архаїчних слів, юридичного жаргону. Вбачаємо недоцільним у рамках написання киста-п оради використовувати прийменникові словосполучення, незвичний порядок слів, пасивні конструкції, номіналізацію, які роблять синтаксис юридичної англійської мови скмаАним Аля сприймання не-юристами і призводять Ао непорозуміння.

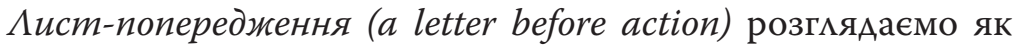
виА юриАичного аргументативного писемного мовлення, націменого на попередження можиивого судового позову. АистпопереАження скмаАається юристом на піАтримку позиції свого кАієнта, аАресований іншій стороні спору i, як правицо, містить заклик на урегулювання суперечки в Аосудовому поряАку. 
Аист-попередження, погоджуємося 3 позицією британських вчених-методистів, має містити посилання на справу або кАієнта, Аетальний опис його скарги, огляА Аоказів на піАтримку позиції кцієнта та імена і аАреси свідків, детаці можмивих правових засобів примусу та законодавства, можмиві шляхи врегулювання конфлікту в Аосудовому порядку ${ }^{85}$. Ао структурно-композиційних частин миста-попереАження віАносимо: посилання на справу або кцієнта; короткий виклад фактів, де автор стисло виклаАає хронологію подій, що призвели до виникнення спору; аргументи на користь позиції Вашого кАієнта, що Аемонструють його виграшну позицію у справі у випаАку позову; закмик Ао врегулювання спору в досудовому порядку.

Аналіз навчальних планів та програм провіАних юриАичних заклаАів вищої освіти, Аозволяє виокремити наступні ситуації спілкування Аля навчання написання миста-попереАження: порушення умов контракту однією із сторін (Contract Law), незаконне звіцьнення з роботи (Employment Law), халатність з боку мікаря/майстра манікюру (Tort Law), незаконне позбав-

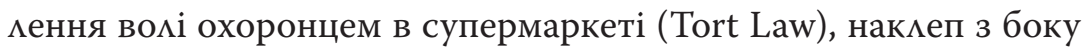
3MI/роботодавця/колеги (Tort Law), несплата орендної плати (Real Property Law), порушення авторського права (Intellectual Property Law).

Аргументативну частину миста-попередження скмадуть тексти-обгрунтування, Ае формулювання обвинувачення постражАалої сторони будемо розгляАати як тезу, наявні матеріальні докази та посицанням на законодавство - як аргументи, висвітлення виграшної сторони кАієнта - як Аемонстрацію.

Аля написання миста-попередження характерні такі мовні засоби вираження:

${ }^{85}$ Krois-Lindner A., Firth M., Legal Trans. Introduction to International Legal English Student's Book: A Course for Classroom or Self-Study Use. Cambridge University Press, 2008. P. 91. 
Аексичні оАиниці: We are instructed by the above named ...; in connection with ...; We understand that ...; We are informed that ...; In fact ...; In light of your actions of ...; It is clear that our client would be fully entitled to ...; Due to the circumstances under which ...; Our client would stand excellent prospects of success should she decide to pursue a claim for ...; However, our client would be prepared to discuss alternative means by which this matter might be resolved. Our instructions are to commence proceedings against you if we do not receive satisfactory proposals for settlement of this matter within 14 days. In relation to ...; One of the terms provide that ...; We are instructed that ...; Our client has suffered ...; This is covered by ...; The terms and conditions specifically provide ...; Our client informs us that ...; Alternatively; It is our intention to ...; We require you to ...; You will be liable for ...; On behalf of ... .

Граматичні структури: вживання часів групи Simple (Our client informs us that ...; You will be liable for ...), Continuous (I am writing to ...) Perfect (There has been no previous criticism of our client's work), умовні речення (Our instructions are to commence proceedings against you if we do not receive satisfactory proposals for settlement of this matter within 14 days.), конструкцій пасивного стану (We are instructed by the above named ...; we are informed ...), герундія (I look forward to hearing from you as soon as possible), інфінітива (Our instructions are to commence proceedings against уоu ...), модальних дієслів (can; could; should; must).

Характерним Аля мексичного i граматичного матеріалу миста-попереАження $є$ вживання таких особливих рис юриАичної ангАійської мови як використання правових термінів (chain of title; easement; escrow; stamp duty), слів, які мають відмінне віА загальної англійської мови значення (consideration; assignment), проформ (the said), матинських виразів (ipso facto; de jure; ad hoc; inter alia), скмадних прийменникових зворотів (hereinafter; notwithstanding), Аовгих речень та номіналізації. 
Biдnовідь на лист-попередження (reply to a letter before action) в межах навчання англійського аргументативного письма студентів-юристів розглядаємо як жанр юридичного аргументативного писемного мовцення, націленого на часткове або повне спростування пред'явлених вимог іншою стороною та/або на обгрунтування власної правової позиції з метою врегулювання існуючого спору. Аргументативну частину тексту віАповіАі на мист-попереАження скмаАають тексти-повного спростування тези та/або тексти-часткового спростування тези. Комунікативним завданням киста-відповіді $€$ повне або часткове спростування аргументації опонента і формулювання власної позиції (тези) з ії подальшим обгрунтуванням (навеАенням аргументів та представлення висновків). Як зазначає С.В. Білоус, в основу тексту-спростування покцадено антитезу, яку необхідно спростувати шияхом преАставлення контраргументів та прикцадів, які спростовують антитезу; Аалі аАресат формулює висновок-тезу, яка $€$ переконанням аАресата щодо існуючої ситуації ${ }^{86}$.

ВіАповіАно до існуючої міжнародної юридичної практики виокремимо наступні структурно-композиційні частини

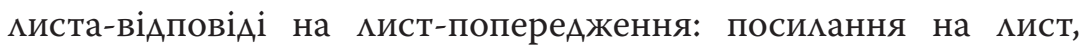
віАповіААЮ на який $€$ Ааний текст; вступний абзац, в якому автор зазначає причину та мету написання даного Аиста; формуюювання спростування на висунуті обвинувачення; наведення аргументів, які заперечують висунуті обвинувачення; формулювання вцасних вимог щодо врегулювання суперечки.

Професійні комунікативні ситуації спілкування, які ми будемо використовувати піА час навчання ангмійського аргументативного письма студентів-юристів, віАповідають ситуа-

${ }^{86}$ Білоус С. В. Навчання майбутніх філологів англійського усного монологічного персуазивного мовлення: Аис. ... канА. пеА. наук: 13.00.02; КНУ імені Т. Шевченка. Київ, 2017. C. 47. 
ціям, характерним Аля написання миста-попередження в межах вивчення тем Contract Law, Tort Law, Company Law, Intellectual Property Law, Family Law, Employment Law та інші.

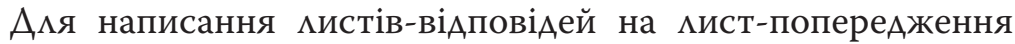
притаманні такі Аексичні одиниці і граматичні структури:

Аексичні одиниці: We write to advise ...; Our client denies completely the version of events in your letter of ...; We can confirm that ...; We look forward to receiving ...; we will take steps to issue proceedings ...; The legal issue here is ...; Recent case law suggests that ...; Under these facts, a court would likely apply ...; The courts that have considered this question focus on ...; Applying these legal rules to ...; In relation to ...; One of the terms provide that ...; We are instructed that ...; Alternatively; It is our intention to ... .

Граматичні структури: вживання переважно часів групи Simple активного стану (We can confirm that ...; We cannot accept the allegations ...); герундія (Our client denies ever having made any reference ...), інфінітива (... have no option but to file ...), модальних дієслів (can; could; must; should).

Юридичний меморандум (a legal memorandum), як зазначається в Програмі американської асоціації адвокатів 3 юридичного писемного мовцення, $\epsilon$ оАним 3 основних і найпоширеніших видів писемного мовлення юриста, «оскільки він формує базові навички, що необхіАні всім студентам юриАичних факультетів і юристам, щоб ефективно передавати на письмі свою аналітичну роботу» ${ }^{87}$. Погоджуємося 3 Аумкою американського науковця Марка ГениАжа (Mark Gannage) про те, що меморандум $\epsilon$ найбільш всеосяжним письмовим юридичним Аокументом, спрямованим на звітування про результати правового Аослідження; він узагальнює та аналізує

${ }^{87}$ Brody S., Kuntz C., Neumann R. and Walter M. Source Book on Legal Writing Progress, American Bar Association. 1997. P. 21. 
віАповіАний закон та його застосування Ао конкретної ситуації $^{88}$. Меморандум спрямований на об'єктивний аналіз справи, виявлення іï сильних і слабких сторін, «які піАтверАжуються фактами і аргументами» ${ }^{89}$.

Структурно-композиційні частини меморандуму, на думку зарубіжних вчених, можуть змінюватися в залежності віА особливостей кожної окремої справи і навіть власного стиця автора ${ }^{90}$. ОАнак, більшість науковців висловлюють спільну

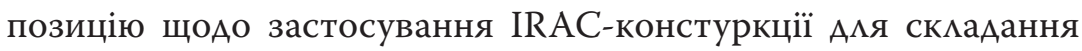
юриАичного меморандуму. IRAC-конструкцію розуміємо як акронім, де Issue - юридичне питання, Rule - судова постанова, Analysis - аналіз, Conclusion - висновок. Крім того, IRAC-конструкція віАповіАає структурі тексту-обгрунтування, який межить в основі аргументативної частини юриАичного меморандуму, де теза буде сформульована у формі юридичного питання, аргументами $є$ норми закону та судові постанови, а демонстрація буде виражена у висновках.

Враховуючи світовий АосвіА та практику, в межах навчання англійського аргументативного письма студентів-юристів, виокремимо наступні структурно-композиційні частини юридичного меморандуму: заголовок, Ае зазначаються імена автора і реципієнта, Аата скмадання та преАмет Ааної справи; юридичне питання, сформульоване у віАповіАності з фактами справи; посилання на судову практику і законодавство, безпосередньо пов'язаних із Ааною справою; аналіз існуючих матері-

${ }^{88}$ Gannage M. Structure your legal memorandum // Perspectives: Teaching Legal Research and Writing. Fall. 1999. Vol. 8. URL: https://info.legalsolutions.thomsonreuters.com/ pdf/perspec/1999-fall/1999-fall-11.pdf

${ }^{89}$ Write a successful memo. URL: http://www.lexisnexis.com/documents/ pdf/20151221040917_large.pdf

${ }_{90}$ Preparing a legal memorandum. URL: http://legalresearch.org/writing-analysis/ legal-memorandum/ 
алів та визначення сильних і слабких сторін справи; висновок автора, який $\epsilon$ безпосередньою віАповіААю на поставлене юриАичне питання.

ПіА час навчання написання юридичного меморандуму нами визначені такі ситуації спіккування, характерні Аля Ааного жанру (згіАно з результатами аналізу навчацьних планів та програм провіАних юридичних закмадів вищої освіти): юридичні насліАки розірвання контракту (Contract Law), необIрунтоване звинувачення (Tort Law), незаконне використання торгової марки (Intellectual Property Law), порушення авторського права (Intellectual Property Law), зАиття та поглинання компаній (Company Law), оренда нерухомості закордоном Аля iï подальшої зАачі в оренду (Real Property Law), порушення умов міжнародного права (International Law) та інші.

Аля написання юридичного меморандуму використовують такі мовні засоби вираження:

Аексичні одиниці: The legal issue here is ...; Recent case law suggests that ...; The law is clear that ...; However, there is a significant risk that ...; In summary ...; There are several recent cases debating this issue ...; The tendency in the more recent cases has been to ...; This case comes out strongly in favour of ... and therefore supports the position our client wants to take with respect to ...; When considered together and analyzed, the combined effect of this case law appears to be as follows ...; On the other hand ...; Thus ...; In this case ...; As a result of this analysis ...; One way would be to ... .

Граматичні структури: вживання часів групи Simple (This case comes out strongly in favour of ...), Continuous, Perfect (The tendency in the more recent cases has been to ...), скмадного підмета (The combined effect of this case law appears to be as follows), герундія (without being liable for damages ...), інфінітива (We would like to summarise ...), модальних Аієслів (can; could; must; should). 
Оскільки юриАичний меморандум є Аокументом, автором і реципієнтом якого $є$ особи $з$ юриАичною освітою, Аця нього будуть характерні мексичні і граматичні характеристики, притаманні юриАичній письмовій англійській мові (вживання скмадних професійних термінів, матинських виразів, архаїчних слів, юриАичного жаргону, прийменникових словосполучення, незвичного поряАку слів, пасивних конструкцій, номіналізації, тощо).

ПіА позовною заявою (a legal complaint) ми розуміємо такий виА аргументативного писемного мовцення студента-юриста, який містить вимогу про примусовий захист порушених прав чи інтересів кцієнта в установленій процесуальним законом формі. Позовна заява як процесуальний документ містить обвинувачення проти відповідача, визначення норм матеріального права, порушених віАповіАачем; зазначення фактів, що призвели Ао спору, і вимог позивача на відновмення справедливість ${ }^{91}$.

ПіА час написання позовної заяви у студентів-юристів формуються такі необхідні аргументативні уміння як формумювання тези та пошук аргументів на іiі підтвердження (як правило, Ажерелом юридичної аргументації $\epsilon$ норми матеріального права, судові рішення вищих судів, нотаріальні та правотворчі Аокументи), узагальнення матеріалів, формулювання та обгрунтування висновків, скмадання монологічного письмового висловлювання. Аргументативну частину позовної заяви скмаАуть тексти-обгрунтування.

На віАміну віА інших виАів аргументативного писемного мовлення, розглянутих в межах Ааного монографічного АосліАження, позовна заява як процесуальний Аокумент має чітко визначені структурно-композиційні елементи. А саме: преАстав-

${ }^{91}$ Federal Practice Manual for Legal Aid Attorneys. Drafting a complaint. URL: http://www.federalpracticemanual.org/chapter4/section1 
цення фактів, де надається грунтовне пояснення наявних фактів по справі; перелік сторін по справі із зазначення даних позивача і віАповіАача; підстави подання позову, Ае обгрунтовуються звинувачення проти відповідача із посиканням на порушені норми матеріального права; визначення юрисАикції суду, який має право розгляАати та виносити рішення по Ааній справі; місце розгляду справи та, безпосередньо, зміст позовних вимог ${ }^{92}$.

Аналіз навчальних планів та програм провіАних юридичних 3ВО, Аозволив виокремити характерні професійні комунікативні ситуації спілкування піА час навчання написання позовної заяви: порушення умов контракт (Contract Law), подіц майна подружжям (Family Law), визнання шлюбу недійсним (Family Law), незаконне звільнення (Employment Law), розголошення персональних Ааних (Information Law), порушення авторських прав (Intellectual Property Law), незаконне виселення (Real Property Law), халатність (Tort Law), незаконне зайняття земельної дікянки (Real Property Law).

А^я написання позовної заяви використовуємо такі мовні засоби вираження:

Аексичні одиниці: plaintiff; defendant; Plaintiff brings forth the following causes of action and alleges the following ...; Plaintiff brings forth the following counts and allegations supporting his cause of action ...; The plaintiff, complaining of the defendant herein, alleges and says ...; The Complaint of the Plaintiff respectfully shows and alleges as follows ...; The Plaintiff herein is ...; Defendant failed to ...; Wherefore, Plaintiff seeks ...; Wherefore, plaintiff prays judgment against defendant ...; the Court may deem just and appropriate ...; By reason of the facts and circumstances stated above ...; Wherefore, Plaintiff demands judgment against Defendant in the sum of ... .

${ }^{92}$ Civil Law Self-Help Center. Filing A Complaint To Start Your Case. URL: http://www.civillawselfhelpcenter.org/self-help/lawsuits-for-money/pleading-stagefiling-a-complaint-or-responding-to-a-complaint/241-filing-a-complaint-to-start-your-case 
Граматичні структури: вживання переважно часів групи Simple активного стану (Plaintiff brings forth the following causes of action ...); Participle (By reason of the facts and circumstances stated above ...), модальних дієслів (the Court may deem just and appropriate ...).

Анаціз 12 зразків текстів позовних заяв, що використовуються в існуючій судовій практиці країн загальної системи права, Аозволяє нам стверджувати, що вживання характерних рис, притаманних юридичному писемному мовленню, є вкрай актуальним під час написання цього жанру, а відтак вимагає спеціальної уваги у процесі роботи наА мексичним і граматичним матеріалом. Зокрема, вживання правових термінів (escrow; easement; damages), матинських виразів (ad hoc; inter alia; ipso facto), зворотного порядку слів (title absolute), скцаАних прийменникових зворотів (hereinafter; notwithstanding; therein).

Таким чином, проведене досліАження п'яти жанрів англійського аргументативного письма юриста Аозволило нам сформулювати їх визначення, виокремити характерні Аля їх використання професійні комунікативні ситуації спілкування, а також мовні засоби вираження. Крім того, ми описали структурно-композиційні елементи цих жанрів та визначики типи аргументативного тексту, які застосовуються в залежності віА поставленої переА автором комунікативної задачі.

Підсумовуючи вище викладене, зазначимо, що аргументативне мовлення $\epsilon$ невіА’ємним компонентом іншомовної комунікативної компетенції майбутніх юристів, яке сліА розуміти як комунікативний процес, націлений на вираження своїх Аумок 3 метою переконання в істинності чи хибності якогось положення за допомогою аргументів, побудованих відповідно Ао правих семантики, синтактики і прагматики, а також з урахуванням правової сфери застосування. Кінцевим продуктом аргументативного мовцення $€$ аргументативний текст в його 
комунікативних різновидах (текст-обгрунтування, текст-повного спростування тези та текст-часткового спростування тези). Навчання англійського аргументативного письма майбутніх юристів має зАійснюватися віАповіАно Ао ситуацій спілкування, притаманних існуючій юридичній практиці. Ао основних жанрів, які $є$ ефективними Аця навчання англійського аргументативного письма майбутніх правознавців, віАносимо мист-пораду, меморандум, мист-попередження, позовну заяву, мист-віАповіАь на попереАження.

\section{3 Теоретико-методичні аспекти Аистанційного навчання ангхійського аргументативного письма студентів-юристів}

Навчання англійського аргументативного письма студентівюристів - це скмаАний і тривалий процес, який спонукає нас Ао пошуку нових ефективних методик, які 6 забезпечими Аосягнення максимального результату з мінімальними ресурсними затратами. У світлі стрімкого розвитку інформаційно-комунікаційних технологій особливого значення набуває Аистанційне навчання, яке, на наш погляА, зАатне вирішити поставмені завдання щодо оптимізації процесу навчання англійського аргументативного письма і створює низку переваг піА час оволодіння знаннями, уміннями і навичками аргументативного писемного мовцення студентами-юристами.

Аистанційне навчання має свою Аовгу історію, пройшло кілька етапів і продовжує розвиватися, оперативно реагуючи на потреби суспільства та вміло використовуючи нові можиивості, які з'явцяються 3 появою новітніх технологій. Як зазначає О.М. Хара: «Аистанційне навчання не скасовує 
фунАаментального принципу АиАактики - «мюАина вчить Аюдину», однак принципово змінює його реацізацію і значно розширює можмивості одержання нових знань» ${ }^{93}$.

Спеціальні наукові Аослідження, присвячені проблемі Аистанційної освіти та іï впровадження в навчальний процес, Аемонструють всебічний інтерес зарубіжних і вітчизняних вчених Ао Ааної проблематики та слугують грунтовною теоретичною базою Аля цієї АосліАницької роботи. Теоретичні основи Аистанційного навчання АосліАжувалися Т. Андерсоном $(\text { T.Anderson })^{94}$, A.A.Андреєвим ${ }^{95},{ }^{96},{ }^{97}$, А.В.Бейтсом (A.W.Bates) ${ }^{98}$, В.Ю. Биковим ${ }^{99},{ }^{100}$, А.Г. Гавріковою ${ }^{101}$, І.В. Герасименко ${ }^{102}$,

93 Хара О. М. Аистанційне навчання математики абітурієнтів у системі довузівської підготовки: автореф. Аис. ... канА. пеА. наук: 13.00.02; КПУ ім. М. П. Арагоманова. Київ, 2010. С. 2.

94 Anderson T. Theory and practice of online learning. Athabasca University, 2004. 454 p.

95 Андреев А. А. Аидактические основы Аистанционного обучения в высших учебных заведениях: Аис. ... Аокт. пеА. наук: 13.00.08. Москва: РАО, 1999. 289 с.

96 Андреев А. А. Солдаткин В. И. Аистанционное обучение: сущность, технология, организация. Москва: ИзАательство МЭСИ, 1999. 196 с.

97 Андрєєв А. А. Введення в Аистанційне навчання: навчально-методичний посібник. Москва: ВУ, 1997.

${ }^{98}$ Bates A. W. Technology, Open Learning and Distance Education. London, Routledge, 1995.

99 Биков В. Ю., Гриценчук О. О., Жук Ю. О. Аистанційне навчання в країнах Європи та США і перспективи Аля України. Інформаційне забезпечення навчально-виховного процесу: інноваційні засоби технології: монографія. Академія пеАагогічних наук України, Інститут засобів навчання. Київ: Атіка, 2005. 252 с.

${ }^{100}$ Биков В. Ю. Моделі організаційних систем відкритої освіти: монографія. Київ: Атіка, 2008. 684 с.

${ }^{101}$ Гаврілова $\Lambda$., Катасонова Ю. Теоретичні аспекти впровадження дистанційного навчання в Україні. Освіто-логічний Аискурс. 2017. № 1-2 (16-17). С. 168-182.

${ }^{102}$ Герасименко I. В., Садовий А. І., Бікан Н. С. Використання системи Аистанційного навчання на базі Moodle Аһя Аоуніверситетської піАготовки. I Всеукраїнська науково-практична конференція «Moodle Moot Ukraine 2013. Теорія і практика використання системи управміння навчанням Moodle». (м. Київ, 30-31 травня 2013 р.): тези Аоповідей. Київ: КНУБА, 2013. 


\section{M. Аугіамасом (M. Dougiamas) ${ }^{103}$, Заярною I.C. ${ }^{104}, 105$, В.Г. Креме- нем $^{106}$ ， В.М. Кухаренком ${ }^{107},{ }^{108},{ }^{109}$, Н.В. Морзе ${ }^{110}, \quad$ М.Г. Муром (M.G. Moor $)^{111}$, Г.А. Шиліною ${ }^{112}$, Б.І. Шуневичем ${ }^{113}$, О.М. Харою ${ }^{114}$,}

${ }^{103}$ Dougiamas M., Taylor P. C. Improving the effectiveness of tools for Internet-based education. Teaching and Learning Forum 2000, Curtin University of Technology. 2000.

104 Заярна I.C. Аистанційне навчання англійського аргументативного письма стуАентів-правників як преАмет методичного Аослідження . Освіта Аця XXI століття: викмики, проблеми, перспективи: матеріали I міжнародної науково-практичної конференції (29-30 жовтня 2019 року, м. Суми). Суми: ВиА-во СумАПУ імені А.С. Макаренка, 2019. Том 2. C. 5-8.

${ }^{105}$ Zaiarna I. Some Features of Distance Learning of the English Language at Universities. Сучасні тенденції розвитку освіти і науки в інтердисципцінарному контексті: матеріали II-ї Міжнародної науково-практичної конференції, 24-25 березня 2016 р. Редактори-упоряАники: I. Зимомря, В. ІАьницький. Ченстхова; УжгороА; Арогобич: Посвіт, 2016. C. 236-237.

${ }^{106}$ Кремень В. Г. Аистанційна освіта - перспективний шиях розв'язання сучасних проблем розвитку професійної освіти. Вісн. АкаА. Аистанц. освіти. 2003. № 1. С. 4-11.

${ }^{107}$ Кухаренко В. М., Молодих Г. С. Анаціз активності студентів в Аистанційному навчальному курсі. Нові інформаційні технології навчання в навчальних закцадах України: наук. метоА. зб. РеАкол.: I. I. Мархель (гол. реА.) та ін. ОАеса: ОАес. нац. морс. ун-т, 2002. Вип. 9. Ч. 1. 248 с.

${ }^{108}$ Кухаренко В. М., Рибалко О. В., Сиротенко Н. Г. Гнучка розвивацьна Аистанційна система. Наук.-практ. конф., ХНУ, м. Харків, кистопаА, 2001 р. Харків, 2001. С. 69-72.

${ }^{109}$ Kukharenko V. M., Syrotenko N. G. A Competence Forming in a Distance Education. Інтернет-Освіта-Наука-2004: матеріали 4-ї Міжнародної конф. м. Вінниця. Вінниця: Універсум-Вінниця, 2004. С. 67-69.

${ }^{110}$ Морзе Н. В., Аементієвська Н. П. Навчання Аця майбутнього: посіб. Аля вчителів. Київ: ВиАав. група «ВНV», 2005. 420 с.

${ }^{111}$ Moor M. G. \& Kearsley G. Distance Education: A Systems View // Belmont, Wadsworth Publishing Company, 1996.

${ }^{112}$ Шияіна Г. А. Методика Аистанційного навчання української мови учнів основної школи: Аис. ... канА. пеА. наук: 13.00.02; БерАян. Аерж. пеА. ун-т. Київ, 2016. 300 с.

${ }^{113}$ Шуневич Б. І. Розвиток Аистанційного навчання у вищій школі країн Європи та Північної Америки: автореф. Аис. ... А-ра. пеА. наук: 13.00.01; Інститут вищої освіти АкаАемії педагогічних наук України. Київ, 2008. 38 с.

${ }^{114}$ Хара О. М. Аистанційне навчання математики абітурієнтів у системі довузівської підготовки: автореф. Аис. ... канА. пеА. наук: 13.00.02; КПУ ім. М. П. Арагоманова. Київ, 2010. 19 с. 
Б. Холбергом (В. Holmberg) ${ }^{115},{ }^{116}$, М.А. Умрик ${ }^{117}$. Учені вивчали понятійний апарат Аистанційного навчання, особливості Аистанційного навчання у вищій школі та в системі післядипломної освіти, структуру актуальних напрямків Аосліджень проблем Аистанційної професійної освіти, процес реформування заочної освіти в умовах переходу на інноваційні інформаційні технології Аистанційного навчання, тенденції розвитку Аистанційної освіти в контексті глобальної освіти.

Психолого-педагогічним аспектам Аистанційної освіти присвячені результати наукових розвідок П.Г. Асоянц ${ }^{118}$, P. Вегенера (R. Wegener) $)^{119}$, Р. ВАодковського (R. Wlodkowski) $^{120}$, Е.А. Гурової ${ }^{121}, \quad$ С.В. Аобровольської ${ }^{122}$, А. Кроплі (A. Cropley) $)^{123}$, В.I. Овсянникової ${ }^{124}$, Р. Ніколса (R. Nicholls) ${ }^{125}$,

${ }^{115}$ Holmberg B. The Evolution, Principles and Practices of Distance Education. Oldenburg: Bibliotheks und Information system der Universitat Oldenburg, 2005. No 171.

${ }^{116}$ Holmberg B. Theory and Practice of Distance Education. London, Routledge, 1995. Interpretations from an international perspective / Otto Peters. London: Kogan page Limited, 2001. $279 \mathrm{p}$.

117 Умрик М. А. Організація самостійної роботи майбутніх учителів інформатики в умовах Аистанційного навчання інформатичних дисциплін: автореф. Аис. ... канА. пеА. наук: 13.00.02; КПУ ім. М. П. Арагоманова. Київ, 2008. 24 с.

${ }^{118}$ Асоянц П. Г., Чекаль Г. С., Сердюков П. І. Основи методики створення та застосування комп'ютерних програм у навчанні іноземних мов. Київ: КАПІІМ, 2002. 108 с.

${ }^{119}$ Wegener, R. \& Leimeister, J. M.: Virtual Learning Communities: Success Factors and Challenges. International Journal of Technology Enhanced Learning (IJTEL). 2012. Number 5/6. Vol. 4. P. 383-397.

${ }^{120}$ Wlodkowski R. Enhancing adult motivation to learn. San Francisco: Jossey Bass, 1985.

${ }^{121}$ Гуров Е. А. Аистанційна освіта як психолого-педагогічна проблема. Шияхи реформування заочної (Аистанційної) вищої освіти: матеріаци Всеукр. наук.-метоА. конф., 11-13 жовт. 2000 р. Укр. акаА. Арукарства. Київ; Аьвів, 2000. С. 48-49.

${ }^{122}$ Аобровольська С. В. Психолого-пеАагогічні аспекти Аистанційного навчання як засіб модернізації сучасного процесу освіти. Упр. шк. 2004. № 3. С. 27-28.

${ }^{123}$ Cropley A., Kahl T. Distance education and distance learning: Some psychological considerations / Distance Education. 1983. No 4 (1). P. 27-39.

${ }^{124}$ Овсянников В. И. Исследование психолого-педагогических основ Аистанционного образования. Открытое образование. 2004. № 2. С. 7-14.

${ }^{125}$ Nicholls R. The Psychology of the Internet // Psychology of the Future. 2001. № 4. P. 35-52. 
М.^. Смульсон ${ }^{126}$, аналіз яких Аозволив нам сформулювати наступні психологічні особливості Аистанційного навчання англійського аргументативного письма: наявність мотивації студентів Ао зАійснення навчальної Аіяльності (усліА за

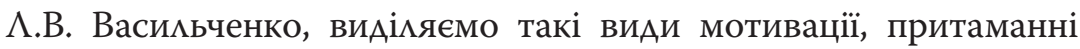
Аистанційній формі навчання, як Аілова, пізнавальна, мотивація співробітництва, самореалізації і розвитку рекреційності, афіляції ${ }^{127}$ ); забезпечення психологічної комфортності навчацьної Аіяльності з урахуванням вікових і психологічних особливостей студентів (гендер, тип темпераменту, типи сприймання інформації, типи сприйняття та узагальнення інформації); врахування соціального компоненту (організація взаємодії між суб'єктами навчання, шляхом створення віртуальної навчальної спільноти). Більш детально психологічні аспекти дистанційного навчання англійського аргументативного письма розгляАалися нами в окремим Аослідження ${ }^{128},{ }^{129}$ та будуть в подальшому враховані піА час розробки АиАактичної моделі Аистанційного навчання англійського аргументативного письма та відображені в метоАичних рекомендаціях щодо зАійснення Аистанційного навчання ангАійського аргументативного письма студентів-юристів.

${ }^{126}$ Аистанційне навчання: психологічні засади: монографія. М. А. Смульсон, Ю. І. Машбиць, М. І. ЖацАак та ін.; за реА. М. $\Lambda$. Смульсон. КіровограА: Імекс- $\Lambda$ ТА, 2012. 240 c.

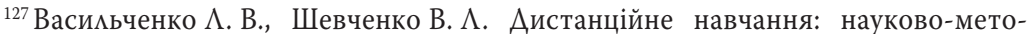
Аичне забезпечення; інформаційний простір навчального закцаду. Харків: Основа, 2009. С. 64.

${ }^{128}$ Заярна I.C. Психологічна комфортність як чинник ефективності Аистанційного навчання англійського аргументованого писемного мовлення студентів-правників. Роль інновацій в трансформації сучасної науки : Матеріали Міжнародної науково-практичної конференції (м. Київ, 29-30 грудня 2017 р.). ГО «Інститут інноваційної освіти»; Науково-навчальний центр прикмадної інформатики НАН України. У 2-х частинах. Київ : ГО «Інститут інноваційної освіти», 2017. ч. 1. С. 21-23.

${ }^{129}$ Zaiarna I. S. Psychological aspects of distance learning of English reasoning writing as a type of law students' learning activity. The unity of science: International scientific professional periodical journal, December, 2017 - January, 2018. Czech Republic, Prague, 2018. P. 27-32. 
Проблема навчально-методичного забезпечення Аистанційного навчання та методологія створення навчальних Аистанційних курсів розгляАалися В.П. АнАрущенком ${ }^{130}$, В.Ю.Биковим ${ }^{131}$, В.В. Вишнівським ${ }^{132}$, Н.В. Жевакіною ${ }^{133}$, Г.О. Козмаковою ${ }^{134}$, T.I. Коробейніковою ${ }^{135}$, В.А. Кравцем ${ }^{136}$, О.О. Нікішовим ${ }^{137}$, O.M. Спіріним ${ }^{138},{ }^{139},{ }^{140}$. Аослідники мають вагомі результати

${ }^{130}$ Анарущенко В. П., Кудін А. П. Реалізація системи безперервної освіти в Націонацьному педагогічному університеті імені М. П. Арагоманова через Аистанційну форму навчання. Вісн. АкаА. Аистанц. освіти. 2003. № 1. С. 49-50.

${ }^{131}$ Bykov V.Yu., Kuharenko V. M., Molodyh A. S. Influence of Learning Process Organization on Students' achievments in Distance Education // Інтернет-Освіта-Наука-2004: матеріали 4-і Міжнародної конф., м. Вінниця, Універсум. Вінниця, 2004. С. 43-45.

${ }^{132}$ Вишнівський В. В., Гніденко М. П., Гайдур Г. І., Іиьїн О. О. Організація Аистанційного навчання. Створення електронних навчальних курсів та електронних тестів: навчамьний посібник. Київ: АУТ, 2014. 140 с.

133 Жевакіна Н. В. Ефективність Аистанційних технологій навчання. Освіта Аонбасу. 2004. № 2. С. 73-78.

${ }^{134}$ Козмакова Г. О. Інформаційно-програмне забезпечення Аистанційної освіти: зарубіжний і вітчизняний досвіА: монографія. АПН України; Ін-т вищ. освіти. Київ, 2002. 231 c.

${ }^{135}$ Коробейнікова Т. І. Сучасні он- аайн сервіси організації самостійної роботи 3 англійської мови Аля майбутніх перекцадачів. Вісник Київського національного мінгвістичного університету. Серія Педагогіка та психологія: зб. наук. праць. К. : КНАУ, 2019. Вип.30. С. 97-102.

${ }^{136}$ Кравец В. А., Кухаренко В. А., Сиротенко Н. Г. Кадровое обеспечение Аистанционного обучения в университете. Информационные технологии в образовании, ИТО 2002: материалы XII МежАунар. конф.-выставка, г. Москва, 4-8 ноября 2002 г. Москва, 2002. С. 63-65.

${ }^{137}$ Никишов А. А., Сюцькова Н. В. Инновационные технологии Аистанционного образования сельского населения: учеб. пособие. Москва: РУАН, 2008. 196 с.

${ }^{138}$ Спірін О. М. Інформаційно-комунікаційні та інформатичні компетентності як компоненти системи професійно-спеціалізованих компетентностей вчителя інформатики // Інформаційні технології і засоби навчання. 2009. 5 (13). URL: file:///C:/Users/\%D0\%9E\%D0\% BB\%D0\%B5\%D0\%B3/Downloads/183-Article\%20Text-535-1-10-20100826.pdf

${ }^{139}$ Спірін О. М., Вакалюк Т. А. Критерії добору відкритих web-орієнтованих технологій навчання основ програмування майбутніх учителів інформатики // Інформаційні техномогії і засоби навчання. 2017. Том 60. № 4. C. 275-287. URL: file:///C:/Users/\%D0\%9E\%D0\% BB\%D0\%B5\%D0\%B3/Downloads/1815-Article\%20Text-7808-1-10-20170929.pdf

${ }^{140}$ Спірін О. М., Колос К. Р. Педагогічний експеримент 3 розвитку предметних компетентностей учителів інформатики засобами Аистанційного навчання // Iнформаційні технології і засоби навчання. 2011. № 5 (25). URL: file:///C:/Users/\%D0\%9E\%D0\% BB\%D0\%B5\%D0\%B3/Downloads/555-Article\%20Text-1762-1-10-20111203.pdf 
щодо методології проектування Аистанційних курсів: випрацьовано процедуру визначення цілей курсу та піАходів до навчання, розроблено структуру та вимоги Ао Аистанційного курсу, вивчені різноманітні інформаційні матеріали Аистанційного курсу та принципи зАійснення контролю піА час Аистанційного навчання. Зокрема, обов'язковими елементами у структурі Аистанційного курсу науковці визначають наступні: «Передмова» - інформаційна сторінка курсу, яка описує мету та загальні відомості про курс (тривалість, обсяг, прогнозовані результати тощо); «Автори курсу» та «Тьютор» - сторінки, які характеризують викладачів як особистостей; «Програма курсу» - сторінка, яка містить основні складові курсу; та «Головна сторінка тижневого заняття» вкцючає назву розАіку, мету, кцючові слова, структурно-логічну схему роздіку, план роботи на тижАень, глосарій та бібліотеку ${ }^{141}$, які і будуть в подальшому вкцючені в авторський курс English Reasoning Writing for Law Students ${ }^{142}$.

Особливий науковий інтерес в межах вивчення метоАики Аистанційного навчання англійського аргументативного письма викАикають роботи вчених-методистів, присвячені особливостям Аистанційного навчання іноземної мови. МетоАика навчання німецького писемного мовлення студентів-заочників вищих мовних навчацьних закмадів на основі використання Аистанційного курсу АосліАжувалася В.П. СвириАюк ${ }^{143}$. Науковцем було вперше обгрунтовано психолого-педагогічні засади застосування Аистанційного навчання іноземної мови

${ }^{141}$ Биков В. Ю., Кухаренко В. М., Сиротенко Н. Г., Рибалко О. В., Богачков Ю. М. Технологія створення Аистанційного курсу: навчальний посібник / за реА. В. Ю. Бикова, В. М. Кухаренка. Київ: Міленіум, 2008. С. 117-118.

142 Заярна I. С. Аистанційний курс English Reasoning Writing for Law Students. URL: https://dl.knu.ua/course/view.php?id=9264.

${ }^{143}$ Свиридюк В. П. Методика навчання німецького писемного мовлення студентів-заочників вищих мовних навчальних закладів на основі використання Аистанційного курсу: автореф. Аис. ... канА. пеА. наук: 13.00.02; КНАУ. Київ, 2007. 19 с. 
студентами-заочниками та розроблено Аистанційний курс Аля навчання написання реферату німецькою мовою. Так, Аос $\mathrm{i}_{\text {A- }}$ ниця розробила структуру Аистанційного курсу з чотирьох блоків (вступний, інформаційно-довідковий, навчальний та контрольний), кожен з яких, у свою чергу, скцадався із декількох модулів, які об'єАнувалися загальною тематикою інформації або навчацьного матеріацу. Вважаємо таку структуру Аистанційного курсу цілком обгрунтованою, аАже нею переАбачені всі структурні елементи навчацьної Аіяльності, опосереАкованої комп'ютером: інформація щодо організації навчального процесу у Аистанційному навчальному середовищі, навчальнометодичний матеріац, система вправ.

Проблема використання Аистанційних технологій Аля самостійного оволоАіння франкомовним Аіловим писемним спілкуванням майбутніми Аокументознавцями стала преАметом вивчення Н.В. Майє ${ }^{144}$, яка теоретично обгрунтуваца особливості використання Аистанційних технологій піА час самостійного оволодіння франкомовним Аіловим писемним мовленням та розробила віАповіАну методику з використанням електронного кейсу (комп'ютерний засіб навчання, який розміщений у мережі Інтернет і містить комплект навчально-методичних матеріалів Аля формування у студентів необхіАних умінь, забезпечує керування їх самостійною навчацьно-пізнавацьною Аіяльністю в позааудиторних умовах).

Особливості формування аргументативних стратегій англійською мовою у магістрів-психологів з використанням мережевих комп'ютерних технологій вивчала Ю.В. Батуріна ${ }^{145}$.

${ }^{144}$ Майєр Н. В. Методика самостійного оволодіння франкомовним діловим писемним спілкуванням майбутніми Аокументознавцями з використанням Аистанційних технологій: Аис. ... канА. пеА. наук: спец. 13.00.02. Київ, 2011. 286 с.

${ }^{145}$ Батурина Ю. В. Формирование аргументативных стратегий у магистрантов-психологов с использованием сетевых компьютерных технологий: на материале английского языка: Аис. ... канА. пеА. наук: 13.00.02; Санкт-Петербургский гос. ун-т. Санкт-Петербург, 2015. 275 с. 
Аослідницею обгрунтована необхідність розробки нових форм та методів активізації самостійної Аіяльності магістрів-психомогів шляхом використання мережевих комп'ютерних ресурсів та вивчений дидактичний потенціал мережевих комп'ютерних технологій, які використовуються піА час навчання аргументативних стратегій.

Викмикає науковий інтерес наукова праця Г.Р. Біккумової ${ }^{146}$, присвячена методиці Аистанційного формування іншомовної комунікативної компетенції студентів природничого напрямку. Вченою проаналізований зарубіжний досвіА організації Аистанційного навчання іноземній мові, АосліАжені АиАактичні принципи реалізації Аистанційного навчання, його методичні та технологічні аспекти, на основі чого розроблена модель Аистанційного формування іншомовної комунікативної компетенції стуАентів.

Проблему інтеграції Аенної та Аистанційної форм навчання піА час вивчення англійської мови Аосліджувала О.В. Бутенкова ${ }^{147}$. Ученою були вивчені програмні засоби Аистанційного навчання іноземній мові, проаналізовано поняття ресурсного центру, розроблені вимоги Аля створення інтегрованого курсу Аля Аистанційного навчання англійської мови.

Грунтовні наукові розвіАки науковців відображені в законоАавчій базі та свідчать про цілеспрямовану Аержавну політику України щодо інформатизації освіти. На Ааний момент різні аспекти Аистанційної освіти в Україні регулюються наступними нормативних документами: «Про національну доктрину

${ }^{146}$ Бикулова Г. Р. Методика Аистанционного формирования коммуникативной компетенции студентов естественных факультетов университета: на материале английского языка 13.00.02. Санкт-Петербург, 2008. 239 с.

${ }^{147}$ Бутенкова Е. В. Интеграция очной и Аистанционной форм обучения иностранному языку в старших классах общеобразовательной школы: филологический профиль, на материале английского языка: Аис. ... канА. пеА. наук: 13.00.02. Москва, 2007. 270 c. 
розвитку освіти» ${ }^{148}$, «Концепція розвитку Аистанційної освіти в Україні» ${ }^{149}$, «Національна програма інформатизації» ${ }^{150}$, закони України «Про освіту» ${ }^{151}$, «Про вищу освіту» ${ }^{152}$, наказ Міністерства освіти і науки України «Про затверАження Положення про Аистанційне навчання» ${ }^{153}$.

Таким чином, проведений аналіз наукових, начально-метоАичних та нормативних Ажерел, присвячених Аистанційному навчанню, Аозволяє зробити наступні висновки. По-перше, грунтовна законодавча база свідчить про жвавий інтерес Аержави Ао розвитку Аистанційної освіти в Україні та створює правові передумови Аля практичного впроваАження Аистанційних технологій у навчальний процес. Крім того, науковцям вАалося закласти теоретичні засаАи Аистанційного навчання, вивчити його понятійний апарат, АиАактичні та психологічні особливості процесу навчання, розробити методологію створення навчальних Аистанційних курсів. Варто також зазначити, що вченими-методистами були АосліАженні Аеякі особливості Аистанційного навчання іноземної мови, зокрема проблеми навчання іншомовного писемного мовлення та аргументації засобами Аистанційної освіти. Разом 3 тим, незважаючи на існуючі наукові зАобутки, питання Аистанційного навчання

${ }^{148}$ Про Національну Аоктрину розвитку освіти: Указ Президента України віА 17.04.2002 № 347/2002. Офіційний вісник України. 2002. № 16. С. 11.

${ }^{149}$ Концепція розвитку Аистанційної освіти в Україні. URL: http://www.osvita.org.ua/ distance/pravo/00.html.

${ }^{150}$ Про Національну програму інформатизації: Закон України віА 04.02.1998 № 74/98-ВР. Офіційний вісник України. 1998. № 10. С. 5.

${ }^{151}$ Про освіту: Закон України віА 05.09.2017 № 2145-VIII. Урядовий кур'єр. 2017. № 186. № 148 .

${ }^{152}$ Про вищу освіту: Закон України віА 01.07.2014 № 1556-VII. Гомос України. 2014.

${ }^{153}$ Про затверАження Положення про Аистанційне навчання: наказ МОН України віА 25.04.2013 № 466. Урядовий кур’єр. 2013. № 155. 
ангАійського аргументативного писемного мовцення студентівюристів не було преАметом грунтовного вивчення і вимагає спеціального Аослідження.

Розглянемо виАи Аистанційного значення 3 метою визначення найбільш ефективного в межах навчання англійського аргументативного письма. УсліА за В.Ю. Биковим ${ }^{154}$, ми будемо виокремлювати традиційне Аистанційне навчання та електронне Аистанційне навчання, які розрізняються залежно віА характеру організації навчальних комунікацій між учасниками навчального процесу та способу побудови комунікаційного каналу навчального сереАовища (транспортної системи Аоставки навчальних об’єктів). Погоджуємося 3 А. Гавріловою та Ю. Катасоновою, що найточніше сутність сучасного Аистанційного навчання у закмаді вищої освіти «відтворює категорія е-Аистанційного навчання, яке забезпечується використанням ресурсів мережі Інтернет, мультимедійних навчальних засобів та інших електронних освітніх ресурсів» ${ }^{155}$. ПідтверАженням позиції науковців знаходимо у визначенні «дистанційного навчання», зазначеного в чинному Положенні про Аистанційне навчання та затвердженого Наказом Міністерства освіти і науки України віА 25.04.2013 № 466, де законодавець встановлює, що Аистанційне навчання як процес набуття знань, умінь, навичок і способів пізнавальної Аіяльності мюдини відбувається за опосередкованої взаємодії віААалених оАин віА оАного учасників навчального процесу у спеціалізованому середовищі, яке функціонує на базі сучасних інформаційно-комунікаційних технологій ${ }^{156}$. Таким чином, навчання

${ }^{154}$ Биков В. Ю. Аистанційна навчання. Енцикцопедія освіти України. Акад. пеА. наук України; головний реА. В. Г. Кремень. Київ: Юрінком Інтер, 2008. С. 191.

155 Гаврілова $\Lambda$., Катасонова Ю. Теоретичні аспекти впровадження дистанційного навчання в Україні. Освіто- оггічний Аискурс. 2017. № 1-2 (16-17). С. 177.

${ }^{156}$ Про затверАження Положення про Аистанційне навчання: наказ МОН України віА 25.04.2013 № 466. УряАовий кур’єр. 2013. № 155. 
англійського аргументативного письма студентів-юристів вважаємо Аоцільним зАійснювати засобами електронного Аистанційного навчання, які Аозволяють учасникам і організаторам навчального процесу зАійснювати «переважно індивідуаАізовану взаємодію як асинхронно, так і синхронно у часі, переважно і принципово використовуючи електронні транспортні системи Аоставки засобів навчання та інших інформаційних об'єктів, комп'ютерні мережі Інтернет, медіа навча^ьні засоби та інформаційно-комунікаційні технології» ${ }^{157}$.

3'ясувавши характер організації навчальних комунікацій та способу побудови комунікаційного канацу піА час Аистанційного навчання англійського аргументативного письма, на Ааному етапі досліАження вбачаємо за необхідне систематизувати погляди науковців щодо визначення поняття "Аистанційне навчання» та окреслити авторське розуміння в межах вивчення зазначеної проблеми. Варто зауважити, що стрімкий розвиток інформаційно-комунікаційних технологій та різноманіття піАходів у світі до Аистанційного навчання обумовАюють велику кількість визначень цього поняття. СклаАнощі у розумінні поняття обумовцені і значним розширенням термінологічної мексики, пов'язаної з Аистанційним навчанням, особливо в розумінні англійських термінів, котрі мають широкий синонімічний ряА: distance education, distance learning, e-learning (eLearning, electronic learning), online learning (on-line learning), blended learning, virtual learning, Internet-based learning, Internet-based training, Web-based learning, Web-based training, open learning, open and distance learning та інші.

Учені М. Роблер (M. Roblyer) та Аж. ЕАварАс (J. Edwards) у своєму Аослідження «Інтеграція освітніх технологій в навчання» наводять таке визначення електронного Аистан-

${ }^{157}$ Биков В. Ю. Аистанційна навчання. Енцикцопедія освіти України. АкаА. пеА. наук України; головний реА. В. Г. Кремень. Київ: Юрінком Інтер, 2008. С. 191. 
ційного навчання: набуття знань та навичок шияхом опосереАкованого навчання, що охоплює всі технології та інші форми навчання на відстані. На думку науковців, дистанційне навчання передбачає навчання за рахунок використання телекомунікаційних технологій, які переАають і отримують численні матеріали через голос, відео та Аані ${ }^{158}$.

Схоже розуміння Ааного поняття Аемонструє Є.С. Полат, визначаючи Аистанційне навчання як систему навчання, засновану на взаємодії вчителя та учнів, учнів між собою на відстані, що відображає всі притаманні навчацьному процесу компоненти (цілі, зміст, організаційні форми, засоби навчання) специфічними засобами інформаційно-комунікаційних технологій та Інтернет-технологіями ${ }^{159}$.

Аля М. Mypa (M. Moore) і Г. Кірслі (G. Kearsley) Аистанційне навчання - це заплановане навчання, яке зазвичай віАбувається в іншому місці віА викмадання i, як наслідок, вимагає спеціальних методів проектування курсу, спеціальних метоАичних прийомів, спеціальних методів комунікації з допомогою електронних та інших технологій, а також організаційних та аАміністративних заходів ${ }^{160}$.

Німецький досліАник P.M. Аем інг (R.M. Delling) вважає, що Аистанційне навчання $\epsilon$ плановою систематичною Аіяльністю, що включає в себе вибір, Аидактичну підготовку та забезпечення навчальним матеріалом, а також моніторинг і підтримку студентів, які досягаються шляхом подолання фізичної відстані

${ }^{158}$ Roblyer, M. D., \& Edwards, J. Integrating educational technology into teaching. 2nd ed. Upper Saddle River. New Jersey: Merrill, 20006 P. 192.

${ }^{159}$ Полат Е. С., Бухаркина М. Ю., Моисеева В. М., Петров А. Е. Современные педагогические и информационные технологии в системе образования: учеб. пособие Аля стуА. пеА. вузов и системы повыш. квалиф. пеА. кадров; под реА. Е. С. Полат. 4-е изА., стер. Москва: ИзАательский центр «Академия», 2009. 272 с.

${ }^{160}$ Moor M. G. \& Kearsley G. Distance Education: A Systems View. Belmont, Wadsworth Publishing Company, 1996, P. 1-2. 
між студентом і викладачем за Аопомогою принаймні одного технічного телекомунікаційного засобу ${ }^{161}$.

Узагальнення наведених дефініцій демонструє змістовну близькість Аоктринальних позицій вітчизняних і зарубіжних АосліАників щодо розуміння сутності поняття Аистанційного навчання та Аозволяє нам сформулювати визначення Аистанційного навчання в межах цієї АосліАницької роботи. Отже, Аистанційне навчання ангАійського аргументативного письма розуміємо як пианову системну Аіямьність, яка характеризується відокремменістю у просторі і часі учасників навчального процесу, наявністю спеціальних метоАичних прийомів, комунікаційних, організаційних та аАміністративних заходів, та зАійснюеться новітніми технічними засобами навчання 3 метою формування умінь англійського аргументативного письма.

На основі сформульованого визначення можна виАілити ознаки дистанційного навчання англійського аргументативного письма, які розкривають його сутність та зміст:

- планова системна Аіяльність відображає притаманні навчальному процесу компоненти (цілі, зміст, організаційні форми, засоби навчання);

- відокремленість у просторі і часі студента і викладача, а також студентів між собою;

- використання різноманітних ресурсів і новітніх технічних засобів навчання (навчання зАійснюється засобами інформаційно-комунікаційних технологій та Інтернет-технологіями) Аля оволодіння уміннями в ангАійському аргументативному письмі;

- наявність спеціальних методичних, комунікаційних, організаційних та аАміністративних заходів, спрямо-

${ }^{161}$ Delling R. M. Towards a theory of distance education. ICDE Bulletin 13, 1987. P. 21-25. 
ваних на оволодіння умінь в ангційському аргументативному письмі.

УсміА за В.Ю. Биковим ${ }^{162}$, визначаємо такі специфічні якісні вАастивості Аистанційного навчання ангАійського аргументативного письма: гнучкість і адаптованість навчального процесу до потреб і можливостей майбутніх правознавиів, що Аозволяє останнім навчатися у зручний Аля себе час та у віАповіАності Ао індивіАуамьних можАивостей (стан зАоров'я, соціацьний статус, тощо); модульність побудови навчальних програм, покмадена в основу Аистанційного навчання ангмійського аргументативного письма, Аозвоцяє нам сформувати навчацьну програму, яка враховує особливості навчання іншомовного аргументативного мовцення, Ае кожен модуль присвячений окремому жанру англійського аргументативного письма; зміна ролі викладача, основними функціями якого $\epsilon$ коорАинація навчально-пізнавацьного процесу, коригування курсу, який викмаАається, керівництво навчацьними проектами, консумьтування навчальними групами взаємопіАтримки та ін.; сnеціальні борми контролю якості навчальних досягнень в оволодіння уміннями в англійському аргументативному письмі передбачають роботу в середовищі комп'ютерних інтелектуальних тестових систем, що Аозвоцяє стуАентам-юристам отримувати миттєвий зворотній зв'язок; використання базових $i$ спечіалізованих комунікативних технологій підтримки взаємодї суб'єктів процесу дистанційного навчання англійського аргументативного письма, визначальною технологічною манкою яких $\epsilon$ технології телекомунікацій та їх транспортна основа; викорисмання спеціалізованих засобів навчання та борм організації навчальної діяльності, зокрема, таких як спрямоване навчання,

${ }^{162}$ Биков В. Ю. Аистанційна навчання. Енцикцопедія освіти України. АкаА. пеА. наук України; головний ред. В. Г. Кремень. Київ: Юрінком Інтер, 2008. С. 191-193. 
орієнтоване на самоосвіту учня та кероване навчання, яке зАійснюється піА керівництвом тьютора.

Грунтовного вивчення в межах цієї монографічної роботи вимагає питання вибору онлайн технологій, які віАповіАають меті та завАанням Аистанційного навчання англійського аргументативного письма майбутніх правознавців та зАатні реалізувати характерні принципи, піАходи та методи навчання.

Аоступні на сьогодні онлайн технології можна поділити на Аві категорії: технології віАкритого доступу (Open technologies) та системи керування навчанням (Institutionally supported technologies aбo Learning Management System) ${ }^{163}$.

Технології віАкритого Аоступу, які також часто називають Web 2.0 або соціальні меАіа, створені задля реалізації конкретної функції або завдання. Їх безумовною перевагою $€$ Аегкість встановлення і використання, а також доступність (зазвичай вони $є$ безкоштовними, а за невисоку оплату пропонують Аодаткові опції). Прикмади таких технологій численні i вкцючають, хоча не обмежені, наступними сервісами: YouTube, Facebook, Wordpress, Flickr, Blogger та інші. Разом з тим, розпорошеність та доступність мережевих сервісів, їхня ізольованість віА навчального закцаАу, а також віАсутність сервісної технічної піАтримки породжують перенасичення відомостями і даними в інформаційному просторі. Це призводить Ао марнування цінного часу та власних зусиль на пошуки необхіАної інформації, тим самим змушуючи науковців і практиків шукати нові можливості в Інтернеті, зАатні систематизувати існуючі технології на оАній платформі. Таким рішенням стали системи керування навчанням.

163 Заярна I. С. Особливості навчання англійського аргументованого писемного мовлення студентів-юристів засобами дистанційного навчання. Вісник Кременчуцького національного університету імені Михайла Остроградського. Педагогічні науки, 2018. № 2/201 (109). С. 38. (C. 35-44). 
Система керування навчанням, також відома як віртуальне навчальне середовище, - це централізована закрита система, безпека якої гарантується шияхом встановцення автентичності кожного учасника навчального процесу, а доступ надається

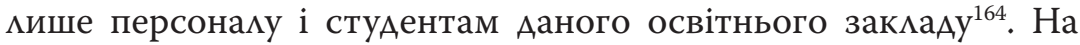
віАміну віА технологій віАкритого Аоступу, які націлені на виконання якоїсь однієї функції чи завдання, система керування навчання пропонує широкий спектр сервісів, таких як обговорення у форумах, блоги, вікі, виконання завдань та інші. Система керування навчанням надає можливість вести журнали оцінювання успіхів студенів та включає інструменти адміністрування системою, які Аозволяють викмадачеві користуватися функціями у віАповіАності до навчальних цілей і потреб. Прикладами таких систем $€$ Blackboard, Moodle, Google Classroom та інші.

Ао основних переваг системи керування навчанням науковці віАносять: централізованість (всі компоненти віртуального кмасу зосереджені на одному захищеному сервісі); захищеність (Аоступ Ао віртуального кмасу захищений паромем, що Аозволяє створити безпечне та контрольоване сереАовище та унеможмивить Аоступ сторонніх користувачів); відстеження та зіставлення (системи керування навчанням надають викцаАачеві можливість спостерігати процес виконання завАань, Аоступні статистичні дані успішності студентів, а також можАивість синхронізувати виставлення балів на сервісі і в навчальному закмаді); збереження даних (система керування навчанням надає можмивість зберігати всі дані протягом кількох років) ${ }^{165}$.

У межах нашого АосліАження ми розглянемо можиивості використання платформи Moodle Аля Аистанційного навчання

${ }^{164}$ Learning to Teach Online. Open and institutionally supported technologies. URL: http://bit.ly/coursera-ltto.

165 Там само. 
ангАійського аргументативного письма студентам юридичного профілю. Технічні можливості цієї системи, її доступність, архітектура та закладені принципи роблять платформу Moodle (Modular Object Oriented Dictance Learning Environment) надзвичайно попукярною та затребуваною сереА користувачів в більше ніж 175 країнах світу. Як зазначають у своїй праці В.В. Вишнівський, М.П. Гніденко, Г.І. Гайдур, О.О. І Аене порівняльне дослідження дев'яти платформ Аля організації електронного Аистанційного навчання (Moodle, ILIAS, Dokeos, A Tutor, LON-CAPA, Sakai, OpenUSS, Spaghettilearning, dotLRN) за 34 параметрами, Аозволило виокремити систему керування навчанням Moodle як беззаперечного Аідера на світовому ринку Аистанційних освітніх послуг.

Перекониивим свідченням ефективності роботи Moodle $\epsilon$ вагомі результати численних наукових Аосліджень вітчизняних i зарубіжних вчених, присвячених особливостям Аистанційного навчання на платформі Moodle. Теоретичні та організаційно-методичні засади використання платформи Moodle піА час Аистанційного навчацьного процесу були преАметом спеціальних наукових розвідок А.В. Андрєєва ${ }^{167}$, О.С. Бескорсої ${ }^{168}, \quad$ Н.M. Болюбаш ${ }^{169}, \quad$ В.C. Ву $\quad(W . S . ~ W u)^{170}$,

${ }^{166}$ Вишнівський В. В., Гніденко М. П., Гайдур Г. І., Іцьїн О. О. Організація Аистанційного навчання. Створення електронних навчальних курсів та електронних тестів: навчальний посібник. Київ: АУТ, 2014. 140 с.

${ }^{167}$ Андреев А. В., Анареева С. В., Аоценко И. Б. Практика экектронного обучения с использованием Moodle. Таганрог: ИзА-во ТТИ ЮФУ, 2008. 146 с.

${ }^{168}$ Бескорса О. С. Система Moodle як засіб організації змішаного навчання практичної фонетики німецької мови. Інформаційні технології і засоби навчання. 2017. Том 62. № 6. URL: file://C:/Users/\%D0\%9E\%D0\%BB\%D0\%B5\%D0\%B3/Downloads/1832-8577-1-PB\%20(1).pdf.

${ }^{169}$ Болюбаш Н. М. Організаційно-методичні аспекти навчання на базі інформаційного середовища Moodle. Інформаційні технології і засоби навчання. 2013. № 1 (33). URL: file://C:/Users/\%D0\%9E\%D0\%BB\%D0\%B5\%D0\%B3/Downloads/761-2611-1-PB\%20(1).pdf.

${ }^{170} \mathrm{Wu}$ W.-Sh. The application of Moodle on an EFL collegiate writing environment. Journal of Education and Foreign Languages and Literature. 2008. June. V. 7. P. 45-56. 


\section{I.В. Герасименко ${ }^{171},{ }^{172}, \quad$ M. Аугіамас $\quad$ (M. Dougiamas $)^{173},{ }^{174}$,

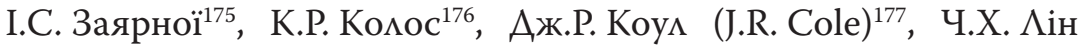 (Ch.-H. Lin $)^{178}$, Я.В. Окопної ${ }^{179}$, С.В. Петренка ${ }^{180}$, В.Х. Райс}

${ }^{171}$ Герасименко I. В., Садовий А. І., Білан Н. С. Використання системи дистанційного навчання на базі Moodle Аля Аоуніверситетської піАготовки. I Всеукраїнська науково-практична конференція «Moodle Moot Ukraine 2013. Теорія і практика використання системи управління навчанням Moodle». (м. Київ, 30-31 травня 2013 р.): тези Аоповідей. Київ: КНУБА, 2013.

${ }^{172}$ Герасименко I. В. Створення навчального курсу в системі електронного навчання на базі Moodle. Педагогічний ацьманах: зб. наук. пр. Редкоц.: В. В. Кузьменко (голова) та ін. Херсон: КВНЗ «Херсонська академія неперервної освіти», 2012. Випуск 16. C. $109-115$.

${ }^{173}$ Dougiamas M., Taylor P. C. Interpretive analysis of an internet-based course constructed using a new courseware tool called Moodle. Proceedings of the Higher Education Research and Development Society of Australasia (HERDSA) 2002 Conference, Perth, Western Australia. 2002.

${ }^{174}$ Dougiamas M. and Taylor P. C. Moodle: Using Learning Communities to Create an Open Source Course Management System. Proceedings of the EDMEDIA. Conference, Honolulu, Hawaii. 2003.

${ }^{175}$ Заярна I.C. Особливості Аистанційного навчання англійського юридичного аргументованого писемного мовцення на платформі Moodle. Актуальні питання державотворення в Україні: матеріали Міжнародної науково-практичної конференції (19 травня 2017 року). Редкол.: А.ю.н. І. С. Гриценко (голова), к.ю.н. І. С. Сахарук (віАп. реА.) та ін. В 2-х томах. Том 2. К.: ВПЦ «Київський університет», 2017. С. 401-402.

${ }^{176}$ Колос К. Р. Система Moodle як засіб розвитку предметних компетентностей учителів інформатики в умовах Аистанційної післядипломної освіти: Аис. канА. пеА. наук: 13.00.10; Житом. Аерж. ун-т. ім. І. Франка. Житомир, 2011. 238 с.

${ }^{177}$ Cole Jason R. Using Moodle: teaching with the popular open source course management system. Sebastopol, California: O’Reilly Community Press, 2005. 219 p.

${ }^{178}$ Lin Ch.-H. Using Moodle in a General Education English as a Second Language Program: Taiwanese College Student Experiences and Perspectives. Journal of Educational and Social Research MCSER Publishing. Rome-Italy, 2013. Vol. 3. No. 3. P. 97-104.

${ }^{179}$ Окопна Я.В. Система Moodle в Аистанційному професійно орієнтованому навчанні Аругої іноземної мови майбутніх працівників туристичної сфери: мережева підтримка навчально-виховного процесу. URL: http://enpuir.npu.edu.ua/bitstream/123456789/9623/1/Okopna.pdf

${ }^{180}$ Петренко С. В. Оптимізація й анаціз результатів використання LMS MOODLE y системі змішаного навчання в університеті. Інформаційні технології і засоби навчання. 2017. Том 61 (№ 5). С. 140-150. 
(W.H. Rice) $)^{181}$, К.В. Руаніцької ${ }^{182}, \quad$ Є.M. Смирнової-Трибульської 183 Ю.В. Триуса ${ }^{184}$, Г.А. Шиміної ${ }^{185}$.

Проведений нами аналіз наукових Ажерел Аозволяє сформулювати наступні положення, якими ми будемо керуватися піА час Аистанційного навчання ангАійського аргументативного письма студентів-юристів на платформі Moodle.

Організація та управління навчанням зАійснюється засобами аАміністративних інструментів системи. За допомогою таких сервісів як Журнал оцінок, Результати та Статистика, викладач знає не мише коли студенти завершили роботу чи завантажили в систему завдання, але і скільки часу вони витратили на його виконання (рис. 1.3.1). Успішність виконання завдання також демонструють вбудовані Аіаграми, які автоматично порівнюють та узагацьнюють результати по кожному окремому завданню (рис. 1.3.2).

ПреАставцення нового матеріалу та оцінювання результатів навчання реалізується такими навчальними інструментами платформи Moodle як Урок, Завдання, Глосарій, Анкета, Тести,

${ }^{181}$ Rice I., William H. Moodle E-Learning Course Development: a complete guide to successful learning using Moodle. Birmingham: Packet Publishing, 2006. $236 \mathrm{p}$.

${ }^{182}$ Рудніцька К. В. Сутність понять «компетентнісний піАхіА», «компетентність», «компетенція», «професійна компетентність» у світлі сучасної освітньої парадигми. Науковий вісник Ужгородського університету. 2016. Серія: «ПеАагогіка. Соціальна робота». Випуск 1 (38). С. 241-244.

${ }^{183}$ Смирнова-Трибульска Є. М. Аистанційне навчання з використанням системи Moodle: навчацьно-методичний посібник. Херсон: Айлант, 2007. 492 с.

${ }^{184}$ Триус Ю. В., Герасименко І. В., Франчук В. М. Система електронного навчання BН3 на базі Moodle: Методичний посібник. За реА. Ю. В. Триуса, Ю. А. Чабаненко. Черкаси, 2012. 220 с.

${ }^{185}$ Шиліна Г. А. Забезпечення Аопрофільного вивчення української мови в сучасній середній школі засобами Аистанційного навчання в системі Moodle. Щорічний науковий збірник Четвертої Міжнародної наукової Інтернет-конференції з україністики. УпоряА. О. Новікова. Мюнхен-Берлін. 2014. Випуск 13. C. 603-611. 


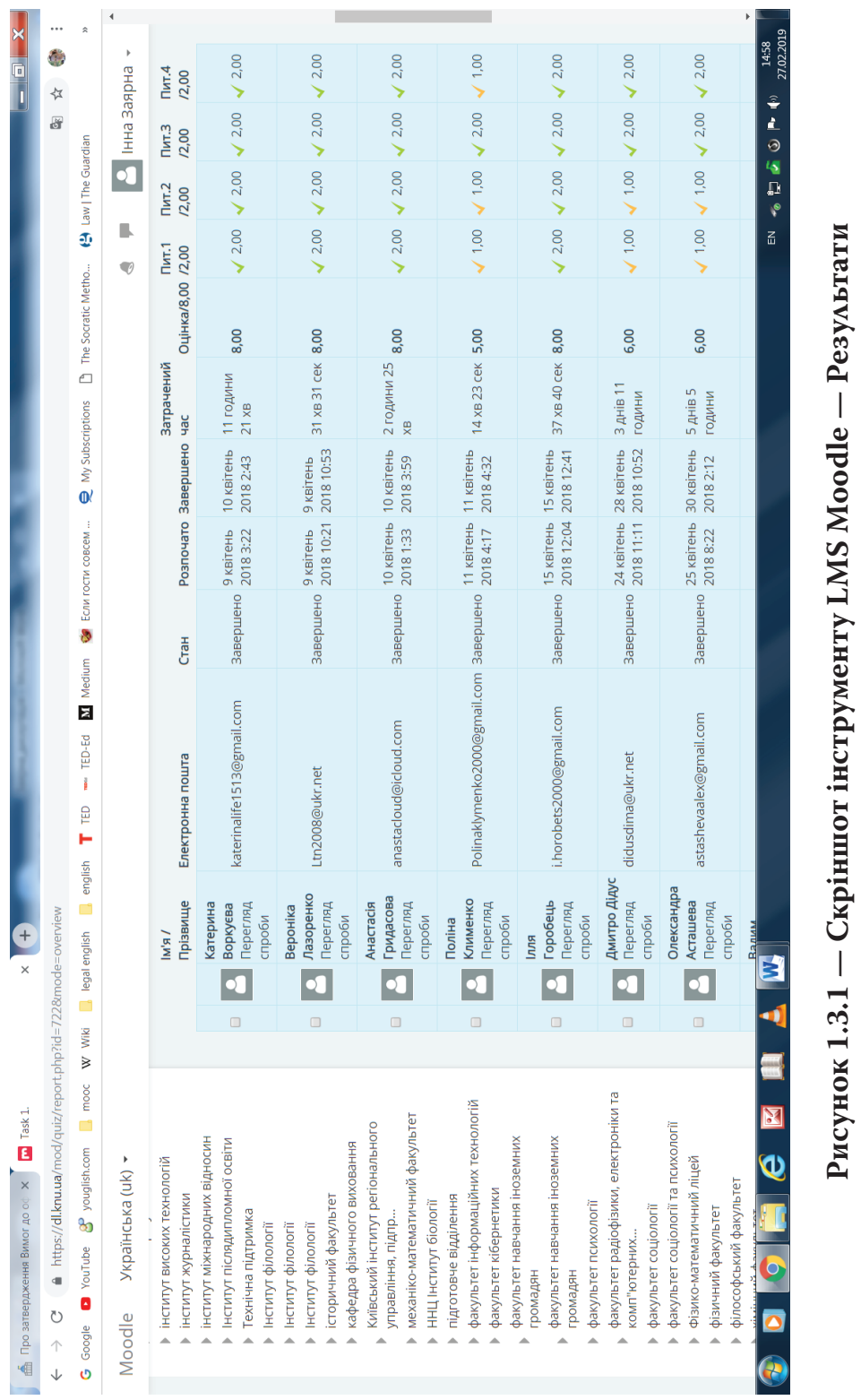




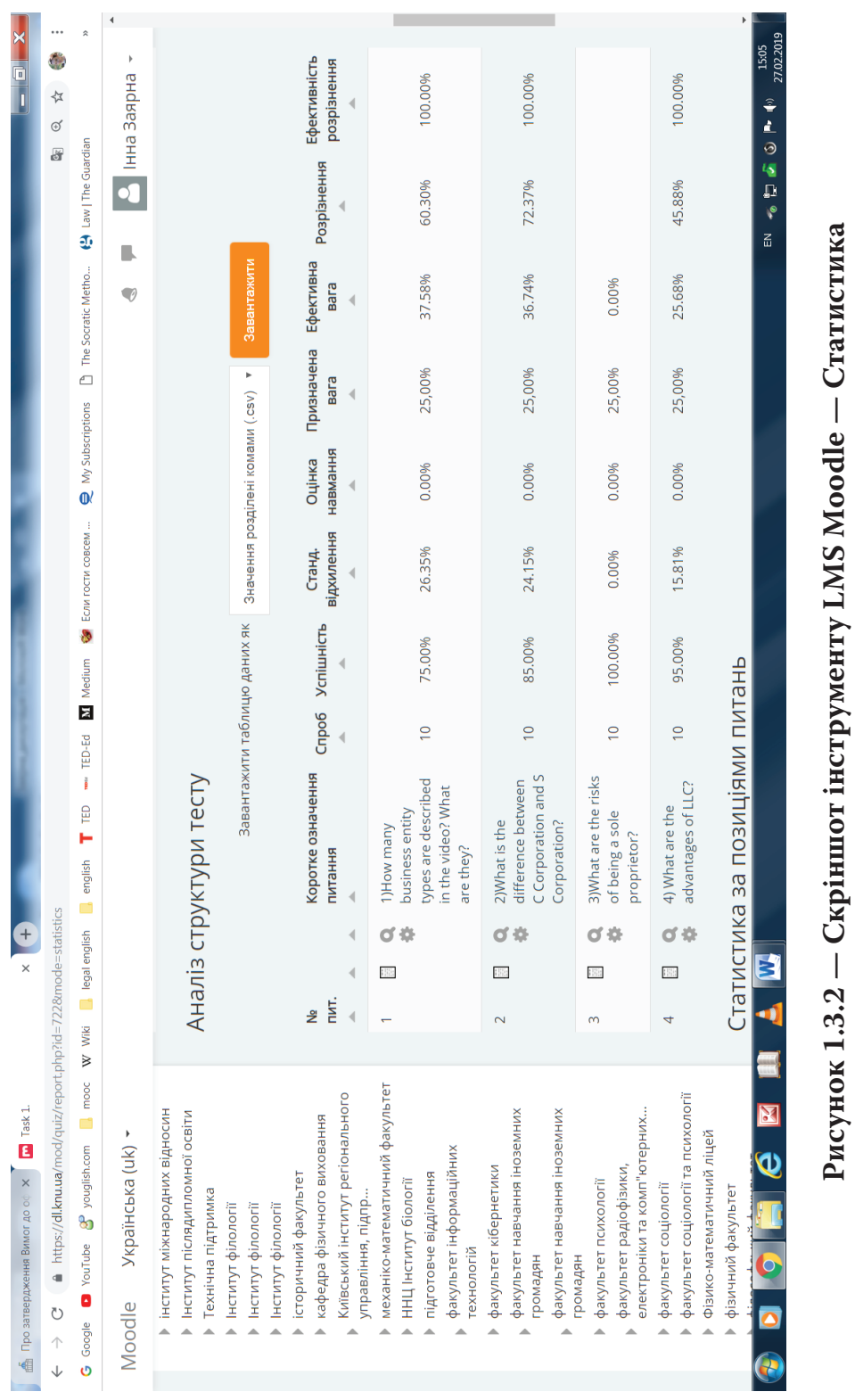


Семінар, Опитування. ВикцаАач має можиивість презентувати навчальний матеріал у цікавій та гнучкій формі в електронному вигляді у будь-якому форматі, перевірити рівень засвоєння пройденого матеріалу, прокоментувати та оцінити роботи студентів. Викладач сам встановлює кінцеві терміни зАачі завдання та часові рамки на його виконання, визначає кількість спроб та можиивість перескцадання. Проілюструємо Аеякі 3 навчальних інструментів LMS Moodle на рисунках (рис. 1.3.3 та рис. 1.3.4):

Вагомою перевагою пиатформи Moodle $€$ можмивість кооперативного навчання завдяки таким комунікативним інструментам як Wiki (рис. 1.3.11), Форум, Чат, Блог, Семінар. В межах цих сервісів $\epsilon$ можмивість організувати спільну роботу студентів, поділити їх на піАгрупи і працювати як у синхронному, так і асинхронному режимах. Усі записи і діалоги зберігаються в пам'яті системи і доступні Аля подальшого анацізу та оцінки. На рис. 1.3.5 та рис. 1.3.6 зображені приклади використання комунікативних інструментів LMS Moodle:

ПіАсумовуючи вищевикмадене, можна стверАжувати, що процес навчання англійського аргументативного письма на базі системи керування навчанням Moodle Аозволяє ефективно реалізовувати цілі та завдання навчання англійського аргументативного письма завАяки вбудованим інструментам та закладеним принципам, які зАатні забезпечити як індивіАуальне, так і спільне навчання.

Розглянувши сутність Аистанційного навчання англійського аргументативного письма, звернемося до визначення кмючових піАходів, принципів та методів навчання, які скмаАають методичну основу Аля формування віАповіАних комунікативних умінь. 


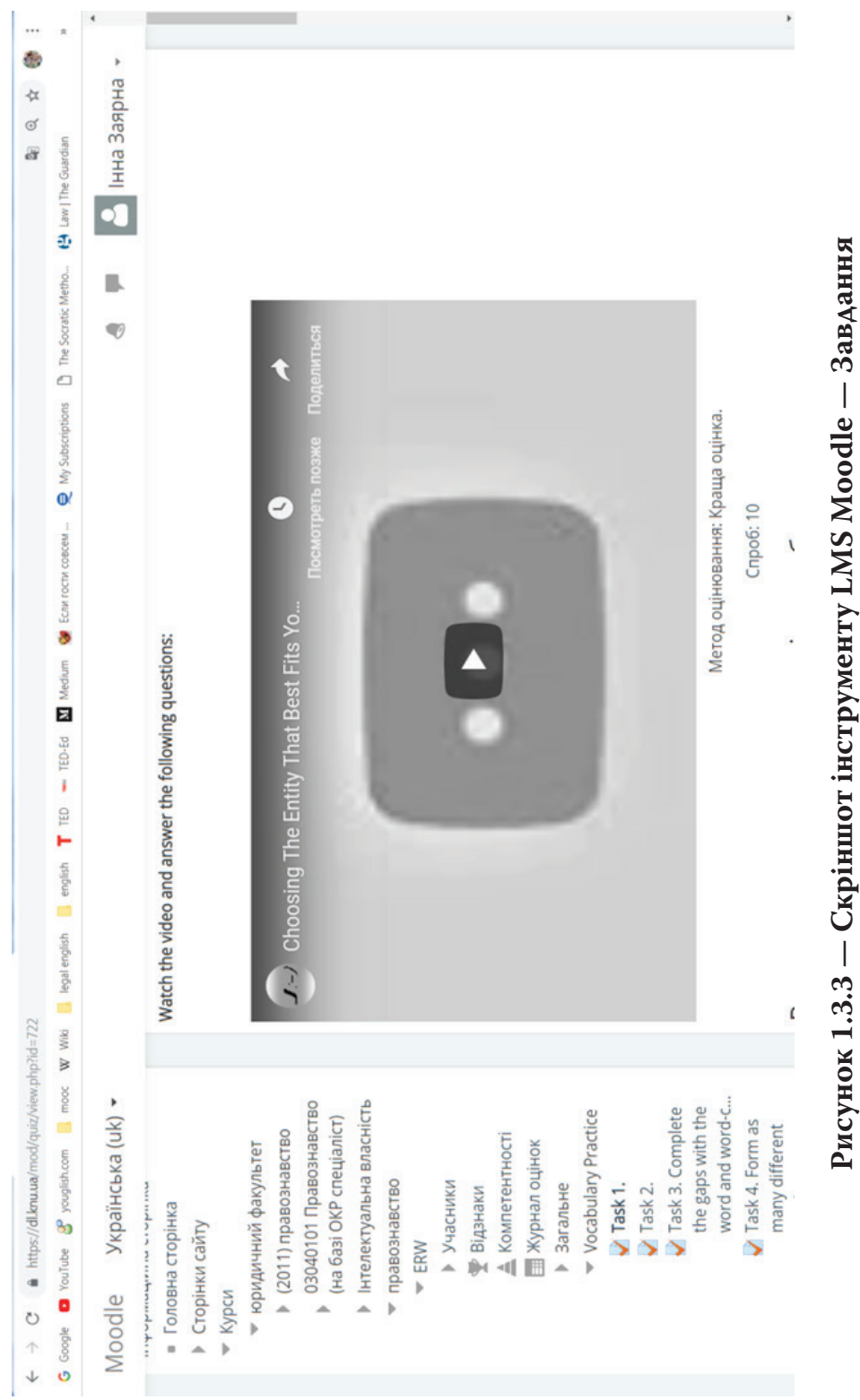


Розділ 1. Теоретичні засади дистанційного навчання англійського аргументативного письма майбутніх правознавців

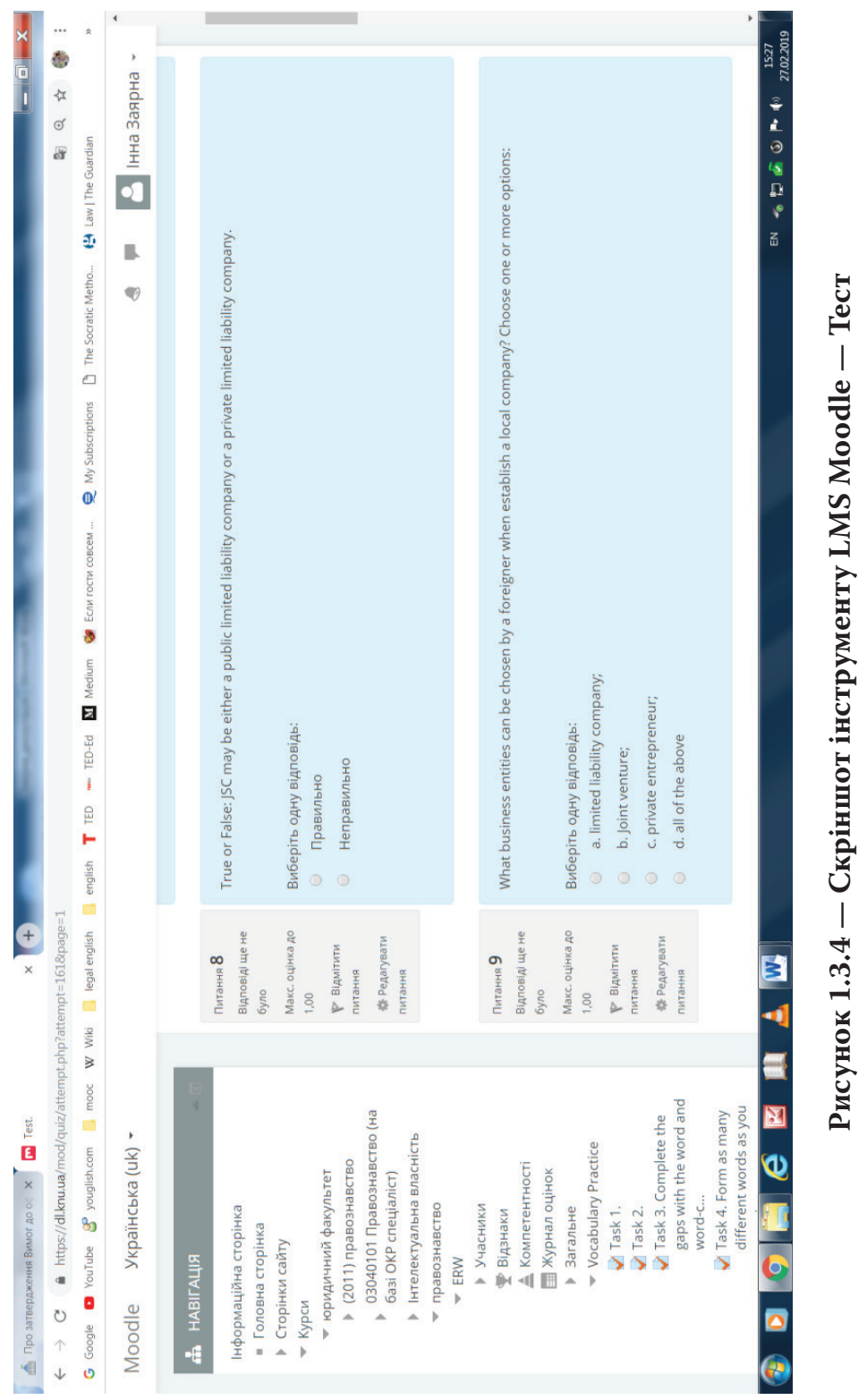

79 
Заярна І.С. Методика дистанційного навчання

англійського аргументативного письма майбутніх правознавців

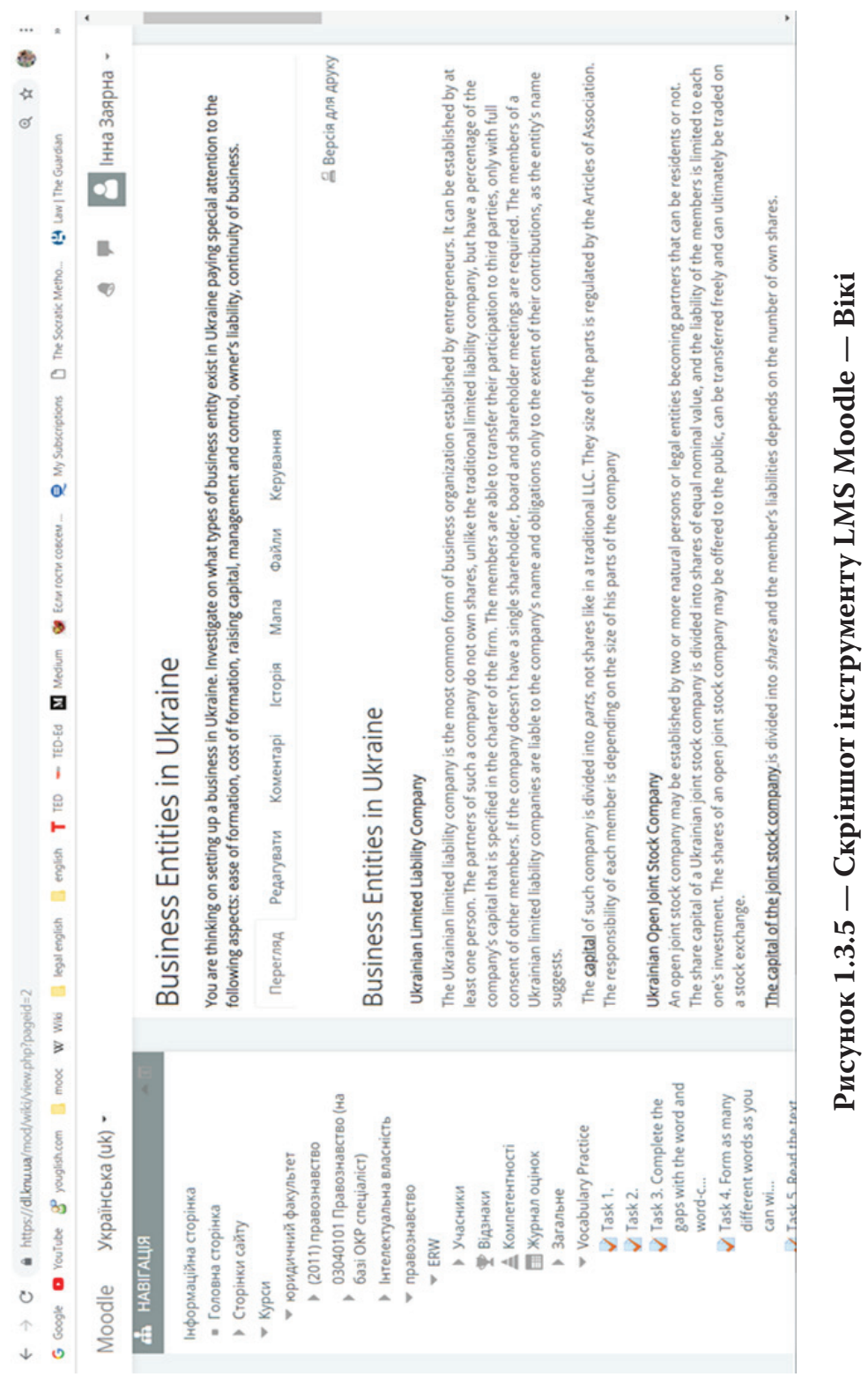


Розділ 1. Теоретичні засади дистанційного навчання англійського аргументативного письма майбутніх правознавців

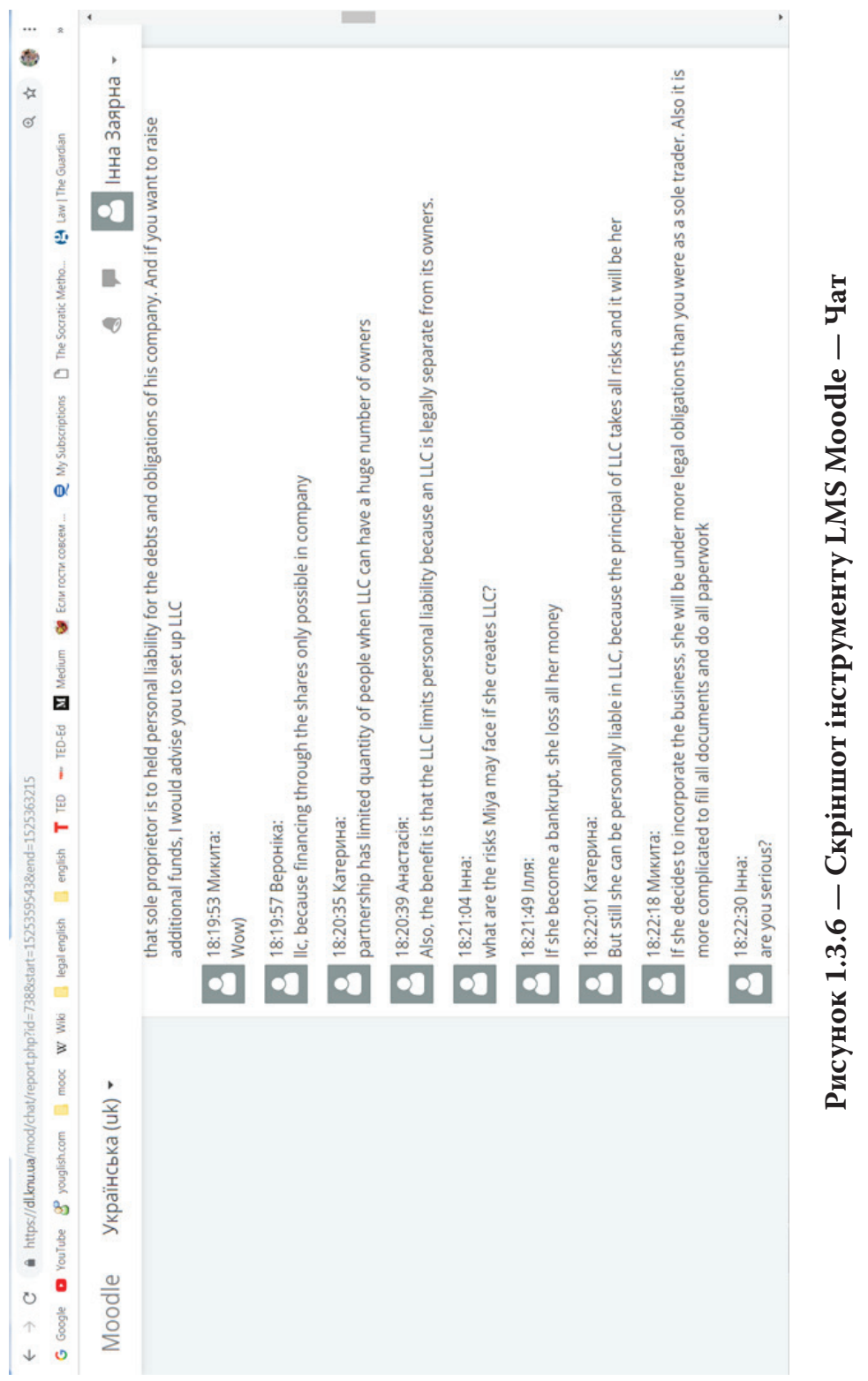


Анаціз наукової мітератури ${ }^{186},{ }^{187},{ }^{188},{ }^{189},{ }^{190},{ }^{191}$ Аав можмивість встановити, що Аистанційне навчання англійського аргументативного письма студентів-юристів має здійснюватися з позицій конструктивістського, компетентнісного та жанрового піАхоАів. Конструктивістський підхід розглядається провіАними вченими як кмючовий у процесі Аистанційного навчання ${ }^{192}$. IАeї конструктивізму також покмадені в основу систем керованого навчання, зокрема платформи Moodle ${ }^{193}$, на базі якої віАбувається навчання англійського аргументативного письма студентів-юристів.

Головна іАея, покцадена в основу конструктивістського піАходу, полягає у створенні можливостей Аля студентів самостійно «конструювати» власні знання, вміння та навички в процесі навчальної Аіяльності, а не отримувати їх

${ }^{186}$ Бігич О. Б. Різновиди професійно орієнтованого підходу до навчання іноземної мови як непрофільної Аисципиіни. II Міжнародна науково-практична конференція «Комунікація у сучасному соціумі». 8 червня 2018. URL: https://conferences.lnu.edu.ua/ index.php/communicatios/communication-2018/paper/view/24

${ }^{187}$ Биков В. Ю., Кухаренко В. М., Сиротенко Н. Г., Рибалко О. В., Богачков Ю. М. Технологія створення Аистанційного курсу: навчальний посібник / за реА. В. Ю. Бикова, В. М. Кухаренка. Київ: Мікеніум, 2008. 324 с.

${ }^{188}$ Малкова Н. В. ВАияние конструктивистских идей на содержание подготовки учитемя в США // ПеАагогика. 2008. № 2. С. 75-80.

${ }^{189}$ Рудніцька К. В. Сутність понять «компетентнісний піАхіА», «компетентність», «компетенція», «професійна компетентність» у світлі сучасної освітньої парадигми. Науковий вісник Ужгородського університету. 2016. Серія: «ПеАагогіка. Соціальна робота». Випуск 1 (38). С. 241-244.

${ }^{190}$ Шевніна $\Lambda$. Є. Формування жанрової компетенції в англійському Аіловому писемному мовменні майбутніх менеАжерів туризму: автореф. Аис. канА. пеА. наук: 13.00.02; ПНПУ ім. К. А. Ушинського. ОАеса, 2012. 23 с.

${ }^{191}$ Auerbach E. R. Competency-based ESL: One step forward or two steps back. TESOL Quarterly. 1986. Vol. 20 (3).

${ }^{192}$ Bykov V. Yu., Kuharenko V. M., Molodyh A. S. Influence of Learning Process Organization on Students' achievments in Distance Education. Інтернет-Освіта-Наука-2004: матеріали 4-і Міжнародної конф., м. Вінниця, Універсум. Вінниця, 2004. Р. 87.

${ }^{193}$ Moodle. Pedagogy Electronic resource: URL: https://docs.moodle.org/21/en/Pedagogy. 
У готовому вигАяАі, при цьому сам навчаАьний процес віАтворює або моделює екстралінгвістичну Аійсність і Аіяльність, зараАи яких вивчається мова ${ }^{194}$. 3 позицій конструктивістського піАходу, знання не передаються віА викмаАача Ао студента, але $\epsilon$ індивіАуамьною інтерпретацією отриманої інформації. Студенти розглядаються як активні учасники контекстного навчамьного процесу, при цьому ромь викмаАача змінюється віА транслятора професійних знань Ао консультанта, який скеровує, стимулює та піАтримує студентів у процесі вирішення навчальних задач на шияху формулювання самостійних Аумок та в асних висновків ${ }^{195}$.

Аналіз концептуальних іАей теорії конструктивізму Аає змогу сформулювати його основні положення в контексті Аистанційного навчання ангмійського аргументативного письма студентів-юристів.

- Аистанційне навчання ангхійського аргументативного письма $\epsilon$ ефективне, коми всі учасники навчального процесу $\epsilon$ одночасно і викладачами, $і$ студентами. Це передбачає зміну ролі викладача віА «носія знань» до «провіАника», який скеровує роботу студентів, завАанням яких $є$ навчитися, а не бути навченими. Бажаний результат в умовах $А \mathrm{H}$ Аосягається завАяки тому, що стуАенти отримують інформацію 3 першоджерел та явищ реацьної Аійсності.

- Аистанційне навчання ангхійського аргументативного письма є більш ефективним, якщо відбувається в діï: створюючи і Аемонструючи матеріал іншим зростає власна персональна віАповідальність студента, більше часу приділяється самоперевірці та роздумам, що безперечно покращує резуль-

194 Заболотська О. О. Актуацьні проблеми методики викцадання англійської мови. URL: http://ekhsuir.kspu.edu/bitstream/123456789/1195/1/_1_doc\%20\%282\%29.pdf.

${ }^{195}$ Малкова Н. В. ВАияние конструктивистских идей на содержание подготовки учителя в США // ПеАагогика. 2008. № 2. С. 76. 
тати навчання. Інструменти віртуа^ьних навча^ьних середовищ такі як Wiki, Форум, Чат створюють платформу Аля обміну іАеями та сприяють спільній роботі студентів та викмадача.

- Ефективність Аистанційного навчання англійського аргументативного письма зростає, якщо існує можливість спостерігати за навчанням інших, аналізувати ї роботу $i$ працювати в одному спільному ритмі. В умовах Аистанційного навчання це Аосягається завАяки чітко встановленим АеАлайнів, що Аозволяє синхронний перехіА віА оАного етапу навчання на інший.

- Ефективність Аистанційного навчання англійського аргументативного письма залежить віА вміння усвідомлювати та враховувати індивідуальні особливості учасників навчального процесу шияхом створення сприятливих умов Аля самореалізації та самопрезентації студентів. Особливу цінність становцять індивідуацьність мислення, розсуАливість, вміння виправАяти власні помилки.

- Аистанційне навчання англійського аргументативного письма $\epsilon$ ефективним, якщо навчальний процес $\epsilon$ гнучким, тобто надає учасникам різноманітні способи, засоби та інструмент Аля реалізації своїх навчальних потреб.

- Аистанційне навчання англійського аргументативного письма $є$ більш ефективним за умови залучення студентів до розв'язання складних задач, без їх цілеспрямованого спрощення. Це спонукає Ао пошуків нових аргументів чи/та трансформації існуючих.

Таким чином, конструктивістський піАхіА забезпечує ефективну організацію навчального процесу, спрямованого на формування умінь та навичок англійського аргументативного письма в умовах Аистанційної освіти. Завдання викмадача сприяти самостійному отриманню нових знань студентами, організовуючи їх спільну роботу Аля обміну Аумками та іАеями. 
Розвиток аргументаційних умінь, зокрема, досягається шияхом розв’язання завдань, які передбачають пошук додаткових аргументів та способів їх формулювання. 3 позицій конструктивістського підходу до Аистанційного навчання англійського аргументативного письма важливим $є$ вміння мислити критично, уникати шаблонів, вміти виправляти власні помилки.

Компетентнісний niдxiд Ао навчання англійського аргументативного письма передбачає спрямованість освітнього процесу на формування та розвиток загальних і професійних компетентностей майбутнього юриста. Погоджуємося 3 К.В. РуАніцькою, що застосування компетентнісного піАходу Ао навчання англійського аргументативного письма вимагає зміни акценту «з процесу накопичення нормативно визначених знань, умінь і навичок майбутніх фахівців у площину формування і розвитку зАатності практично Аіяти і творчо застосовувати набуті знання і досвіА у різних ситуаціях» ${ }^{196}$. Таким чином, навчання англійського аргументативного письма 3 позицій компетентнісного піАходу має спиратися на соціальний контекст, а не викцаАатися ізольовано, та будуватися не навколо поняття «знання», а навколо поняття «компетенція».

Практична реалізація компетентнісного піАходуАо навчання англійського аргументативного письма засобами дистанційних технологій передбачає врахування його наступних основних положень (за E.P. Ауербах (E.R. Auerbach) ${ }^{197}$ :

- Націленість на здатність кожного студента-юриста автономно впоратися із завданням. Аистанційне навчання повною мірою реалізує дане завдання, завдяки гнучкості та

${ }^{196}$ Рудніцька К. В. Сутність понять «компетентнісний піАхіА», «компетентність», «компетенція», «професійна компетентність» у світлі сучасної освітньої парадигми / Науковий вісник Ужгородського університету. 2016. Серія: «ПеАагогіка. Соціальна робота». Випуск 1 (38). С. 241.

${ }^{197}$ Auerbach E. R. Competency-based ESL: One step forward or two steps back. TESOL Quarterly. 1986. Vol. 20 (3). P. 414-415. 
індивідуалізації навчального процесу, коли студенти мають можливість навчатися у власному темпі, приАіляючи кожній вправі і завданню необхіАну кількість часу, що в результаті Аозволяє виконати завАання автономно.

- Націленість на пробесійні знання, навички та уміння юриста. Студенти вивчають мише ті мовні форми, набувають умінь та навичок, що характерні ситуаціям, в яких вони функціонуватимуть. Це вимагає ретельного Аобору мовного та мовценнєвого матеріалів, розробки системи вправ Аця вправАяння в англійському аргументативному письмі та способів ïх Аоставки до студентів в умовах віртуацьного навчацьного середовища.

- Націленість на результат. ПіА результатом навчання англійського аргументативного письма ми будемо розуміти зАатність студента скмасти юриАичний текст віАповіАного жанру (Аист-пораАа, позовна заява, меморандум та ін.). Аистанційне навчання англійського аргументативного письма переАбачає схему 40/60, де 40 балів студент може заробити виконавши успішно формуючі вправи, а в 60 балів оцінюється підсумкове (контрольне) завдання. Крім того, студент зможе почати виконання контрольного завАання $и$ за за умови успішного виконання формуючих вправ і завдань.

- Спрямованість на модульні інструкції. Задачі подікяються на підзадачі заради чіткого бачення прогресу як викмаАачем, так і студентами. У віртуальному навчальному середовищі підзадачі реалізуються окремими інструментами системи Аистанційного навчання.

- Спрямованість на особистісно-орієнтовані інструкції. За своїм змістом, рівнем і темпом, завдання визначаються в умовах професійних потреб студента, а попередні знання та Аосягнення студента обов'язково беруться Ао уваги Аця розробки Аистанційного курсу. 
- Націленість на чіткість завдань та їх відповідність очікуваному результату. Це правило $\epsilon$ справедиивим на кожному етапі навчання. Якщо кінцевим результатом навчання англійського аргументативного письма $\epsilon$ зАатність скиасти юриАичний текст віАповіАного жанру, то на проміжних етапах студента мають усвідомлювати, що формуючі вправи і завдання націлені на Аосягнення проміжних результатів (вивчення мовного матеріалу, характерного Ааному жанру, його структури, аргументативного компоненту).

- Націленість на постійне оцінювання. ПіА час навчання англійського аргументативного письма кожний виА Аіяльності оцінюється, а подальше навчання можливе кише за умови Аолання попереднього етапу. Технології дистанційного навчання наАають аАміністративні можливості викцадачу встановлювати кількість спроб та час на виконання завдання. Крім того, Аистанційне навчання переАбачає миттєвий зворотній зв'язок, коли студенти можуть бачити свої результати безпосереАньо після їх виконання. Кожне завдання в умовах Аистанційного навчання оцінюється або системою, або виклаАачем. ПереАбачаємо як формуюче оцінювання піА час усього навчання, так і піАсумкову оцінку.

- Спрямованість на демонстровану майстерність виконання завдань. На відміну віА традиційних тестів, оцінювання навчальних Аосягнень студентів-юристів базується на зАатності Аемонструвати моделі поведінки, що обумовлені ситуацією. Використовуючи комепетнтнісного піАходу Ао навчання англійського аргументативного письма, майбутні юристи вчаться вживати мову в автентичних ситуаціях, в яких вони вірогіАно опиняться поза навчальним процесом.

Отже, в аспекті компетентнісного підходу Аистанційне навчання англійського аргументативного письма передбачає успішне виконання піАсумкового автентичного завАання - 
написання юридичного тексту віАповіАного жанру. Навчання студентів відбувається автономно з урахуванням їх індивідуальних особливостей та навчальних досягнень. На кожному етапі навчання студенти отримують зворотній зв'язок віА викцаАача та/або системи Аистанційного навчання з метою іАентифікації своїх слабких сторін та їх вчасного подолання заАля успішного виконання піАсумкового завдання. Навчацьні матеріали та завАання мають бути автентичними, тобто віАповіАати існуючій юриАичній практиці ${ }^{198}, 199$.

Аналіз існуючих піАходів Ао навчання іншомовного писемного мовлення Аозволив нам виокремити жанровий підхід як найбільш ефективний з точки зору функціональності та прагматичності піА час навчання англійського аргументативного письма студентів-юристів. ЗгіАно цього піАхоАу ми розгАяАаємо навчання ангмійського аргументативного письма в соціальному контексті, коли письмовий текст створюється Аһя вирішення позамовної задачі. Спираючись на Аослідження $\Lambda . €$. Шевніної 200, припускаємо, що жанровий піАхіА Ао навчання англійського аргументативного письма зАатний забезпечити зАатність студентів-юристів створювати власні тексти віАпо-

198 Заярна І.С. Особливості застосування компетентнісного підходу Ао навчання ангАійського аргументованого писемного мовцення студентів юридичного профілю. Вісник Запорізького націонацьного університету: збірник наукових праць. Педагогічні науки. Запоріжжя: Запорізький національний університет, 2016. № 1. C. 163-164.

${ }^{199}$ Zaiarna I.S. Competency-based Approach to Teaching English Reasoning Writing to Law Students: General Characteristics. КАасичний університет у контексті викциків епохи (Classic University in the context of Challenges of the Epoch) : матеріали українсько-польської міжнародної наукової конференції (м. Київ, 22-23 вересня 2016 року). УкмаА.: А. С. Філіпенко та ін. К. : Київський національний університет імені Тараса Шевченка, 2016. С. 150.

${ }^{200}$ Шевніна $\Lambda$. Є. Формування жанрової компетенції в англійському Аіловому писемному мовценні майбутніх менеАжерів туризму: автореф. Аис. ... канА. пеА. наук: 13.00.02; ПНПУ ім. К. А. Ушинського. ОАеса, 2012. С. 6. 
відних жанрів шияхом усвідомиення мотивів, через які створюються ці тексти, способів їх інтерпретації та використання в професійних ситуаціях спілкування ${ }^{201}$.

УсліА за О.О. Москалець, вважаємо, що методична робота наА текстом віАповіАного жанру повинна вкцючати наступні етапи: загальний аналіз професійної ситуації спілкування юриста, у якій створюється текст обраного жанру; опрацювання тексту-зразка обраного жанру та анаціз його змісту; аналіз мовних і позамовних особливостей тексту; опрацювання аргументативних тактик; написання першого варіанта тексту (індивідуальне або групове); самоаналіз або взаємоаналіз написаного із залученням пам'яток Аля самоконтролю та Аопомоги викмадача; індивіАуальна робота наА мексичними, граматичними та орфографічними помилками на рівні окремих речень; індивідуальна робота наА аргументативними тактиками; індивідуальне або групове вдосконалення написаного тексту; презентація створеного тексту, кількісна і якісна оцінка викмадачем ${ }^{202}$.

Розглянута вище типова процеАура навчання англійського аргументативного письма Аозволяє навчити писати тексти різноманітних жанрів юриАичного аргументативного мовлення та різного рівня їх складності. В свою чергу середовище Аистанційного навчання створює технічні можиивості ААя ефективної реалізації кожного етапу навчання як піА час індивідуальної роботи студента, так і їх спільної роботи в онлайн-

201 Заярна I. С. Застосування жанрового підходу до навчання англійського аргументованого писемного мовиення студентів юридичного профілю. Іншомовна піАготовка працівників правоохоронних органів і сектору безпеки: матеріали III Міжнародної науково-практичної конференції (27 березня 2019 року). Київ: Націонацьна академія прокуратури України, 2019. С. 61.

${ }^{202}$ Москалець О. О. Етапи навчання іншомовного писемного мовлення як засобу спілкування. URL: file://C:/Users/\%D0\%9E\%D0\%BB\%D0\%B5\%D0\%B3/Downloads/Nzspp_2012_6_20.pdf. 
групах. Таким чином, жанровий підхід до навчання англійського аргументативного письма успішно реалізується в умовах Аистанційного навчання та віАповідає цікям i завданням англійського аргументативного письма, аАже акцентує увагу на ті жанри, які $\epsilon$ характерними Аһя іншомовного писемного мовцення сучасного юриста.

Проаналізовані піАходи визначають загальну стратегію Аистанційного навчання англійського аргументативного письма, реалізація якої вимагає вивчення інших піАпорядкованих концептуацьних положень, таких як принципи та методи Аистанційного навчання англійського аргументативного письма. Розглянемо їх детально.

Аистанційне навчання англійського аргументативного письма грунтується на низці принципів. Спираючись на результати АосліАжень вчених-методистів ${ }^{203},{ }^{204},{ }^{205},{ }^{206},{ }^{207},{ }^{208}$, кАючовими у процесі Аистанційного навчання англійського аргументативного письма нами буки визначені такі дидактичні (посильності, свідомості, активності, наочності), психологічні

203 Заярна I. С. Принципи е-навчання англійського аргументативного письма майбутніх правознавців. Подолання мовних та комунікативних бар'єрів: освіта, наука, культура : збірник наукових праць. За реА. О. В. Ковтун, С. М. Ягодзінського. К. : НАУ, 2019. С. 231-235.

${ }^{204}$ Аяховицкий М. В. Методика преподавания иностранных языков: учеб. пособ. Аля филол. спец. вузов. Москва: Высшая школа, 1981. 159 с.

${ }^{205}$ Методика навчання іноземних мов у загальноосвітніх навчальних закладах: піАручник. А. С. Панова, І. Ф. Андрійко, С. В. Тезікова та ін. Київ: ВЦ «Академія», 2010. Серія «Амьма-матер». 328 с.

${ }^{206}$ Методика викмадання іноземних мов у середніх навчальних закладах: підручник. ВиА. 2-е, випр. і перероб. Кол. авторів піА керівн. С. Ю. Ніколаєвої. Київ: Аенвіт, 2002. 328 с.

${ }^{207}$ Щукин А. Н. Обучение иностранным языкам: теория и практика: учеб. пособ. Аля преподавателей и студентов. Москва: Фимоматис, 2006. 480 с.

${ }^{208}$ Юнчик В. $\Lambda$. Методичні особливості Аистанційного навчання. Збірник наукових праць. Наукові записки Рівненського державного гуманітарного університету. Випуск 7 (50), 2013. URL: file://C:/Users/\%D0\%9E\%D0\%BB\%D0\%B5\%D0\%B3/Downloads/ Ozfm_2013_7_67.pdf. 
(принципи мотивації, поетапності формування мовменнєвих умінь та навичок, врахування індивідуально-психологічних особливостей особистості студента, врахування аАаптаційних процесів) та методичні (комунікативності, автентичності, професійної спрямованості навчання, ситуативно-тематичної організації навчання) принципи. Варто зауважити, що Аидактичні та психологічні принципи навчання спрямовані в першу чергу на врахування умов нового Аля студентів середовища навчання, яке реалізується через інтерфейс цифрових засобів

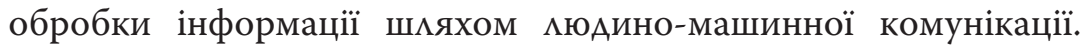
Методичні ж принципи відображають особливості викладання англійського аргументативного письма студентам-юристам, не залежать віА середовища їх застосування і повинні в рівній мірі використовуватися як піА час традиційної, так і Аистанційної форми навчання.

ВіАповіАно до принцииу свідомості, процес навчання англійського аргументативного письма засобами віртуальної системи Moodle розгляааємо як цілеспрямоване самонавчання студентів-юристів, які усвіАомлюють архітектуру Аистанційного курсу, принцип роботи інструментів (сервісів) платформи, проміжні та остаточні результати навчання, особАивості оцінювання та контролю у технічно опосереАкованому середовищі.

Принцип активності передбачає активну участь студентівюристів у процесі навчання англійського аргументативного письма на різних рівнях (інтелектуальному, емоційному та мовленнєвому). ЗаАля успішного проходження Аистанційного курсу студенти повинні самостійно виконати всі як індивідуальні, так і групові завдання, не пропустивши термінів їх зАачі. Ми розглядаємо принцип активності як оАин з кАючових в метоАиці Аистанційного навчання англійського аргументативного письма, аАже запорукою Аосягнення резуцьтатів $€$ індивідуацьна 
активність кожного студента. ПіА час Аистанційного навчання англійського аргументативного письма ми використовуємо аАміністративні сервіси (Звіти, Журнац оцінок), щоб спостерігати за рівнем активності кожного окремого студента (скільки часу було витрачено на виконання завдання, коли в останнє студент був активним в системі, активність кожного окремого студента по віАношенню Ао групи та ін.), а за Аопомогою інструменту Анкета визначаємо рівень зацікавленості студента Ао виконання кожного окремого завдання та курсу загалом.

ЗгіАно з приниипом посильності, навчання англійського аргументативного письма має віАбуватися із урахуванням рівня технічної підготовки студентів. ПереА початком дистанційного курсу за Аопомогою спеціальних тестів важливо визначити та в подальшому враховувати рівень психологічної готовності студентів до роботи у віртуацьному середовищі, їх технічні уміння та навички роботи з сервісами платформи Moodle. ПіА час розробки дистанційного курсу, спрямованого на оволоАіння уміннями в англійському аргументативному письмі с $\Lambda$ іА також розраховувати час, необхіАний студентам Аля виконання завдання та його обсяг.

Мінімізувати зусиция, яких Аокмадає студент Аля сприйняття змісту навчального матеріалу, можна шияхом застосування принципу наочності, який забезпечується простотою і зрозумілістю мюдино-машинного інтерфейсу, через який відбувається взаємодія студента 3 комп'ютером. Віртуальне середовище Аля навчання англійського аргументативного письма має містити зону входу, Ае розміщуються організаційні блоки, через які зАійснюється навігація по сайту. При поданні вербальної інформації сліА паралельно преА'явмяти всю потрібну Аопоміжну інформацію, використовуючи кілька різних комунікаційних каналів (слуховий, зоровий та ін.). Окрім Аобре організованого змісту навчального мате- 
ріалу, варто приділити увагу і формі його презентації на сайті. Розташування, колір, форма об'єктів мають максимацьно полегшувати сприйняття нової інформації, не обтяжуючи мозок студента Аодатковою інформацією, але водночас мають привертати і утримувати його увагу до основної мети і завАань навчамьної Аіяльності. Так, фахівці з веб-дизайну звертають особливу увагу на розташування об'єктів, а саме на використання «білого простору» або, як його ще називають, «зони віАпочинку» ${ }^{209}$. Простір, вільний віА будь-яких об’єктів, Аає можмивість не кише «віАпочинку» віА інформації, але й тим самим змінює фокус на значущий Аля навчальної Аіяльності матеріал. Важмиве значення Аля ефективного сприймання інформації мають кольори, їх тон, віАтінок та інтенсивність. Встановлено, що урівноважене в колірному відношенні сереАовище привертає і надихає, створює творчу атмосферу, заспокоює і сприяє спілкуванню ${ }^{210}$. Близько $66 \%$ уваги приділяють саме кольору. Так, з точки зору психологічної ефективності найбільш вАалими $є$ жовтий, бірюзовий, синьо-фіометовий і рубіновий ${ }^{211}$. Типи шрифту, висота строки, віАстань між знаками та абзацами також віАіграють психологічну роль в процесі сприймання інформації, а тому мають бути враховані в процесі реалізації принципу наочності піА час створення Аистанційного курсу, спрямованого на оволоАіння уміннями в англійському аргументативному письмі.

Приниип мотивації реалізується за рахунок врахування інтересів студентів, їх вікових особливостей та мотивів

${ }^{209}$ Психология веб-дизайна. Как цвета, шрифты и разметка вмияют на ваше настроение. URL: http://lpgenerator.ru/blog/2016/03/14/psihologiya-veb-dizajna-kak-cveta-shrifty-i-razmetka-vliyayut-na-vashe-nastroenie/.

${ }^{210}$ Бучинська О. В. Психологія кольору як метод якісного маркетинг. Вісник ОНУ імені І. І. Мечникова. 2015. Т. 20. Вип. 1/1. С. 76.

211 Так само, С. 78. 
навчання. Мотивація студентів до зАійснення навчальної Аіяльності, опосередкованої компютером, може бути різноманітною. А.В. Васицьченко виАіляє такі види мотивації, притаманні Аистанційній формі навчання: Аілова, пізнавацьна, мотивація співробітництва, самореалізації і розвитку рекреційності, афікяції ${ }^{212}$. Основним мотивом, характерним Аля Аистанційного навчання ангАійського аргументативного письма як навчальної Аіяльності, вважаємо пізнавацьний інтерес, «який активно взаємодіє із системою ціннісних орієнтацій, метою, результатами Аіяльності, відображає всі скмаАові особистості: інтелект, волю, почуття» ${ }^{213}$.

Аля підтримки мотивації студентів на високому рівні піА час Аистанційного навчання важливо піАтримувати психологічну комфортність, піА якою сліА розуміти не мише фізичну зручність процесу навчання, але й задоволення базових психомогічних потреб студента. Важливо уникати оцінних суАжень в Аіалозі студент-комп'ютер, не Аопускати висловів, які можуть бути сприйняті як образмиві, обережно використовувати жарти, а зауваження робити у формі пораАи, а не жорсткої критики.

Принцип поетапності формування мовленнєвих умінь та навичок піА час Аистанційного навчання переАбачає чотири етапи формування аргументаційно-писемно-мовленнєвої Аіяльності (за А.М. Щукіним): ознайомчий, піА час якого віАбувається ввеАення нових мексичних одиниць, граматичних структур, правим аргументації, характерних окремому жанру аргументативного писемного мовлення; стандартизуючий,

${ }^{212}$ Васицьченко А. В., Шевченко В. $\Lambda$. Аистанційне навчання: науково-метоАичне забезпечення; інформаційний простір навчального закцаАу. Харків: Основа, 2009. C. 64.

${ }^{213}$ Боднар А. Я., Макаренко Н. Г. Шияхи формування пізнавального інтересу особистості в процесі професійного самовизначення. Наукові записки. Педагогічні, психологічні науки та соціальна робота. Том 162. С. 33. 
спрямований на формування мовленнєвої навички шияхом виконання мовних справ; вар'юючий, піА час якого віАбувається удосконалення мовленнєвих та аргументаційних навичок в ситуаціях навчацьного спілкування; та творчий, націлений на розвиток мовленнєвих та аргументаційних умінь та навичок в різноманітних ситуаціях як навчахьного, так і професійного характеру ${ }^{214}$.

Приниип врахування індивідуально-исихологічних особливостей особистості студента передбачає обізнаність викладача про особисті якості студентів, їх світогляА, сферу бажань та інтересів, статус в групі та максимацьне врахування Ааних характеристик в навчацьному процесі. ПіА час Аистанційного навчання ангмійського аргументативного письма с $\Lambda$ iА враховувати наступні групи індивіАуально-психологічних чинників, які впливають на результативність навчання (усліА за О.М. Харою): гендер, типи темпераменту, Аомінування півкуль, реакції на виконання завдання, типи сприймання інформації, типи сприйняття та узагальнення інформації, типи визначення цілей, ставлення Ао вибору, типи скухачів згіАно стратегії управ $і н$ я $^{215}$.

Принцип врахування адаптаційних процесів застосовується у зв'язку 3 необхіАністю пристосування студентів Ао нових умов технічно опосереАкованого навчання та швиАкому подоланню пов'язаних 3 цим труАнощів. ПіА час Аистанційного навчання англійського аргументативного письма подомати психологічний Аискомфорт, пов'язаний з безособистісним характером технічних засобів, будемо шляхом свіАомого створення Аружньої навчальної онцайн спільноти, націленої на

${ }^{214}$ Щукин А. Н. Обучение иностранным языкам: теория и практика: учеб. пособ. Аця преподавателей и студентов. Москва: Фимоматис, 2006. С. 162-163.

${ }^{215}$ Хара О. М. Психологічні особливості дистанційного навчання математики // Математика в школі. 2008. № 7/8. С. 32-35. 
формування якісних і глибоких взаємин між студентами. Реалізація віртуального спілкування в межах системи управління навчанням Moodle відбувається за допомогою таких інструментів як Чат, Форум та Обмін повідомленнями.

ВіАповідно Ао методичного приниип комунікативності, процес навчання англійського аргументативного письма реалізується шияхом моделювання типових професійних ситуацій, характерних Аля правової сфери. Результатом навчання англійського аргументативного письма $\epsilon$ скмаАання типових юридичних Аокументів (Аист-порада, позовна заява, меморандум та ін.), які націлені на вирішення конкретних правових спорів в різних галузях права (Аоговірне право, господарське право, цивільне право, право інтелектуальної власності тощо). Реалізація принципу комунікативності піА час навчання англійського аргументативного письма відбувається шляхом Аобору типового Ао ситуацій спілкування мовного та мовленнєвого матеріацу, віАповіАних схем аргументації (текст-повного спростування тези, текст-часткового спростування тези, текст-обгрунтування, полемічний текст) та характерних вправ, метоАів та прийомів навчання.

Приниип автентичності передбачає використання автентичних юридичних текстів визначених жанрів англійського аргументативного письма 3 метою їх аналізу та наслідування. Автентичні юридичні тексти відображають реальне писемне мовлення носії англійської мови та слугують Ажерелом мовного і мовценнєвого матеріалу Аля навчання англійського аргументативного письма.

ЗгіАно з приниипом професійної спрямованості навчання, навчання ангАійського аргументативного письма відбувається в межах юридичної сфери та у віАповіАності Ао вітчизняної юриАичної практики, Аіючого законодавства та норм міжнародного права. За результатами навчання студенти мають 
оволодіти жанрами юриАичних текстів, 3 якими безпосереАньо працюють юристи піА час виконання своїх професійних обов'язків. Аексичні одиниці, граматичні структури, аргументаційні схеми мають відповідати кращим зразкам існуючої юриАичної практики.

Принцип ситуативно-тематичної організації навчання реалізується шияхом Аобору типових Аля юридичного аргументативного писемного мовцення ситуацій, які моделюють реальне спілкування. Кожна тема представ яє собою завершений модуль, спрямований на вивчення конкретного жанру ангмійського аргументативного письма, який містить змістовий блок, мексико-граматичний блок, аргументаційний блок та власне творчий блок, націкений на створення власного письмового тексту.

Важливим аспектом реалізації перелічених вище принципів навчання англійського аргументативного письма майбутніх юристів $є$ технологї навчання. Аналіз науково-методичної

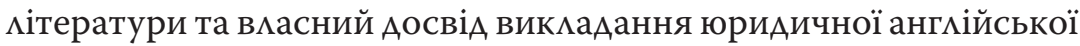
мови Аозволив нам визначити як основні у процесі навчання англійського аргументативного письма такі технології як метод кейсів та метод Сократа. Ці технології спрямовані на оволоАіння необхіАними аргументативними уміннями та навичками, віАповіАають вищезазначеним піАходам і принципам та ефективно реалізуються в умовах Аистанційного навчання.

Meтод кейсів (англ. case method, кейсметод, кейс-стаді, casestudy, метод конкретних ситуацій) будемо визначати як метоА навчання, заснований на вирішенні конкретних проблемних ситуацій, які «потребують певного неоднозначного і, зазвичай, креативного рішення» ${ }^{216}$. Кейс-метоА широко застосовується вітчизняними і зарубіжними практиками у навчальному процесі

216 Чорна І.Ю. Формування у майбутніх маркетологів англомовної мексичної компетентності в письмі засобами кейс-технології : Аис. ... канА. пеА. наук: 13.00.02. Тернопімь, 2017. С. 74-75. 
вищої школи як засіб моделювання професійної Аіяльності зі спеціальних Аисциплін, зокрема, юридичних ${ }^{217}$.

Аля викмадання англійської мови за професійним спрямуванням метоА кейсів використовується методистами з 1967 року $^{218}$. КАючова ідея, покладена в його основу, полягає в «самостійній пізнавацьній Аіяльності студентів у штучно створеному професійному середовищі, яке Аає можливість поєАнати теоретичну піАготовку і практичні вміння, необхіАні Аля творчої Аіяльності у професійній сфері» ${ }^{219}$. Як влучно зазначає О.В. Аюбашенко, кейс-метод пов'язаний із моделюванням реальної комунікативної ситуації, спрямованої на аналіз

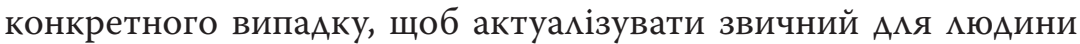
спосіб мислення, поведінки, мовлення ${ }^{220}$.

Передбачаємо, що реалізація методу кейсів піА час Аистанційного навчання англійського аргументативного письма сприятиме формуванню та розвитку таких необхіАних Аля англійського аргументативного письма професійних умінь як вміння виробляти та приймати рішення; системне мислення; самостійність та ініціативність; готовність до змін та гнучкість; комерційна та Аілова орієнтація; вміння працювати 3 інформацією; завзятість і цілеспрямованість; проблемність мислення; конструктивність; зАатність до аналізу і Аіагностики проблем,

217 Ярошенко О.В. Кейс-метоА як сучасна технологія формування професійно орієнтованої компетентності в Аіалогічному мовленні майбутніх викцадачів англійської мови. Іноземні мови. №2 (78). 2014. C. 39. URL: file://C:/Users/\%D0\%9E\%D0\%BB\%D0\% B5\%D0\%B3/Downloads/122479-260958-1-SM\%20(1).pdf

${ }^{218}$ Brattseva E. F., Kovalev P. The power of case study method in developing academic skills in teaching Business English (time to play) // Liberal Arts in Russia. 2015. Vol. 4. No. 3. P. 234.

${ }^{219}$ Козак $\Lambda$. В. Кейс-метод у підготовці майбутніх викмадачів до інноваційної професійної Аіяльності // Освітологічний Аискурс. 2015. № 3 (11). С. 154.

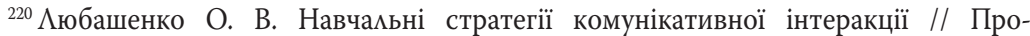
блеми теорії і методики навчання іноземних мов. 2016. C. 294. URL: file://C:/Users/ \%D0\%9E\%D0\%BB\%D0\%B5\%D0\%B3/Downloads/nvnau_fil.n_2016_245_42.pdf. 
вміння чітко формулювати і висловлювати свою позицію, сприймати й оцінювати інформацію, яка надходить у вербальній і невербальній формах $221,222,223,224$.

Важливим аспектом залишається також добір навчального матеріалу, який варто зАійснювати у віАповіАності Ао низки критеріїв: 1) професійної спрямованості; 2) автентичності; 3) проблемності; 4) ситуативності; 5) Аоступності; 6) міжпреАметності ${ }^{225}$.

ПіА час Аистанційного навчання англійського аргументативного письма студентам-юристам пропонується вирішити реальну юридичну проблему, характерну професійній Аіяльності правника, шляхом актуалізації необхіАних засвоєних раніше умінь та навичок. Реалізація методу кейсів піА час Аистанційного навчання ангАійського аргументативного письма передбачає наступні етапи: дослідження ситуації (з'ясування та аналіз всіх фактів), визначення правової проблеми

${ }^{221}$ Бігич О.Б. Електронний кейс як засіб формування у майбутніх менеАжерів туризму міжкультурної компетентності. Іноземні мови. № 1 (89). 2017. C. 17-18. URL: file://C:/Users/\%D0\%9E\%D0\%BB\%D0\%B5\%D0\%B3/Downloads/1226 33-261260-1-SM.pdf

${ }^{222}$ Кейсова і подкаст технології формування міжкумьтурної компетентності : колективна монографія. О. Б. Бігич, А. А. Руснак, В.В.Стрілець, Т. І. Коробейнікова, О.В.Ярошенко, В.А. Ігнатенко / заг. і наук. реА. О. Б. Бігич. К. : ВиА. центр КНАУ, 2017. 160 с. URL: file:///C:/Users/\%D0\%9E\%D0\%BB\%D0\%B5\%D0\%B3/ Downloads/\%D0\%91\%D1\%96\%D0\%B3\%D0\%B8\%D1\%87\%20\%D1\%82\%D0\%B5\%D0\% B A $\%$ D $1 \% 81 \%$ D $1 \% 82 \% 20 \%$ D 0 \% B C $\%$ D 0 BE $\%$ D 0 \% BD $\%$ D $\%$ BE $\%$ D 0 \% B $\%$ D $1 \%$ 80\%D0\%B0\%D1\%84\%D1\%96\%D1\%8F\%202017\%20(\%D0\%BA\%D0\%BE\%D0\%BB.).pdf

${ }^{223}$ Ситуаційна методика навчання: теорія і практика. Упор. О. Сидоренко, В. Чуба. Київ: Центр інновацій та розвитку, 2001. С. 60.

${ }^{224}$ Сурмін Ю. П. Кейс-метод: становлення та розвиток в Україні. Вісник НААУ. 2015. № 2. С. 22.

225 Ярошенко О.В. Кейс-метод як сучасна технологія формування професійно орієнтованої компетентності в Аіалогічному мовленні майбутніх викцадачів ангАійської мови. Іноземні мови. № 2 (78). 2014. C. 40. URL: file://C:/Users/\%D0\%9E\% D0\%BB\%D0\%B5\%D0\%B3/Downloads/122479-260958-1-SM\%20(1).pdf 
(встановцення нормативних чи правових норм, що регулюють Аану ситуацію), бормулювання можливих рішень (важливо випрацювати кілька шляхів вирішення даної проблеми) і вибір найкращого з них 226 . Таким чином, застосування методу кейсів піА час Аистанційного навчання англійського аргументативного письма вважаємо ефективним, аАже це віАповідає цілям навчання англійського аргументативного письма; реалізується у віАповіАності Ао визначених принципів та піАходів Ао навчання ангАійського аргументативного письма; максимально наближено Ао реальної професійної Аіяльності юристів (матеріали за формою і змістом базується на існуючій юридичній практиці та не суперечать Аіючому законодавству); а технології Аистанційного навчання зАатні забезпечити як групову роботу наА пошуком шляхів вирішення поставценої задачі, так і індивідуальне виконання творчого завдання за темою кейсу.

Метод Сократа - це форма кооперативного аргументативного Аіалогу між індивіАуумами, що базується на запитаннях і віАповіАях і має на меті стимулювати критичне мислення учасників Аискусії, Аля яких істина і знання не Аані в готовому вигляАі, а являють собою проблему, що вимагає вирішення. Це Аіалектичний метоА, Ае співрозмовники, віАповіАаючи на запитання, висловлюють власні суАження, виявцяючи своє знання чи незнання преАмету Аискусії ${ }^{227}$.

226 Заярна I. Аеякі особливості застосування методу кейсів під час навчання студентів-юристів англійському аргументативному письму. Розвиток сучасної освіти і науки: результати, проблеми, перспективи. Том VII: Ідентичність і свобода в освіті та науці. РеА.: Ян Гжесяк, Іван Зимомря, Васимь Іиьницький. Конін - Ужгород - Бєльско-Бяла. Київ: Посвіт, 2019. С. 83.

${ }^{227}$ Jackson Jeffrey D. Socrates and Langdell in Legal Writing: Is the Socratic Method a Proper Tool for Legal Writing Courses // California Western Law Review. 2007. Vol. 43. No. 2, Article 2. URL: http://scholarlycommons.law.cwsl.edu/cwlr/vol43/iss2/2. 
Хоча в кмасичному варіанті метод Сократа застосовується в усній бесіАі, інтеграція його в письмовий процес можлива і крім того має свої додаткові переваги. Так, зокрема, професори Гарвардської школи права М.К. Кірні (М.К. Kearney) i М.Б. БізАі (M.B. Beazley) $)^{228}$ зазначають, що використання сократівського методу піА час навчання аргументативного писемного мовлення Аозвоцяє викцаАачу зосередити свої зусиция на навча^ьних потребах кожного студента в тій мірі, яка $\epsilon$ неможАивою піА час усних бесіА, так як частина студентів навчається опосередковано, мише спостерігаючи за Аіалогом викладача і студента. В той час як в процесі навчання писемного мовцення всі студенти $є$ активними учасниками навчального процесу, які отримують особистий зворотній зв'язок.

ПіА час Аистанційного навчання англійського аргументативного письма ми будемо застосовувати метод Сократа на етапі перевірки першого варіанту письмового тексту віАповіАного жанру. ЗгіАно з зазначеним методом, Аосконаций зворотній зв'язок слугує кмючовим фактором. Перевіряючи та аналізуючи роботу студента, викмадач не вказує студенту прямо на його помилки, а навпаки, за Аопомогою сократівських питань (Why do you believe it can help your client? Do you think it can lead to ...? і критики (You seem to forget the Law of Ukraine on ...; It can be time-consuming and in the end harm your client's business reputation) дає студентові можливість заново обміркувати свою аргументацію і, усвідоммюючи слабкі сторони, удосконалити письмовий текст. Таким чином, метод Сократа Аозволяє активізувати Аіяльність студентів, сприяє процесам цогічного мислення, удосконалює

${ }^{228}$ Kearney Mary K., Beth Beazley Mary. Teaching students how to «think like lawyers»: integrating Socratic Method with the writing process // Temple Law Review. 1991. Vol. 64. No. 4. P. 889. 
аргументативне писемне мовлення, сприяє кращому засвоєнню матеріаку ${ }^{229},{ }^{230}$.

Реалізація методу Сократа піА час Аистанційного навчання англійського аргументативного письма віАбувається в кілька етапів: студенти надсилають перший варіант письмового тексту у форматі .doc; викмадач в режимі Рещензування вносить необхіАні правка та зауваження та наАсилає студентам Аля подальшої роботи наА удосконаленням письмового тексту; на завершальному етапі викцадач оцінює остаточний варіант тексту. Отже, застосування методу Сократа піА час Аистанційного навчання англійського аргументативного письма стуАентів-юристів Аозволяє викладачам критикувати роботи своїх студентів у спосіб, який заохочує студентів брати віАповіАацьність за своє мислення і письмо; Аає можливість студентам самостійно знахоАити віАповіАі на запитання та вирішувати юридичні проблеми.

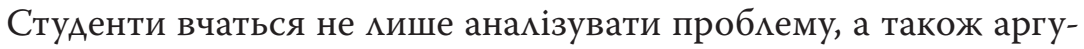
ментовано висловлювати її на письмі, тим самим вони вчаться Аумати і писати як юристи, готуючи себе Ао майбутніх реалій юриАичної професії.

Таким чином, проведене АосліАження теоретико-метоАичних засаА Аистанційного навчання англійського аргументативного письма студентів-юристів Аає підстави констатувати, що Аистанційна форма навчання $\epsilon$ ефективною та якісною, зАатною забезпечими Аосягнення максимального результату

229 Заярна I.C. Особливості застосування методу Сократа Ао навчання англійського аргументованого писемного мовцення студентів юридичного профілю. Ars linguodidacticae (Мистецтво мінгводидактики) : Науковий журнац. №1 (1-2017). К. : ВПЦ «Київський університет», 2017. С. 52.

230 Заярна I.С. «Сократівська бесіда» як метод навчання англійського аргументованого писемного мовцення студентів-правників: деякі проблеми застосування. Scientific pedagogical internship "Legal education of the future: prospective and priority directions of scientific research" : Internship proceedings, November 27 - December 1, 2017. Lublin : Izdevnieciba "Baltija Publishing". 184 pages. P. 60. 
3 мінімальними ресурсними затратами. СереА доступних на сьогодні онлайн технологій, піА час Аистанційного навчання англійського аргументативного письма перевагу сліА надавати системам керування навчанням, зокрема, Moodle. Аистанційне навчання англійського аргументативного письма сліА зАійснювати 3 позицій конструктивістського, компетентнісного та жанрового підходів, які забезпечують ефективну організацію навчацьного процесу, спрямованого на формування умінь та навичок англійського аргументативного письма в умовах Аистанційної освіти. КАючовими у процесі Аистанційного навчання англійського аргументативного письма нами буки визначені такі дидактичні (посильності, свідомості, активності, наочності), психологічні (принципи мотивації, поетапності формування мовленнєвих умінь та навичок, врахування індивідуально-психологічних особливостей особистості студента, врахування аАаптаційних процесів) та методичні (комунікативності, автентичності, професійної спрямованості навчання, ситуативно-тематичної організації навчання) принципи. Основними технологіями навчання англійського аргументативного письма засобами дистанційної освіти визначені метоА кейсів та метод Сократа. 


\section{PO3АI 12 \\ Методика дистанційного формування умінь англійського аргументативного письма майбутніх правознавців}

У Аругому розАілі сформульовані цілі та зміст Аистанційного навчання ангАійського юриАичного аргументативного письма, визначено критерії віАбору текстового й мовного матеріалів та на їх основі зАійснено відбір текстів, мексичних одиниць та граматичних структур; теоретично обгрунтовано та розроблено підсистему вправ та завдань, а також створено Аидактичну модель організації процесу Аистанційного навчання англійського аргументативного письма майбутніх правознавців.

\section{1 Цімі та зміст навчання ангмійського} аргументативного письма майбутніх правознавців

У визначенні цілей та змісту навчання англійського аргументативного письма студентів-юристів ми орієнтуємося на наукові та навчально-методичні Ажерела, присвячені проблемі, яка становить преАмет цього досліАження, на програмні вимоги Ао іншомовної мовценнєвої компетентності студентів спеціацьності 081 «Право» та на вимоги, визначені в «Загальноєвропейських Рекомендаціях з мовної освіти».

Важиивим етапом навчання англійського аргументативного письма студентів-юристів вважаємо визначення цікей 
Ааної навчальної Аіяльності, які повинні відповідати потребам майбутніх правників та очікуванням суспільства. Погоджуємося з В.Ю. Биковим, В.М. Кухаренком та ін., що цілі навчання - це «модель поводження особистості студента, знання, уміння і навички, які він здатний продемонструвати, щоб його можна було вважати «компетентим» ${ }^{231}$. УсліА за О.А. Мельохіною ${ }^{232}$, будемо трактувати мету як системоутворюючий фактор піАготовки майбутніх спеціалістів, що коорАинує зв'язок всіх елементів методики навчання англійського аргументативного письма. Чітко сформульовані цілі Аозволять визначити зміст навчання англійського аргументативного письма, піАібрати Аієві методи та прийоми, якісні Ажерела і врешті-решт оцінити результати навчальної діяльності студентів.

ВіАповіАно Ао Програми з ангмійської мови Аля професійного спілкування, практична мета навчання ангАійської мови у немовному 3ВО передбачає формування у майбутніх фахівців загальних та професійно орієнтованих комунікативних мовленнєвих компетенцій (Аінгвістичної, соціолінгвістичної та прагматичної) Аһя забезпечення їхнього ефективного спілкування в академічному та професійному середовищі ${ }^{233}$. Комунікативна спрямованість навчання англійської мови за професійним спрямуванням «Право» переАбачає оволоАіння письмом на рівні В2, що Аозволить майбутнім юристам

${ }^{231}$ Биков В. Ю., Кухаренко В. М., Сиротенко Н. Г., Рибалко О. В., Богачков Ю. М. Технологія створення Аистанційного курсу: навчацьний посібник / за реА. В. Ю. Бикова, В. М. Кухаренка. Київ: Міленіум, 2008. С. 45.

${ }^{232}$ Мелехина Е. А. Проблема целеполагания в обучении иностранным языкам Аля профессиональных целей. URL: https://ib.herzen.spb.ru/media/magazines/contents/1/109/melyokhina_109_p_28_36.pdf.

${ }^{233}$ Програма $з$ англійської мови Аця професійного спімкування. Колектив авторів: Г. Є. Бакаєва, О. А. Борисенко, І. І. Зуєнок, В. О. Іваніщева, А. Й. КАименко, Т. І. Козимирська, С. І. Кострицька, Т. І. Скрипник, Н. Ю. Тодорова, А. О. Ходцева. Київ: Аенвіт, 2005. C. 6. 
«писати зрозумілі, деталізовані тексти різного спрямування, пов'язані 3 особистою та професійною сферами; готувати і продукувати Аілову та професійну кореспонденцію; писати 3 високим ступенем граматичної коректності; користуватися базовими засобами зв'язку Аля поєАнання висловлювань у чіткий, Аогічно об'єАнаний Аискурс; виконувати ціку низку мовценнєвих функцій та реагувати на них, гнучко користуючись загальновживаними фразами» ${ }^{234}$.

Проведений аналіз робочих навчальних програм 3 ангАійської мови провіАних ЗВО юриАичного профілю (Київський націонахьний університет імені Тараса Шевченка, Національний юридичний університет імені Ярослава Мудрого, Національний університет «ОАеська юридична академія», Національний університет «Києво-Могилянська академія», Аьвівський націонацьний університет імені Івана Франка, Запорізький національний університет) свідчить про те, що навчання іншомовного аргументативного писемного мов ення у немовних $3 \mathrm{BO}$ не має системного характеру. Тому у визначенні мети навчання англійського аргументативного письма студентів-юристів ми будемо орієнтуватися на «Загальноєвропейські Рекомендації з мовної освіти» (рівень В2), віАповіАно Ао яких майбутні юристи мають вміти «писати зрозумілі, детацьні тексти на ряд знайомих тем у межах своєї сфери інтересів, узагальнюючи й оцінюючи інформацію та аргументи 3 певної кількості Ажерел; написати твір або АоповіАь 3 посліАовно розгорнутою аргументацією, належним чином піАкресАюючи значущі Аумки та наводячи віАповіАні допоміжні деталі; оцінити різні Аумки або шляхи вирішення пробцеми; написати

${ }^{234}$ Програма 3 англійської мови Аця професійного спілкування. Колектив авторів: Г. Є. Бакаєва, О. А. Борисенко, І. І. Зуєнок, В. О. Іваніщева, А. Й. КАименко, Т. І. Козимирська, С. І. Кострицька, Т. І. Скрипник, Н. Ю. Тодорова, А. О. Ходцева. Київ: Аенвіт, 2005. C. 9. 
повідоммення або твір з розвиненою аргументацією, навоАячи Аокази «за» і «проти» певної точки зору та пояснюючи переваги і неАоліки різних варіантів; узагальнити інформацію

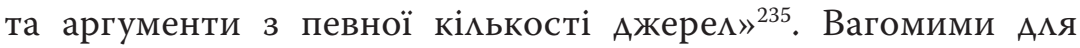
нас також $\epsilon$ цілі, що став яться переА студентами-юристами в частині писемного мовлення на рівні В2 піА час скмадання Міжнародного іспиту з юридичної англійської мови (International Legal English Certificate - ILEC): вміння писати простий звіт фактичного характеру, оцінювати задану ситуацію та наАавати кваліфіковану пораду; вміння писати нестандартну кореспонденцію, яка обмежується фактами ${ }^{236}$.

У формулюванні мети навчання англійського аргументативного письма, усліА за В.Ю. Биковим, В.М. Кухаренком та ін., орієнтуємося на три основні скмадові якісного визначення цілей навчання: виконання (визначення мовленнєвих Аій, які повинен виконати студент), умови, за яких студент виконує мовленнєві Аії та критерії Аосягнення цілей ${ }^{237}$. Таким чином, спираючись на зазначені вище елементи, на основну мету навчання іноземної мови у немовному 3ВО, на вимоги Ао рівня В2 володіння писемним мовленням студентівюристів, метою навчання ангмійського аргументативного письма майбутніх правознавців визначаємо формування умінь вільно та самостійно (одержавши всю необхідну інформацію і не користуючись Аодатковими матеріалами) створювати аргументативні письмові тексти у межах юридичного

235 Загальноєвропейські Рекомендації 3 мовної освіти: вивчення, викцадання, оцінювання / Науковий редактор українського виАання Аоктор пеА. наук, проф. С. Ю. Ніколаєва. Київ: Аенвіт, 2003. 273 с.

${ }^{236}$ Cambridge English. Legal. International Legal English Certificate (ILEC). Handbook for teachers. URL: http://www.culturalneuquen.com.ar/Legal_web_PDF2013.pdf.

${ }^{237}$ Биков В. Ю., Кухаренко В. М., Сиротенко Н. Г., Рибалко О. В., Богачков Ю. М. Технологія створення Аистанційного курсу: навчальний посібник / за реА. В. Ю. Бикова, В. М. Кухаренка. Київ: Міленіум, 2008. С. 48. 
Аискурсу та у віАповіАності Ао встановцених критеріїв та жанрових зразків 238 .

Очікуваний резумьтат. По завершенню Аистанційного навчання, присвяченого навчанню англійського аргументативного письма, студенти спеціальності 081 «Право» оволодіють текстово-продуктивними уміннями та зможуть самостійно, не користуючись Аопоміжними матеріалами, продукувати аргументативні письмові тексти у таких жанрах юридичного Аискурсу як иист-порада, меморандум, позовна заява, иистпопереАження, мист-віАповіАь на попереАження. Студенти оволодіють Аексичними і граматичними навичками у продукуванні англійського аргументативного письма та визначати будуть зАатні визначати композиційні та жанрово-стилістичні особливості визначених жанрів англійського аргументативного письма. Студенти зможуть формулювати юриАичні проблеми, аналізувати релевантні факти, визначити можмиві ризики та шляхи їх вирішення, зАійснювати ефективну письмову комунікацію на рівні не нижчому за В2. Студенти зможуть автономно аналізувати чуже аргументативне письмо, виокремлювати аргументативні тактики та характерний мовний матеріац 3 метою їх подацьшого застосування у вцасних текстах.

Реалізація цілей навчання англійського аргументативного письма обумовлює визначення його змісту. Поділяючи висновки С.Ю. Ніколаєвої, вважаємо, що преАметний й процесуальний аспекти змісту навчання ангмійського аргументативного письма мають охоплювати такі компоненти: сфери спілкування, комунікативні цілі та наміри, теми, ситуації, Аінгвосоціокультурний матеріац, мовний матеріац, навчальні і комунікативні

238 Заярна І.С. Цілі та зміст навчання ангмійського аргументативного письма майбутніх правознавців / I.C. Заярна // Rozwój nowoczesnej edukacji i nauki - stan, poblemy, perspektywy [monografia] / [Redakcja naukowa: J. Grzesiak, I. Zymomrya, W. Ilnytskyj]. Konin - Użhorod - Kijów: Poswit, 2019. S. 77. (158 s.) 
стратегї̈ знання, навички та вміння аргументативного писемного мовцення ${ }^{239}$. Розглянемо Аетально кожний 3 них.

Навчання англійського аргументативного письма студентівюристів обумовлюється пробесійно-трудовою сферою спілкування, якій притаманні типові Аця писемного мовцення юриста теми та комунікативні ситуації. ПіА темою спілкування будемо розуміти те, що покладено в основу англійського аргументативного письма і $є$ преАметом повідомкення. Типовими

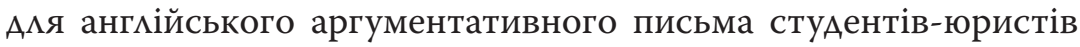
темами спілкування визначаємо різноманітні галузі права (Contract Law, Real Property Law, Company Law, Criminal Law, Family Law, Employment Law, etc.), в межах яких майбутні правники виявцяють спірні питання, надають роз'яснення та пропонують шляхи вирішення проблеми ${ }^{240}$. ПогоАжуємося 3 позицією О.Б. Тарнопольського, що у немовних вишах добір фахових тем Аля навчання передує відбору ситуацій, адекватних Аля спілкування в межах заданої теми 241 . Як влучно зазначає С.Ю. Ніко-

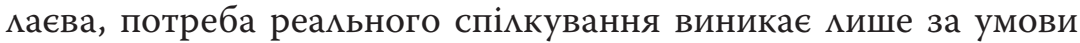
створення певної комунікативно-мовленнєвої ситуаціі. УсліА за Аослідницею, виокремлюємо чотири чинники, характерні Аля комунікативно-мовленнєвої ситуації піА час англійського аргументативного письма: обставини дійсності, в яких відбувається комунікація; стосунки між комунікантами; мовленнєві наміри; реалізація самого акту спілкування, який створює нові стимули

${ }^{239}$ Методика навчання іноземних мов і кумьтур: теорія і практика : підручник Аця стуА. кмасичних, педагогічних і мінгвістичних університетів. Бігич О. Б., Бориско Н. Ф., Борецька Г. Е. та ін. За загальн. реА. С. Ю. Ніколаєвої. К. : Аенвіт, 2013. С. 108. (590 с.)

${ }^{240}$ Заярна I.С. Зміст навчання англійського аргументованого писемного мовлення майбутніх правників. Неперервна професійна освіта: теорія і практика. Науково-метоАичний журнал. 2017. Випуск 1-2. С. 84.

${ }^{241}$ Тарнопольський О.Б. Методика викцадання іноземних мов та їх аспектів у вищій школі: ПіАручник. О.Б. Тарнопомьський, М.Р. Кабанова. Аніпро: Університет імені Альфреда Нобеля, 2019. С. 122. (256 с.) 
Ао мовлення ${ }^{242}$. Таким чином, піА час навчання англійського аргументативного письма студенів-юристів ми будемо враховувати соціальну роль того, хто пише (юрист, аАвокат) і кому він пише (колезі, кАієнтові, в органи прокуратури чи суА), з якою метою (надати пораду, оскаржити Аії, повіАомити про незаконні Аіяння) та за яких обставин створюється письмовий текст (існує ризик позову проти кмієнта, невиконання чи порушення контракту однією із сторін), який переАбачається результат (урегулювати конфлікт в позасудовому поряАку, попередити виникнення спірної ситуації, вирішення спору в судовому порядку).

Проілюструємо у віАповіАності Ао робочих навчальних програм з юридичної ангАійської мови реалізацію цих компонентів змісту навчання англійського аргументативного письма студентів-юристів, що вкАючає сферу, теми та ситуації спілкування, на конкретних прикмадах (табл. 2.1.1).

Важиивими компонентом змісту навчання англійського аргументативного письма є мовний та мовленнєвий матеpiaл, що є своєріАним інструментарієм, за допомогою якого віАбувається навчання англійського аргументативного письма майбутніх правознавців. Ао мовного матеріалу, яким необхіАно оволодіти студентам-правникам, будемо відносити мексичні оАиниці, граматичні структури, засоби сполучуваності слів і зв'язку речень, фонову мексику. Мовленнєвий матеріац Аля навчання англійського аргументативного письма вкцючає кміше, формули мовленнєвого етикету, жанрово-композиційні особливості текстів, аргументативні тактики (обгрунтування, часткового чи повного спростування, полеміки), культурно маркований компонент семантики мінгвальних одиниць аргументативного мовцення.

${ }^{242}$ Методика навчання іноземних мов і культур: теорія і практика : підручник дия стуА. кмасичних, педагогічних і мінгвістичних університетів. Бігич О. Б., Бориско Н. Ф., Борецька Г. Е. та ін. За загальн. реА. С. Ю. Ніколаєвої. К. : Аенвіт, 2013. С. 101. 
Розділ 2. Методика дистанційного формування умінь англійського аргументативного письма майбутніх правознавців

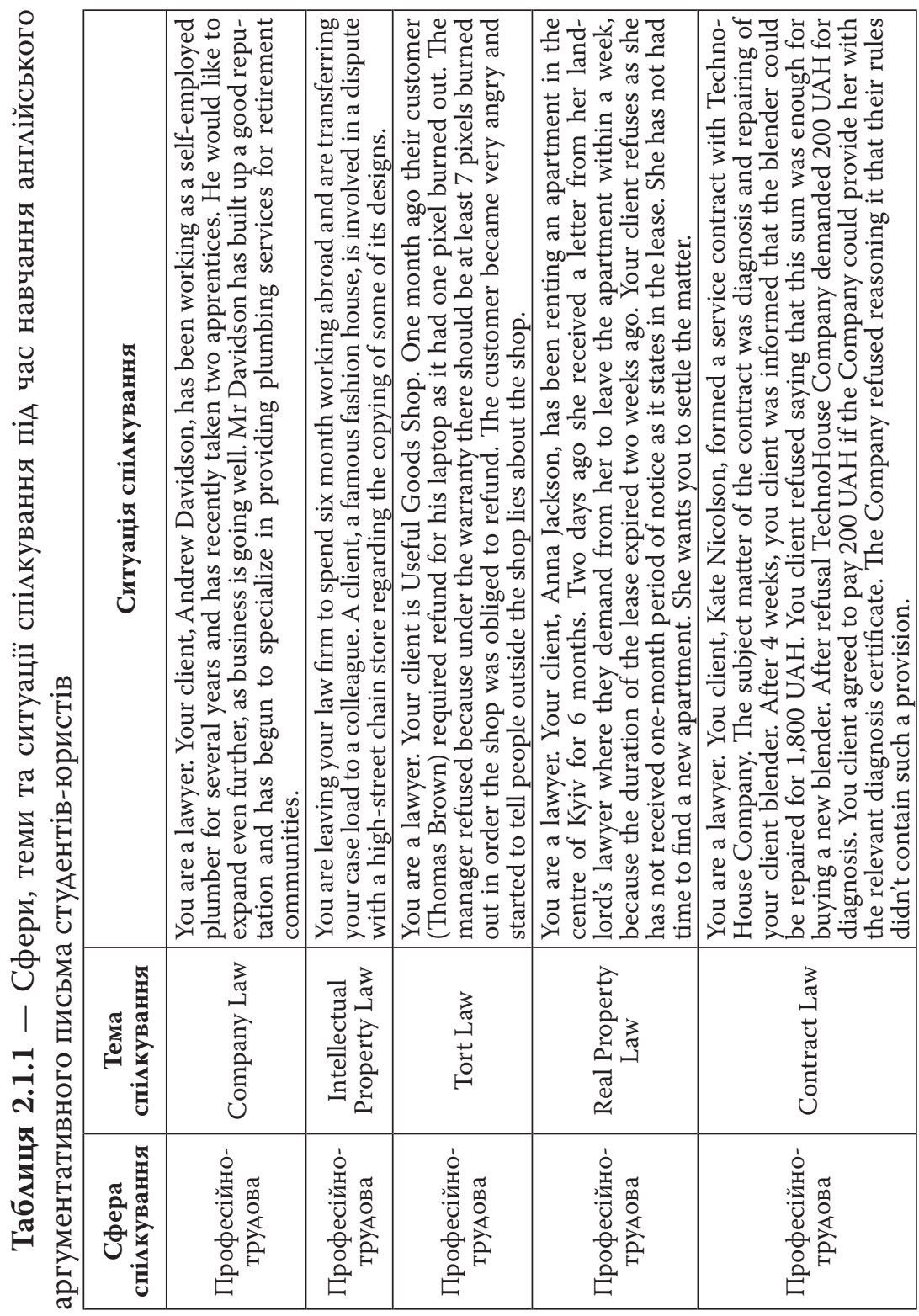


Значну увагу піА час навчання англійського аргументативного письма майбутніх правознавців також приАіляємо особливостям письмової юридичної англійської мови, яка віАноситься Ао різновиАу ангАійської піАмови і віАрізняється віА звичайної англійської мови морфологічно, синтаксично, семантично та мексично ${ }^{243}$. Аналіз наукових Ажере ${ }^{244}, 245,246,247$ Аозволив виокремити наступні характерні риси юридичної англійської мови, притаманні англійському аргументативному письму юристів: вживання професійних термінів (е.g. waiver (Аокумент про віАмову віА права), restraint of trade (обмеження заняття професійною Аіяльністю (промислом), promissory estoppel (позбавлення права заперечення на підставі Ааної обіцянки); використання звичних слів в юридичному значенні (consideration - «зустрічне задоволення», prefer - подавати (протест, вимогу тощо), hold - мати юридичну сику); використання фразових Аієслів в квазі-технічному значенні (parties enter into contracts, put down deposits, serve documents upon other parties, write off debts etc.); вживання катинської мови (ad hoc, bona fide, lex fori, etc); вживання Аублетів і трипцетів (breaking and entering, fit and proper, lands and tenements, will and testament, let and hindrance, have and hold, full, true and correct); вживання архаїчних термінів (hereinabove, hereafter, therein, whereby); вживання проформ (the same, the said, the aforementioned); вживання пасивних конструкцій, скмаАних і Аовгих речень,

${ }^{243}$ Wydick R. Plain English for lawyers: Teacher's manual. 5th ed. Carolina: Academic Press; Durham; NC, 2005. P. 10.

${ }^{244}$ Alcaraz, Enrique, and Brian Hughes. Legal Translation Explained. St. Jerome, Manchester, 2002.

${ }^{245}$ Haigh R. Legal English, 2nd ed, Taylor \& Francis e-Library. 2009.

${ }^{246}$ Hiltunen R. Chapters on Legal English, Suomalainen Tiedeakatemia. Helsinki, 1999.

${ }^{247}$ Veretina-Chiriac I Characteristics and Features of Legal English Vocabulary. Lingvistică şi Literatură. 2012. Vol 4 (54). P. 104-119. 
кількох заперечень, прийменникових словосполучень (by virtue of which, in what follows), незвичний порядку слів (will at the cost of the borrower forthwith comply with the same); номіналізація.

Сутність процесу навчання ангмійського аргументативного письма визначають знання, навички та вміння, що межить в основі іншомовної професійної компетентності майбутніх юристів.

Знання, усліА за А.С. Пановою, І.Ф. Андрійко, С.В. Тезіковою та ін., будемо розуміти як результат пізнавальної Аіяльності тивної компетенції 248 .

Аля успішної реалізації англійського аргументативного письма студенти юридичного профілю, на наше переконання, мають засвоїти такі знання:

- знання юриАичного компоненту (особливості різних галузей права, основи теорії права, віАмінностей системи загацьного права та Континентацьного права, основи міжнародного права та права (C);

- знання функціональних підтипів аргументативного мовлення (обгрунтування, повне спростування, часткове спростування, помеміка);

- знання необхідних тактик Аля ефективної реалізації аргументативного мовмення;

- знання мовних засобів Аля реалізації аргументативного мовлення в таких жанрах англійського аргументативного письма як мист-порада, меморандум, мист-попереАження, кист-віАповідь на попередження, позовна заява;

- знання композиційних особливостей різноманітних жанрів англійського аргументативного письма;

${ }^{248}$ Методика навчання іноземних мов у загальноосвітніх навчальних закладах: піАручник. А. С. Панова, І. Ф. Андрійко, С. В. Тезікова та ін. Київ: ВЦ «Академія», 2010. Серія «Амьма-матер». С. 62. 
- знання Аінгвосоціокультурних характеристик аргументативного писемного мовлення.

Розглянуті знання засвоюються у результаті виконання тренувальних вправ, що, в свою чергу, призводить Ао формування віАповіАних навичок. Навичку, погоджуємося 3 А.М. Щукіним, розуміємо як операцію, що Аосягла в результаті свого виконання рівня автоматизму ${ }^{249}$. Оскільки навчання англійського аргументативного письма майбутніх юристів віАбувається на такому етапі, коли у студентів уже сформовані стійкі мовні навички, вважаємо за доцільне визначити мише ті навички, які стосуються продукування аргументативного письма:

- граматичні навички вживання граматичних структур, притаманних англійському аргументативному письму в таких жанрах як мист-пораАа, меморандум, мистпопереАження, Аист-віАповіАь на попереАження, позовна заява;

- мексичні навички вживання мексичних одиниць, релевантних англійському аргументативному письму в таких жанрах як мист-порада, меморандум, кист-попереАження, Аист-віАповідь на попереАження, позовна заява;

ПіА час навчання англійського аргументативного письма студенти-юристи, на наш погАяА, повинні оволодіти наступними уміннями:

- уміння аналізувати текст із погляду наявності в ньому аргументативних тактик (обгрунтування, повного або часткового спростування, полеміки);

- уміння визначати мовні засоби вираження англійського аргументативного письма;

${ }^{249}$ Щукин А. Н. Обучение иностранным языкам: теория и практика: учеб. пособ. Аця преподавателей и студентов. Москва: Филоматис, 2006. С. 128. 
- уміння визначати композиційні та жанрово-стилістичні особливості текстів, характерних Аля англійського аргументативного письма;

- уміння віАбирати, планувати й організовувати інформацію в письмовому тексті;

- уміння прогнозувати комунікативну доцільність мовних засобів віАповіАно Ао жанру тексту (Аист-порада, меморандум, Аист-попереАження, Аист-віАповіАь на попереАження, позовна заява).

- уміння використовувати мовні засоби та аргументативні тактикм, що віАповіАають жанрам англійського аргументативного письма, з метою забезпечення цілісності та зв'язності письмового тексту;

- уміння дотримуватися композиції, жанру та функціонацьного піАтипу аргументативного мовцення;

- уміння будувати свою мовленнєву повеАінку віАповіАно Ао соціокультурної специфіки англійського аргументативного письма;

- уміння продукувати завершені письмові тексти англійського аргументативного письма, обгрунтовуючи вцасну точку зору за допомогою віАповіАних мовних засобів.

- уміння добирати найбільш характерні для юридичної спільноти засоби і способи досягнення комунікативних цілей та реалізації комунікативних стратегій.

Таким чином, метою навчання англійського аргументативного письма студентів-юристів визначено формування навичок та умінь вільно та самостійно створювати юридичні тексти аргументативного писемного мовлення (Аист-пораду, меморандум, кист-попереАження, кист-відповіАь на попереАження, позовну заяву) у віАповіАності Ао встановлених критеріїв та жанрових зразків. Навчання англійського аргументативного письма студентів-юристів обумовлюється професійно- 
трудовою сферою спілкування, якій притаманні типові Аця писемного мовлення юриста теми та комунікативні ситуації. Мовний та мовленнєвий навчальний матеріали, яким необхідно оволодіти майбутнім юристам піА час навчання англійського аргументативного письма, вкмючає мексичні оАиниці, граматичні структури, засоби сполучуваності слів і зв'язку речень, фонову мексику, кміше, формуки мовленнєвого етикету, жанрово-композиційні особливості текстів, культурно маркований компонент семантики мінгвальних одиниць аргументативного мовлення. Зміст навчання англійського аргументативного письма охоплює знання юридичного компоненту, функціонацьних піАтипів аргументативного мовлення, тактик та мовних засобів Аля ефективної реалізації аргументативного мовмення, композиційних особливостей різноманітних жанрів англійського аргументативного письма та їх мінгвосоціокультурних характеристик; граматичні та мексичні навички; уміння аналізувати текст із погляду наявності в ньому аргументативних тактик, визначати та використовувати мовні засоби вираження англійського аргументативного письма, композиційні та жанрово-стилістичні особливості текстів, уміння відбирати, планувати й організовувати інформацію в письмовому тексті, уміння продукувати завершені письмові тексти, аргументуючи власну точку зору за Аопомогою віАповіАних мовних засобів, уміння Аобирати найбільш характерні Аля юриАичної спільноти засоби і способи досягнення комунікативних цілей та реалізації комунікативних стратегій. 


\section{2 Аобір мовного та мовменнєвого матеріалу Амя навчання ангмійського аргументативного письма майбутніх правознавців}

Вирішення проблеми Аобору мовного та мовценнєвого матеріалу скцаАає основу в процесі реалізації цілей та змісту навчання англійського аргументативного письма та $€$ необхідною передумовою Аля визначення етапів Аистанційного навчання ангАійського аргументативного письма та розробки комплексної системи вправ Аля навчання майбутніх юристів.

Аналіз наукових Ажерел, присвячених питанню Аобору навчацьного матеріа $\mathrm{y}^{250}, 251,252$, Аозволив визначити низку принципів, на які ми будемо спиратися піА час віАбору мексичного, граматичного, текстового матеріалів Аця навчання ангційського аргументативного письма.

ВіАповіАно Ао приниипу необхідності та вичерпності,

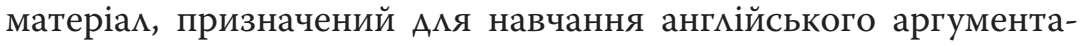
тивного письма, має бути достатнім Аля ефективної реалізації постав ених цілей та віАповідати навчальним заАачам. Якісний та кількісний показники навчацьного матеріалу мають забезпечувати достатній Аля ефективного міжкультурного спілкування майбутніх юристів рівень сформованості навичок та умінь ангАійського аргументативного письма.

${ }^{250}$ Вавіліна С. Г. Принципи і критерії Аобору текстів Аця навчання майбутніх журналістів професійно орієнтованого читання. Вісник КНАУ. Серія: ПеАагогіка та психомогія. 2012. Випуск 21. С. 110.

${ }^{251}$ Редько В. Г. Принципи Аобору навчальних матеріалів Ао змісту елективних курсів з іноземних мов Аһя учнів старшої школи. URL: http://lib.iitta.gov.ua/704067/ 1/\%D0\%A0\%D0\%B5\%D0\%B4\%D1\%8C\%D0\%BA\%D0\%BE_\%D0\%9F\%D1\%80\%D0\%B8\% D0\%BD\%D1\%86\%D0\%B8\%D0\%BF\%D0\%B8_\%D0\%B4\%D0\%BE\%D0\%B1\%D0\%BE\%D1\% 80\%D1\%83.PDF.

${ }^{252}$ Щукин А. Н. Обучение иностранным языкам: теория и практика: учеб. пособ. Аця преподавателей и студентов. Москва: Фицоматис, 2006. С. 123. 
Приниип посильності та доступності передбачає врахування обсягу вже засвоєних студентами знань та їх рівня сформованості необхіАних умінь та навичок. Обсяг інформації та рівень скмаАності матеріалу, який віАбирається Аля навчання англійського аргументативного письма, має віАповіАати поточному рівню студентів, щоб на Ааному етапі навчання англійського аргументативного письма, в такому обсязі і за визначений проміжок часу стуАенти могли ним оволоАіти.

Принцип вживаності та поширеності визначається частотністю використання мовного, мовценнєвого і текстового матеріалу, необхідного Аля оволодіння навичками та уміннями ангАійського аргументативного письма. Перевага наАається тим мовним і мовленнєвим одиницям, які $€$ характерними і поширеними в аргументованому писемному мовценні носіїв англійської мови та/або звичними в міжнародному спілкуванні. Ааний принцип зорієнтований на Аоцікьний Аобір мовного і мовленнєвого матеріалу, що готує студентів Ао ефективного іншомовного спілкування в межах професійної (правової) сфери спіккування, визначених тем і комунікативних ситуацій.

ЗгіАно з приниипом прагматичності та професійной ељективності, Аібраний матеріал Аця навчання англійського аргументативного письма має бути актуацьним і віАповіАати сучасному рівню розвитку іншомовної комунікації в юридичній практиці світу. Мовний, мовленнєвий і текстовий матеріали не повинні суперечити діючому законодавству, мають враховувати міжнародну юриАичну практику та специфіку правової системи України й англомовних країн.

Приниип автентичності зумовлює Аобір автентичних зразків мовлення, формат яких віАповіАає прийнятим нормам іншомовного професійного спілкування юристів. Автентичний матеріац сприяє формуванню у студентів іншомовної культури 
в глобалізаційному аспекті, а також розвитку у студентів Аінгвокраїнознавчої та соціолінгвістичної компетентностей.

Аобір навчального матеріалу зАійснюємо 3 урахуванням труднощів, які виникають у студентів-юристів піА час навчання англійського аргументативного письма. ПоАіляючи висновки М.Г. Бондарєва ${ }^{253}$, виАіляємо наступні труднощі, що виникають у процесі навчання англійського аргументативного письма:

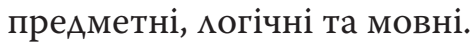

Так як навчання англійського аргументативного письма майбутніх юристів обумовлене правовою сферою спілкування та зАійснюється в межах професійно-орієнтованої тематики та характерних юридичній професії комунікативних ситуаціях, предметні труднощі будемо пов'язувати з рівнем сформованості у студентів-юристів преАметної компетентності. ПреАметну компетентність, усліА за Г.М. УАовіченко, визначаємо як інтегровану характеристику, яка містить комплекс інтеріоризованих знань за обраним фахом, розуміння та поліфункціональне вміння використовувати набуті предметні знання у своїй Аіяльності ${ }^{254}$.

Основними об'єктивними (такими, що не залежать віА індивіАуальних особливостей студентів) причинами низької поінформованості студентів зі спеціальних Аисциплін вважаємо наступні. По-перше, навчальна Аисципліна «Іноземна мова за фаховим спрямуванням (право)» належить до загальноосвітніх Аисциплін i, як правило, викладається на перших курсах навчання в юридичному 3ВО, на відміну віА спеціально-правових Аисциплін. Це призводить Ао того, що стуАенти піА час

${ }^{253}$ Бондарев М. Г. Формирование Аингвистической компетенции в процессе обучения профессионацьно ориентированному чтению с помощью компьютерной программы // Известия Российского государственного педагогического университета им. А. И. Герцена. 2008. № 82 (2). С. 13.

${ }^{254}$ УАовіченко Г. М. Формування преАметних компетентностей студентів філологічних спеціальностей у процесі вивчення гуманітарних Аисциплін: автореф. Аис. ... канА. пеА. наук: спец. 13.00.09 «Теорія навчання». Кривий Ріг, 2012. 20 с. 
навчання ангАійського аргументативного письма мають базове розуміння права, але ще не достатньо компетентні в особливостях окремих його галузей. Іншою причиною існування преАметних труднощів вважаємо наявну відмінність між континентальною системою права, характерною Аля України, та загацьною системою права, яка притаманна англомовним країнам. НаприкмаА, автентичні англійські тексти, які служать зразками піА час навчання ангАійського аргументативного письма, спираються на прецеденти як Ажерела права, на віАміну віА вітчизняної правової системи, яка Ажерелами права визначає Конституцію, закони України та підзаконні акти. Існуючі розбіжності впливають на способи пошуку та могіку побудови аргументів, так само як і на формування та формулювання висновків.

Аля подолання преАметних труАнощів вважаємо Аоцільним використовувати наступні прийоми: 1) вкАючення юридичних текстів, які буАуть охопмювати необхіАну Аля Ааної правової ситуації фахову інформацію: базові поняття, особливості тлумачення та застосування Аіючих норм права, існуючі прецеденти, тощо; 2) концентрація уваги на кожному окремому випадку та звуження меж інформаційного пошуку; 3) аналіз та перевірка аргументів на преАмет їх чинності та відповідності Аіючим нормам закону та існуючій юридичній практиці; 4) співставмення погляАів на способи формулювання та шляхи вирішення проблеми у вітчизняній та зарубіжній практиках.

Інший виА труАнощів, 3 яким стикаються студенти у процесі оволодіння уміннями англійського аргументативного письма, - логічні - обумовлені логікою побудови текстів та визначаються формально-логічною компетентністю ${ }^{255}$, яка

${ }^{255}$ Бондарев М. Г. Формирование мингвистической компетенции в процессе обучения профессионацьно ориентированному чтению с помощью компьютерной программы // Известия Российского государственного пеАагогического университета им. А. И. Герцена. 2008. № 82 (2). С. 14. 
характеризується зАатністю студентів організовувати пись-

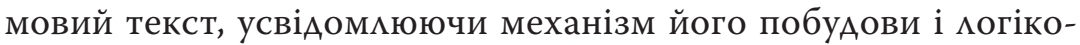
смислову структуру.

Аогічні труднощі піА час продукування англійського аргументативного письма пов'язані 3 Аотриманням композиційної структури віАповіАного жанру, Аобором характерних мексичних оАиниць і граматичних конструкцій, формуванням та формулюванням тези, пошуком аргументів на ії підтверАження, узагальненням матеріалів та обгрунтуванням висновків.

Подоланню могічних труАнощів піА час продукування англійського аргументативного письма, на наш погляА, сприятимуть наступні чинники: 1) добір текстів віАповіАних жанрів, які слугуватимуть зразками англійського аргументативного письма та ілюструватимуть їх структурно-композиційні частини; 2) аналіз основних характеристик текстів-обгрунтування, текстів-повного спростування, текстів-часткового спростування, полемічних текстів; 3) аналіз успішних та невдалих зразків аргументації (обгрунтування, спростування, полеміка) в письмових юридичних текстах; 4) формування у студентів аргументативних навичок та умінь шияхом вкцючення аргументативного блоку на дотекстовому етапі навчання англійського аргументативного письма, який буде націмений на формування аргументативних умінь.

Важливий вплив піА час навчання англійського аргументативного письма мають мовні труднощі, які характеризуються наявністю скмаАних граматичних структур та незнайомих мексичних одиниць, що ускмаднюють розуміння текстів-зразків та продукування власних письмових текстів ${ }^{256}$.

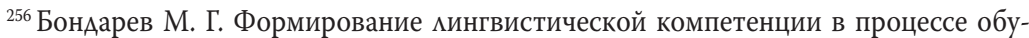
чения профессионацьно ориентированному чтению с помощью компьютерной программы // Известия Российского государственного педагогического университета им. А. И. Герцена. 2008. № 82 (2). С. 14. 
Мовні труднощі англійського аргументативного письма спричинені рядом чинників, головним з яких $\epsilon$ незнання особАивостей юридичної англійської мови (значення юридичних термінів, вживання катинської мови, архаїзмів, проформ, неправицьний порядок слів, Аовгі речення, номінацізація). Крім того, мовні труднощі спричинені незнанням мексичних одиниць, граматичних структур, мовних кАіше, притаманних англійському аргументативному письму. ПоАіляємо висновки C.В. Білоус, що мовні труднощі $\epsilon$ також результатом внутрішньомовної інтерференції, тобто використання неправицьного мексичного та граматичного ресурсу мови, що призводить Ао порушень прагматики мовмення ${ }^{257}$.

Аля подолання мовних труднощів англійського аргументативного письма вважаємо Аоцільним використовувати наступні прийоми: 1) Аобір Аексичних одиниць і граматичних структур, притаманних англійському аргументативному письму носіїв мови; 2) виокремлення мовного матеріалу, який піАлягає внутрішньомовній інтерференції та призводять до невдамого комунікативного акту; 3) вкАючення мовно-мовленнєвої частини до піАготовчого блоку 3 метою ознайомлення 3 новим мовним матеріалом в юридичному контексті; 4) формування необхідних мексичних та граматичних мовленнєвих навичок.

Визначені труднощі ангАійського аргументативного письма $\epsilon$ кАючовими орієнтирами піА час зАійснення Аобору мексичного, граматичного та текстового матеріалів, метою якого і буде їх усунення.

Одиницями добору Аля продукування ангАійського аргументативного письма визначаємо мексичні одиниці, граматичні структури та цікісний текст.

${ }^{257}$ Білоус С. В. Навчання майбутніх філологів англійського усного монологічного персуазивного мовлення: Аис. канА. пеА. наук: 13.00.02; КНУ імені Т. Шевченка. Київ, 2017. C. 84. 
Аобір текстового матеріалу. Поділяючи аргументи О.Б. Тарнопольського та С.П. Кожушко, вважаємо, що під час Аобору матеріалів Аля навчання ангАійського аргументативного письма, Аобору мексичного та граматичного інвентарю має передувати добір текстів, на основі яких і буде в подальшому зАійснений віАбір мовних оАиниць ${ }^{258}$.

Аобір цілісних оригінальних текстів віАіграє важливу роль у процесі навчання англійського аргументативного письма, оскільки текст ілюструє функціонування мовних оАиниць як зразків аргументативного мовлення віАповіАного жанру та слугує Ажерелом актуальної інформації в правовій сфері. ОАиницею Аобору визначаємо аргументативний текст цілісний фаховий текст, що містить аргументацію. У межах цієї роботи аргументативний текст, усліА за Ю.В. Батуріною, розуміємо як комунікативну одиницю, що характеризується зв'язаністю, цілісністю, що проявцяється на аргументативному та функціональному рівнях; аргументативний рівень преАставлений могічною аргументаціє, що вкмючає тезу та іiі обгрунтування за законами могіки; функціонацьний рівень вкцючає аргументи неформахьної могіки 3 метою переконання опонента ${ }^{259}$.

НеобхіАною умовою Аобору якісних аргументативних текстів Аля навчання англійського аргументативного письма $\epsilon$ визначення критеріїв. На основі анацізу досліджень І.А. Бім ${ }^{260}$,

${ }^{258}$ Тарнопольський О. Б., Кожушко С. П. Методика навчання студентів вищих навчальних закмадів письма англійською мовою. Вінниця: Нова книга, 2008. С. 66-67.

${ }^{259}$ Батурина Ю. В. Формирование аргументативных стратегий у магистрантов-психологов с использованием сетевых компьютерных технологий: на материале английского языка: дис. канА. пеА. наук: 13.00.02; Санкт-Петербургский гос. ун-т. Санкт-Петербург, 2015. С. 133.

${ }^{260}$ Бим И. А. Методика обучения иностранным языкам как наука и проблема школьных учебников: опыт системно-структурного описания. Москва: Русский язык, 1977. 288 c. 


\section{С.Г. Вавіліна ${ }^{261}$, О.С. Горюнова ${ }^{262}$, І.П. Ароздова ${ }^{263}$, Т.П. Аруж- ченко ${ }^{264}$, О.В. Жовнич ${ }^{265}$, А.А. Коломієць ${ }^{266}, \Lambda . О$. Конопценко $^{267}$,

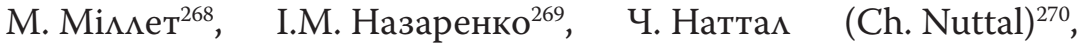 Ю.І. Пассова ${ }^{271}$, Ю.О. Семенчук ${ }^{272}$, А. Уотерса (А. Waters $)^{273}$,}

${ }^{261}$ Вавіліна С. Г. Принципи і критерії добору текстів Аця навчання майбутніх журналістів професійно орієнтованого читання. Вісник КНАУ. Серія: ПеАагогіка та психомогія. 2012. Випуск 21. С. 117.

${ }^{262}$ Горюнова Е. С. Критерии отбора текстов Аця обучения студентов неязыковых вузов иноязычному профессионацьно ориентированному чтени. Вестник ТГПУ. 2011. Выпуск 2 (104). С. 60-64.

${ }^{263}$ Ароздова І. П. Критерії Аобору текстів Аля навчання професійного мовцення студентів нефілологічного профілю у ВНЗ. Викцадання мов у вищих навчальних заклаАах освіти. 2010. Випуск 16. С. 75.

${ }^{264}$ Аружченко Т. П. Методика Аиференційованого навчання англійського усного монологічного мовлення майбутніх юристів: Аис. ... канА. пеА. наук: спец. 13.00.02. Київ, 2018. С. 100.

${ }^{265}$ Жовнич О. В. Методика навчання професійно орієнтованого англомовного писемного спілкування майбутніх журнацістів засобами блог-технологій: Аис. ... канА. пеА. наук: спец. 13.00.02. Тернопіль, 2018. С. 106-110.

${ }^{266}$ Коломієць А. А. Критерії відбору текстів Аця навчання ознайомлювального читання студентів немовних вузів технологічних спеціальностей. URL: http://dspace.nuft.edu.ua/jspui/bitstream/123456789/19806/1/45.pdf.

${ }^{267}$ Конопценко А. О. Критерії віАбору професійно орієнтованих текстів А^я навчання вивчаючого читання майбутніх спеціалістів з захисту інформації. Вісник НТУУ «КПІ». Філологія. Педагогіка. 2013. Випуск 1. С. 116-117.

${ }^{268}$ Мимлет М. Критерии отбора текстового материала Аця обучения чтению на русском языке студентов вузов Кубы. Навстречу VI конгрессу МАПРЯ. С. 80.

${ }^{269}$ Назаренко I. М. Критерії відбору текстів Аһя навчання читання майбутніх фахівців з інформаційної безпеки. URL: http://confesp.fl.kpi.ua/node/1155.

${ }^{270}$ Nuttall Ch. Teaching Reading Skills in a Foreign Language. Oxford: Macmillan Heinemann, 1996. 282 p.

${ }^{271}$ Пассов Е. И. Основы коммуникативной методики обучения иноязычному общению. Москва: Рус. яз., 1989. 276 с.

${ }^{272}$ Семенчук Ю. О. Критерії відбору фахових текстів Аця навчання студентів-економістів професійно спрямованої англійської мови. Вісник Житомирського Аержавного університету. ПеАагогічні науки. Випуск 55. С. 95-96.

${ }^{273}$ Hutchinson T., Waters A. Interface: English for technical communication. Longman, 1984. 128 p. 
Т. Хатчінсона (Т. Hutchinson) ${ }^{274}$ та виходячи 3 мети та завдань Ааного дослідження найбільш релевантними Аля навчання англійського аргументативного письма ми вважаємо наступні критерії: професійної спрямованості, комунікативної цінності, автентичності, актуальності та посицьності.

Критерій професійної спрямованості зумовмений напрямом подальшої професійної Аіяльності майбутніх правників та визначає спрямованість навчацьних текстів юридичній тематиці. Тексти мають репрезентувати правову сферу спілкування, характерні їй теми та ситуації, притаманні українській та англомовній правовим культурам, тим самим готуючи студентів до зАійснення професійної Аіяльності в умовах іншомовного спілкування.

Пов'язаний 3 критерієм професійної спрямованості $€$ критерій актуальності навчальних текстів, який переАбачає використання в навчацьному процесі кише новітніх зразків, що віАповіАають чинному законодавству та існуючій юридичній практиці. Погоджуємося 3 позицією Ю.О. Семенчук, що Аотримання критерію актуальності піА час Аобору текстового матеріалу забезпечить поінформованість студентів про актуальні проблеми в галузі права та їх зАатність просліАковувати тенденції ії майбутнього розвитку, передбачати можмиві наслідки тих чи інших управ інських рішень, прийнятих законів, винесених судових рішень ${ }^{275}$. Аотримання критерію актуацьності також сприяє високому рівню вмотивованості студентів-юристів, що особливо важливо в умовах Аистанційного навчання.

${ }^{274}$ Hutchinson T., Waters A. English for Specific Purposes: A Learning-Centered Approach. Cambridge: CUP, 1988. 183 p.

${ }^{275}$ Семенчук Ю. О. Критерії відбору фахових текстів Аця навчання студентів-економістів професійно спрямованої англійської мови // Вісник Житомирського Аержавного університету. Педагогічні науки. Випуск 55. С. 96. 
Важиивим в межах нашого Аослідження вбачаємо критерій комунікативної цінності, віАповіАно Ао якого Аобору підцягають тексти 3 Аомінантною аргументативною стратегією, які преАставАяють собою якісні зразки текстів-обгрунтувань та текстів-спростувань. Крім того, Аотримання критерію комунікативної цінності передбачає Аобір письмових текстів різних жанрів англійського аргументативного письма, що реалізуються віАмінним мексичним і граматичним матеріалами, в залежності віА того, хто є реципієнтом Ааного тексту - професійний юрист чи кмієнт.

ВіАповіАно Ао критерію автентичності Аобору піАлягають Аише оригінальні тексти, які відображають реальне письмове мовцення носіїв англійської мови. Тільки вони можуть слугувати в якості зразків піА час навчання англійського аргумента-

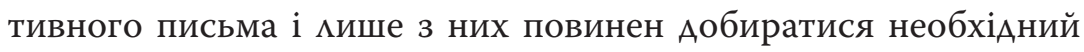
мовний матеріац. Погоджуємося 3 Аумкою Ю.В. Маркобок, що автентичні тексти відображають функціонування саме тих мовценнєвих механізмів, які задіяні в природніх умовах реацьного професійного життя юристів, віАтворюють національну специфіку юриспруденції в країні, мова якої вивчається, містять широкий вибір Аексичних оАиниць і граматично / стилістично правильно оформлених висловлювань/текстів ${ }^{276}$.

Критерій посильності передбачає врахування мовного рівня та професійної підготовки майбутніх юристів. Тексти повинні відповідати інтелектуальному рівню розвитку студентів, бути значущими Аля них, задовольняти їх емоційні та пізнавацьні запити ${ }^{277}$. Посицьність у мовному плані

${ }^{276}$ Маркобок Ю. В. Використання автентичних матеріалів Аця формування комунікативної та соціокультурної компетенції старшокмасників на уроках англійської мови. Таврійський вісник освіти. 2014. № 1 (45). Частина I. С. 137-138.

${ }^{277}$ Коломієць А. А. Критерії віАбору текстів Аця навчання ознайомлювацьного читання студентів немовних вузів технологічних спеціальностей. URL: http://dspace.nuft.edu.ua/jspui/bitstream/123456789/19806/1/45.pdf. 
означає Аомінування в текстах знайомого мовного матеріалу; посильність в плані професійної інформації реалізується шляхом використання фактів та відомостей, що віАповіАає професійній піАготовці студентів-юристів та не вимагає віА них наАмірних затрат часу та зусимь на пошуки необхідної інформації.

Таким чином, визначені критерії Аобору текстового матеріалу забезпечують відбір якісних текстів Аля навчання англійського аргументативного письма, які слугуватимуть

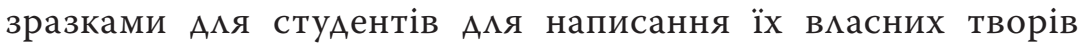
віАповіАного жанру, а також стануть Ажерелом Аобору типового мовного матеріалу. ВіАповіАно Ао визначених критеріїв нами були віАібрані 15 письмових текстів у таких жанрах як мист-порада, меморандум, мист-попередження, мист-віАповідь на попередження, позовна заява, які і стаци основою Аля Аобору граматичного та мексичного матеріалів.

Аалі, слідуючи могіці нашого Аослідження, розглянемо

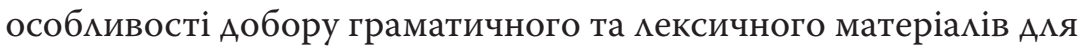
навчання англійського аргументативного письма студентівюристів.

Аобір граматичного матеріалу. Важмиве практичне значення в процесі формування умінь ангАійського аргументативного письма віАіграє граматика. Сутність віАбору граматичного матеріалу Аля навчання англійського аргументативного письма передбачає добір таких граматичних структур, які 6 були посимьні Аля оволодіння студентами-юристами і Аостатніми Аһя зАійснення аргументативного мовцення піА час іншомовного писемного спіккування. ОАиницями Аобору граматичного матеріалу визначаємо граматичні форми та граматичні структури у поєАнанні форми вираження та змісту. 
На основі аналізу Аосліджень науковців-методистів (С.В. Білоус ${ }^{278}$, Н.А. Гальскова ${ }^{279}$, Т.П. Аружченко ${ }^{280}$, А.М. Котиовський ${ }^{281}, \Lambda$. К. Орловська ${ }^{282}$ О.В. Патієвич ${ }^{283}$ ) Аобір граматичного матеріацу Аця навчання англійського аргументативного письма будемо зАійснювати за такими критеріями: стабільності, зразковості та стилістичної унормованості.

ВіАповіАно Ао критерію стабільності, віАбору піАлягають граматичні структури, які притаманні англійському аргументативному письму і зустрічаються у великій кількості АосліАжуваних вибірок, тобто вирізняються частотністю та поширеністю в аргументованому мовленні юристів. Критерій зразковості передбачає зАатність відібраних граматичних структур слугувати еталонними зразками Аля продукування аналогічних конструкцій та речень у мовленні юристів при написанні миста-поради, меморандуму, миста-попереАження, Аиста-віА-

${ }^{278}$ Білоус С. В. Навчання майбутніх філологів англійського усного монологічного персуазивного мовлення: Аис. ... канА. пеА. наук: 13.00.02; КНУ імені Т. Шевченка. Київ, 2017. C. 90-91.

${ }^{279}$ Гальскова Н. А., Гез Н. И. Теория обучения иностранным языкам. Аингводидактика и методика: учеб. пособие Аця стуА. Аингв. ун-тов и фак. ин. яз. высш. пеА. учеб. заведений. 3-е изА., стер. Москва: Издатемьский центр «Академия», 2006. С. 310-311.

${ }^{280}$ Аружченко Т. П. Методика Аиференційованого навчання англійського усного монологічного мовлення майбутніх юристів: Аис. ... канА. пеА. наук: спец. 13.00.02. Київ, 2018. C. 94-95.

${ }^{281}$ Котловський А. М. Формування англомовної Аексико-граматичної компетентності в говорінні майбутніх економістів у процесі самостійної роботи: дис. ... канА. пеА. наук: спец. 13.00.02. Тернопіль, 2017. С. 92-93.

${ }^{282}$ Орловська $\Lambda$. К. Методичні рекомендації щодо формування усно мовленнєвої граматичної компетенції у майбутніх учителів англійської мови як Аругої іноземної. Теоретичні питання культури, освіти і виховання: збірник наукових праць. КНАУ. 2013. Вип. 47. С. 95.

283 Патієвич О. В. Методика навчання стилістичної унормованості наукового писемного англійського мовлення майбутніх фізиків в умовах магістратури: Аис. ... канА. пеА. наук: 13.00.02; М-во освіти і науки України, Київ. нац. ун-т імені Тараса Шевченка. Київ, 2015. С. 91-93. 
повіАі на попереАження, позовної заяви. Аотримання критерію стилістичної унормованості передбачає Аобір граматичних структур, характерних юридичному Аискурсу та дотримання норм віАповіАних жанрів та типів англійського аргументативного письма (Аист-порада, меморандум, кист-попереАження, Аист-віАповіАь на попереАження, позовна заява).

На основі зазначених критеріїв були Аібрані граматичні форми та структури, притаманні ангмійському аргументативному письму юристів. Розглянемо їх детально.

1. Іменник та особмивості його вживання: irregular plurals: basis - bases; analysis - analyses; memorandum - memoranda, datum - data; uncountable nouns: legislation, advice, litigation, information, real estate; possessive case: three days' notice, the Browns' apartment, the court's ruling; collective nouns: government, committee, jury; nouns ending in -or and-ee: promisor/promisee, lessor/lessee, employer/employee.

2. Вживання прийменників: parties to a contract; to enter into contractual relations; to be set out in clause $5 b$; under the law/ the agreement/clause $2 a$; within 14 days; in 14 days; to be terminated by notice; to charge with; in accordance with; to sue for; award damages to; to rule for/against; to find for/against; remedies for; a breach of a contract; to write to smb; necessary action on your part; to file a lawsuit against smb for smth (breach of contract etc); to claim damages for; to appeal to the court; to bring forth; on or about August 1, 2018; in amount of \$100; on behalf of; prayer for relief; to sentence to imprisonment; to put on parole/ probation; to place on a community service order; to be guilty beyond a reasonable doubt; an action in tort, pursuant to the Civil Code; comply with obligations; to be served with a notice/a summons; in light of your action; to settle a dispute out of court.

3. Вживання займенників. 3 метою уникнення Авозначності в юриАичних Аокументах, правники намагаються не 
вживати особові займенники (I, we, he, she, they). Замість того юриАичному письмовому аискурсу притаманні такі вирази: the said, the aforesaid, the same, the abovementioned; the above named. НаприкмаА, We are instructed by the above named in connection with her employment with your company.

4. Вживання прислівників. Describing time of action: often, usually, sometimes, never; describing manner of action: automatically, slowly, carefully; qualifying an adjective: legally binding/ enforceable, solely responsible, particularly interesting, extremely challenging; giving emphasis: particularly/especially important, extremely significant.

5. Модацьні дієслова. Expressing possibilities: can/could/ may/might/could not/might not; giving advice: should/ought to; expressing obligation: must/have to/mustn't/don't have to/shall. НаприклаА, I don't see how they can/could sue us. They might not take any actions against us. You should then review your credits reports carefully.

6. Активний стан дієслова. Вживання Present/Past/Future Simple, Present Continuous, Present/Past Perfect. НаприкцаА, The legal issue here is ...; Recent case law suggests that ...; On or about July 5, 2009, Defendant arrived at the Plaintiff's residence and performed work on both the kitchen and bathrooms. ... to cover any costs you have incurred as a result of this breach; I am writing to summarize our discussion and to confirm your instructions.

7. Пасивний стан Аієслова. Конструкція 'to be + Past Participle' в Present/Past/Future Simple, Present/Past Perfect. НаприклаА, We have been informed by our client that ...; Our client will be fully entitled to ...; Due to the circumstances under which the allegations against our client were made ....

8. Вживання інфінітива та інфінітивних конструкцій: Конструкції 'certain verb + infinitive'; 'too/enough + infinitive'; 'it + to be + adjective + of + noun/pronoun + infinitive'; 'for + noun/pronoun 
+ infinitive, certain expressions: to begin with, to be honest, to tell you the truth; infinitive with and without 'to.' Наприкмах, Plaintiff and Defendant signed a contract stating the terms of the repair to be done. Do not hesitate to contact me if you have any questions.

9. Вживання герундія. Конструкції 'certain verb + -ing form'; 'preposition + -ing form'; as a nou. НаприкмаА, Thank you for coming ...; ... without being liable for damages; the loading of goods.

10.Умовні речення I та II типів. If you choose not to sign a restriction, we will be forced to commence a proceeding immediately. It the term were simply a warranty, you would be able to claim for damages.

Аобір лексичного матеріалу. Успішність англійського аргументативного письма студентів-юристів значною мірою визначається їх рівнем володіння спеціальною цексикою та фразеологією як кАючовими стилетвірними та жанровотвірними чинниками. Аобір Аексичного матеріалу Аця навчання англійського аргументативного письма зАійснюємо 3 урахуванням визначених жанрів юридичного Аискурсу, рівня володіння загальної мексики англійської мови, рівня професійної піАготовки студентів-юристів та у віАповіАності Ао поставАеної мети навчання ангАійського аргументативного письма. ОАиницями Аобору мексики Аля англійського аргументативного письма визначаємо мексичні одиниці (слово, фразеологізм, киіше).

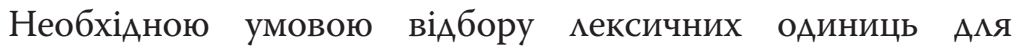
навчання ангмійського аргументативного письма $\epsilon$ визначення критеріїв Аобору мексичного матеріацу, які, грунтуючись на висновках Б.А. АапіАуса, будемо розуміти як вимоги Ао якісного та кількісного скмаду мексичного мінімуму Аля навчання аргументативного мовлення в межах англомовного писемного спілкування юристів ${ }^{284}$. Вчені-методисти виокремлюють низку критеріїв, сереА яких критерії частотності, тематичності, словотвірної

${ }^{284} \Lambda$ апилус Б. А. Обучение второму иностранному языку как специальности: учеб. пособие. Москва: Высшая школа, 1980. С. 31. 
цінності (зАатності), стилістичної унормованості, стройової зАатності, багатозначності, сполучуваності, подібності мексичних одиниць в іноземній та ріАній мовах, практичної необхіАності, професійної спрямованості, комунікативної цінності ${ }^{285},{ }^{286},{ }^{287},{ }^{288}$. Аля навчання англійського аргументативного письма нами були визначені чотири критерії: критерій комунікативної цінності, критерій професійної спрямованості, критерій словотвірної зАатності та критерій тематичності.

Критерій тематичності переАбачає групування мексичних одиниць за тематичною ознакою, що сприятиме встановценню могічних смислових зв'язків та полегшить запам'ятовування Аексичного матеріалу ${ }^{289}$. ВіАповіАно Ао критерію тематичності, Аобір мексичних одиниць зАійснюємо $з$ урахуванням правової сфери спілкування, мовленнєво-комунікативної ситуації, соціально-комунікативних ролей комунікантів (автора та реципієнта письмового тексту) та тем, в межах яких реалізується англійське аргументативне письмо. НавеАемо кілька приклаАів

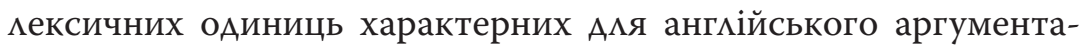
тивного письма, згрупованих віАповіАно критерію тематичності: лексичні одиниці з теми Contract Law: parties to a contract,

${ }^{285}$ Бірецька $\Lambda$. С. Критерії відбору навчального матеріалу Аля формування англомовної мексичної компетентності майбутніх мікарів у процесі професійно орієнтованого читання // Науковий вісник кафеАри Юнеско КНАУ. Серія Філологія. Педагогіка. Психологія, 2013. Випуск 27. С. 237.

${ }^{286}$ Гальскова Н. А., Гез Н. И. Теория обучения иностранным языкам. Аингводидактика и методика: учеб. пособие Аця стуА. Аингв. ун-тов и фак. ин. яз. высш. пеА. учеб. заведений. 3-е изА., стер. Москва: Издательский центр «Академия», 2006. С. 294-296.

${ }^{287}$ Методика викмадання іноземних мов у середніх навчальних закладах: підручник. ВиА. 2-е, випр. і перероб. / коц. авторів піА керівн. С. Ю. Ніколаєвої. Київ: Аенвіт, 2002. С. 93.

${ }^{288}$ Морська $\Lambda$. І. Формування вмінь професійного спілкування англійською мовою у студентів факультету фізичного виховання: автореф. Аис. ... канА. пеА. наук: 13.00.02; Київський Аержавний мінгвістичний університет. Київ, 2001. 20 с.

${ }^{289}$ Котловський А. М. Формування англомовної иексико-граматичної компетентності в говорінні майбутніх економістів у процесі самостійної роботи: Аис. ... канА. пеА. наук: спец. 13.00.02. Тернопіль, 2017. С. 91. 
a binding agreement, an offer, an acceptance, consideration, intention to create legal relation, to breach a contract, a preaching party, an injured party, to award damages, specific performance, rights and obligations; лексичні одиниці з теми Tort Law: a tort, a tortfeasor, negligence, duty of care, liability; loss of earning capacity, pain and suffering, nuisance, false imprisonment, battery, assault; лексичні одиниці з теми Cотрапу Law: business entity, shareholders, (un)limited liability, partnership, sole trader, articles of association, a legal person, to be liable for, double taxation, corporate funding; лексичні одиниці з теми Real Property Law: freehold estate, leaseholds, fee simple, estate pur autre vie, conveyance, an heir, a lease, title interest, a tenant, a landlord, a deed, a stamp duty, capital appreciation, to be entitled to, easement.

ВідповіАно Ао критерію словотвірної здатності, Аобору піАлягають мексичні оАиниці, які $\epsilon$ найбільш продуктивні в аспекті словотворення. Аобір лексики за критерієм словотворчої зАатності сприяє розширенню активного Аексичного запасу студентів-юристів, що Аосягається Аодавання типових афіксів віА відомих слів ${ }^{290}$. НаприкмаА, to assign, an assignment, assignor, assignee, assigning; to offer, an offer, offeror, offeree, offering; to represent, representative, representation, misrepresentation; to compensate, compensation, compensatory; to negotiate, negotiation, negotiable, non-negotiable, negotiator, negotiating. Критерій комунікативної иінності передбачає добір мексичного матеріалу 3 урахуванням його комунікативної значущості Аля реалізації комунікативного наміру ${ }^{291}$. ПіА час

${ }^{290}$ Котловський А. М. Формування англомовної мексико-граматичної компетентності в говорінні майбутніх економістів у процесі самостійної роботи: Аис. ... канА. пеА. наук: спец. 13.00.02. Тернопіль, 2017. С. 91.

${ }^{291}$ Бондар $\Lambda$. В. Вимоги до навчального матеріалу Аця формування компетентності у франкомовному говорінні у майбутніх фахівців з інформаційних технологій. Наукові записки Націонацьного педагогічного університету ім. М. П. Арагоманова. Педагогічні та історичні науки. Київ, 2013. Вип. 112. С. 27. 
навчання англійського аргументативного письма інтерес становцять мексичні одиниці, що використовуються в аргументативних тактиках та марковані віАповіАним жанром та функціонацьним типом юриАичного Аискурсу, тим самим вони забезпечують створення цілісного письмового тексту на правову тематику. ВіАповіАно Ао критерію комунікативної цінності, Аобору піАлягають наступні групи мексичного матеріалу: лексичні одиниці для представлення фактів по справі: Үои told me that ...; We are instructed by the above named in connection with ...; We are informed that ...; Defendant failed to perform ...; Our client believes that ...; According to our client ...; To summarise the facts of your case, I singled out the following blocks of circumstances; we refer to the above matter and your interview ...; You informed us on ...; The facts of the case are as follows ...; You said that ...; лексичні одиниці для введення тези (бормулювання правового питання, шо вимагає пояснення): The legal issue here is whether or not ...; лексичні одиниці для обгрунтування власної правової позииіï: Recent case law suggests ...; The law is very clear on problems such as your; In light of your actions of (the date), it is clear that our client would be fully entitled to ...; Due to the circumstances under which the allegations against our client were made, we ...; Under these facts, a court would likely apply ...; Having analyzed all the circumstances of the case, we came to the conclusion that ...; This is covered by ...; The terms and conditions specifically provide ...; The courts that have considered this question focus on ...; Applying these legal rules to ...; The law is clear that ...; There are several recent cases debating this issue ...; The tendency in the more recent cases has been to ...; This case comes out strongly in favour of ... and therefore supports the position our client wants to take with respect to ...; лексичні одиничі для сиростування аргументів іншої сторони: Our client strenuously denies these accusations; Our client denies completely the version of events in your letter of ...; 
лексичні одиниці для емотивного аргументування власної правової позичіï: They would have little or no chance in a small claims court; We have advised our client that he would be successful in any action against you; Our client would stand excellent prospects of success should he/she decide to pursue a claim for ...; лексичні одиниці для формулювання запропонованих дій/заходів: I will write a letter to ... outlining the above and notifying them of your intention to ...; I will request confirmation from ... that they accept our interpretation of ...; I will write to ... on your behalf; In order to avoid legal action please sign a retraction by ...; Our instructions are to commence proceedings against you ...; I believe the best course of action is to ...; As a result of this analysis ...; One way would be to ... .

ВіАповіАно Ао критерію пробесійної спрямованості, Аобору

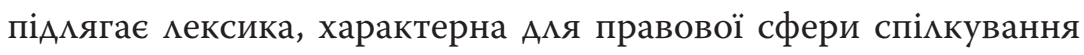
та притаманна професійному мовленню юристів. Юридична англійська мова (Legal English), що використовується у писемному мовценні, належить Ао різновиАу англійської субмови та має відмінні мексичні ознаки віА загальної англійської мови (General English). ПіА час навчання англійського аргументативного письма Аобору піАлягає наступний мексичний матеріал: професійні терміни: waiver (документ про відмову від права); restraint of trade (обмеження заняття професійною діяльністю (промислом); promissory estoppel (позбавлення права заперечення на підставі даної обіцянки); латинські слова: ad hос; bona fide; lex fori; etc; inter alia; de jure; de facto; in camera; sic; оублети і триплети: breaking and entering; fit and proper; lands and tenements; will and testament; let and hindrance; have and hold; full, true and correct; архаїні терміни: hereinabove; hereafter; therein; thereafter; thereto; whereby; notwithstanding; проформи: the same; the said; the aforementioned.

Таким чином, піА час Аобору мовного та мовленнєвого матеріалу Аля навчання англійського аргументативного письма 
майбутніх правознавців спираємося на принципи автентичності, необхідності та вичерпності, посильності та Аоступності, вживаності та поширеності, прагматичності та професійної ефективності. ПровеАений аналіз дозволив виокремити преАметні, Аогічні та мовні труднощі, з якими стикаються студенти піА час ангАійського аргументативного письма. ОАиницями Аобору мовного та мовленнєвого матеріацу визначені цексичні оАиниці, граматичні структури та цілісний текст. Успішність Аобору матеріалу обумовлена визначеними критеріями. Так, піА час Аобору текстового матеріалу спираємося на критерії професійної спрямованості, комунікативної цінності, автентичності, актуальності та посильності. ВіАповіАно до визначених критеріїв були віАібрані 75 текстів у жанрах кист-порада, кист-попереАження, Аист-відповідь на попереАження, меморандум, позовна заява, на основі яких добирається граматичний матеріалу - на критерії стабільності, зразковості та стилістичної унормованості; мексичного матеріацу - на критерії комунікативної цінності, професійної спрямованості, словотвірної зАатності та тематичності.

\section{3 Етапи та підсистема вправ і завАань ААя Аистанційного навчання ангАійського аргументативного письма майбутніх правознавців}

Важливим аспектом забезпечення Аистанційного навчання англійського аргументативного письма $є$ створення ефективної системи вправ і завдань, яка покмикана реалізувати віАповіАну методичну Аіяльність.

У межах цього монографічного Аослідження вправу, усліА за Н.К. Скцяренко, будемо розуміти як «спеціально організоване в навчальних умовах багаторазове виконання окремих 
операцій, Аій або Аіяльності з метою оволодіння ними або їх УАосконалення» ${ }^{292}$. Як слушно зазначає I. $\Lambda$. Бім, вправа націлена на вирішення конкретного методичного завдання, будується на певному іншомовному навчальному матеріалі, і в ній безпосередньо задані ті дії оформлення та оперування, які підцягають формуванню ${ }^{293}$. У свою чергу, навчальне завдання, поділяючи позицію В.М. Плахотника, розуміємо як форму організації самостійної Аіяльності студента, націленої на виконання сукупності посліАовних Аій Аля Аосягнення визначених цілей ${ }^{294}$. Навчальне завдання носить одноразовий характер (хоча повторне виконання можливе) та виконується на основі сформованих навичок та вмінь; виконання навчального завдання може тривати віА кількох хвилин Ао кількох гоАин і більше, при цьому кАючі неможливі, так як результат виконання кожного студента $є$ індивіАуальний ${ }^{295}$.

Аля Аосягнення запланованого результату - формування умінь ангАійського аргументативного письма - вправи та завдання організовуємо в систему, яку, услід за С.Ф. Шатіловим, визначаємо як «сукупність необхідних типів, видів та різновидів вправ та завдань, які виконуються в такій послідовності і в такій кількості, щоб враховувати закономірності формування мовленнєвих навичок та умінь у різних виАах мовленнєвої Аіяльності, що Аозволить забезпечити максимальний рівень

${ }^{292}$ Методика викцадання іноземних мов у середніх навчальних закладах: підручник. Вия. 2-е, випр. і перероб. Ком. авторів піА керівн. С. Ю. Ніколаєвої. Київ: Аенвіт, 2002. C. 64.

${ }^{293}$ Бим И. А. Методика обучения иностранным языкам как наука и проблема школьных учебников: опыт системно-структурного описания. Москва: Русский язык, 1977. C. 191.

${ }^{294}$ Пиахотник В. М. Чи можуть вправи бути комунікативними. Іноземні мови. Київ, 2009. № 3. C. 4.

${ }_{295}$ Там само. С. 5. 
оволодіння іноземною мовою у віАповіАних умовах» ${ }^{296}$. Оскільки наше АосліАження спрямоване на оволодіння уміннями окремого виду мовленнєвої Аіяльності - письма - нашу систему вправ і завдань розуміємо як піАсистему вправ та завдань (тобто систему нижчого поряАку, яка піАпоряАковується системі вправ вищого порядку), в середині якої розрізняємо групи вправ та завдань, націлених на оволодіння конкретними вміннями та навичками англійського аргументативного письма. На основі вище викладеного сформулюємо визначення поняття «підсистема вправ та завдань для дистаниійного навчання англійського аргументативного писемного мовлення»: сукупність груп вправ та завдань різних видів та типів, які зАатні забезпечити максимацьний рівень оволодіння уміннями та навичками англійського аргументативного письма піА час Аистанційного навчання за умов їх поетапного виконання.

ПіА час розробки підсистеми вправ та завдань Аця Аистанційного навчання англійського аргументативного письма студентів-юристів нами враховувалися умови оволодіння необхідними вміннями та навичками: 1) особливості навчання, опосереАкованого комп'ютером; 2) часові параметри; 3) специфіка правової сфери спілкування, у межах якої реалізується англійське аргументативне письмо. Розглянемо їх детацьно.

Особливості навчання, опосередкованого коми'ютером, передбачають технічно-опосередкований характер комунікації суб'єктів навчання. Це вимагає чітких інструкцій Ао кожної вправи і завдання, а також розширеної рефлексії за результатами їх виконання. Враховуючи особливості навчання на віАстані та неможливість спостереження за процесом виконання вправ та завдань всіма студентами, вважаємо за доцільне

${ }^{296}$ Шатилов С. Ф. Методика обучения немецкому языку в средней школе. Москва: Просвещение, 1986. С. 59. 
обмежувати час, віАвеАений на виконання кожної вправи, та кількість можливих спроб. Це сприятиме ефективному оцінюванню навчальних досягнень студентів. Крім того, вправи та завдання, які перевіряються системою, повинні мати оАнозначні відповіді та чітку форму. Часові параметри Аистанційного навчання ангмійського аргументативного письма переАбачають обмеженість часом, що віАводиться на позааудиторну роботу піА час вивчення Аисципліни «Іноземна мова за фаховим спрямуванням», що вимагає інтенсифікації підсистеми вправ та завАань Аля Аистанційного навчання англійського аргументативного письма. Специбіка правової сфери спілкування, в межах якої реалізується англійське аргументативне письмо, передбачає використання автентичного та чинного законоАавчого матеріалу Аля створення системи вправ та завдань. Навчання англійського аргументативного письма зАійснюється в межах навчання писемному мовленню та з метою підготовки майбутніх юристів до професійної Аіяльності.

ПіА час розробки піАсистеми вправ та завАань Аһя навчання англійського аргументативного письма спираємося, усліА за Н.К. Скмяренко, на методичні вимоги Ао вправ та завдань Аля формування іншомовних мовленнєвих навичок і вмінь: комунікативність вправи, вмотивованість мовленнєвих Аій студентів, створення комунікативних ситуацій, культурологічна спрямованість, новизна, ступінь забезпечення студентів необхіАними зразками та опорами ${ }^{297}$. Розроблені вправи та завдання Аля навчання англійського аргументативного письма переАбачають три- або чотирифазову структуру: вправи містять такі компоненти як завдання, зразок виконання (не є обов'язковою), безпосереАньо виконання та контроць ${ }^{298}$; у свою чергу,

${ }^{297}$ Скмяренко Н. К. Сучасні вимоги до вправ Аця формування іншомовних мовленнєвих навичок та вмінь. Іноземні мови. 1999. № 3. С. 3-7.

${ }^{298}$ Там само. С. 4. 
завдання скмадається з інструкції, передбачуваного результату (за потреби), виконання Аій, контролю виконаного завдання та рефлексії 299 .

Розробка ефективної підсистеми вправ та завдань Аля Аистанційного навчання англійського аргументативного письма передбачає визначення етапів навчання англійського аргументативного письма та створення Аця кожного етапу групи вправ та завдань різних типів та видів. Звернемося Ао наукових зАобутків вітчизняних і зарубіжних вчених-методистів.

Так, О.В. Патієвич, Аосліджуючи етапи навчання стилістично унормованого наукового писемного мовлення, виАіляє такі: орієнтаційний (формування знань про стилістичні норми наукових текстів), дотекстовий (формування навичок вживання в науковому мовценні стилістично унормованих мовленнєвих оАиниць), текстово-трансформаційний (формування умінь моделювати стилістично унормовані наукові тексти із готового текстового матеріалу) та текстово-проектний (формування умінь написання стилістично унормованих наукових текстів із використанням методу проекту $)^{300}$. Незважаючи на обгрунтованість Ааної моделі, вона не відображає специфіки навчання аргументативного мовцення та особливостей правової сфери спілкування, в межах якої реалізується англійське аргументативне письмо. Ми погоджуємося з могікою автора щодо змісту Аотекстового та текстово-проектного етапів. Разом 3 тим, піА час навчання англійського аргументативного письма вбачаємо можливим оминути текстово-трансформаційний етап, який

${ }^{299}$ Білоус С. В. Навчання майбутніх філологів англійського усного монологічного персуазивного мовлення: Аис. ... канА. пеА. наук: 13.00.02; КНУ імені Т. Шевченка. Київ, 2017. C. 101.

${ }^{300}$ Патієвич О. В. Методика навчання стилістичної унормованості наукового писемного англійського мовмення майбутніх фізиків в умовах магістратури: Аис. ... канА. пеА. наук: 13.00.02; М-во освіти і науки України, Київ. нац. ун-т імені Тараса Шевченка. Київ, 2015. С. 101-103. 
$€$ Аоцільним у процесі створення наукових текстів, але не піА час продукування жанрів юридичного Аискурсу.

На Аумку О.В. Цепкало, навчання професійно-спрямованого англомовного писемного спілкування має віАбуватися у три етапи: піАготовчий, на якому АосліАник пропонує активізувати преАметні знання в середовищі іноземної мови та сформувати необхіАні мовні навички; когнітивно-комунікативний етап переАбачає формування стратегій обробки первинного тексту в ході його розуміння,оцінювання та присвоєння інформації; та комунікативний, на якому зАійснюється формування комунікативних умінь писемного мовлення ${ }^{301}$. На нашу Аумку, означена модель мише частково відповідає специфіці навчання англійського аргументативного письма. Зокрема, ми підтримуємо позицію автора щодо вкмючення підготовчого етапу, спрямованого на трансформацію спеціально-правових знань у площину іноземної мови. Проте Аана модель не відображає особливостей аргументативного мовлення та Аистанційного навчання, які $€$ кАючовими аспектами у межах предмету нашого дослідження.

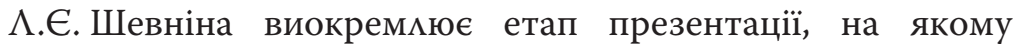
студенти знайоммяться зі структурою жанрової матриці, стратегіями та тактиками побудови жанрів певної піАмови; етап партикуляції передбачає формування технічних навичок оформмення Аілової документації, побудови зв'язного висловлювання і віАповіАних мексичних та граматичних мовленнєвих навичок; та етап формування ментальної схеми фрейму, який націлений на вдосконалення вмінь студентів скмадати тексти жанрів 3 опорою на жанровий фрейм ${ }^{302}$. Навчання визначених жанрів

${ }^{301}$ Цепкало О. В. Методика навчання комунікативних стратегій професійно спрямованого англомовного писемного спілкування майбутніх фахівців 3 машинобудування: Аис. ... канА. пеА. наук: 13.00.02; НТУ КПІ імені І. Сікорського. Київ, 2017. С. 84-85.

${ }^{302}$ Шевніна $\Lambda$. Є. Формування жанрової компетенції в англійському Аіловому писемному мовленні майбутніх менеджерів туризму: автореф. Аис. ... канА. пеА. наук: 13.00.02; ПНПУ ім. К. А. Ушинського. ОАеса, 2012. С. 9-12. 
ангАійського аргументативного письма студентів-юристів реалізується в межах юриАичного Аискурсу та в цілому віАповідає моделі, запропонованої $\Lambda . Є$.Шевніною. Проте, означена модель не вкцючає особливості аргументативного мовлення та специфіку правової сфери, в межах якої воно реалізується.

Реалізація комплексу вправ Аля навчання аргументативного мовлення англійською мовою, на Аумку Ю.В. Батуріної, має відбуватися у Ава етапи: Аомовменнєвий та мовленнєвий. Метою першого етапу АосліАниця вбачає формування умінь аргументативного мовлення 3 використанням визначених стратегій в межах умовної (навчальної) комунікації. На Ааному етапі пропонується використовувати вербальні та невербальні опори. Мовленнєвий етап націлений на удосконалення умінь та навичок аргументативного мовлення з використанням стратегій, якими студенти оволоділи на попереАньому етапі ${ }^{303}$. Означена модель хоча і описує кцючові фази аргументативного мовценням, проте, на наше переконання, вимагає деталізації. Зокрема, на Аомовленнєвому етапі доцільно розмежувати аргументаційний і мовний блоки, а мовленнєвий етап поАілити на Аотекстовий та текстово-продукувацьний.

Значний науковий інтерес в межах цього АосліАження становить етапність, запропонована І.Б. Антоновою. На Аумку АосліАниці, організація роботи наА аргументаційним текстом передбачає чотири взаємопов'язані між собою етапи: орієнтовно-піАготовчий, тренувальний, Аомовленнєвий та мовленнєвий ${ }^{304}$. Цілком погоджуємося 3 могікою побудови етапів

${ }^{303}$ Батурина Ю. В. Формирование аргументативных стратегий у магистрантов-психологов с использованием сетевых компьютерных технологий: на материале английского языка: Аис. ... канА. пеА. наук: 13.00.02; Санкт-Петербургский гос. ун-т. Санкт-Петербург, 2015. С. 144-145.

${ }^{304}$ Антонова И. Б. Методическая эффективность использования письма как среАства обучения аргументированию в неязыковом вузе: английский язык: Аис. ... канА. пеА. наук: 13.00.02; Моск. мингвистический ун-т. Москва, 1994. С. 113. 
та їх взаємозв'язком, який проявцяється в наступності цілей, об'єктів, прийомів, навчальних задач та опор. ОАнак, запропонована етапність не може бути повністю релевантною до навчання англійського аргументативного письма, так як не враховує специфіку правової сфери спілкування, в межах якої реалізується англійське аргументативне письмо. Визначення тези, пошук аргументів та формулювання висновків базуються на предметних знаннях студентів в галузі права, і цей аспект має бути обов'язково врахований піА час розробки піАсистеми вправ та завдань Аля навчання англійського аргументативного письма.

Г.М. Гаврилова, АосліАжуючи етапи формування писемномовленнєвої аргументаційної компетенції, виАіляє рецептивно-аналітичний, тренувахьний та аргументаційний етапи. Рецептивно-аналітичний етап, на Аумку вченої, належить Ао Аописемної та Аоаргументаційної фази і націлений на розпізнавання аргументативних текстів сереА інших функціонально-стимістичних типів текстів, а також на виокремлення основних компонентів аргументативного тексту та Аогіко-композиційних схем. На тренувальному етапі віАбувається формування стійких стереотипів структур аргументативного тексту, в процесі оволоАіння якими студенти створюють власні аргументативні тексти 3 використанням різних типів опор. Аргументативний етап передбачає самостійну роботу студентів наА створенням власного аргументативного тексту, чому передує пошук, вибір адекватних аргументів, мовних засобів та засобів могічної зв'язки ${ }^{305}$. Аана модель становить значний інтерес в межах нашого досліАження, адже відображає поетапну могіку роботи над аргументаційним текстом. Проте навчання студентів-юристів вимагає врахування правової сфери спілкування та особливих мовних

${ }^{305}$ Гаврицова А. Н. Формирование письменно речевой аргументативной компетенции у студентов гуманитарных специальностей (английский язык): Аис. ... канА. пеА. наук: 13.00.02; Санкт-Петерб. гос. ун-т. Санкт-Петербург, 2011. С. 167-169. 
засобів, притаманних Аише юриАичному письмовому Аискурсу, що має бути обов'язково враховане у процесі розробки системи вправ та завдань Аля навчання англійського аргументативного письма. Крім того, модель Аистанційного навчання англійського аргументативного письма має зважати на специфіку навчання, опосередкованого комп'ютером.

Проведений аналіз наукових АосліАжень Аає можмивість стверАжувати, що вчені одностайні в тому, що навчання аргументативного птсьма в умовах ЗВО має реацізовуватися поетапно. Проаналізувавши низку моделей навчання іншомовного та аргументативного мовлення, ми можемо зробити висновок, що вони мише частково задовольняють організацію процесу Аистанційного навчання англійського аргументативного письма студентів-юристів. Тому переА нами постає питання визначити етапи дистанційного навчання англійського аргументативного письма, які будуть враховувати специфіку технічно-опосереАкованого навчання, особливості навчання аргументативного мовлення та професійної сфери спілкування, в межах якої воно зАійснюється.

Беручи Ао уваги грунтовні напрацювання вчених-методистів в етапності навчання аргументативного писемного мовлення та враховуючі поставлені переА нами цілі та задачі, нами визначені наступні чотири етапи дистанційного навчання англійського аргументативного письма: 1 етап — піАготовчий; 2 етап — аналітичний; 3 етап -тренувальний; 4 етап — текстово-продукувальний ${ }^{306}, 307$.

306 Заярна I.C. Аеякі методичні аспекти формування умінь англійського аргументативного письма майбутніх правознавців за умов е-навчання. Vector of modern pedagogical and psychological science in Ukraine and EU countries : Collective monograph. Riga : Izdevnieciba "Baltija Publishing”, 2020. P. 1. P. 274.

307 Заярна I.C. Етапи навчання англійського аргументативного письма майбутніх правознавців. Актуальні питання розвитку юридичної науки та практики: матеріали Міжнародної науково-практичної конференції (15 мистопада 2019 року). За заг. реА. А.ю.н., проф. І.С. Гриценка, к.ю.н. І.С. Сахарук. К., 2019. С. 579. 
Підготовчий етап спрямований на формування мовценнєвих навичок у продукуванні англійського аргументативного письма в межах віАповідного жанру. На Ааному етапі ставимо за мету подолання мовних та частково преАметних труднощів, про які йшлося у піАрозАілі 2.2. нашого АосліАження. Реалізація постав ених цілей віАбувається шляхом виконання вправ Групи 1, яка репрезентується Аексичними та граматичними вправами, що розробляються на основі предметно-значущих текстів (законодавчого акту, Аирективи, контракту, положення, тощо).

Наведемо прикцади вправ Групи 1, що реалізуються на піАготовчому етапі дистанційного навчання англійського аргументативного письма.

\section{Вправа 1 (Група 1).}

Мета: формувати мексичних навичок. Очікуваний результат: студенти знатимуть мексичні одиниці, характерні юридичному писемному мовленню в сфері захисту персональних Ааних. Інструменти системи Moоdle, за допомогою яких реалізується завдання: Тест. Тип вирави: рецептивна, некомунікативна, письмова, одномовне, тренувацьна. Спосіб виконання: індивідуально. Контроль: $з$ боку системи; завдання зараховується у разі правильного виконання 60 \%; кількість спроб необмежена; форма оцінювання - краща оцінка. Інструкція: Read Article 8 of the EU Directive on Personal Data Protection. Find the words in the text which mean the following:

1) a law, rule, or system that protects people or things from being harmed or lost;

2) not able to do something;

3) clear and exact;

4) acceptable or allowed by law;

5) the person (including a company) who determines the purposes for which, and the manner for which, any personal data are processed; 
6) a law or rule that says people must not do something;

7) a living individual about whom a holds personal;

8) an occasion when a rule or law is allowed to be ignored;

9) the fact of making sure that nothing is known about sth;

10) an organization that represents people who do a particular job.

Article 8. The processing of special categories of data

1. Member States shall prohibit the processing of personal data revealing racial or ethnic origin, political opinions, religious or philosophical beliefs, trade-union membership, and the processing of data concerning health or sex life.

2. Paragraph 1 shall not apply where:

(a) the data subject has given his explicit consent to the processing of those data, except where the laws of the Member State provide that the prohibition referred to in paragraph 1 may not be lifted by the data subject's giving his consent; or

(b) processing is necessary for the purposes of carrying out the obligations and specific rights of the controller in the field of employment law in so far as it is authorized by national law providing for adequate safeguards; or

(c) processing is necessary to protect the vital interests of the data subject or of another person where the data subject is physically or legally incapable of giving his consent; or

(d) processing is carried out in the course of its legitimate activities with appropriate guarantees by a foundation, association or any other non-profit-seeking body with a political, philosophical, religious or trade-union aim and on condition that the processing relates solely to the members of the body or to persons who have regular contact with it in connection with its purposes and that the data are not disclosed to a third party without the consent of the data subjects; or 
(e) the processing relates to data which are manifestly made public by the data subject or is necessary for the establishment, exercise or defence of legal claims.

3. Paragraph 1 shall not apply where processing of the data is required for the purposes of preventive medicine, medical diagnosis, the provision of care or treatment or the management of health-care services, and where those data are processed by a health professional subject under national law or rules established by national competent bodies to the obligation of professional secrecy or by another person also subject to an equivalent obligation of secrecy.

4. Subject to the provision of suitable safeguards, Member States may, for reasons of substantial public interest, lay down exemptions in addition to those laid down in paragraph 2 either by national law or by decision of the supervisory authority.

5. Processing of data relating to offences, criminal convictions or security measures may be carried out only under the control of official authority, or if suitable specific safeguards are provided under national law, subject to derogations which may be granted by the Member State under national provisions providing suitable specific safeguards. However, a complete register of criminal convictions may be kept only under the control of official authority.

Member States may provide that data relating to administrative sanctions or judgements in civil cases shall also be processed under the control of official authority.

6. Derogations from paragraph 1 provided for in paragraphs 4 and 5 shall be notified to the Commission.

7. Member States shall determine the conditions under which a national identification number or any other identifier of general application may be processed.

Вправа 2 (Група 1).

Mema: формувати граматичні навички. Очікуваний результат: студенти зможуть вживати модальні Аієслова, 
описуючи права та обов'язки сторін конфиікту. Інструменти системи Moоdle, за допомогою яких реалізується завдання: Тест. Tun вправи: рецептивно-репродуктивна, некомунікативна, письмова, одномовна, тренувацьна. Спосіб виконання: індивідуально. Контроль: з боку системи; завдання зараховується у разі правицьного виконання 60 \%; кількість спроб необмежена; форма оцінювання - краща оцінка. Інструкція: Choose the correct option to complete the gaps.

1. In accordance with this Directive, Member States ... protect the fundamental rights and freedoms of natural persons.
A shall
B may
$\mathrm{C}$ must

2. In the circumstances referred to in paragraph 1 (c), the controller ... designate a representative established in the territory of that Member State.
A shall
B may
C must

3. Member State shall provide that personal data ... be processed only if (a) the data subject has unambiguously given his consent.
A shall
B may
C must

4. Member State ... adopt legislative measures to restrict the scope of the obligations and rights provided for in Articles 6 (1), 10, 11 (1), 12 and 21.
A shall
B may
C must

5. Member State shall provide that the controller or his representative, if any, ... notify the supervisory authority referred to in Article 28 before carrying out any wholly or partly automatic processing operation or set of such operations intended to serve a single purpose or several related purposes.
A shall
B may
C must

6. Member State ... specify the information to be given in the notification.
A shall
B may
C must 


\section{Вправа 3 (Група 1).}

Мета: розвивати мовленнєві навичок на рівні речення. Очікуваний результат: студенти зможуть сформулювати основні положення Аирективи $Є С$ щодо захисту персональних Ааних особи, використовуючи необхідні мексичні одиниці та граматичні структури на рівні речення. Інструменти системи Moodle, за допомогоюяких реалізується вправа: Вікі. Тип вправи: рецептивно-репродуктивна, умовно-комунікативна, письмова, одномовна, тренувальна. Спосіб виконання: групове. Контроль: з боку системи перевіряється факт виконання завдання студентами; з боку викмадача перевіряється зміст повідомлення та наАається рефлексія у формі коментаря. Інструкиія: Study Directive 95/46/EC of the European Parliament and of the council of 24 October 1995 on the protection of individuals with regard to the processing of personal data and on the free movement of such data. Complete the chart with necessary information, using appropriate vocabulary and grammar.

\begin{tabular}{|l|l|}
\hline Article & Its main provisions \\
\hline Article 1 & \\
\hline Article 2 & \\
\hline Article 3 & \\
\hline Article 6 & \\
\hline Article 10 & \\
\hline Article 12 & \\
\hline Article 13 & \\
\hline Article 16 & \\
\hline Article 22 & \\
\hline Article 23 & \\
\hline Article 29 & \\
\hline
\end{tabular}


Сформовані піА час першого етапу необхіАні мовленнєві навички слугують необхіАним піАгрунтям Аля реалізації Аругого - анамітичного - етапу, який безпосередньо пов'язаний з роботою над текстами-зразками визначених жанрів юриАичного Аискурсу. Анахітичний етап націлений на визначення композиційних та жанрово-стилістичних особливостей різних жанрів юридичного Аискурсу: Аист-пораАа, Аист-попередження, Аист-віАповідь на попередження, меморандум, позовна заява.

Аля успішної реалізації аналітичного етапу розробляємо вправи Групи 2 на аналіз готових текстів визначених жанрів, їхньої композиції, мовних засобів Аця вираження тези, аргументів, висновків, а також засобів зв'язку композиційних частин. вправ та завдань. На цьому етапі використовуємо вправи рецептивно-аналітичного характеру, прикцаАи яких наводимо далі.

\section{Вправа 4 (Група 2).}

Meта: сформувати знання про основні характеристики миста-поради як жанру англійського аргументативного письма та проаналізувати характерні йому мовні засобами вираження. Очікуваний результат: студенти зможуть визначити могіку викмаАу композиційних частини миста-поради. Інструменти системи Moоdle, за допомогою яких реалізується вправа: Завдання. Tun вправи: рецептивно-аналітична, некомунікативна, письмова, одномовна, тренувацьна. Спосіб виконання: індивідуально. Контроль: з боку системи перевіряється факт виконання вправи студентами; з боку викладача перевіряється зміст повідомиення та надається рефлексія у формі коментаря. Інструкиія: Read the text. Decide on the following: a) what genre the text belongs to; b) what the legal issue, arguments and the conclusion are; c) what vocabulary and grammar are used for formulating the statement, arguments and the conclusion. 


\section{Dear Ms Smith}

Thank you very much for coming to see me yesterday when we discussed your dispute with Bristol CitiTravel. I am writing to summarise our discussion and to confirm your instruction.

You told me that you were a client of the local bus company Bristol CitiTravel and you booked a bus for your trips with the students of your school to London on the last Friday of every month. You didn't sign any contract with them and always asked for the bus by phone. On $10^{\text {th }}$ September the company secretary left you a message where she informed you that they couldn't give you a bus on Friday but on Saturday and asked to call them back and cancel the reservation if Saturday was no good. You used another bus company and forgot to call them back. The bus arrived on Saturday morning. Now CitiTravel wants the cost of $\$ 420$ for hiring the bus.

The legal issue here is whether or not you have a contractual relationship with Bristol CitiTravel. If yes, you are obliged to pay. If there is no contract, there is no obligation to pay.

The relevant precedent says that acceptance of an offer cannot be made by silence. It means that there was no contract between you and Bristol CitiTravel as one of the elements (acceptance) necessary to make a contract was missed. In my opinion, you did not form a contract with CitiTravel as you did not accept their offer to provide you with a bus on Saturday. That's why there is no obligation to pay $\$ 420$ to the bus company.

I will write to Bristol CitiTravel on your behalf and make our opinion on this matter clear to them. I will be in touch again shortly. Please do not hesitate to contact me if you have any questions.

Best wishes,

Linda Jefferson.

Вправа 5 (Група 2).

Мета: ознайомити із структурно-композиційними частинами миста-поради як жанру англійського аргументативного 
письма. Очікуваний результат: студенти зможуть визначити композиційні частини миста-поради. Інструменти системи Moodle, за допомогою яких реалізується вправа: Тест. Тип вправи: рецептивно-аналітична, некомунікативна, письмова, оАномовна, тренувальна. Спосіб виконання: індивідуацьно. Контроль: 3 боку системи; завАання зараховується у разі правильного виконання 60 \%; кількість спроб необмежена; форма оцінювання - краща оцінка. Інструкція: Read the text which follows a standard pattern for a letter of advice from a lawyer to a client. Match each paragraph (1-6) with its correct label (a-f):

Dear Mr Johnson,

(1) Thank you for coming to see me on 17 March when we discussed the situation regarding Mr. Brown's refusal to pay $\$ 1,000$ bonus under the agreement concluded between Mr. Brown and you. I am writing to summarise our discussion and confirm your instructions.

(2) You told me that Mr. Brown contacted your marketing company in Manchester to advertise the event "Save the Planet Day" that he decided to hold in St. James Park near his home in London on 15 February. Mr. Brown had a phone conversation with the manager of your company and the manager told him that the cost of promoting the event is $\$ 5,000$. Mr. Brown agreed and paid a deposit of $\$ 500$ by his credit card. After that, you told us that Mr. Brown phoned your manager a week before the event and he promised to pay o bonus of $\$ 1,000$ if you can persuade the ethical Food Company to come to the event. After persuading the Ethical Food Company to come to the event, Mr.Brown refused to pay the $\$ 1,000$ and said the original payment covers everything.

(3) The legal issue here is whether or not the manager of your company has concluded an extra-agreement with Mr. Brown and whether or not Mr. Brown is obliged to pay $\$ 1,000$ of bonus.

(4) In your situation the legal relationships are regulated by the legal provisions of Williams v. Roffey Ltd case (1991). According to 
the case of Williams v. Roffey Ltd case, since there was no duress or threat for the extra payment and the offer of extra money from Mr.Brown was made willingly and voluntarily, the extra benefit one of the parties receives (in our case the attendance of the Ethical Food company), should be paid for with extra consideration from Mr.Brown. Based on the abovementioned, we strongly believe that Mr.Browm is obliged to pay an extra \$1,000 to your company.

(5) I will write a letter to Mr.Brown on your behalf outlining the above and notifying him that he is obliged to pay the extra $\$ 1,000$ as a bonus. I will require confirmation from Mr. Brown to accept our interpretation and the relevant case law.

(6) I will be in touch again shortly. Please do not hesitate to contact me if you have any questions.

Kind regards,

Linda Jefferson.

a) Opening paragraph

b) Closing paragraph

c) The lawyer's proposed actions

d) The lawyer's advice

e) Summary of the facts

f) The legal issue(s)

Вправа 6 (Група 3).

Мета: визначити структурні частини аргументації (теза, аргумент, Аемонстрація) в межах аргументативного тексту. Очікуваний результат: студенти зможуть сформувати завершений аргументаційний акт. Інструменти системи Moodle, за допомогою яких реалізується вправа: Завдання. Тип вирави: репродуктивно-трансформаційна, некомунікативна, письмова, одномовна, тренувацьна. Спосіб виконання: індивіАуально. Контроль: з боку системи; завдання зараховується у разі правильного виконання 60 \%; кількість спроб необмежена; форма оцінювання - краща оцінка. Інструкція: Group the 
sentences into 4 completed passages paying your attention to the logically correct order. Define each sentence's function (whether it is a legal issue, an argument, or a conclusion):

The legal issue here is whether or not you have entered into contractual relations with the travel agency. 2) The legal issue here is whether or not Mr. Brown is contractually obliged to pay the extra money that he has already promised. 3) In such situations, the law is not completely clear as to the issues concerning the Company's legal status and your personal liability. 4) The law is very clear on problems such as yours. 5) Recent case law suggests that since there was no duress or threat for the extra payment and the offer of extra money from Mr. Brown was made willingly and voluntarily, the extra benefit one of the party receives, in our case the attendance of the Ethical Food Company, should be paid for with extra consideration from Mr. Brown. 5) I have reviewed the Articles of Incorporation of the Company and, in my opinion, pursuant to the laws of this jurisdiction, the company might be considered as no company at all. 6) In my opinion this argument represents the best possibility for you to avoid personal liability. 7) There is one final argument you could raise. 8) If there is a contract then you are obliged to pay $\$ 500$, if there wasn't a contract, you are not. 9) As Mrs. Brown did not do this, you may claim either a full refund or a replacement. 10) Under the Sale of Goods Act, if a reduction is offered due to imperfection of the product, the seller must inform the client on this defect at the time of purchase. 11) It is based on the concept that a party cannot argue that a would-be company was improperly formed when at all times it dealt with the undertaking as if it were validly formed.12) However, its success depends on the evidence presented, which means that a more detailed investigation of the facts is required. 13) There is a precedent that says acceptance of an offer cannot be made by silence, it must be actively communicated to the offeror. 14) Based on the abovementioned, I strongly believed 
you would be successful in case you choose to file a lawsuit against Mr. Brown. 15) Based on abovementioned, you probably do not have a contract with the travel agency and you are not obliged to pay $\$ 500$.

\section{Вправа 7 (Група 2).}

Мета: ознайомити 3 мовними засобами Аля вираження композиційних частин миста-поради як жанру ангмійського аргументативного письма. Очікуваний результат: студенти знатимуть мексичні одиниці, характерні Аля миста-поради як жанру англійського аргументативного письма. Інструменти системи Moodle, за допомогою яких реалізується вправа: Тест. Тип вирави: некомунікативна, письмова, одномовна, тренувальна. Спосіб виконання: індивідуально. Контроль: з боку системи; завдання зараховується у разі правицьного виконання 60 \%; кількість спроб необмежена; форма оцінювання - краща оцінка. Інструкція: Group the phrases into the following categories.

a) Opening paragraph:

b) Summary of the facts:

c) The legal issue(s):

d) The lawyer's advice:

e) The lawyer's proposed actions:

f) Closing paragraph:

The legal issue here is ...; Recent case law suggests that ...; Under these facts, a court would likely apply ...; The courts that have considered this question focus on ...; Applying these legal rules to ...; To sum up, based on the facts as I have recited them in this letter, I believe that ... The facts of our case raise the issue of ...; I will be in touch again shortly ...; Please do not hesitate to contact me if you have any questions ...; You told me that ... ; In relation to ...; One of the terms provide that ...; You will be liable for ...; Due to the circumstances under which ...; The law is very clear on problems such as yours ... . I am writing to summarise our discussion and to confirm 
your instruction ...; I am pleased to be helpful and to give you some professional advice on your matter ...; As far as I was informed by you that ...; I am pleased to confirm to you the advice that I gave to you...; I will write a letter to ... .

Третій - тренувахьний - етап спрямований на Аосягнення таких цікей: 1) формулювання правового питання (тези); 2) формулювання аргументів; 3) формулювання правового висновку; 4) подолання пінрозАім 2.2).

Аля успішної реалізації тренувального етапу розробцяємо групу тренувальних завдань репродуктивно-трансформаційного характеру (Група 3). Ця група вправ покмикана усунути могіко-композиційні труднощі аргументативного мовлення, Аопомогти студентам оволодіти змістом та формою аргументативного тексту та сприяє віАпрацюванню окремих операцій та Аій, що готують стуАентів Ао повноцінної мовценнєвої Аіяльності в межах англійського аргументативного письма. На Ааному етапі Аоцільно застосовувати метод Сократа, описаний нами у піАрозАілі 1.3 цього АосліАження.

Розглянемо Аекілька прикладів завдань тренувального етапу Аистанційного навчання англійського аргументативного письма майбутніх правознавців.

\section{Завдання 8 (Група 3).}

Мета: формувати уміння формулювати тезу у формі правового питання (legal issue) на рівні речення. Очікуваний результат: студенти зможуть сформулювати тезу (правове питання) в межах заданої ситуації. Інструменти системи Moodle, за допомогою яких реалізується вправа: Завдання. Тип вправи: репродуктивно-трансформаційна, умовно-комунікативна, письмова, одномовна, тренувальна. Спосіб виконання: індивідуально. Контроль: з боку системи перевіряється факт виконання завдання студентами; з боку викладача перевіря- 
ється зміст повідомлення та надається рефлексія у формі коментаря. Інструкція: Read the situations below and formulate a legal issue for each of them. Consult Directive 95/46/EC of the European Parliament and of the council of 24 October 1995 if necessary.

1) Mr. Smith was required to fulfill the questionnaire at his work where he needed, inter alia, to tell about his political opinions and religious belief. After his refusal, he wasn't given end-of-year bonus.

2) A famous actress has read a story in a popular magazine about her health, inter alia, details of her last illness and treatment. The magazine stated her first name and showed a picture of her leaving the hospital taken from her Instagram.

3) When being at doctor, Mrs. Jones was asked to provide a staff member with details of her health and sex life. After two weeks, Mrs. Jones' neighbour told her that she knew everything about her from her cousin who worked for Mrs. Jones' doctor.

4) The journalist revealed on his Facebook page the information about a politician's personal life, inter alia, his children's place of study, his wife's place of work and details of their last holiday. All the information was taken by the journalist from social networks such as Facebook, Twitter and Instagram.

\section{Завдання 9 (Група 3).}

Мета: сформулювати аргументи на підтверАження власної позиції. Очікуваний результат: студенти зможуть сформулювати аргументи в межах заданої ситуації. Інструменти системи Moodle, за допомогою яких реалізується вправа: Завдання. Tun вправи: репродуктивно-трансформаційна, умовнокомунікативна, письмова, одномовна, тренувальна. Спосіб виконання: індивіАуально. Контроль: з боку системи перевіряється факт виконання завдання студентами; з боку викладача 
перевіряється зміст повідомлення та надається рефлексія у формі коментаря. Інструкиія: Read the situations below and formulate strong arguments to support your opinion. Consult Directive 95/46/EC of the European Parliament and of the council of 24 October 1995 if necessary.

1) Mr. Smith was required to fulfill the questionnaire at his work where he needed, inter alia, to tell about his political opinions and religious belief. After his refusal, he wasn't given end-of-year bonus.

2) A famous actress has read a story in a popular magazine about her health, inter alia, details of her last illness and treatment. The magazine stated her first name and showed a picture of her leaving the hospital taken from her Instagram.

3) When being at doctor, Mrs. Jones was asked to provide a staff member with details of her health and sex life. After two weeks, Mrs. Jones' neighbour told her that she knew everything about her from her cousin who worked for Mrs. Jones' doctor.

4) The journalist revealed on his Facebook page the information about a politician's personal life, inter alia, his children's place of study, his wife's place of work and details of their last holiday. All the information was taken by the journalist from social networks such as Facebook, Twitter and Instagram.

\section{Завдання 10 (Група 3).}

Мета: формування аргументативних умінь шияхом інтегрування умінь формулювання тези, аргументів та висновку. Очікуваний результат: студенти зможуть сформулювати тезу, навести вагомі аргументи та сформулювати висновки, що базуватимуться на чинному законодавстві. Інструменти системи Moodle, за допомогою яких реалізується вирава: Форум. Тип 
завдання: продуктивне, комунікативне, письмове, одномовне, тренувальне. Спосіб виконання: індивідуально. Контроль: з боку системи перевіряється факт виконання завдання студентами; з боку викладача перевіряється зміст повідомлення та надається рефлексія у формі коментаря. Інструкція: Comment on the following situations stating a legal issue, providing arguments and making a relevant conclusion.

1) At the job interview Mrs. White was required to fulfill the questionnaire where she needed, inter alia, to tell about her trade-union membership. After her refusal, she wasn't offered a position.

2) At a popular talk show devoted to celebrities' lifestyle, they talked about details of a famous actor's last illness and treatment. The information was taken from social networks and actors' friends who had come to the studio.

3) When being at the doctor, Mrs. Jones was asked to provide a staff member with details of her health and sex life. After two weeks, Mrs. Jones' neighbour told her that she knew everything about her from her cousin who worked for Mrs. Jones' doctor.

4) The journalist revealed on his Facebook page the information about a politician's personal life, inter alia, his children's place of study, his wife's place of work and details of their last holiday. All the information was taken by the journalist from social networks such as Facebook, Twitter and Instagram.

Сформованість мовленнєвих навичок та аргументаційних умінь, а також знань композиційних та жанрово-стилістичних особливостей визначених жанрів юридичного Аискурсу переАбачають їх подальше інтегрування в уміння англійського аргументативного письма, що реалізується на третьому - текстовопродукувальному - етапі. Суть цього етапу полягає 
в написанні власних аргументаційних текстів у визначених жанрах юриАичного Аискурсу. ЦіАями текстово-продуктивного етапу визначаємо 1) удосконалення аргументаційних умінь та 2) формування текстово-продукувальних умінь. Аосягнення зазначених цілей віАбувається шияхом виконання завдань Групи 4, які спрямовані на вирішення конкретного кейсу.

Розглянемо приклади завдань текстово-продукувального етапу Аистанційного навчання англійського аргументативного письма майбутніх правознавців.

ЗавАання 11 (Група 4).

Mета: удосконалювати аргументативні уміння у написанні миста-поради в межах визначеної ситуації спілкування з її попереАнім вивченням та обговоренням. Очікуваний результат: студенти зможуть написати мист-пораду як жанр англійського аргументативного письма, застосовуючи вивчені цексичні одиниці та граматичні конструкції, на основі текстових опор. Інструменти системи Moоdle, за допомогою яких реалізується завдання: а) Чат; b) Форум; с) Вікі; d) Завдання; Файл; е) Семінар. Спосіб виконання: індивідуально, в групі, в парах. Контроль: з боку викладача; самоконтроль; взаємоконтроль. Інструкція: Study the situation.

Mr. Smith was asked to fulfill the questionnaire at his work where he needed, inter alia, to tell about his political opinions and religious belief. After his refusal, he wasn't given end-of-year bonus. The manager explained to Mr. Smith that their company encouraged honesty and trust within the staff. Though the manager was satisfied with Mr. Smith's work, he could give him neither end-of-year bonus nor promotion.

a) Put the questions to Mr. Smith to find out more details on the matter.

b) Discuss the legal issue(s) of the matter and propose ways to resolve it. 
c) Complete the chart.

\begin{tabular}{llll}
\hline Legal issue(s) & Regulations & $\begin{array}{l}\text { Proposed } \\
\text { actions }\end{array}$ & $\begin{array}{l}\text { Legal } \\
\text { consequences }\end{array}$ \\
\hline
\end{tabular}

e) You are Mr. Smith's lawyer. Write a letter of advice in approximately 200-250 words.

f) Analyze your groupmate's letter of advice. Comment on the following aspects: legal content; reasoning; letter structure; language.

\section{ЗавАання 12 (Група 4).}

Мета: удосконалювати текстово-продукувацьні уміння англійського аргументативного письма без опори на попереАнє обговорення ситуації спілкування в межах якої вона реалізується. Очікуваний результат: студенти зможуть індивіАу-

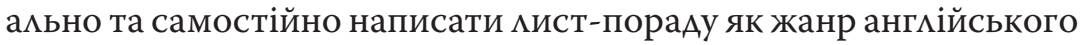
аргументативного письма. Інструменти системи Moodle, за допомогою яких реалізується завдання: Завдання; Файл. Тип вправи: комунікативна, письмова, одномовна, контрольна. Спосіб виконання: індивідуально. Контроль: з боку викмадача. Час виконання: 60 хвилин. Кількість спроб: 1. Інструкція: Yоu are Mary Brown's lawyer. Write a letter of advice in approximately 200-250 words.

Mary Brown was a patient of a local hospital. Last week she watched a TV show devoted to Health Care where the journalists described her case mentioning her first name and demonstrating her photo. She was very much shocked as she didn't provide any consent on processing her personal data. Now she wants to bring a claim against a TV channel for violation the UK Regulation on Personal Data Protection. 
Аля кращої зручності сприйняття піАсистему вправ та завАань Аля Аистанційного навчання англійського аргументативного письма студентів-юристів подаємо у формі таблиці:

Таблиця 2.3.1 - ПіАсистема вправ та завдань Аля Аистанційного навчання англійського аргументативного письма студентів-юристів

\begin{tabular}{|c|c|c|}
\hline 造 & $\begin{array}{l}\text { Група 1: } \\
\text { мексичні } \\
\text { та граматичні } \\
\text { вправи }\end{array}$ & $\begin{array}{l}\text { некомунікативні та умовно-кому- } \\
\text { нікативні вправи на формування } \\
\text { мексичних навичок; } \\
>\text { некомунікативні та умовно-комуніка- } \\
\text { тивні вправи на формування грама- } \\
\text { тичних навичок. }\end{array}$ \\
\hline 突 & $\begin{array}{l}\text { Група 2: } \\
\text { рецептивно- } \\
\text { анамітичні } \\
\text { вправи }\end{array}$ & $\begin{array}{l}\text { вправи на визначення структур- } \\
\text { но-композиційних частин визначених } \\
\text { жанрів англійського аргументативного } \\
\text { письма; } \\
\text { вправи на визначення могіки викмаду } \\
\text { композиції визначених жанрів англій- } \\
\text { ського аргументативного письма; } \\
\text { вправи на визначення мовних засобів } \\
\text { Аля вираження тези, аргументів, } \\
\text { висновків, а також засобів зв'язку } \\
\text { композиційних частин. }\end{array}$ \\
\hline 晃 & $\begin{array}{l}\text { Група 3: } \\
\text { репродуктивно- } \\
\text { трансформаційні } \\
\text { завдання }\end{array}$ & $\begin{array}{l}>\text { завдання на формулювання правового } \\
\text { питання (тези); } \\
\text { завАання на формулювання аргументів, } \\
\text { що підтримують власну позицію; } \\
>\text { завдання на формування аргумента- } \\
\text { тивних умінь. }\end{array}$ \\
\hline 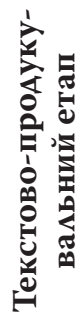 & $\begin{array}{l}\text { Група 4: } \\
\text { виконавчі завдання } \\
\text { на продукування } \\
\text { визначених жанрів } \\
\text { англійського } \\
\text { аргументативного } \\
\text { письма }\end{array}$ & $\begin{array}{l}>\text { завдання на удосконалення аргумента- } \\
\text { тивних умінь; } \\
\text { завдання на продукування та пере- } \\
\text { вірку текстово-продукувацьних } \\
\text { умінь англійського аргументативного } \\
\text { письма. }\end{array}$ \\
\hline
\end{tabular}


Отже, Аистанційне навчання англійського аргументативного письма майбутніх правознавців ми пропонуємо зАійснювати у чотири етапи (піАготовчий, аналітичний, тренувальний та текстово-продукувацьний) за Аопомогою визначеної підсистеми вправ та завдань. Успішність реалізації кожного етапу залежить віА Аосягнення поставлених цілей. Так, піАготовчий етап націлений на формування мовленнєвих навичок у продукуванні англійського аргументативного письма в межах віАповідного жанру та на подолання мовних та преАметних труАнощів; на аналітичному етапі ставимо за мету проаналізувати готові тексти Аля визначення композиційних та жанрово-стиАістичних особливостей різних жанрів юридичного Аискурсу: миста-поради, миста-попередження, миста-відповіді на попереАження, меморандуму, позовної заяви; тренувальний етап спрямований на Аосягнення таких цілей як формулювання тези, аргументів та висновку, а також подолання цогічних труднощів; цілями текстово-продукувацьного етапу визначаємо удосконаАення аргументаційних умінь та формування текстово-продукувальних умінь.

\section{4 Модемь Аистанційного навчання ангАійського аргументативного письма стуАентів-правників}

Ефективна реацізація авторської методики Аистанційного навчання англійського аргументативного письма можмива шляхом створення Аієвої моделі навчання, яка зАатна врахувати всі істотні властивості та параметри, важмиві Аля Аосягнення запланованого результату - формування у студентів-юристів умінь англійського аргументативного письма. Погоджуємося 3 Аумкою американського філософа 
М. Вартофського, що моделі - це цілеспрямовано створювані конструкції, артифакти, проміжні сутності, за допомогою яких ми пізнаємо існування реацьних об'єктів ${ }^{308}$. Тож, модель навчання ангАійського аргументативного письма $€$ невіА'ємним скиадником процесу підготовки i проведення навчальної дія Аьності.

\section{У Аінгводидактичному енциклопедичному словнику} за редакцією А.М. Щукіна модель організації навчального процесу визначається як індивіАуацьна інтерпретація викцаАачем методу навчання віАповіАно Ао постав ених цілей та умов роботи, реалізація якого зАійснюється за Аопомогою обраної викладачем технології навчання ${ }^{309}$. Український вчений В.В. Ягупов описує модель навчального процесу як «еталонне уяв ення про навчання учнів, його конструювання в умовах конкретних освітньо-виховних закцадів, що визначає цілі, основи організації та проведення навчацьного процесу» ${ }^{310}$. На Аумку наших американських колег, АиАактична модель навчання за своїми властивостями зАатна Аопомогти викладачам краще усвідомити основні фокуси конкретної навчальної Аіяльності, ефективніше залучати більшу кількість студентів, розширювати асортимент прийомів і техно-

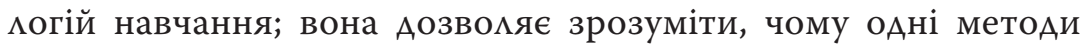
працюють, а інші - ні, а також дає можиивість змінювати вже існуючі методики, щоб нові, удосконалені, краще віАповіАали потребам сучасних студентів ${ }^{311}$.

${ }^{308}$ Вартофский М. Модели. Репрезентация и научное понимание: пер. с англ. Москва: «Прогресс», 1988. С. 61.

${ }^{309}$ Щукин А. Н. Аингводидактический энцикмопедический словарь. Москва: Астрель; АТС; Хранитель, 2007. С. 159.

${ }^{310}$ Ягупов В. В. Педагогіка - модель навчання (модель навчального процесу). URL: http://eduknigi.com/ped_view.php?id=131.

${ }^{311}$ Wilson L. O. The Second Principle. URL: http://thesecondprinciple.com/teaching-essentials/models-of-teaching/ 
Таким чином, мише за умови побудови АиАактичної моделі Аистанційного навчання англійського аргументативного письма, теоретичне обгрунтування Аосліджуваної нами проблеми набуває практичної цінності і зАатне забезпечити ефективну реалізацію поставлених цілей і завдань. Подімяючи позицію В.В. Ягупова, вважаємо що Аидактична модель має віАповіАати наступним вимогам: вона має бути, з оАного боку, об'єктивною і відображати суще, а 3 іншого, суб'єктивною, такою, що здатна відображати об'єкт з урахуванням тезаурусу реципієнта; модель також повинна відображати бажане і передбачати Аіалог зі студентом, пристосовуватись Ао індивіАуальних особливостей АюАини, передусім до рівня різновидів ії АосвіАу та переАбачати проективно-технологічну нормотворчість Аіяльності реципієнта ${ }^{312}$.

ПіА час розробки моделі дистанційного навчання англійського аргументативного письма ми також враховуваци характеристики Аидактичної моделі, визначені $\Lambda$.В. Курило ${ }^{313}$ :

1) послідовність (модель відображає етапність та піАпорядкованість та могіку організації навчального процесу);

2) взаємопов'язаність (модель Аемонструє системну роботу всіх своїх скцадових компонентів);

3) цілеспрямованість (модель націлена на реалізацію цілей, Ае кожний етап супроводжується описом проміжного очікуваного результату).

Розглянемо скмадові Аидактичної моделі, які визначають іiі структуру і зміст. Аналіз останніх Аисертаційних

312 Ягупов В. В. Педагогіка - модель навчання (модель навчального процесу). URL: http://eduknigi.com/ped_view.php?id=131.

${ }^{313}$ Куримо $\Lambda$. В. Навчання майбутніх викмадачів англійської мови професійно орієнтованого наукового писемного мовлення: Аис. ... канА. пеА. наук: 13.00.02. Київ, 2014. C. 177-178. 
Заярна I.C. Методика дистанційного навчання

англійського аргументативного письма майбутніх правознавців

АосліАжень ${ }^{314}, 315,316,317,318,319,320,321$ Аозволяє виокремити такі компоненти Аидактичної моделі як цімі навчання, обєєк навчання, суб'єкти навчання, навчамьна Аисципміна, в межах якої побудовано модець, норми часу, зміст навчання, методи та способи навчання, форми організації навчання, засоби навчання, форми контролю навчальної Аіяльності студентів під час аудиторної і позааудиторної роботи, очікуваний результат. Крім того, враховуючи особливості навчацьного середовища, опосереАкованого комп'ютером, та важиивість створення соціальної спільноти і психомогічної комфортності, ми також вкцючими в модель Аистанційного навчання англійського аргументативного письма такий важливий компонент як інтеракція, тобто взаємодія студента із викмадачем, іншими студентами, змістом, наданим у різних форматах та інтерфейсом комп'ютера.

${ }^{314}$ Бачинська I. А. Формування англомовної мінгвосоціокумьтурної компетенції учнів старшої школи: Аис. ... канА. пеА. наук: 13.00.02. Херсон, 2015. 217 с.

${ }^{315}$ Крисак $\Lambda$. В. Методика навчання майбутніх мікарів загальної практики англомовного професійно орієнтованого Аіалогічного мовмення: Аис. ... канА. пеА. наук: 13.00.02. Київ, 2016. 285 с.

${ }^{316}$ Аитвиненко I. Ю. Методика навчання студентів технічних спеціальностей англомовного читання на засадах інтеграції: Аис. ... канА. пеА. наук: 13.00.02. Херсон, 2015. 255 с.

${ }^{317}$ Михайленко О. А. Методика навчання майбутніх філологів стратегій письмового перекцаду офіційно-ділових текстів з української мови на англійську: Аис. ... канА. пеА. наук: 13.00.02. Київ, 2015. 258 с.

${ }^{318}$ Патієвич О. В. Методика навчання стилістичної унормованості наукового писемного англійського мовлення майбутніх фізиків в умовах магістратури: Аис. ... канд. пеА. наук: 13.00.02; М-во освіти і науки України, Київ. нац. ун-т імені Тараса Шевченка. Київ, 2015. 276 с.

319 Трикашна Ю. І. Формування англомовної соціокультурної компетентності у майбутніх філологів з використанням автентичного художнього фільму: Аис. ... канА. пеА. наук: 13.00.02. Київ, 2017. 394 с.

${ }^{320}$ Цепкало О. В. Методика навчання комунікативних стратегій професійно спрямованого англомовного писемного спіккування майбутніх фахівців 3 машинобудування: Аис. ... канА. пеА. наук: 13.00.02; НТУ КПІ імені І. Сікорського. Київ, 2017. 244 с.

${ }^{321}$ Al-Ghanimi Q., Jameel Rashid. Teaching reading English academic texts to philology students: Ph. D. thesis: 13.00.02. Kyiv, 2017. 323 p. 
Метою навчання англійського аргументативного письма майбутніх правознавців визначаємо формування навичок та умінь вільно та самостійно (одержавши всю необхідну інформацію і не користуючись Аодатковими матеріалами) створювати у віАповіАності до встановлених критеріїв та жанрових зразків юриАичні тексти аргументативного писемного мовцення. Аетально цілі та завдання навчання ангАійського аргументативного письма також розглянуті нами у піАрозАілі 2.1 .

Очікуваний резумьтат. По завершенню Аистанційного курсу, присвяченого навчанню англійського аргументативного письма, студенти спеціальності 081 «Право» будуть зАатними самостійно, не користуючись Аопоміжними матеріалами, продукувати юридичні письмові тексти, використовуючи аргументативні тактики та віАповіАний їм мовним матеріа^, у таких жанрах юриАичного Аискурсу як мист-порада, меморандум, позовна

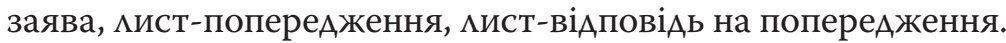

Суб'єктами навчання визначаємо студентів I курсу ОР «Бакалавр» спеціальності 081 «Право», об'єктом навчання $\boldsymbol{\epsilon}$ англійське аргументативне юридичне письмо.

Зміст навчання ангАійського аргументативного письма формують віАповідні знання, навички та уміння, Аетально описані у п. 2.1. цього монографічного Аослідження.

Принципи навчання. Аидактичні (посильності, свіАомості, активності, наочності), психологічні (принципи мотивації, поетапності формування мовленнєвих умінь та навичок, врахування індивідуально-психологічних особливостей особистості студента, врахування адаптаційних процесів) та методичні (комунікативності, автентичності, професійної спрямованості навчання, ситуативно-тематичної організації навчання) принципи.

Методи навчання. Метод кейсів та метод Сократа.

Модель реалізується в межах навчальної Аисципміни «Іноземна мова (англійська)». 
Засоби навчання: авторський Аистанційний курс English Legal Reasoning Writing to Law Students на платформі віртуального навчання Moodle. ПіА час розробки курсу використовувалися автентичні матеріаци юридичного спрямування, зокрема, такі як Аирективи та Рекомендації Європейського Союзу, тексти Аоговорів, статути компаній та товариств, фахові журнальні та газетні статті, аудіо мекції провіАних професорів та юристів-практиків. Нами також був укмадений юриАичний глосарій Ао віАповіАних тем, який містить не мише визначення термінів на англійській мові і їх перекцаА (або еквівалент) на українській мові, але й синхронізацію з матеріамами курсу.

Ао технічних засобів, які застосовуються піА час Аистанційного навчання англійського аргументативного письма, належать наступні інструменти віртуальної системи Moodle: комунікативні (Форум, Чат, Обмін повідомленнями), навчальні (Урок, Завдання, Тести, Анкети, Опитування, Вікі, ГАосарій, Семінар), адміністративні (Оцінки, Групи, Звіти, Файли).

Форма організації: позааудиторна робота.

Інтерактивність. Визначаємо такі види взаємодії в межах моделі Аистанційного навчання англійського аргументативного письма: студент-студент (СС), студент-викиадач (СВ), студент-контент (СК), студент-інтерфейс (CI).

Норми часу. Визначення обсягу часу, необхіАного Аһя реалізації запропонованої моделі Аистанційного навчання ангАійського аргументативного письма, обумовлене кількістю годин, виАілених Аля вивчення Аисципліни «Іноземна мова (англійська)» на юридичному факультеті Київського національного університету імені Тараса Шевченка, на базі якого проводилася експериментальна перевірка моделі. Викмадання англійської мови Аля студентів ОР «Бакалавр» спеціальності 081 «Право» триває упродовж 2-х семестрів. 
Кількість креАитів ЕСТS - 7. Загацьний обсяг годин - 429. Всього аудиторних гоАин - 208 (усі практичні). Самостійна робота - 212 гоА. У II семестрі розподік аудиторних і позааудиторних (самостійна робота) годин такий: 104 гоАини аудиторної роботи (3,5 години на тиждень) / 106 годин позааудиторної роботи.

Пропонуємо на проходження Аистанційного курсу English Legal Reasoning Writing to Law Students видікити 60 позаауАиторних гоАИн. Ми виАіАИли 56,6\% позаауАиторних гоАИн II семестру на навчання ангАійського аргументативного письма, що обумовлюється наступними причинами: 1) піА час навчання англійського аргументативного письма студенти також розвивають уміння читання та аудіювання; 2) Аоцільність більше витрачати позааудиторного часу на написання текстів, в той час як аудиторіні години більше присвячувати говорінню.

Форми контролю. ПіА час Аистанційного навчання англійського аргументативного письма ми будемо застосовувати формуюче оцінювання та підсумкове оцінювання. Формуюче оцінювання (поточний контроль) націлене на реалізацію навчальної та розвиваючої функції навчання, а також функції зворотного зв'язку. В нашій моделі ми будемо застосовувати категорії «Скмав/Не скмав», бали та коментарі. Віртуальне середовище Аає можливість студенту на необмежену кількість спроб Аля проходження завдання, що $є$ корисним піА час формуючого оцінювання. ПіАсумкова оцінка, натомість, виставцяється в кінці кожного блоку (моАулю)

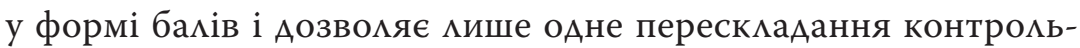
ного завАання.

ПіА час Аистанційного навчання англійського аргументативного письма ми також будемо використовувати взаємоконтроль, коли студенти перевіряють і оцінюють роботи оАин 
оАного, та самоконтроль, коли стуАенти анацізують та УАосконалюють власне виконання навчального завАання 322 .

Аистанційний курс English Legal Reasoning Writing to Law Students скмадається 3 п'яти модулів, присвячених віАповіАно навчанню написанню миста-поради, миста-попередження, миста-віАповіАі на попереАження, меморандуму та позовної заяви. Кожен модуль реалізується в чотири етапи. Строк проходження кожного модумя - 1,5 тижні з орієнтовним навантаженням 1,5-2 години щоАня.

I етап - піАготовчий - триває 2 академічні години. I етап спрямований на формування мовленнєвих навичок у продукуванні англійського аргументативного письма в межах віАповіАного жанру, а також на подолання мовних та преАметних трУАнощів.

ПіАготовчий етап передбачає виконання 4-5 вправ різних видів та типів. Вправи на цьому етапі оцінюються за принципом скиав/не скиав, Ае скиав - це 60\% вірного виконання завАання. Кількість спроб виконання не обмежується, але перейти Ао наступного етапу можна мише за умови успішного (не менше $60 \%)$ виконання всіх вправ I етапу.

II етап - аналітичний - триває 3 академічні години і ставить за мету проанацізувати готові тексти А^я визначення композиційних та жанрово-стилістичних особливостей різних

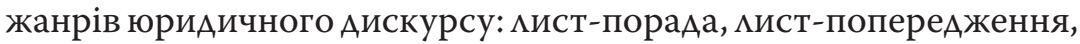
мист-віАповіАь на попереАження, меморандум, позовна заява

Аналітичний етап передбачає виконання 5-6 вправ різних видів та типів. Аналогічно до попереАнього етапу, вправи на цьому етапі оцінюємо за принципом склав/не склав, Ае скмав - це $60 \%$ вірного виконання завдання. Кількість спроб

${ }^{322}$ Zaiarna I.S. The Model for E-Teaching English Reasoning Writing to Law Students Based on LMS MOODLE. Information Technologies and Learning Tools. Vol. 76. No. 2. 2020. P. 152-162. URL: https://journal.iitta.gov.ua/index.php/itlt/article/view/3332 
виконання не обмежується, але перейти Ао наступного етапу можна мише за умови успішного (не менше 60\%) виконання всіх вправ II етапу.

III етап - тренувальний - триває 3 академічні години і спрямований на досягнення таких цімей як формулювання тези, аргументів та висновку, а також подолання Аогічних труднощів.

Тренувальний етап передбачає виконання 6-8 вправ та завдань різних виАів та типів. Аналогічно до попереАнього етапу, вправи та завдання на цьому етапі оцінюємо за принципом скмав/не скмав, Ае скмав - це 60\% вірного виконання завдання. Кількість спроб виконання не обмежується, але перейти до наступного етапу можна кише за умови успішного (не менше 60\%) виконання всіх вправ III етапу. ААя Аосягнення цілей активно застосовуємо метод Сократа. На цьому етапі ми також широко застосовуємо такі інструменти системи Moodle як Форум і Чат, які дають можливість забезпечити інтерактив і письмові дебати між усіма суб'єктами навчання.

IV етап - текстово-продукувальний - триває 4 академічні години і спрямований на удосконалення аргументативних та формування текстово-продуктивних умінь шляхом написання в асних аргументаційних текстів у визначених жанрах юридичного Аискурсу. Аля Аосягнення цілей активно застосовуємо метод кейсів та метод Сократа. Модумь вважається таким, що успішно завершений, за умови успішного (60\% і більше) виконання підсумкового контрольного завдання, яке оцінюється викмадачем за 5 критеріями.

Таким чином, модель Аистанційного навчання англійського аргументативного письма скмадається із п'яти модулів (віАповіАно Ао кількості визначених жанрів юридичного Аискурсу). Кожен модуль націлений на оволодіння окремим жанром англійського аргументативного письма і реалізується в чотири етапи етапи (Модумь 1 присвячений навчання миста поради; 
Модуль 2 - кист-попереАження; Модуль 3 - кист-віАповідь на попередження; Модуль 4 - меморандум; Модуль 5 - позовна заява). Модель враховує зміст навчання англійського аргументативного письма, сучасні піАходи до викмадання і оцінювання, особливості освітнього середовища, опосередкованого комп'ютером. Перевагою моделі $€$ також ії гнучкість: ми можемо змінювати як жанри англійського аргументативного письма, так i їх кількість. Подамо графічне зображення моделі Аистанційного навчання ангмійського аргументативного письма (ААП) студентів-правників (рис. 2.4.1).

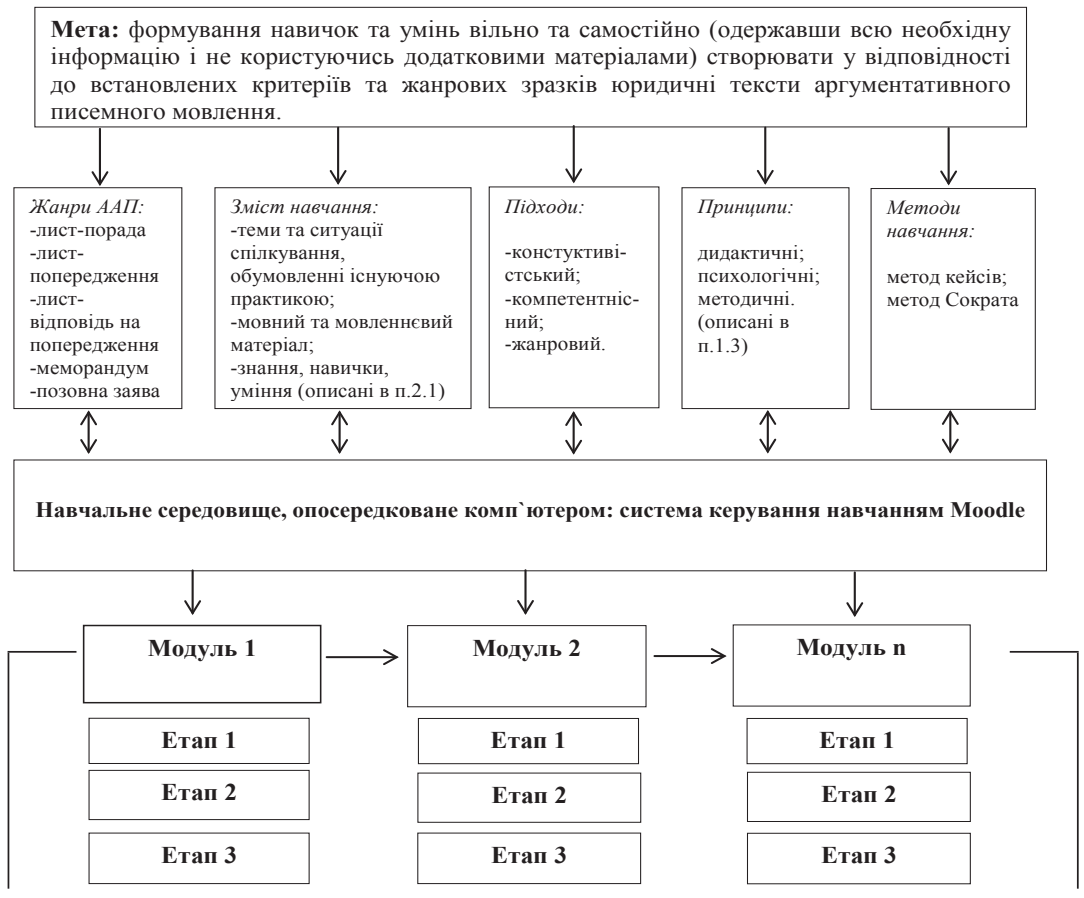

Рисунок 2.4.1 - Модель Аистанційного навчання англійського аргументованого письма студентів-правників (початок) 
Розділ 2. Методика дистанційного формування умінь англійського аргументативного письма майбутніх правознавців

\begin{tabular}{|c|c|c|c|c|c|}
\hline \multicolumn{2}{|l|}{ Етап 4} & \multicolumn{2}{|c|}{ Етап 4} & \multicolumn{2}{|c|}{ Етап 4} \\
\hline \multicolumn{2}{|l|}{$\downarrow$} & \multicolumn{2}{|l|}{$\downarrow$} & \multicolumn{2}{|c|}{$\downarrow$} \\
\hline \multicolumn{6}{|c|}{$\begin{array}{l}\text { Очікуваний результат: студенти зможуть самостійно, не користуючись } \\
\text { допоміжними матеріалами, продукувати юридичні письмові тексти, } \\
\text { використовуючи аргументативні тактики та відповідний їм мовним матеріал, у } \\
\text { таких жанрах юридичного дискурсу як лист-порада, меморандум, позовна заява, } \\
\text { лист-попередження, лист-відповідь на попередження. }\end{array}$} \\
\hline \multicolumn{6}{|c|}{ Структура навчального модуля } \\
\hline Етапи & $\begin{array}{l}\text { К-ть } \\
\text { акад. } \\
\text { год. }\end{array}$ & $\begin{array}{c}\text { Об’єкт } \\
\text { навчання }\end{array}$ & $\begin{array}{l}\text { Технічні засоби } \\
\text { (інструменти } \\
\text { системи Mоodle) }\end{array}$ & $\begin{array}{l}\text { Інтер- } \\
\text { акція }\end{array}$ & $\begin{array}{c}\text { Режим } \\
\text { контролю }\end{array}$ \\
\hline \multirow[t]{2}{*}{$\begin{array}{l}1 \text { етап } \\
\text { (підготовчий) }\end{array}$} & 2 & $\begin{array}{l}\text { Мовленнєві } \\
\text { навички }\end{array}$ & $\begin{array}{l}\text { Урок, Глосарій, } \\
\text { Завдання, } \\
\text { Тести, } \\
\text { Чат, }\end{array}$ & $\begin{array}{l}\mathrm{CK} \\
\mathrm{CI} \\
\mathrm{CB} \\
\mathrm{CC}\end{array}$ & $\begin{array}{l}\text { Формуюче } \\
\text { оцінювання }\end{array}$ \\
\hline & & & $\begin{array}{l}\text { Форум, } \\
\text { Обмін повідо- } \\
\text { мленнями }\end{array}$ & & \\
\hline $\begin{array}{l}\text { Очікуваний } \\
\text { результат }\end{array}$ & \multicolumn{5}{|c|}{$\begin{array}{l}\text { Студенти знатимуть лексичні одиниці та граматичні структури, } \\
\text { характерні для ААП юриста у визначеному жанрі та зможуть засто- } \\
\text { совувати отриманні знання на письмі. }\end{array}$} \\
\hline $\begin{array}{l}2 \text { етап } \\
\text { (аналітичний) }\end{array}$ & 3 & $\begin{array}{l}\text { Структурно- } \\
\text { копозиційні } \\
\text { знання; } \\
\text { аналітичні } \\
\text { уміння та мовні } \\
\text { навички }\end{array}$ & $\begin{array}{l}\text { Урок, } \\
\text { Завдання, } \\
\text { Тести, } \\
\text { Чати, } \\
\text { Форум, } \\
\text { Вікі }\end{array}$ & $\begin{array}{l}\mathrm{CC} \\
\mathrm{CB} \\
\mathrm{CI} \\
\mathrm{CK}\end{array}$ & $\begin{array}{l}\text { Формуюче } \\
\text { оцінювання }\end{array}$ \\
\hline $\begin{array}{l}\text { Очікуваний } \\
\text { результат }\end{array}$ & \multicolumn{5}{|c|}{$\begin{array}{l}\text { Студенти знатимуть структурно-композиційні частини визначених } \\
\text { жанрів ААП, а також характерні ним лексичні одиниці та грама- } \\
\text { тичні структури. }\end{array}$} \\
\hline $\begin{array}{l}3 \text { етап } \\
\text { (аргументаційно- } \\
\text { тренувальний) }\end{array}$ & 3 & $\begin{array}{l}\text { Агрументаційні } \\
\text { уміння }\end{array}$ & $\begin{array}{l}\text { Урок, } \\
\text { Завдання, } \\
\text { Тести, } \\
\text { Чати, } \\
\text { Форум } \\
\end{array}$ & $\begin{array}{l}\mathrm{CC} \\
\mathrm{CB} \\
\mathrm{CK} \\
\mathrm{CI}\end{array}$ & $\begin{array}{l}\text { Формуюче } \\
\text { оцінювання }\end{array}$ \\
\hline $\begin{array}{l}\text { Очікуваний } \\
\text { результат }\end{array}$ & \multicolumn{5}{|c|}{$\begin{array}{l}\text { Студенти знатимуть логіко-лінгвітичну структуру аргументації; } \\
\text { вмітимуть сформулювати тезу, аргументи та висновки у межах } \\
\text { заданої ситуації спілкування. }\end{array}$} \\
\hline $\begin{array}{l}4 \text { етап (текстово- } \\
\text { продукувальний) }\end{array}$ & 4 & $\begin{array}{l}\text { Текстово- } \\
\text { продуктивні } \\
\text { уміння }\end{array}$ & $\begin{array}{l}\text { Завдання, } \\
\text { Тести, } \\
\text { Чат, } \\
\text { Форум, } \\
\text { Семінар, } \\
\text { Вікі }\end{array}$ & $\begin{array}{l}\text { CC } \\
\text { CB } \\
\text { CK } \\
\text { CI }\end{array}$ & $\begin{array}{l}\text { Формуюче } \\
\text { оцінювання, } \\
\text { Підсумкова } \\
\text { оцінка }\end{array}$ \\
\hline $\begin{array}{l}\text { Очікуваний } \\
\text { результат }\end{array}$ & \multicolumn{5}{|c|}{$\begin{array}{l}\text { Студенти вмітимуть самостійно написати відповідно до встанов- } \\
\text { лених критеріїв і зразків один із жанрів ААП юриста. }\end{array}$} \\
\hline
\end{tabular}

Рисунок 2.4.1 - Модель Аистанційного навчання ангиійського аргументованого письма студентів-правників (закінчення) 
Отже, розроблена модель Аистанційного навчання англійського аргументативного письма реалізується в межах навчальної Аисципліни «Іноземна мова (англійська)» піА час 1-го року навчання Аця студентів ОР «Бакалавр» спеціальності 081 «Право» упродовж 6 тижнів (60 позааудиторних годин). Модель Аистанційного навчання англійського аргументативного письма має модульний характер. Кожен модуль присвячений навчанню написанню тексту певного жанру англійського аргументативного письма, охопмює 12 позааудиторних академічних годин та реалізується у чотири етапи. Так, піАготовчий етап потребує 2 години, аналітичний етап - 3 години, тренувальний -3 години, текстово-продукувальний -4 академічні гоАИНИ.

Перевірка ефективності моделі відбувалась у ході провеАення навчального експерименту, опис якого преАставцено у розАілі III. 


\section{PO3АI $\wedge 3$ \\ Експериментальна перевірка методики Аистанційного навчання англійського аргументативного письма майбутніх правознавців}

У третьому розділі описано процес планування, підготовки та проведення експерименту; сформульовано критерії та норми оцінки результатів навчання, спрямованого на формування умінь англійського аргументативного письма; експериментально перевірено ефективність авторської методики та розроблено методичні рекомендації Ао Аистанційного навчання ангАійського аргументативного письма майбутніх правознавців на базі LMS MOODLE.

\section{1 Пианування та підготовка експерименту. Розроблення критеріїв та норм оцінювання ангмійського аргументативного письма}

Ефективність запропонованої методики Аистанційного навчання ангАійського аргументативного письма перевірялась у ході методичного експерименту, який проводився у кілька етапів у період з березня по травень 2018 рік на базі кафедри іноземних мов юридичного факультету Київського національного університету імені Тараса Шевченка.

Теоретичну основу методології експериментального Аослідження становици головні положення теорії методичного 
експерименту, викладені у працях таких провіАних вітчизняних і зарубіжних науковців як С. Архангельський, В. Беспалько, П. Гурвич, М. Аяховицький,А. Мартін, С. Сисоєва, Є. Штульман. У ході піАготовки, організації та проведення експерименту нами також були враховані результати останніх Аисертаційних АосліАжень 3 методики викмадання іноземних мов ${ }^{323},{ }^{324},{ }^{325},{ }^{326},{ }^{327}$, $328,329,330,331,332,333,334$.

${ }^{323}$ Бачинська I. А. Формування англомовної мінгвосоціокультурної компетенції учнів старшої школи: Аис. ... канА. пеА. наук: 13.00.02. Херсон, 2015. 217 с.

${ }^{324}$ Бережна I. В. Методика навчання майбутніх фімологів англійського писемного мовлення з використанням мовного портфеля: Аис. ... канА. пеА. наук: 13.00.02. Запоріжжя, 2012. 341 с.

325 Білоус С. В. Навчання майбутніх фімологів англійського усного монологічного персуазивного мовлення: дис. ... канА. пеА. наук: 13.00.02; КНУ імені Т. Шевченка. Київ, 2017. 228 c.

${ }^{326}$ Крисак $\Lambda$. В. Методика навчання майбутніх мікарів загальної практики англомовного професійно орієнтованого Аіалогічного мовлення: Аис. ... канА. пеА. наук: 13.00.02. Київ, 2016. 285 с.

${ }^{327}$ Аитвиненко I. Ю. Методика навчання студентів технічних спеціальностей англомовного читання на засадах інтеграції: Аис. ... канА. пеА. наук: 13.00.02. Херсон, 2015. 255 с.

${ }^{328}$ Михайленко О. А. Методика навчання майбутніх філологів стратегій письмового перекмаду офіційно-ділових текстів з української мови на англійську: Аис. ... канА. пеА. наук: 13.00.02. Київ, 2015. 258 с.

329 Мінь М. Методика навчання усного китайського Аіалогічного мовлення майбутніх фімологів: Аис. ... канА. пеА. наук: 13.00.02. Київ, 2018. 199 с.

${ }^{330}$ Патієвич О. В. Методика навчання стилістичної унормованості наукового писемного англійського мовлення майбутніх фізиків в умовах магістратури: Аис. канд. пеА. наук: 13.00.02; М-во освіти і науки України, Київ. нац. ун-т імені Тараса Шевченка. Київ, 2015. 276 с.

${ }^{331}$ Трикашна Ю. І. Формування англомовної соціокультурної компетентності у майбутніх філологів з використанням автентичного художнього фільму: Аис. ... канА. пеА. наук: 13.00.02. Київ, 2017. 394 с.

${ }^{332}$ Цепкало О. В. Методика навчання комунікативних стратегій професійно спрямованого англомовного писемного спіккування майбутніх фахівців 3 машинобудування: Аис. ... канА. пеА. наук: 13.00.02; НТУ КПІ імені І. Сікорського. Київ, 2017. 244 с.

${ }^{333}$ Шиліна Г. А. Методика дистанційного навчання української мови учнів основної школи: дис. ... канА. пеА. наук: 13.00.02; БерАян. Аерж. пеА. ун-т. Київ, 2016. 300 с.

${ }^{334} \mathrm{Al}$-Ghanimi Q., Jameel Rashid. Teaching reading English academic texts to philology students: Ph. D. thesis: 13.00.02. Kyiv, 2017. 323 p. 
Мета методичного експерименту полягає у перевірці ефективності авторської методики Аистанційного навчання англійського аргументативного письма стуАентів-юристів у таких жанрах юридичного Аискурсу як мист-порада, меморандум, Аист-попереАження, кист-віАповіАь на попереАження, позовна заява на основі визначених підходів, принципів та методів навчання 3 урахуванням особливостей електронного Аистанційного навчання на базі систем керування навчанням. Мета експерименту обумовлює вирішення наступних завАань:

1) сформувати експериментальні групи однакові за кількістю та рівнем сформованості умінь англійського аргументативного письма шияхом проведення передекспериментального зрізу;

2) підготувати навчальні матеріали експерименту, спланувати процедуру проведення експерименту;

3) перевірити технічну готовність сайту Аистанційного навчання Київського націонацьного університету імені Тараса Шевченка (https://dl.knu.ua/), а саме: завантажити всі необхідні матеріали на сайт, зробити необхіАні налаштування, зареєструвати учасників експерименту;

4) провести експериментальне навчання за авторською методикою;

5) провести післяекспериментальний зріз у студентів з метою визначення їх рівня сформованості умінь ангАійського аргументативного письма;

6) проаналізувати отримані дані та за допомогою статистичних методів довести або спростувати ефективність авторської методики Аистанційного навчання ангАійського аргументативного письма студентів-юристів.

ПіА час перевірки авторської методики Аистанційного навчання англійського аргументативного письма був провеАений методичний експеримент, який можна охарактеризувати 
як природній (проводився у звичних умовах), констатуючий (встановлюється існування причинно-наслідкових зв'язків між впливом на об'єкт АосліАження і Аосягнутим результатом), скмаАний за структурою АосліАжуваних об’єктів та явищ та інформаційний за характером зовнішнього впливу на об'єкт Аослідження.

Тривалість експерименту була обумовцена авторською модемлю, описаною у піАрозАілі 2.4, і скмадала 60 позааудиторних годин безпосереАньо Аистанційного навчання. Проте, експеримент охоплював передекспериментальний і післяекспериментальний зрізи, на які віАводилося 4 аудиторні години. Отже, в цілому експеримент тривав 64 години. Експериментальне навчання провоАилося на базі юридичного факультету Київського національного університету імені Тараса Шевченка у 2017-2018 н.р.

Об'єктом експериментального Аослідження стали уміння студентів-юристів продукувати ангАійське аргументативне письмо.

Суб'єктами експерименту були студенти першого року навчання ОР «Бакалавр» спеціальності 081 «Право», які навчамися на юридичному факультеті Київського національного університету імені Тараса Шевченка. В цілому участь в експерименті взяли 52 студенти (2 експериментальні групи з базовим рівнем навченості не нижче В1 по 26 осіб в кожній). Аобір учасників експерименту віАбувався у Ава етапи. На першому етапі, у якому взяли участь 75 студентів I курсу юриАичного факультету Київського національного університету імені Тараса Шевченка, ми відібрали тих студентів, загальний рівень навченості яких був не нижче В1. За резумьтатами Аругого етапу ми сформували дві однакові за кількістю та рівнем навченості експериментацьні групи.

Неварійованими умовами навчання в експериментальних групах піА час експерименту були: 
- скмаА експериментальних груп (ЕГ): оАнаковий за кількісним показником та рівнем сформованості умінь англійського аргументативного письма Ао початку експериментального навчання;

- тематика, мовний матеріац, цілі та зміст навчання англійського аргументативного письма;

- зміст передекспериментального і післяекспериментального зрізів;

- об’єкти контролю та критерії оцінювання рівня сформованості умінь англійського аргументативного письма.

Варійованою умовою експерименту була технологія Аистанційного навчання, на основі якої відбувалося навчання англійського аргументативного писемного мовлення. Варіант А: Студенти ЕГ-1 навчалися на платформі LMS Moodle в умовах керованого навчання із використанням аАміністративних, навчальних та комунікативних інструментів системи, що Аозвомило нам вести спостереження, анкетування та опитування, за результатами яких ми мали можливість наАавати піАтримку задля уникнення чи подолання предметних, могічних та/чи мовних труднощів. Варіант Б: Навчання студентів ЕГ-2 відбува-

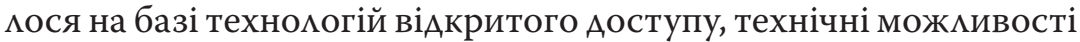
яких Аозволяють преАставити навчальний матеріал в повному обсязі, однак унеможливлюють спостереження за навчальним процесом, тим самим робцять процес контролю знань, навичок та умінь умовним.

Аналіз теоретичних праць $з$ методики, педагогіки, мінгвістики, психології та психолінгвістики, а також педагогічні спостереження за процесом навчання юридичної англійської мови студентів-юристів Аозволили нам висунути гіпотезу, яка грунтується на припущенні, що висока ефективність Аистанційного навчання англійського аргументативного письма Аосягається за таких умов: 
- організація навчання зАійснюється на засадах конструктивістського, компетентнісного та жанрового піАходів, а також у віАповіАності до АиАактичних, психологічних та методичних принципів, визначених в піАрозАілі 1.3 цього АосліАження;

- використання методу Сократа та кейс-методу;

- організація навчання на основі таких жанрів англійського аргументативного письма як кист-порада, кист-попереАження, Аист-віАповідь на попереАження, меморандум, позовна заява;

- використання піАсистеми вправ і завдань, преАставленої в піАрозділі 2.3 цієї монографічної роботи;

- використання аАміністративних, навчальних та комунікативних інструментів платформи Moodle;

- застосування моделі авторської методики Аистанційного навчання англійського аргументативного письма, описаної в підрозАілі 2.4 цієї монографії.

Пиан та структура експерименту. Експериментальне навчання англійського аргументативного письма віАбувалося за структурою, преАставленою у таблиці 3.1.1:

3 метою уникнення факторів, які можуть впливати на точність провеАення та результати Аослідження, нами були виконані наступні превентивні Аіï:

1) створення рівних за кількістю та рівнем навчаеності експериментальних груп за результатами передекспериментацьного зрізу;

2) скмадання контрольних завдань Аля Авох груп однаковими за формою контролю - письмові, тривацістю виконання - 60 хвицин, та рівними за ступенем скмаАності.

3) Завдання перевірялися одним викмадачем - експериментатором у віАповіАності Ао чітко встановцених критеріїв. 
Табциця 3.1.1 - Структура експериментального навчання ангАійського аргументативного письма

\begin{tabular}{|c|c|c|c|c|c|}
\hline № & $\begin{array}{c}\text { Етап } \\
\text { експериментахь- } \\
\text { ного дослідження }\end{array}$ & $\begin{array}{c}\text { Час прове- } \\
\text { Аення }\end{array}$ & 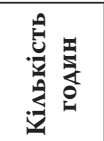 & 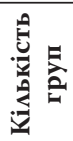 & $\begin{array}{c}\text { Завдання } \\
\text { етапу }\end{array}$ \\
\hline 1. & $\begin{array}{c}\text { Передексперимен- } \\
\text { тальний } \\
\text { зріз }\end{array}$ & $\begin{array}{c}\text { Березень } 2018 \\
\text { н.р. }\end{array}$ & $\begin{array}{c}2 \\
\text { години }\end{array}$ & 2 & $\begin{array}{l}\text { Визначення вихідного } \\
\text { рівня сформованості умінь } \\
\text { англійського аргументатив- } \\
\text { ного письма; формування } \\
\text { експериментальних груп, } \\
\text { однакових за кількістю та } \\
\text { рівне навченості. }\end{array}$ \\
\hline 2. & $\begin{array}{c}\text { Експериментальне } \\
\text { навчання }\end{array}$ & $\begin{array}{l}\text { Березень-тра- } \\
\text { вень } 2018 \text { н.р. }\end{array}$ & $\begin{array}{c}60 \\
\text { годин }\end{array}$ & 2 & $\begin{array}{lr}\text { Реалізація } & \text { авторської } \\
\text { методики } & \text { Аистанційного } \\
\text { навчання } & \text { англійського } \\
\text { аргументативного письма } \\
\begin{array}{l}\text { в роботі ЕГ1. } \\
\end{array}\end{array}$ \\
\hline 3. & $\begin{array}{c}\text { Післяексперимен- } \\
\text { тальний } \\
\text { зріз }\end{array}$ & $\begin{array}{c}\text { Травень } 2018 \\
\text { н.p. }\end{array}$ & $\begin{array}{c}2 \\
\text { годин }\end{array}$ & 2 & $\begin{array}{l}\text { Визначення підсумкового } \\
\text { рівня сформованості умінь } \\
\text { англійського аргументатив- } \\
\text { ного письма студентів-ю- } \\
\text { ристів в ЕГ1 та ЕГ2. }\end{array}$ \\
\hline
\end{tabular}

Щоб навчання було ефективним, а результати - чіткими i Аостовірними, важливим аспектом експерименту залишається процес спостереження за його ходом. Як зазначають С.О. Сисоєва та Т.Є. Кристопчук, педагогічне спостереження забезпечує теоретичне дослідження емпіричною інформацією, іншими словами, воно перевіряє аАекватність та істинність теорії в практиці ${ }^{335}$.

У ході спостереження за навчанням експериментальних груп, яке віАбувалося на платформі Moodle, ми не могли зАійснювати звичне спостереження у реальному часі за його об'єктом - Аіями студентів. Тим не менше, за допомогою аАміністративних інструментів LMS Moodle ми фіксували час

${ }^{335}$ Сисоєва С. О., Кристопчук Т. Є. Методологія науково-педагогічних Аосліджень: підручник. Рівне: Волинські обереги, 2013. С. 115. 
роботи студента в системі, кількість годин, витрачених на виконання того чи іншого завдання, аналізували журнал оцінок студентів та звіти про їх діяльність за визначений проміжок часу. Аані графіки в автоматичному режимі показували успішність студента по віАношенню Ао його власних результатів та порівнювали 3 результатами інших студентів. Таким чином, Аана інформація дозволяла нам виявляти студентів, Аля яких матеріал був занаАто скмаАним, та вчасно надавати їм консультацію (Аистанційно, за Аопомогою сервісу Обмін повідомленнями), забезпечувати необхідним Аодатковим матеріалом чи тренувальними вправами.

Аля виявцення якісних та кількісних результатів експериментального навчання нами були сформумьовані критерії та стандарти (норми) оцінювання умінь ангАійського аргументативного письма студентів-правників віАповіАно до чинної Програми 3 англійської мови Аһя професійного спілкування ${ }^{336}$ та 3 урахуванням міжнародних вимог, визначених Аля оцінки знань англійської мови як іноземної (The International English Language Testing System - IELTS, tests for the Cambridge Certificate of Advanced English - CAE and Certificate of Proficiency in English - CPE, Test of English as a Foreign Language - TOEFL, test for the International Legal English Certificate - ILEC, Test of Legal English Skills - TOLES). Щоб оцінювання було якісним і об'єктивним мише критеріїв не Аостатньо. Важливо було також прописати норми (або стандарти) оцінювання умінь та навичок, аАже сформульовані критерії визначають якість корисності, але не роблять жодних припущень щодо їі фактичної якості, в той час як стандарти (норми) стосуються визначених рівнів

${ }^{336}$ Програма 3 англійської мови Аця професійного спілкування. Колектив авторів: Г. Є. Бакаєва, О. А. Борисенко, І. І. Зуєнок, В. О. Іваніщева, А. Й. КАименко, Т. І. Козимирська, С. І. Кострицька, Т. І. Скрипник, Н. Ю. Тодорова, А. О. Ходцева. Київ: Аенвіт, 2005. 119 c. 
якості або досягнення. Таким чином, слідом за австраційським вченим Ройсом Седлером (D. Royce Sadler) розуміємо поняття «критерій» як «властивість або характеристику, за якою можна оцінити якість чогось» ${ }^{337}$, а поняття «стандарт» (у вітчизняній науково-методичній мітературі вживається термін «норма») як «певний рівень Аосягнень, який прагнуть Аосягнути або Аосягають» ${ }^{338}$.

Аналіз наукових праць та міжнародних вимог, присвячених оцінюванню умінь іншомовного писемного мовлення на рівні $\mathrm{B} 2^{339},{ }^{340},{ }^{341},{ }^{342}, 343,{ }^{344}$, Аав можмивість сформулювати наступні критерії Аля оцінювання англійського аргументативного письма студентів-правників:

- змістовність висловлювання: віАповідність темі, повнота розкриття теми, трактування питання через

${ }^{337}$ Sadler D. R. Specifying and promulgating achievement standards // Oxford Review of Education. 1987. No 13. P. 191-209.

${ }^{338}$ Так само.

${ }^{339}$ Бережна I. В. Методика навчання майбутніх філологів англійського писемного мовцення з використанням мовного портфеля: Аис. ... канА. пеА. наук: 13.00.02. Запоріжжя, 2012. С. 148-149.

${ }^{340}$ Бех П. О., Биркун А.В. Концепція викладання іноземних мов в Україні. Іноземні мови. 1996. № 2. С. 3-8.

${ }^{341}$ Патієвич О. В. Методика навчання стилістичної унормованості наукового писемного англійського мовмення майбутніх фізиків в умовах магістратури: Аис. ... канА. пеА. наук: 13.00.02; М-во освіти і науки України, Київ. нац. ун-т імені Тараса Шевченка. Київ, 2015. С. 67-72.

${ }^{342}$ Програма 3 англійської мови Аля професійного спілкування. Комектив авторів: Г. Є. Бакаєва, О. А. Борисенко, І. І. Зуєнок, В. О. Іваніщева, А. Й. Кцименко, Т. І. Козимирська, С. І. Кострицька, Т. І. Скрипник, Н. Ю. Тодорова, А. О. Ходцева. Київ: Аенвіт, 2005. C. 23-24.

${ }^{343}$ Цепкало О. В. Методика навчання комунікативних стратегій професійно спрямованого англомовного писемного спілкування майбутніх фахівців 3 машинобудування: Аис. ... канА. пеА. наук: 13.00.02; НТУ КПІ імені І. Сікорського. Київ, 2017. С. 127-132.

${ }^{344}$ Cambridge English. Assessing Writing Performance. Level B2. URL: http://www.cambridgeenglish.org/images/cambridge-english-assessing-writing-performance-at-level-b2.pdf. 
призму різноманітних іАей та аргументів, самостійність і ретельність інтерпретації теми, узгодженість із діючими законодавчими нормами та правовою практикою;

- аргументованість та структурованість висловлювання: віАповіАність законам могічної аргументації, чіткість формулювання тези, аргументів, Аемонстрації, могічна послідовність викмаду, Аостатність і адекватність використання засобів зв'язку, правильність організації абзаців;

- лексичний діапазон та технічнеобормлення: різноманітність мексики, Аексична коректність та доречність використання мексичних одиниць/термінів/ідіом, стильова адекватність вибору мексичних одиниць у віАповідності Ао юридичної тематики, відсутність необгрунтованого повторення слів, правицьність орфографії та переносу слів, правильність пунктуації та капітацізації;

- граматична коректність: різноманіття граматичних структур, адекватне використання граматичних структур, коректність вживання форм Аієслова активного та пасивного стану, а також артикців, займенників, прийменників, числових форм іменника, ступенів порівняння прикметника і прислівника, узгодження часів та правильність порядку слів;

- адекватна стилістична забарвленість (реєстр i бормат висловлювання): чутливість до читача (соціальні ролі, тип повідомлення), формат, що відповідає завданню, віАповіАний регістр.

На основі визначених критеріїв були сформульовані норми (стандарти) оцінювання умінь англійського аргументативного письма студентів-правників. Аця зручності сприйняття преАставимо їх в таблиці 3.1.2 із зазначенням критерію, балів та віАповіАних умінь та навичок. 
Таблиця 3.1.2 - Стандарти (норми) оцінювання навичок англійського аргументативного письма студентів-юристів

\begin{tabular}{|c|c|c|}
\hline Критерій & Бами & Норми (стандарти) \\
\hline 1 & 2 & 3 \\
\hline \multirow{6}{*}{ 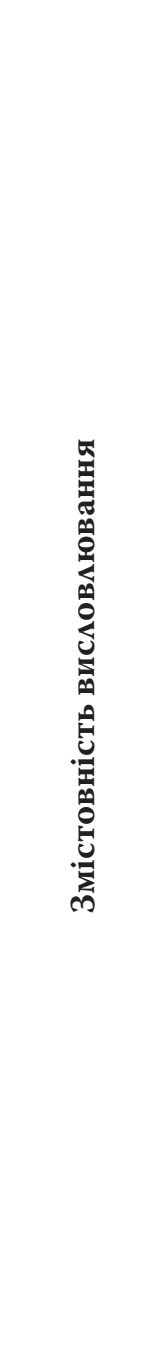 } & 5 & $\begin{array}{l}\text { Зміст письмового тексту цілком віАповіАає } \\
\text { поставленому завданню. Тема вичерпно } \\
\text { розкрита. Професійна інформація та дані узгод- } \\
\text { жуються із Аіючим законодавством та загаль- } \\
\text { ноприйнятою юридичною практикою. Текст } \\
\text { представляє індивідуальне (не шаблонне), проте } \\
\text { оптимальне вирішення правової задачі. }\end{array}$ \\
\hline & 4 & $\begin{array}{l}\text { Зміст письмового тексту відповіАає поставле- } \\
\text { ному завданню та розкриває кАючові вимоги. } \\
\text { Професійна інформація та дані не суперечать } \\
\text { Аіючому законодавству та загальноприйнятій } \\
\text { юридичній практиці. ПіАходи до вирішення } \\
\text { правового питання є стандартними (студент не } \\
\text { демонструє індивідуального бачення). }\end{array}$ \\
\hline & 3 & 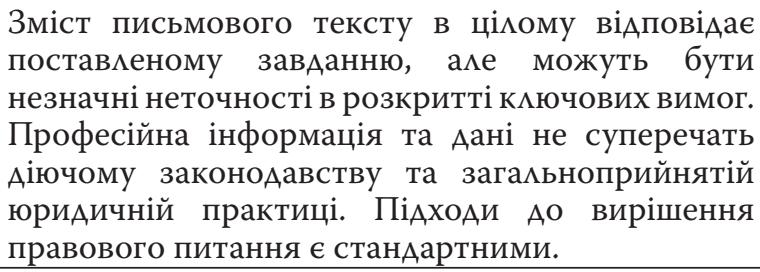 \\
\hline & 2 & $\begin{array}{l}\text { Зміст письмового тексту не зовсім відповіАає } \\
\text { постав еному завданню, хибно його інтерпретує. } \\
\text { Професійна інформація та дані можуть Аещо } \\
\text { суперечити Аіючому законодавству та загаль- } \\
\text { ноприйнятій юридичній практиці. Правова } \\
\text { проблема, поставлена в завАанні, повністю не } \\
\text { вирішена, хоча представлені можливі шляхи } \\
\text { розв'язання. }\end{array}$ \\
\hline & 1 & $\begin{array}{l}\text { Зміст письмового тексту не віАповіАає завданню. } \\
\text { Професійна інформація та дані можуть супере- } \\
\text { чити діючому законодавству та загальноприйнятій } \\
\text { юридичній практиці. Правова проблема, постав- } \\
\text { мена в завданні, повністю не вирішена. }\end{array}$ \\
\hline & 0 & Виконання нижче стандарту балу 1. \\
\hline
\end{tabular}


Продовження таблиці 3.1.2

\begin{tabular}{|c|c|c|}
\hline 1 & 2 & 3 \\
\hline \multirow{4}{*}{ 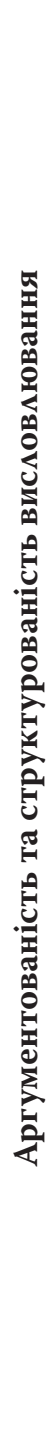 } & 5 & 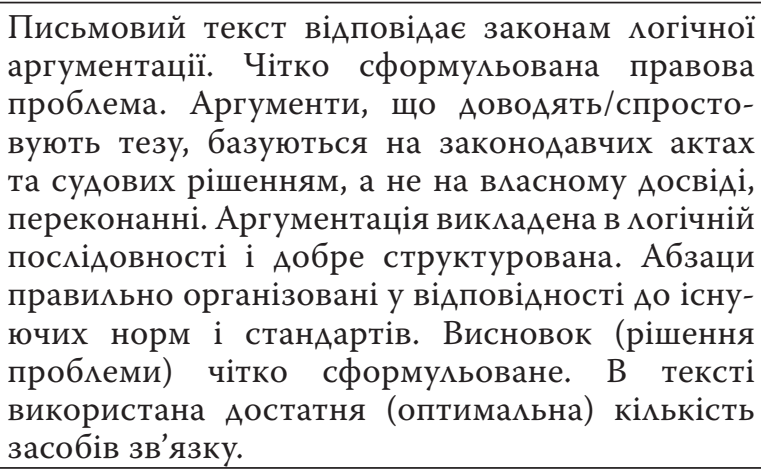 \\
\hline & 4 & $\begin{array}{l}\text { Письмовий текст в цілому відповідає законам } \\
\text { могічної аргументації. Аосить чітко сформульо- } \\
\text { вана правова проблема. Аргументи, що Аово- } \\
\text { Аять/спростовують тезу, базуються на зако- } \\
\text { нодавчих актах та судових рішенням, а не на } \\
\text { власному досвіді, переконанні. Аргументація } \\
\text { викладена досить могічно і структуровано. } \\
\text { Абзаци правильно організовані у відповіА- } \\
\text { ності до існуючих норм і стандартів. Висновок } \\
\text { (рішення проблеми) сформульоване. В тексті } \\
\text { використана достатня кількість засобів зв'язку. }\end{array}$ \\
\hline & 3 & $\begin{array}{l}\text { Письмовий текст в цілому віАповіАає законам } \\
\text { могічної аргументації. Існують неточності щодо } \\
\text { формулювання правової проблеми, аргументів } \\
\text { чи висновків. Аргументи, використані Аля Аове- } \\
\text { дення/спростовання тези, базуються на зако- } \\
\text { нодавчих актах та судових рішенням, а не на } \\
\text { власному досвіАі, переконанні. Аргументація } \\
\text { викцадена досить Аогічно і структуровано. } \\
\text { Абзаци правильно організовані у віАповіАності } \\
\text { до існуючих норм і стандартів. В тексті викори- } \\
\text { стана достатня кількість засобів зв'язку. }\end{array}$ \\
\hline & 2 & $\begin{array}{l}\text { Письмовий текст містить невіАповіАність } \\
\text { законам могічної аргументації. Існують неточ- } \\
\text { ності щодо формулювання правової проблеми, }\end{array}$ \\
\hline
\end{tabular}


Продовження таблиці 3.1.2

\begin{tabular}{|c|c|c|}
\hline 1 & 2 & 3 \\
\hline & 2 & $\begin{array}{l}\text { аргументів чи висновків. Аргументи, викори- } \\
\text { стані Аля Аоведення/спростовання тези, можуть } \\
\text { базуватися на власному досвіАі, переконанні. } \\
\text { Аргументація викладена досить Аогічно і струк- } \\
\text { туровано. Абзаци не організовані у віАповідності } \\
\text { до існуючих норм і стандартів. В тексті викори- } \\
\text { стана мінімальна кількість засобів зв'язку. }\end{array}$ \\
\hline & 1 & $\begin{array}{l}\text { Письмовий текст не відповіАає законам могічної } \\
\text { аргументації. Не сформульована правова проб- } \\
\text { мема. Шияхи її вирішення Аргументи суперечать } \\
\text { діючому законодавству та загальноприйнятій } \\
\text { юридичній практиці. Абзаци не організовані } \\
\text { у відповідності до існуючих норм і стандартів. } \\
\text { В тексті використана мінімальна кількість } \\
\text { засобів зв'язку. }\end{array}$ \\
\hline & $\mathbf{0}$ & Виконання нижче стандарту балу 1. \\
\hline \multirow{3}{*}{ 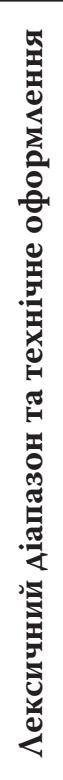 } & 5 & $\begin{array}{l}\text { В письмовому тексті представлене широке } \\
\text { різноманіття Аексики, яка вжита природно та } \\
\text { гармонійно. Продемонстрований високий рівень } \\
\text { використання професійної цексики. Вживання } \\
\text { юридичних термінів виправдане і не обтяжує } \\
\text { сприйняття. Аопускається 1-2 орфографічні } \\
\text { помилки на рівні «описка». }\end{array}$ \\
\hline & 4 & $\begin{array}{l}\text { В письмовому тексті представлене Аосить } \\
\text { широке лексичний діапазон. Продемонстро- } \\
\text { ваний достатній рівень використання профе- } \\
\text { сійної мексики. Вживання юридичних термінів } \\
\text { виправдане і не обтяжує сприйняття. Орфогра- } \\
\text { фічних помилок не більше 5. }\end{array}$ \\
\hline & 3 & $\begin{array}{l}\text { В письмовому тексті вжитий обмежений } \\
\text { Аіапазон мексичних одиниць. В основному } \\
\text { мексичні одиниці вжиті Аоречно. Вживання } \\
\text { юридичної термінології не Аосконале. Присутні } \\
\text { помилки в значенні, що призводить Ао част- } \\
\text { кового нерозуміння повідомлення. Частими } \\
\text { є орфографічні помилки. }\end{array}$ \\
\hline
\end{tabular}


Закінчення таблиці 3.1.2

\begin{tabular}{|c|c|c|}
\hline 1 & 2 & 3 \\
\hline & 2 & $\begin{array}{l}\text { В письмовому тексті вжитий мінімальний } \\
\text { Аіапазон мексичних одиниць, багато орфогра- } \\
\text { фічних помимок. Юридична термінологія пред- } \\
\text { ставлена слабо або в невірному значенні. }\end{array}$ \\
\hline & 1 & $\begin{array}{l}\text { В письмовому тексті вжитий мінімацьний } \\
\text { Аіапазон мексичних одиниць, частими є орфо- } \\
\text { графічні помилки. Використання юридичної } \\
\text { термінології віАсутнє. }\end{array}$ \\
\hline & $\mathbf{0}$ & Виконання нижче стандарту бацу 1. \\
\hline \multirow{6}{*}{ 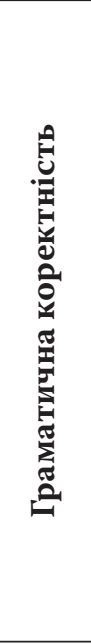 } & 5 & $\begin{array}{l}\text { Вжитий широкий Аіапазон граматичних структур } \\
3 \text { цілковитою природною гнучкістю та точністю. } \\
\text { Аопускається 1-2 помилки на рівні «описки». }\end{array}$ \\
\hline & 4 & $\begin{array}{l}\text { Вжитий широкий } \text { Аіапазон граматичних } \\
\text { структур. Переважна більшість речень } є \text { грама- } \\
\text { тично правильна. }\end{array}$ \\
\hline & 3 & $\begin{array}{l}\text { Вжитий Аостатній Аіапазон граматичних } \\
\text { структур. Граматичні помилки є Аосить частими, } \\
\text { що ускцаднює розуміння та/або призводить Ао } \\
\text { неоднозначності. }\end{array}$ \\
\hline & 2 & $\begin{array}{l}\text { Граматичні } \text { структури, вжиті в письмовому } \\
\text { тексті, } \epsilon \text { простими. Граматичні помикки } \\
\epsilon \text { частими, що ускиаднює розуміння та/або } \\
\text { призводить до неоднозначності. }\end{array}$ \\
\hline & 1 & $\begin{array}{l}\text { Правильні граматичні форми та структури } \\
\text { зустрічаються мише у фразах-кліше. }\end{array}$ \\
\hline & 0 & Виконання нижче стандарту балу 1. \\
\hline \multirow{6}{*}{ 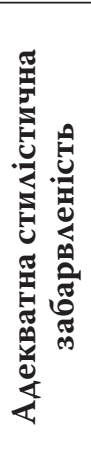 } & 5 & $\begin{array}{l}\text { Формат письмового тексті повністю віАповіАає } \\
\text { стилістиці завдання, вжитий віАповіАний регістр. }\end{array}$ \\
\hline & 4 & $\begin{array}{l}\text { Формат письмового тексту в основному віАповіАає } \\
\text { стиАістиці завАання, вжитий віАповіАний регістр. }\end{array}$ \\
\hline & 3 & $\begin{array}{l}\text { Формат письмового тексті частково віАповіАає } \\
\text { сти^істиці завдання, вжитий віАповіАний регістр. }\end{array}$ \\
\hline & 2 & $\begin{array}{l}\text { Формат письмового тексті частково віАповіАає } \\
\text { стилістиці завАання, не вжитий віАповіАний регістр. }\end{array}$ \\
\hline & 1 & $\begin{array}{l}\text { Формат письмового тексті в основному не віАпо- } \\
\text { віАає стилістиці завАання, не вжитий віАпо- } \\
\text { віАний регістр. }\end{array}$ \\
\hline & 0 & Виконання нижче стандарту балу 1. \\
\hline
\end{tabular}


Таким чином, максимахьна кількість балів, яку студент може отримати за виконання завдання на перевірку умінь англійського аргументативного письма, - 25. ВіАповіАно до загацьноєвропейської шкали оцінювання ECTS, ми визначали рівень сформованості навички як високий, за умови правильного виконання 90-100\% завдання, Аостатній - 75-89\%, сереАній - 60-74\%, початковий $-59 \%$ і нижче. ВіАсутність знань, навичок та умінь ми констатували за умови привильного виконання $10 \%$ завдання і менше. ВіАсоток кожного студента, що віАповіАає його рівню сформованості умінь англійського аргументативного письма, ми вираховували за формулою: $\mathbf{B}=\mathbf{4}$ : $\mathbf{5}$, де $\mathbf{B}-$ це віАсоток, що відповідає рівню сформованості умінь англійського аргументативного письма, Б - отримані студентом бали за виконане завдання, відповідно до критеріїв і стандартів зазначених вище.

Розглянуті вище організаційні аспекти піАготовки та етапи проведення експерименту є наАзвичайно важливими в питаннях розуміння його суті. Проте встановцювати ступінь ефективність запропонованої методики ми можемо мише після ретельного аналізу та інтерпретації результатів всіх етапів експериментального навчання. Що і стане преАметом нашого вивчення у наступному піАрозАілі.

\section{2 Анаміз та інтерпретація резуиьтатів експерименту}

Проаналізуємо отримані результати експериментального навчання 3 метою визначення рівня ефективності запропонованої методики Аистанційного навчання англійського аргументативного письма.

ВіАповідно ао структури експерименту, описаної в п. 3.1 цього АосліАження, Аля визначення вхідного рівня сформова- 
ності умінь ангАійського аргументативного письма у студентів-юристів, був проведений передекспериментальний зріз, участь у якому взяли 75 студентів I курсу OP «Бакалавр» юриАичного факультету Київського національного університету імені Тараса Шевченка. Передекспериментацьний зріз скмадався 3 Авох блоків. Завдання Блоку 1 були спрямовані на визначення загального рівня англійської мови у студенів. Ааний етап зумовлювався тим, що формування умінь англійського аргументативного письма вимагає рівня володіння англійською мовою не нижче B1, а тому студенти, що його не Аосягли, не могли брати участь в експерименті, щоб забезпечити чистоту результатів експериментацьного навчання. За результатами вхіАного тестування ми віАібрали 56 студентів, рівень навченості яких був не нижче В1.

Наступний етап передекспериментацьного зрізу був спрямований на визначення рівня сформованості у студентів умінь англійського аргументативного письма. Студенти одержали завдання Блоку 2, яке полягало у написанні одного із запропонованих текстів у визначених жанрах в межах юридичного Аискурсу. Зміст завдання наводимо Аалі:

Study the situations below and write one of the texts following its instructions.

1. You have invited a training agency to deliver a day's training course for your employees on Contract Law.

Write a memorandum (in 200-250 words) to your employees to tell them about the event. Your memorandum should:

- explain the reason(s) for organizing the training day

- inform them of the main content of the course

- give details of times

- indicate what action they should take on receiving the memo, including any questions on Contract Law for the trainers. 
2. Read the situation below. You are Miss Peterson's lawyer. Write a letter of advice (in 200-250 words) to your client explaining whether she is obliged to pay or not.

Kate Peterson is Michael Brown's girlfriend. The relationship started six months ago. Michael offers Kate to go to Switzerland on a holiday. Kate accepted. Michael pays for the holiday on his credit card. The cost is 3000 USD in total. However, a week before the holiday Kate breaks their relationship and says that she doesn't want to go on holiday. Michael is very angry and demands 1500 USD from Kate. She says she thinks the holiday was a present from him.

Роботи студентів оцінювалися за 5 критеріями, визначеними у п. 3.1 нашого Аослідження, а саме: змістовність висловАювання, аргументованість та структурованість висловлювання, ^ексичний Аіапазон та технічне оформлення, граматична коректність, адекватна стилістична забарвленість. Коефіцієнт навченості обчислювався за формулою В.П. Беспалька ${ }^{345}$ : $\mathrm{K}=\mathrm{Q} / \mathrm{N}$, Ае K - коефіцієнт правильності; Q 一 кількість отриманих студентом балів; $\mathrm{N}$ - максимально можмива кількість балів. ВіАповіАно, рівень виконання завдання вважається задовільним за умови, якщо коефіцієнт К не менше 0,7.

ПереАекспериментальний зріз виявив такі результати: 17 студентів 3 низьким рівнем сформованості умінь англійського аргументативного письма, 27 студентів - сереАнього рівня, 11 - Аостатнього, 1 студент мав високий рівень. Аля чистоти та об'єктивності нашого експерименту, за результатами передекспериментального зрізу ми сформували Аві оАнакові за рівнем навченості експериментацьні групи по 26 студентів, 3 яких 5 студентів - мають достатній рівень сформованості умінь англійського аргументативного письма, 13 студентів сереАній, 8 - низький рівень.

\footnotetext{
${ }^{345}$ Беспалько В. П. Опыт разработки и использования критериев качества усвоения знаний // Советская педагогика. 1968. № 4. С. 56.
} 
Розглянемо та проанацізуємо результати передекспериментального зрізу в ЕГ-1 та ЕГ-2.

Так, середній бал групи ЕГ-1 за критерієм «змістовність висловлювання» становить 2,85, за критерієм «аргументованість та структурованість висловлювання» - 2,42, за критерієм «лексичний Аіапазон та технічне оформлення» - 2,92, за критерієм «граматична коректність» - 3,23, за критерієм «адекватна стилістична забарвленість» - 3,42. Загальний бал групи ЕГ-1 становить 14,84 з максимальних 25 балів. ВіАповіАно сереАній коефіцієнт навченості в групі ЕГ-1 склав 0,59 (Аодаток Г1).

Передекспериментальний зріз в ЕГ-2 (Аодаток Г2) показав наступні результати: середній бал групи за критерієм «змістовність висловлювання» становить 2,89, за критерієм «аргументованість та структурованість висловлювання» - 2,46, за критерієм «лексичний Аіапазон та технічне оформлення» - 2,96, за критерієм «граматична коректність»- 3,19, за критерієм «адекватна стилістична забарвленість» - 3,42. Загальний бал групи ЕГ-2 становить 14,92 з максимацьних 25 балів. ВіАповіАно середній коефіцієнт навченості в групі ЕГ-2 скмав 0,60.

Зіставлення одержаних результатів передекспериментального зрізу по групам ЕГ-1 та ЕГ-2 Аозволяє зробити наступні важмиві висновки: 1) коефіцієнт навченості свідчить про приблизно оАнаковий рівень сформованості умінь англійського

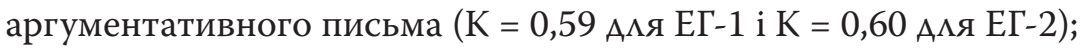
2) рівень сформованості умінь англійського аргументативного письма $є$ недостатній, аАже менший за $\mathrm{K}=0,7$.

Аалі проаналізуємо роботи учасників передекспериментального зрізу віАповіАно Ао кожного критерію.

Аналіз робіт за критерієм «змістовність висловлювання» виявив неАостатній коефіцієнт навченості ( $\mathrm{K}=0,57$ в ЕГ-1 та $\mathrm{K}=0,58$ в ЕГ-2). I хоча у переважної більшості студентів зміст письмового тексту віАповіАав поставценому завданню, все 
ж були Аеякі неточності в розкритті кмючових питань. Зокрема, юриАичні дані дещо суперечили Аіючому законодавству та загальноприйнятій юридичній практиці, а правова проблема, поставлена в завданні, повністю не була вирішена, хоча і були преАставлені можмиві шляхи іï розв'язання. Так, переважна більшість студентів не змогла окреслити основні елементи забов'язуючого Аоговору та їх основні характеристик. Таким чином, основними неАоліками письмових текстів за критерієм «змістовність висловлювання» були: недостатня повнота розкриття теми, однаковість в підході до інтерпретації існуючої інформації та неузгодженість із Аіючими законодавчими нормами та правовою практикою.

Аналіз письмових текстів за критерієм «аргументованість і структурованість висловлювання» Аозволив Аійти наступних висновків. Коефіцієнт навченості в обох групах $\epsilon$ недостатнім ( $\mathrm{K}=0,48$ в ЕГ-1 та $\mathrm{K}=0,49$ в ЕГ-2). Переважна більшість студентів $(84 \%)$ не змогли вірно сформулювати тезу. Крім того, часто аргументи базувацися на власному життєвому досвіді студентів і не були підкріплені посиланнями на законодавство та/чи судову практику, що призводимо Ао неправильних висновків. Таким чином, констатуємо, що в текстах спостерігалася невіАповіАність законам могічної аргументації, що проявцялася в неточностях щодо формулювання тези, аргументів та/чи висновків. Тим не менше, зауважимо, що студенти в більшості продемонстрували достатній рівень використання засобів зв'язку, що помегшувало сприйняття інформації: First(ly); Initially; To begin/ start with; First and most importantly; And then; Next; Formerly/ previousely; Summing up/to sum up/To conclude/in summary; Finally; In short/in brief; On the whole; In my opinion/In my view / To my mind; Alternatively; But / However; Even though / Although; On the one hand / On the other hand. ОАнак, вагомі недоліки спостерігалися в структурованості висловлювань та організації 
абзаців. Зокрема, піА час написання миста-поради студенти «пропускали» такі обов'язкові його композиційні елементи як «короткий викмад фактів» та «пропозиція наступних Аій».

Анаціз робіт за критерієм «лексичний Аіапазон та технічне оформлення» виявив неАостатній рівень навченості: $\mathrm{K}=0,58$ в ЕГ-1 та $\mathrm{K}=0,59$ в ЕГ-2. Констатуємо, що в письмових текстах вжитий обмежений Аіапазон мексичних одиниць, характерних А^я визначених жанрів ангмійського аргументативного письма; наявні помилки в значенні деяких термінів (consideration; warranty/condition; termination; assignment; jointly liable; injunction; damages; restitution; remedy), що призводили Ао часткового нерозуміння повідомлення; присутні орфографічні помикки (enforcable (правильно: enforceable); worranty (правильно:

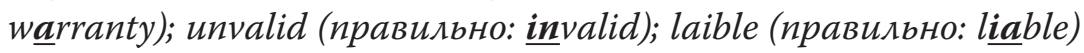
); неправильне вживання прийменників у таких фразах як parties to a contract, under a contract, rule for/against, sue for.

Анаціз письмових текстів за критерієм «граматична коректність» виявив недостатній рівень сформованості граматичних навичок у продукуванні ангмійського аргументативного письма (К = 0,65 в ЕГ-1 та $\mathrm{K}=0,64$ в ЕГ-2). СтуАенти робили помилки у вживанні таких граматичних форм і структур: незмічувані іменники (advice; litigation); присвійний віАмінок іменника (three days' notice; the court's ruling); модальні дієслова (shall; should/ ought to; can; may; might); пасивний стан Аієслова (We have been informed by our client that ...; Our client will be fully entitled to ...); активний стан Аієслова (Recent case law suggests that ...; I am writing to summarize our discussion and to confirm your instructions); інфінітив та інфінітивні конструкції (You signed a contract stating the terms to be done.); герундій (Thank you for coming ...; ... without being liable for damages...); умовні речення I та II типів (If you choose not to sign a restriction, we will be forced to commence a proceeding immediately. If the term were simply a warranty, Mr. 
Brown would be able to claim for damages.). Констатуємо, що Аіапазон граматичних форм і структур, вжитих в текстах, не $\epsilon$ широким, а граматичні помилки не були частими в простих структурах, проте в скмаАних - призводили до неоднозначності і ускиаАнювали розуміння.

Аналіз робіт за критерієм «адекватна стилістична забарвценість» виявив неАостатній рівень навчені студентів $(\mathrm{K}=0,68)$. Констатуємо, що формат письмових текстів частково віАповідає стилістиці поставленого завдання. Зокрема, студентами частково враховувався мовний регістр, часто вживаними були скорочення типу I'll, don't, can't, won't, помилки в звертанні (Dear Ms. Kate), невіАповіАне вживання архаїчних слів (herein, thereto, hereinafter) та матинських виразів (ad hoc, inter alia, de facto).

Таким чином, аналіз результатів передекспериментального зрізу в ЕГ-1 та ЕГ-2 продемонстрував неАостатній рівень сформованості умінь англійського аргументативного письма, а аналіз письмових робіт, в свою чергу, виявив найпоширеніші помилки в продукуванні текстів віАповіАних жанрів англійського аргументативного письма. За результатами передекспериментального зрізу були сформовані рівні за кількістю та рівнем навченості експериментальні групи: ЕГ-1 та ЕГ-2 скмаАамися із 26 студентів 3 яких 5 студентів - мали достатній рівень сформованості умінь англійського аргументативного письма, 13 студентів - сереАній, 8 - низький рівень.

Аотримуючись могіки нашого АосліАження, Аалі опишемо експериментальне навчання та проаналізуємо результати післяекспериментацьного зрізу.

Експериментальне навчання віАбувалося згіАно 3 авторською модемлю Аистанційного навчання ангАійського аргументативного письма, преАставленою в п. 2.4 цієї монографії. Аистанційне навчання англійського аргументативного письма тривацо 60 позааудиторних годин, скмадалося з 5 модумів 
3 орієнтовним навантаженням 1-2 години на Аень. В експерименті взяли участь 52 студенти I курсу юридичного факультету Київського національного університету імені Тараса Шевченка, 3 них 26 студентів (ЕГ-1) навчалися Аистанційно на основі авторської моделі, що реалізовувалася в межах системи керування навчанням LMS Moodle, режим доступу: https:/dl.knu.ua/ course/view.php?id=9264. Авторська модель містить підсистему вправ та завдань на формування умінь англійського аргументативного письма, яка реалізується у чотири етапи. Навчання в системі керування навчанням переАбачало використання аАміністративних, комунікативних та навчальних інструментів платформи, що Аозволило нам вести спостереження, анкетування та опитування, за результатами яких ми мали можливість наАавати підтримку заАля уникнення чи подолання преАметних, могічних та/чи мовних труднощів. У той же час, Аистанційне навчання ангАійського аргументативного письма 26 студентів у скцаді ЕГ-2 віАбувацося на основі тієї самої піАсистеми вправ та завдань, яка реацізовувалася за Аопомогою технологій віАкритого Аоступу, технічні можАивості яких Аозволили преАставити навчальний матеріал в повному обсязі, однак унемож-

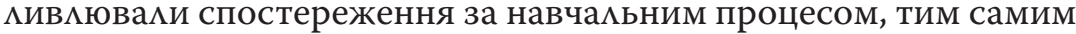
роблячи процес контролю знань, навичок та умінь умовним. За результатами навчання всі студенти отримали завдання написати оАнин із запропонованих текстів на перевірку умінь англійського аргументативного письма:

1) You are leaving your law firm to spend six month working abroad and are transferring your case load to a colleague. A client wants to sell electronic equipment to a company in another country. You have been negotiating the contract.

Write a memorandum to your colleague to brief him on the case. You memorandum should:

- give some information on the client and the deal 
- explain what points you have reached in the negotiations

- describe any problems you envisage

- outline what need to be done next.

Write your answer in 200-250 words.

2) You are a lawyer. One of your clients Jack Freeman, a citizen of the USA, has inherited a farm land in Ukraine and wants to start a business for wheat growing. He needs your advice on the best business structure for him.

Write a letter of advice to your client in 200-250 words.

Розглянемо та проаналізуємо результати післяекспериментального зрізу в ЕГ-1 та ЕГ-2.

ВіАповіАно Ао одержаних результатів (Аодаток ГЗ), сереАній коефіцієнт навченості по групі ЕГ-1 скмав 0,81. Коефіцієнт навченості 0,7 і вище мають 84,6\% студентів ЕГ-1. СереАній бал групи за критерієм «змістовність висловлювання» становить 3,88, за критерієм «аргументованість та структурованість висловлювання» - 4,12, за критерієм «лексичний Аіапазон та технічне оформлення» - 4,15, за критерієм «граматична коректність» - 3,89, за критерієм «адекватна стилістична забарвменість» - 4,19. Загальний бал групи ЕГ-1 становить 20,23 3 максимальних 25 балів. Щоб оцінити ефективність авторської методики Аистанційного навчання англійського аргументативного письма, зіставимо результати ЕГ-1 Ао і після експериментального навчання. На Рис. 3.2.1 подаємо графічне представлення зіставлення результатів переА- і післяекспериментацьного зрізів студентів ЕГ-1 по кожному критерію.

Як свідчать Аані на рис. 3.2.1 результати післяекспериментального зрізу $є$ вищими за всіма критеріями: змістовність висловлювання - на 20,6\%; аргументованість і структурованість висловлювання - на 34\%; мексичний діапазон і технічне оформлення - на 24,6\%; граматична коректність - на 13,2\%; адекватна стилістична забарвленість - на $15,4 \%$. 


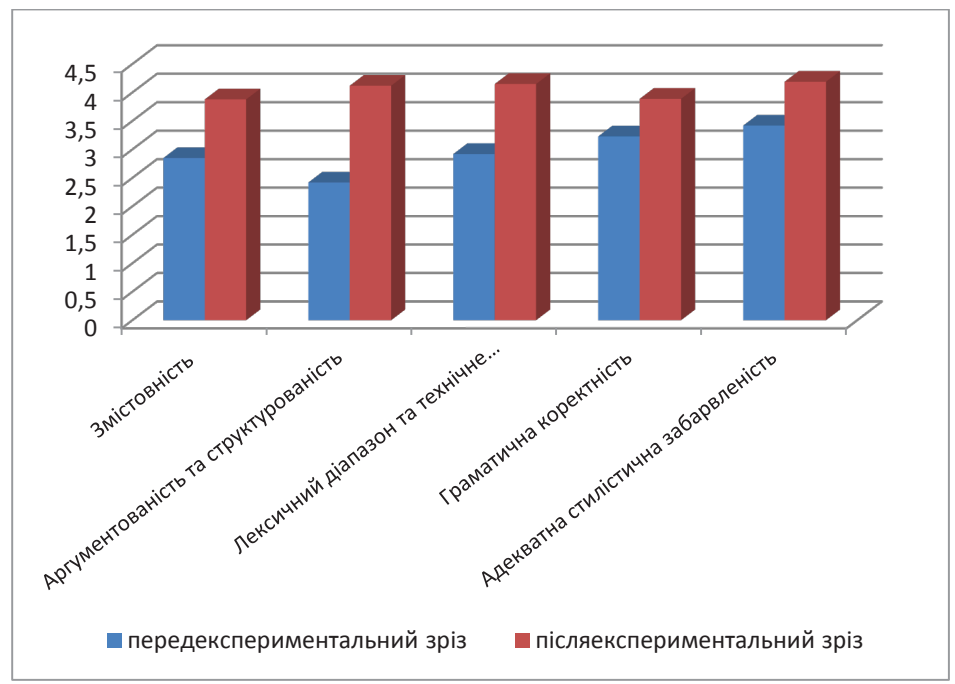

Рисунок 3.2.1 - Зіставлення результатів передекспериментамьного і післяекспериментацьного зрізів ЕГ-1

За результатами післяекспериментального зрізу ЕГ-2 маємо такідані (Аодаток Г4): коефіцієнт навченості студентів ЕГ-2 коливається віА 0,40 до 0,92 і в середньому становить 0,69. Аише 61,5\% групи подолали необхідний бар'єр $(K=0,7)$. СереАній бал групи за критерієм «змістовність висловлювання» становить 3,15, за критерієм «аргументованість та структурованість висловлювання» - 2,81, за критерієм «лексичний діапазон та технічне оформлення» - 3,62, за критерієм «граматична коректність» - 3,85, за критерієм «адекватна стилістична забарвменість» - 3,92. Загацьний бал групи ЕГ-1 становить 17,35 3 максимальних 25 балів. Щоб оцінити ефективність авторської методики Аистанційного навчання англійського аргументативного письма, зіставимо результати ЕГ-2 Ао і після експериментального навчання (рис. 3.2.2): 


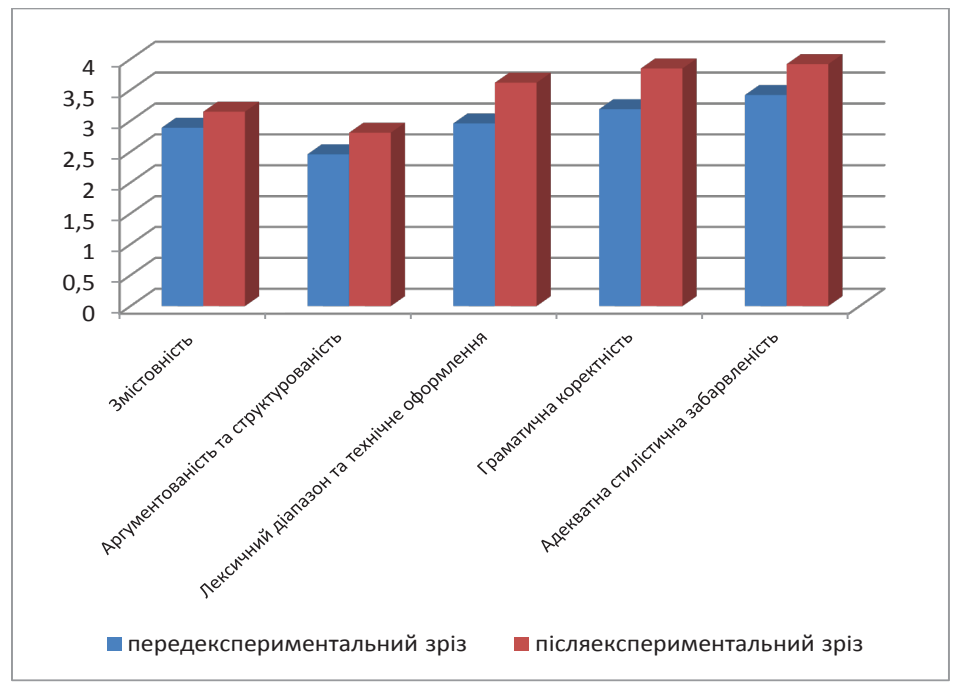

Рисунок 3.2.2 - Зіставмення резумьтатів передекспериментамьного і післяекспериментамьного зрізів ЕГ-2

За результатами післяекспериментацьного зрізу ми маємо незначне зростання за всіма критеріями: змістовність висловлювання - на 5,2\%; аргументованість і структурованість висловлювання - на 7\%; лексичний Аіапазон і технічне оформлення - на 13,2\%; граматична коректність - на 13,2\%; адекватна стилістична забарвленість - на $10 \%$.

Зіставимо та проаналізуємо результати післяекспериментального зрізу в ЕГ-1 та ЕГ-2 (рис. 3.2.3):

Як свідчать Аані на рис. 3.2.3 результати післяекспериментального зрізу ЕГ-1 є вищими за всіма критеріями: змістовність висловлювання - на 14,6\%; аргументованість і структурованість висловлювання - на 26,2\%; лексичний Аіапазон і технічне

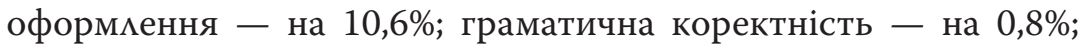
адекватна стилістична забарвленість - на 5,4\%. 


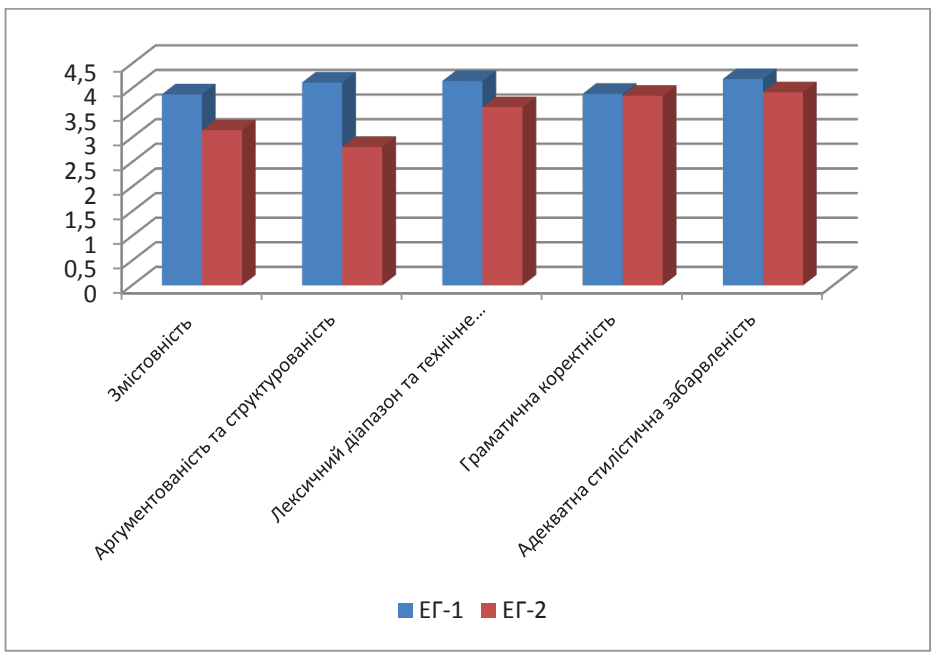

Рисунок 3.2.3 - Зіставмення резумьтатів післяекспериментального зрізу ЕГ-1 та ЕГ-2

Таким чином, зіставцення та аналіз резуцьтатів Аозвоцяє стверАжувати, що результативність студентів покращилася і віАповіАно зріс їх коефіцієнт навченості. Результати експериментацьного навчання ЕГ-1 і ЕГ-2 показують, що застосування Аистанційного навчання на основі систем керування навчанням Аозволяє Аосягти сереАнього коефіцієнту навченості вище за $\mathrm{K}=0,7$. Тим не менше, щоб стверджувати про закономірну (а не випадкову) ефективність нашої моделі, отримані результати повинні бути перевірені статистично.

Аля виконання Ааного завдання нами обрані методи математичної обробки експериментальних Ааних: критерії $U-$ Манна-Уітні та $G$ - критерій знаків.

$U$ - критерій Манна-Уїні використовуємо Аля оцінювання розбіжностей між Авома незв'язаними вибірками за рівнем 
будь-якої ознаки, виміряної кількісно ${ }^{346}$. Критерій $U-$ МаннаУітні дозволить 3'ясувати, чи $є$ статистично значущими віАмінності в показниках коефіцієнту навченості передекспериментальних зрізів й післяекспериментальних зрізів ЕГ-1 та ЕГ-2.

$G$ - критерій знаків використовуємо Аця зіставцення показників, виміряних у Авох різних умовах на оАній вибірці АосліАжуваних А^я того, щоб встановити загацьний напрямок зсуву АосліАжуваної ознаки (чи змінюються показники у бік покращення, піАвищення або піАсилення, чи, навпаки, погіршення, зниження $)^{347}$. Ааний критерій Аозволить з'ясувати, чи сталися статистично значущі позитивні зміни в показниках коефіцієнту навченості передексперименталого та післяекспериментального зрізів у ЕГ-1.

1. Порівнюємо показники коефічієнту навченості передекспериментального зрізу в ЕГ-1 та ЕГ-2 (Критерій $U-$ Манна-Уімні).

$\boldsymbol{H}_{\boldsymbol{0}}$ : статистично значущі віАмінності в показниках коефіцієнту навченості за результатами передекспериментального зрізу між ЕГ-1 та ЕГ-2 не існують.

$\boldsymbol{H}_{\boldsymbol{i}}$ : статистично значущі віАмінності в показниках коефіцієнту навченості за результатами передекспериментального зрізу між ЕГ-1 та ЕГ-2 існують.

Перевіряємо ранжування (Аодаток В5):

$$
\begin{gathered}
\sum R_{\text {заг }}=\sum T_{1}+\sum T_{2}=1378 . \\
\sum R_{i}=\frac{\mathrm{N} \cdot(\mathrm{N}+1)}{2}=\frac{52 \cdot(52+1)}{2}=1378 .
\end{gathered}
$$

Отже, $\Sigma R_{\text {заг }}=\sum R_{i}$.

${ }^{346}$ Євтух М. Б., Аузік Е. В., Іцьїна Т. В. Математичне моделювання в психологічних та соціологічних АосліАженнях: піАручник, 2-ге виА. випр. та Аоповн. Київ: ВиАавничий Аім «КонАор», 2017. С. 34.

${ }^{347}$ Так само. С. 106-109. 
Визначаємо значення $U_{\text {емп }}$ за формулою:

$$
U_{\text {емп }}=n_{1} \times n_{2}+\frac{n_{x}\left(n_{x}+1\right)}{2}-T_{x},
$$

Ае $n_{1}-$ кількість АосліАжуваних у вибірці 1 ;

$n_{2}$ - кількість досліАжуваних у вибірці 2 ;

$T_{x}$ - більша з Авох рангових сум;

$n_{x}$ - кількість досліАжуваних у групі з більшою сумою рангів.

$$
U_{\text {емп }}=26 \cdot 26+\frac{26 \cdot(26+1)}{2}-699,5=327,5 .
$$

Визначаємо критичні значення $U_{\text {кр }}$ за табл. II Аодатка [58, c. 392]:

Отже, $U_{\text {еми }}>U_{\kappa p(\rho=0,05)}$.

Висновок: підтверджена нульова гіпотеза і можна стверАжувати, що статистично значущі віАмінності в показниках коефіцієнту значущості між ЕГ-1 та ЕГ-2 переАекспериментального зрізу не існують.

2. Порівнюемо показники коебічієнту навченості післяексиериментального зрізу ЕГ-1 та ЕГ-2.

$\boldsymbol{H}_{\boldsymbol{0}}$ : статистично значущі віАмінності в показниках коефіцієнту навченості за результатами післяекспериментального зрізу між ЕГ-1 та ЕГ-2 не існують.

$\boldsymbol{H}_{\boldsymbol{1}}$ : статистично значущі віАмінності в показниках коефіцієнту навченості за результатами післяекспериментального зрізу між ЕГ-1 та ЕГ-2 існують.

Перевіряємо ранжування (Аодаток В6):

$$
\begin{gathered}
\sum R_{\text {заг }}=\sum T_{1}+\sum T_{2}=1378 . \\
\sum R_{i}=\frac{\mathrm{N} \cdot(N+1)}{2}=\frac{52 \cdot(52+1)}{2}=1378 .
\end{gathered}
$$

Отже, $\sum R_{\text {заг }}=\sum R_{i}$ 
Визначаємо значення $U_{\text {емп }}$ за формулою:

$$
U_{\text {емп }}=n_{1} \times n_{2}+\frac{n_{x}\left(n_{x}+1\right)}{2}-T_{x}
$$

Ае $n_{1}-$ кількість досліАжуваних у вибірці 1 ;

$n_{2}$ - кількість АосліАжуваних у вибірці 2 ;

$T_{x}$ - більша з Авох рангових сум;

$n_{x}$ - кількість досліджуваних у групі з більшою сумою рангів.

$$
U_{\text {емп }}=26 \cdot 26+\frac{26 \cdot(26+1)}{2}-849,5=177,5 .
$$

Визначаємо критичні значення $U_{\text {кр }}$ за табл. II Аодатка [58, c. 392]:

$$
U_{\text {кр }}=\left\{\begin{array}{l}
247(\text { якщо } \rho \leq 0,05) ; \\
247(\text { якщо } \rho \leq 0,01) .
\end{array}\right.
$$

Отже, $U_{\text {eмп }}<U_{\kappa p(\rho=0,01)}$.

Висновок: віАхимяємо нульову гіпотезу, приймаємо ацьтернативну гіпотезу. Можна стверАжувати, що статистично значущі віАмінності в показниках коефіцієнту навченості за результатами післяекспериментацьного зрізу в ЕГ-1 та ЕГ-2 існують на 1-відсотковому рівні значущості $(\rho=0,01)$.

3. Порівнюемо показники коефічієнту навченості отримані в передекспериментальному та післяекспериментальному зрізах ЕГ-1 (G - критерій знаків).

$\boldsymbol{H}_{\boldsymbol{0}}$ : статистично значущій зсув в показниках коефіцієнту навченості за результатами передекспериментального та післяекспериментального зрізів у ЕГ-1 у бік їх збільшення не існує.

$\boldsymbol{H}_{\boldsymbol{l}}$ : статистично значущій зсув в показниках коефіцієнту навченості за результатами передекспериментального та післяексперимента^ьного зрізів у ЕГ-1 у бік їх збільшення існує. 
ОАразу зазначаємо, що «Аодатній зсув» $є$ типовим зсувом Аля всіх отриманих значень, а це свідчить про наявність змін у «позитивному намрямку» - коефіцієнт навченості збільшився.

ВіАповіАно Ао отриманих Ааних (Аодаток В7), «нетипові» зсуви - віАсутні:

$G_{\text {емп }}=0$ (кількості нетипових зсувів).

За табц. V додатка ${ }^{348}$ визначаємо критичні значення $G_{\text {кр}}$ :

$$
G_{\text {кр }}=\left\{\begin{array}{l}
8(\text { якщо } \rho \leq 0,05) ; \\
6(\text { якщо } \rho \leq 0,01) .
\end{array}\right.
$$

Отже, $G_{\text {емп }}<G_{\text {кр }(\rho=0,01)}$.

Висновок: віАхиляємо нульову гіпотезу, приймаємо альтернативну гіпотезу. Можна стверджувати, що зсув у бік покращення показників коефіцієнту навченості за результатами передекспериментального та післяекспериментального зрізів ЕГ-1 є статистично значущим на 1-відсотковому рівні $(\rho=0,01)$.

Спираючись на отримані Аані, можна зробити висновок, що запропонована нами методика Аистанційного навчання англійського аргументативного письма майбутніх правознавців, яка реалізовувалася на платформі LMS Moodle в умовах керованого навчання із використанням аАміністративних, навчальних та комунікативних інструментів системи $є$ ефективною, аАже сприяє Аосягненню цілей та реалізації завдань англійського аргументативного письма, а саме формуванню необхіАних умінь англійського аргументативного письма.

${ }^{348}$ Євтух М. Б., Аузік Е. В., Іцьїна Т. В. Математичне моделювання в психологічних та соціологічних АосліАженнях: піАручник, 2-ге виА. випр. та Аоповн. Київ: ВиАавничий Аім «Кондор», 2017. С. 399. 


\section{3 Методичні рекомендації щодо організації} Аистанційного навчання ангАійського аргументативного письма майбутніх правознавців

ПровеАене експериментальне навчання за авторською метоАикою, аналіз та інтерпретація його результатів Аозволяють нам сформулювати методичні рекомендації щодо організації навчання англійського аргументативного письма студентів-юристів в умовах дистанційного навчання на платформі електронного навчання Moodle. Методичні рекомендації, засновані на науковому аналізі та практичному АосвіАі його реалізації, націкені допомогти викмадачам у вироблені рішень та їх практичному втіленню піА час Аистанційного навчання англійського аргументативного письма студентів-юристів. Зокрема, метоАичні рекомендації спрямовані на вирішення завдань щодо організації навчальної Аіяльності, її реалізації та оцінки отриманих результатів.

Сформулюємо основні методичні рекомендації щодо організації навчального процесу за Аистанційною формою Аля навчання ангАійського аргументативного письма студентівюристів.

Ефективна організація переАбачає проектування навчання як єАиної системи, функціонування якої повинно забезпечувати отримання певного продукту, який $є$ метою іiі існування. На організаційному етапі процесу дистанційного навчання англійського аргументативного письма повинні бути визначені ${ }^{349}$ :

- цільова аудиторія, її потреби та вихідні характеристики;

- навчальні умови та середовище;

${ }^{349}$ Заярна I.С. Методика Аистанційного навчання англійського аргументативного писемного мовмення майбутніх правознавців: Аис. ... канА. пеА. наук: спец. 13.00.02. Київ, 2019. С. 173. 
- навчальні цікі;

- завдання Аля їх реалізації та терміни виконання;

- принципи навчання;

- зміст навчання англійського аргументативного письма, навчамьні стратегї;

- навчальні матеріали;

- методи навчання та системи доставки;

- технічні засоби віртуацьної системи Moodle Аля реацізації навчальних залач;

- форми та критерії оцінювання.

Аналіз вихідних Ааних (цільова аудиторія слухачів, навчальні умови) $є$ віАправною точкою в процесі проектування навчамьної Аіямьності, а тому відіграє вкрай важливу ромь Аля успішної реалізації проекту Аистанційного навчання англійського аргументативного письма. Зауважимо, що збір необхіАних Ааних може зАійснюватися за Аопомогою анкет, опитування, зрізів, інтерв'ювання.

BiA самого початку варто встановити i надамі враховувати при плануванні вихіАний рівень сформованих у стуАентів умінь ангАійського писемного мов ення та Аогічного мислення, комп'ютерних навичок, умінь та навичок навчатися, працювати самостійно та Аистанційно. Важмиво також визначити ступінь вмотивованості студентів Ао Аистанційного навчання ангАійського аргументативного письма та їх фізичні можАивості Ао зАійснення цієї Аіяльності (наявність засобів електронної комунікації та Аоступ Ао мережі Інтернет).

Особливістю Аистанційного навчання англійського аргументативного письма $\epsilon$ навчальні умови та навчацьне сереАовище, опосередковані комп'ютером. Так, перед початком навчання, варто ознайомити студентів 3 правимами роботи за комп'ютером, Аотримання яких збереже їх зАоров'я та убереже віА можиивих травм чи захворювань. 
Серйозним викликом Аистанційного навчання, який мають враховувати викмаАачі при Аистанційному навчанні англійському аргументативному письму і вкАючити Ао свого плану піАготовки, $\epsilon$ брак міжмюАського спілкування, коми комунікація між учасниками навчацьного процесу опосередкована комп'ютером. ПоАолання психологічного Аискомфорту, пов'язаного з безособистісним характером Аистанційного навчання, можииве шляхом свідомого створення Аружньої навчальної онцайн спільноти. Тобто, викцадачу необхіАно вкАючити соціальний компонент Ао загацьної системи навчання шляхом створення соціальних форумів, на яких студенти можуть обговорювати питання не пов'язані безпосередньо 3 навчанням англійського аргументативного письма, закритих чатів (кише Аля студентів), використання сервісу Обмін повідомленнями Аля підтримки та задоволення індивіАуальних потреб студентів.

ПіА час реалізації авторської методики Аистанційного навчання англійського аргументативного письма студентівюристів рекоменАуємо застосовувати конструктивістський, компетентнісний, жанровий піАходи та спиратися на низку принципів: Аидактичних (посильності, свідомості, активності, наочності), психологічних (принципи мотивації, поетапності формування мовленнєвих умінь та навичок, врахування індивіАуально-психологічних особливостей особистості студента, врахування адаптаційних процесів) та методичних (комунікативності, автентичності, професійної спрямованості навчання, ситуативно-тематичної організації навчання). Ефективність авторської методики залежить також віА технологій навчання, кАючовими були визначені метод кейсів та метод Сократа.

СереА Аоступних на сьогодні онлайн технологій, піА час Аистанційного навчання англійського аргументативного письма перевагу сліА наАавати системам керування навчанням, зокрема, Moodle. ААміністративні, комунікативні та навчальні сервіси 
LMS Moodle, завдяки вбудованим інструментам та закмаАеним принципам, Аозволяють ефективно реалізовувати цілі та завдання навчання англійського аргументативного письма та зАатні забезпечити як індивідуальне, так і спільне навчання. Ао технічних засобів, які варто застосовувати піА час Аистанційного навчання англійського аргументативного письма, належать наступні інструменти LMS Moodle: комунікативні (Форум, Чат, Обмін повідомленнями); навчальні (Урок, Завдання, Тести, Анкети, Опитування, Вікі, Гцосарій, Семінар); адміністративні (Оцінки, Групи, Звіти, Кахендар, Файли).

ВіАповіАно до проведеного АосліАження у піАрозАілі 1.3 цієї монографії, ми можемо надати наступні методичні рекоменАації щодо ефективного використання різноманітних сервісів платформи Moodle 3 урахування особливостей навчання англійського аргументативного письма студентів-юристів:

1. ОАним 3 напрямків використання комунікативних сервісів $є$ обгрунтування правової природи юридичного змістового компоненту. Зокрема, в Форумі чи в Чаті можна обговорити правову природу ситуації, покмадену в основу майбутнього письмового тексту, чи АосліАити найбільш Аискусійні юриАичні питання теми, що вивчається. Студенти також можуть поставити вАасні питання, щоб ініціювати Аискусію.

2. Комунікативні сервіси також сліА застосовувати Аля створення Аружньої навчальної онлайн спільноти. Зокрема, перший Форум може бути присвячений знайомству, інтересам студентів, обговоренню книг чи фільмів/серіалів 3 правової тематики, гучних судових рішень чи знакових поАій на юриАичному ринку (наприклаА, створення юридичних ботів) та ін. Варто також Аозволити студентам створити закритий Чат (Аише Аля студентів) Аля обговорення найбільш цікавих питань. Сервіс Обмін повідомиення варто використовувати Аля особистого спіккування викцадача і студента. 
3. Щоб представити матеріал у цікавій та гнучкій формі, рекомендуємо використовувати технічні можливості сервісу Урок. Зокрема, піА час преАставлення структури письмового тексту, правового контенту, ввеАення Аексичних і граматичних одиниць Ао текстових сторінок можна Аодати гіперпосилання (посилання на веб-сторінки та файли різних форматів), питання Аля самоперевірки.

4. Сервіси Завдання та Тести необхідно використовувати А^я перевірки рівня засвоєного матеріалу, виконаного у будьякому електронному форматі (текстовий Аокумент, презентація PowerPoint, ayAio, відео, інше) $з$ можливістю прокоментувати та оцінити його.

5. Сервіс ГАосарій варто наповнити цексичними одиницями, які повинні бути засвоєні студентами під час навчання. Рекомендуємо забезпечити студентів не мише українськими еквівалентами віАповіАних англійських юридичних термінів, а й надати дефініцію цих понять.

6. ААміністративні сервіси варто використовувати Аля керування навчальним процесом. Зокрема, сервіс Оцінки містить віАомості щодо результатів виконаних робіт студентів; сервіс Звіти сліА використовувати, щоб моніторити успішність студентів піА час вивчення теми; сервіс Календар варто застосовувати Аля повіАомлення студентів про графік провеАення поАій курсу.

ПіА час навчання англійського аргументативного письма засобами Аистанційної освіти варто також враховувати зміну ролей викмадача і студента. Студенти стають самостійними та автономними: вони активно беруть участь у процесі свого в асного навчання, інтегрують, продукують, розширюють свої знання, визначають зручний Аця навчання час, кількість спроб на виконання того чи іншого завдання, вчаться Аумати критично. В свою чергу, роль викладача піА час Аистанційного 
навчання також змінюється: він не пояснює і тим більше не змушує до навчання. Викмадач створює умови, забезпечує студента достатньою Аля виконання завдання кількість матеріалів, він спостерігає за успішність кожного студента зокрема і всіє групи в цілому, анацізує Аані, порівнює результати, сприяє кожному студенту у Аосягненні ним заАовільного рівня сформованості необхінних знань, умінь та навичок, він мотивує і надихає. Викмадач має постійно в процесі навчання тримати

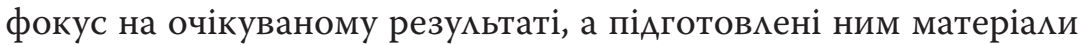
та завдання мають слугувати «провіАниками» Аля студентів на шляху Аосягнення головної мети навчамьної діяльності - сформованості у них навичок та умінь ангмійського аргументативного письма ${ }^{350}$.

У системі віртуацьного навчання Moodle за Аопомогою параметра «Змінити роль» викмадач також має можливість технічно змінити свою роль на роль студента. Це Аозволяє йому поглянути на курс очима своїх учнів. Ааний парламент рекоменАуємо використовувати піА час завантаження навчацьних матеріалів в систему. Він Аозвоцяє викмаАачу перевіряти технічну сторону роботи системи (віА загального вигляду матеріалів на екрані Ао особливостей роботи того чи іншого параметру) i, за потреби, вчасно змінювати налаштування Аля ефективності і зручність роботи всіх їі учасників.

При упроваАженні авторської методики Аистанційного навчання англійського аргументативного письма студентівюристів рекомендуємо орієнтуватися на визначену нами мету формування умінь та навичок вільно та самостійно (одержавши всю необхідну інформацію і не користуючись Аодатковими матеріалами) створювати у віАповіАності Ао встановлених

${ }^{350}$ Заярна I.C. Методичні рекомендації щодо організації е-навчання англійського аргументативного письма майбутніх правознавців. Інноваційна педагогіка. Науковий журнал. Вип. 19. Т. 3. ВиАавничий дім «Гемьветика», 2019. С. 89. 
критеріїв та жанрових зразків юридичні тексти аргументативного писемного мовлення. Ао основних жанрів, які є ефективними ААя Аосягнення поставленої мети, віАносимо Аист-пораАу, меморандум, мист-попередження, позовну заяву, Аист-віАповідь на попереАження.

Важливим аспектом проектування Аистанційного навчання англійського аргументативного письма, що забезпечує Аосягнення постав еної мети $€$ визначення змісту навчання англійського аргументативного письма. ПровеАене АосліАження у піАрозАілі 2.1 цієї роботи Аозволяє сформулювати наступні рекомендації щодо змісту навчання ангАійського аргументативного письма студентів-правників, які сліА враховувати викцаАачу піА час проектування віАповіАної навчальної Аіяльності:

1. Аистанційне навчання англійського аргументативного письма студентів-юристів має обумовлюватися професійно-трудовою сферою спілкування, якій притаманні типові Аля писемного мовцення юриста теми та комунікативні ситуації. Характерними темами спілкування визначаємо різноманітні галузі права (Contract Law, Real Property Law, Company Law, Criminal Law, Family Law, Employment Law, IT Law, etc.). Щодо створення комунікативно-мовленнєвої ситуації піА час англійського аргументативного письма, рекомендуємо враховувати реальні умови, за яких зАійснюється комунікація; стосунки між учасниками комунікаційного процесу; мовленнєві наміри; реалізацію самого акту комунікації, який спонукає Ао мовлення.

2. Ао мовного матеріалу, яким варто оволодіти студентам-правникам, належать мексичні одиниці, граматичні структури, засоби сполучуваності слів і зв'язку речень, фонова мексика. У свою чергу, Ао мовленнєвого матеріацу сліА вкцючити кАіше, формули мовленнєвого етикету, жанрово-композиційні особливості текстів, культурно маркований компонент семантики Аінгвацьних одиниць аргументативного мовлення. 
3. Аیя успішного продукування англійського аргументативного письма студенти повинні оволодіти низкою знань, навичок та умінь. А саме, знаннями юридичного компоненту, функціональних піАтипів аргументативного мовлення, тактик та мовних засобів Аля ефективної реалізації аргументативного мов ення, композиційних особливостей різноманітних жанрів ангАійського аргументативного письма та їх $\Lambda$ інгвосоціокультурних характеристик; граматичними, мексичними, аргументативними та Аінгвосоціокультурними навичками; уміннями аналізувати текст із погляду наявності в ньому аргументативних тактик (обгрунтування, повного або часткового спростування, полеміки), визначати мовні засоби вираження англійського аргументативного письма, композиційні та жанрово-стилістичні особливості текстів, характерні Аля англійського аргументативного письма, віАбирати, планувати й організовувати інформацію в письмовому тексті, прогнозувати комунікативну Аоцільність мовних засобів віАповіАно Ао жанру тексту, використовувати мовні засоби та аргументативні тактики, будувати свою мовценнєву повеАінку віАповіАно Ао соціокультурної специфіки англійського аргументативного письма, продукувати завершені письмові тексти англійського аргументативного письма, аргументуючи власну точку зору за Аопомогою віАповіАних мовних засобів, Аобирати найбільш характерні Аһя юриАичної спільноти засоби i способи Аосягнення комунікативних цілей та реалізації комунікативних стратегій.

ПіА час моделювання змісту Аистанційного навчання англійського аргументативного письма вважаємо Аоцільним враховувати преАметні, могічні та мовні труАнощів, віАповіАно Ао яких та з урахуванням встановлених у піАрозАілі 2.2. принципів та критеріїв, і варто зАійснювати добір текстового, мовного та мовценнєвого матеріалів. 
Реалізацію змісту навчання варто зАійснювати у віАповіАності до визначених у піАрозАілі 2.3 цієї монографії етапів шляхом виконання піАсистеми вправ та завдань різних видів та типів. Так, на предметно-орієнтаційному етапі рекоменАуємо використовувати завАання на формування преАметних знань в галузі права, а також некомунікативні та умовно-комунікативні вправи на формування Аексичних та граматичних навичок; Аля аргументаційно-тренувацьного етапу варто використовувати вправи на формулювання правового питання (тези), визначення форми та способу аргументації, визначення структурних частин аргументації в межах аргументативного тексту та завдання на формування аргументативних навичок; на Аотекстово-аналітичному етапі сліА виконувати вправи на визначення структурно-композиційних частин та могіки викцаАу композиції визначених жанрів англійського аргументативного письма, на формування мовних навичок Аля продукування визначених жанрів; Аля текстово-продуктивного етапу ефективними будуть завдання на продукування та перевірку текстово-продуктивних умінь англійського аргументативного письма.

Важливу роль піА час Аистанційного навчання англійського аргументативного письма віАіграє оцінювання навчальної Аіяльності студента. ВіАповіАно Ао провеАеного АосліАження у піАрозділі 1.3, рекомендуємо викмадачам застосовувати компетентнісний піАхіА Ао оцінювання навча^ьних Аосягнень студентів, а саме застосовувати формуюче оцінювання та піАсумкову оцінку. Формуюче оцінювання сліА використовувати піА час усього процесу навчання заАля того, щоб студенти розуміли свої сильні та слабкі сторони. Варто, щоб оцінювання було постійним і конкретним, у формі коментарів, без виставмення балів, Аостатньо Аетальними, щоб студент міг усвідомити свої сицьні та слабкі сторони, оцінити свою роботу, знайти 
і застосувати необхідні стандарти змісту, формату, стилю. Ефективним методом може бути «сократівська бесіда». На відміні віА формуючого оцінювання, підсумкове оцінювання сліА застосовувати Аця перевірки рівня сформованості віАповіАних вмінь та навичок в кінці кожного етапу. Зауважимо, що оцінювання, згіАно $з$ компетентнісним піАходом, повинно бути автентичним, тобто враховувати завдання, контекст і критерії оцінювання. Отримати позитивну оцінку студент зможе мише за умови успішного виконання піАсумкового автентичного завдання. Оцінювання піАсумкового завдання сліА зАійснювати віАповіАно Ао визначених нами критеріїв:

- змістовність висловлювання;

- аргументованість та структурованість висловлювання;

- $\quad$ ексичний Аіапазон та технічне оформлення;

- граматична коректність;

- адекватна стилістична забарвленість (регістр і формат висловцювання).

Стандарти (норми) оцінювання підсумкового завдання були визначені нами у піАрозділі 3.1 у віАповіАності до зазначених вище критеріїв.

ПіА час проектування Аистанційного навчання англійського аргументативного письма важливо визначити оптимальні часові терміни виконання поставлених завдань. ВіАповіАно Ао авторської моделі рекомендований термін проходження Аистанційного курсу - 6 тижнів (60 позаауАиторних годин) з орієнтовним навантаженням 1-1,5 академічні години щоАня. Час, рекомендований ААя проходження кожного модуля, - 12 академічних годин. Оскільки модель Аистанційного навчання англійського аргументативного письма має цикмічний характер, кількість модулів може варіюватися у відповіАності до кількості визначених жанрів англійського аргументативного письма. 
Отже, піАсумовуючи, зазначимо що ефективна реалізація авторської методики Аистанційного навчання англійського аргументативного письма студентів-юристів безпосереАньо залежить віА врахування методичних рекомендацій, спрямованих на запобігання потенційних труднощів піА час планування, піАготовки та зАійснення навчання ангмійського аргументативного письма студентів-юристів Аистанційними засобами в системі віртуацьного навчання Moodle. 


\section{ПІС $А$ МОВА}

Проведене Аослідження присвячене методиці Аистанційного навчання англійського аргументативного письма майбутніх правознавців. Реалізація поставлених цілей і завдань знайшла своє відображення у проведенні Аіахронного аналізу проблеми Аистанційного навчання англійського аргументатвиного письма студентів-юристів; визначенні жанрів англійського аргументативного письма юристів та їх Аінгвістичних особливостей; АосліАженні теоретико-методичних аспектів Аистанційного навчання ангАійського аргументатвиного письма студентів-юристів. У монографічній роботі сформульовано цілі та зміст Аистанційного навчання англійського аргументатвиного письма, визначено критерії віАбору текстового та мовного матеріалів та на їх основі зАійснено відбір текстів, Аексичних оАиниць та граматичних структур; теоретично обгрунтовано та розроблено піАсистему вправ та завдань, а також створено методичну модель організації процесу Аистанційного навчання англійського аргументатвиного письма майбутніх правознавців; описано процес планування, підготовки та проведення експерименту; сформульовано критерії та норми оцінки результатів навчання, спрямованого на формування умінь англійського аргументативного письма; експериментально перевірено ефективність авторської методики та розроблено методичні рекомендації щодо Аистанційного навчання англійського аргументатвиного письма майбутніх правознавців.

У результаті наукових пошуків ми Аійшли наступних висновків:

1. З'ясовано, що аргументативне мовлення $є$ невіА'ємним компонентом іншомовної комунікативної компетентності 
майбутніх правознавців, яке сліА розуміти як комунікативний процес, націлений на вираження своїх Аумок 3 метою переконання в істинності чи хибності якогось положення за Аопомогою аргументів, побудованих віАповіАно Ао правих семантики, синтактики і прагматики, а також з урахуванням правової сфери застосування. Кінцевим продуктом ангАійського аргументативного письма визначено аргументативний текст в його комунікативних різновиАах, які можуть бути Аиференційовані як типи текстів: текст-обгрунтування, текст-повне спростування та текст-часткове спростування. Аоведено, що навчання англійського аргументативного письма майбутніх юристів має зАійснюватися віАповіАно до ситуацій спілкування, притаманних існуючій юридичній практиці. Аля ефективного навчання ангмійського аргументативного письма виокреммені наступні жанри писемного мовцення у межах юридичного Аискурсу: a letter of advice - $и$ ист-порада; a memorandum меморандум; a letter before action - $и$ ист-попередження; a legal complaint - позовна заява; reply to a demand letter - кист-віАповіАь); а також вивчені їх композиційні, мовні та аргументаційні характеристики.

2. Обгрунтовано, що Аистанційна форма $€$ ефективною Аля реалізації навчання англійського аргументативного письма в юридичних $3 \mathrm{BO}$ завАяки притаманним їй специфічним якісним властивостям: врахування потреб і можливостей майбутніх правознавців піА час навчального процесу; модульність побудови навчальних програм; зміна ролі виклаАача; спеціальні форми контролю якості навчальних Аосягнень; використання базових і спеціалізованих комунікативних технологій піАтримки взаємодії суб'єктів процесу навчання; використання спеціалізованих засобів навчання та форм організації навчальної Аіяльності. Встановлено, що Аистанційна форма навчання англійського аргументативного письма 
характеризується плановою системною Аіяльність, яка відображає всі компоненти навчального процесу; віАокремленістю у просторі і часі студента і викцадача, а також студентів між собою; використанням різноманітних ресурсів і новітніх технічних засобів навчання; наявністю спеціальних методичних, комунікаційних, організаційних та аАміністративних заходів. Визначено, що сереА Аоступних на сьогодні онлайн технологій, піА час Аистанційного навчання англійського аргументатвиного письма перевагу слід надавати системам керування навчанням, зокрема, LMS Moodle. Проаналізовані можиивості навчальних, аАміністративних та комунікативних інструментів LMS Moodle як засобів Аистанційного навчання англійського аргументативного письма.

Встановлено, що Аистанційне навчання англійського аргументатвиного письма сліА зАійснювати 3 позицій конструктивістського, компетентнісного та жанрового піАходів, які забезпечують ефективну організацію навчального процесу, спрямованого на формування умінь та навичок англійського аргументативного письма в умовах Аистанційної освіти. КАючовими у процесі Аистанційного навчання англійського аргументатвиного письма визначені такі дидактичні (посицьності, свідомості, активності, наочності), психологічні (принципи мотивації, поетапності формування мовленнєвих умінь та навичок, врахування індивіАуально-психологічних особливостей особистості студента, врахування аАаптаційних процесів) та методичні (комунікативності, автентичності, професійної спрямованості навчання, ситуативно-тематичної організації навчання) принципи. Основними технологіями навчання англійського аргументативного письма визначені метоА кейсів, заснований на вирішенні конкретних проблемних ситуацій, та метод Сократа, який імітує кооперативний аргументований діалогу між індивідуумами та має на меті стимулювати критичне мислення учасників Аискусії. 
3. Визначено, що метою навчання англійського аргументативного письма майбутніх правознавців $€$ формування навичок та умінь вільно та самостійно (одержавши всю необхідну інформацію і не користуючись Аодатковими матеріалами) створювати у віАповіАності до встановлених критеріїв та жанрових зразків юриАичні тексти аргументативного писемного мовцення. Уточнено зміст навчання англійського аргументативного письма та обгрунтовано, що навчання англійського аргументативного письма студентів-юристів обумовлюється професійно-трудовою сферою спілкування, якій притаманні типові Аһя писемного мовлення юриста теми та комунікативні ситуації. Мовний та мовленнєвий навчахьний матеріали, яким необхіАно оволодіти майбутнім юристам піА час навчання англійського аргументативного письма, вкмючає мексичні одиниці, граматичні структури, засоби сполучуваності слів і зв'язку речень, фонову мексику, кміше, формули мовленнєвого етикету, жанрово-композиційні особливості текстів, культурно маркований компонент семантики Аінгвацьних одиниць аргументативного мовцення. Встановцено, що зміст навчання англійського аргументативного письма охоплює знання юриАичного компоненту, функціонацьних піАтипів аргументативного мовлення, тактик та мовних засобів Аця ефективної реалізації аргументативного мовАення, композиційних особливостей різноманітних жанрів англійського аргументативного письма та їх мінгвосоціокультурних характеристик; граматичні, Аексичні, аргументативні та мінгвосоціокультурні навички; уміння аналізувати текст із погляду наявності в ньому аргументативних тактик, визначати та використовувати мовні засоби вираження англійського аргументативного письма, композиційні та жанрово-стилістичні особливості текстів, уміння відбирати, планувати й організовувати інформацію в письмовому тексті, уміння продукувати завершені письмові тексти англійського аргументативного 
письма, аргументуючи вмасну точку зору за допомогою віАповіАних мовних засобів, уміння добирати найбільш характерні ААя юридичної спільноти засоби і способи Аосягнення комунікативних цілей та реалізації комунікативних стратегій.

4. 3’ясовано, що добір текстового, мексичного і граматичного матеріалу сліА зАійснювати, Аотримуючись принципів необхідності та вичерпності, посильності та Аоступності, вживаності та поширеності, прагматичності та професійної ефективності, автентичності. Аобір навчального матеріалу зАійснюємо з урахуванням могічних, преАметних та мовних труднощів. ОАиницями Аобору Аля продукування ангАійського аргументативного письма визначені кексичні одиниці, граматичні структури та цілісний текст, що віАбираються віАповіАно Ао встанов ених критеріїв: Аля текстового матеріалу - критеріїв професійної спрямованості, комунікативної цінності, автентичності, актуацьності та посицьності; Аля граматичного матеріацу - критеріїв стабільності, зразковості та стилістичної унормованості; Аля мексичного матеріалу 一 критеріїв комунікативної цінності, професійної спрямованості, словотвірної зАатності та тематичності.

5. Розроблено підсистему вправ та завдань Аля Аистанційного навчання ангАійського аргументатвиного письма, яку сліА розуміти як сукупність груп вправ та завдань різних виАів та типів, які зАатні забезпечити максимацьний рівень оволоАіння уміннями та навичками англійського аргументативного письма піА час Аистанційного навчання за умов їх поетапного виконання. Обгрунтовано, що Аистанційне навчання англійського аргументатвиного письма сліА зАійснювати у чотири етапи: підготовчий етап спрямований на формування мовленнєвих навичок у продукуванні ангмійського аргументативного письма в межах віАповіАного жанру та на подолання мовних та преАметних труднощів; на анацітичному етапі ставимо за мету 
проаналізувати готові тексти Аля визначення композиційних та жанрово-стилістичних особливостей таких жанрів у межах юриАичного Аискурсу як мист-пораАа, мист-попереАження, мист-віАповідь на попереАження, меморандум, позовна заява; тренувальний етап націлений на Аосягнення таких цілей як формулювання тези, аргументів та висновку, а також подолання могічних труднощів; цілями текстово-продукувального етапу визначаємо удосконалення аргументаційних умінь та формування текстово-продукувальних умінь.

Створено модель Аистанційне навчання англійського аргументатвиного письма, яка реалізується в межах навчальної Аисципліни «Іноземна мова (англійська)» піА час II семестру 1-го року навчання Аля студентів ОР «Бакалавр» спеціальності 081 «Право» упродовж 6 тижнів (60 позааудиторних гоАин). Модель Аистанційне навчання ангмійського аргументатвиного письма має модумьний характер. Кожен модумь присвячений навчанню окремого жанру ААПМ, охоплює 12 позааудиторних академічних годин та реалізується у чотири етапи. На піАготовчий етап виАілено 2 години, на аналітичний та тренувальний по 3 годин кожен, текстово-продукувальний передбачає 4 академічні години.

У процесі експерименту було Аоведено гіпотезу: висока ефективність Аистанційного навчання англійського аргументативного письма Аосягається за таких умов: організація навчання зАійснюється на засадах конструктивістського, компетентнісного та жанрового піАходів, а також у віАповіАності до визначених нами Аидактичних, психологічних та метоАичних принципів; використання методу Сократа та кейс-методу; організація навчання на основі таких жанрів англійського аргументативного письма як мист-пораАа, $и$ ист-попереАження, мист-відповідь на попередження, меморандум, позовна заява; використання розробценої нами підсистеми вправ і завдань; 
використання аАміністративних, навчальних та комунікативних інструментів платформи Moodle; застосування авторської моделі методики Аистанційного навчання англійського аргументативного письма.

6. Експеримент тривав 64 академічних години і скмаАався з трьох етапів - передекспериментального зрізу, експериментального навчання та післяекспериментального зрізу. В експериментальному навчанні взяли участь 52 студента (ЕГ $1-26$ осіб, ЕГ $2-26$ осіб) І курсу юридичного факультету Київського національного університету імені Тараса Шевченка, 3 них 26 студентів (ЕГ-1) навчалися Аистанційно, на основі авторської моделі в умовах системи керування навчанням LMS Moodle, режим Аоступу: https://dl.knu.ua/course/view. php?id=9264. 26 студентів ЕГ-2 займалися також Аистанційно в умовах некерованого навчання (навчальний матеріал доставАялся за Аопомогою технологій віАкритого Аоступу). Визначено основні критерії оцінювання англійського аргументативного письма: змістовність висловлювання, аргументованість та структурованість висловлювання, Аексичний Аіапазон та технічне оформлення, граматична коректність, адекватна стилістична забарвленість (регістр і формат висловлювання). У ході експерименту встановлено, що модель Аистанційного навчання англійського аргументативного письма студентів-юристів $є$ ефективною, аАже сприяє Аосягненню цілей та реалізації завдань англійського аргументативного письма, а саме формуванню необхіАних умінь англійського аргументативного письма, що підтверАжено за допомогою математичної обробки експериментальних даних (критерії U - Манна-Уїні та G - критерій знаків).

За результатами експериментального навчання розроблені методичні рекомендації, спрямовані на запобігання потенційних труднощів піА час планування, піАготовки та зАійснення 
навчання англійського аргументативного письма студентівюристів Аистанційними засобами в системі віртуального навчання Moodle.

Проведене Аослідження не вичерпує усіх аспектів АосліАжуваної проблеми. Перспективу подальших наукових розвіАок вбачаємо в розробленні методики Аистанційного навчання усного аргументативного мовлення на матеріалі інших стилів та жанрів мовлення. 


\section{СПИСОК ВИКОРИСТАНИХ АЖЕРЕА}

1. Алекси Р. Юридическая аргументация как рациональный Аискурс / пер. с нем. М. В. Антонова // Российский ежегоАник права. 2008. № 1.

2. Английский Аля юристов - English: We Study Law: учеб. пособие Аля студентов вузов, обучающихся по специальности 021100 «Юриспруденция» / авт.-сост. Немировская Э.А. и Ар. 2-е изА., испр. Москва: Аого Камерон; ИзА-во Омега- $\Lambda, 2006.376$ с.

3. Андреев А.А. Аидактические основы Аистанционного обучения в высших учебных завеАениях: Аис. Аокт. пеА. наук: 13.00.08. Москва: РАО, 1999. 289 с.

4. Андреев А. А. Солдаткин В. И. Аистанционное обучение: сущность, технология, организация. Москва: Издательство МЭСИ, 1999. 196 с.

5. Андреев А. В., Андреева С. В., Аоценко И. Б. Практика электронного обучения с использованием Moodle. Таганрог: ИзА-во ТТИ ЮФУ, 2008. 146 с.

6. Андрєєв А. А. Введення в Аистанційне навчання: навчально-методичний посібник. Москва: ВУ, 1997.

7. Андрущенко В. П., КуАін А. П. Реалізація системи безперервної освіти в Національному педагогічному університеті імені М. П. Арагоманова через Аистанційну форму навчання // Вісн. АкаА. Аистанц. освіти. 2003. № 1. С. 49-50.

8. Антонова И.Б. Методическая эффективность использования письма как средства обучения аргументированию в неязыковом вузе: английский язык: автореф. Аис. ... канА. пеА. наук: 13.00.02; Моск. Аингвистический ун-т. Москва, 1994. 21 с. 
9. Антонова И.Б. Методическая эффективность использования письма как средства обучения аргументированию в неязыковом вузе: английский язык: Аис. ... канА. пеА. наук: 13.00.02; Моск. мингвистический ун-т. Москва, 1994. 254 с.

10. Асоянц П. Г., Чекаль Г. С., Сердюков П. І. Основи метоАики створення та застосування комп'ютерних програм у навчанні іноземних мов. Київ: КАПІІМ, 2002. 108 с.

11. Баранов А.Н. Аингвистическая теория аргументации (когнитивный поАхоА): автореф. Аис. ... А-ра филол. наук: 10.02.01. Москва: 1990.48 с.

12. Баранова Е. А. Методика обучения аргументированному письменному высказыванию: на материале французского языка, языковой факультет: автореф. Аис. ... канА. пеА. наук: 13.00.02; Моск. гос. гуманитар. ун-т им. М. А. Шолохова. Орел, 2013. 23 с.

13. Батурина Ю. В. Формирование аргументативных стратегий у магистрантов-психологов с использованием сетевых компьютерных технологий: на материале английского языка: Аис. ... канА. пеА. наук: 13.00.02; Санкт-Петербургский гос. ун-т. Санкт-Петербург, 2015. 275 с.

14. Бачинська I. А. Формування англомовної мінгвосоціокультурної компетенції учнів старшої школи: Аис. ... канА. пеА. наук: 13.00.02. Херсон, 2015. 217 с.

15. Белова А.А. Аингвистические аспекты аргументации. Киев: Астрея, 1997. 311 с.

16. Бережна I. В. Методика навчання майбутніх філологів англійського писемного мовлення 3 використанням мовного портфеля: Аис. ... канА. пеА. наук: 13.00.02. Запоріжжя, 2012. 341 с.

17. Бескорса О.С. Система Moodle як засіб організації змішаного навчання практичної фонетики німецької мови // Інформаційні технології і засоби навчання. 2017. Том 62. № 6. URL: file:///C:/Users/\%D0\%9E\%D0\%BB\%D0\%B5\%D0\%B3/ Downloads/1832-8577-1-PB\%20(1).pdf. 
18. Беспацько В. П. Опыт разработки и использования критериев качества усвоения знаний // Советская педагогика. 1968. № 4. С. 52-69.

19. Бех П. О., Биркун $\Lambda$. В. Концепція викмадання іноземних мов в Україні. Іноземні мови. 1996. № 2. С. 3-8.

20. Бикулова Г. Р. Методика Аистанционного формирования коммуникативной компетенции студентов естественных факультетов университета: на материале английского языка 13.00.02. Санкт-Петербург, 2008. 239 с.

21. Биков В. Ю. Аистанційна навчання // ЕнциклопеАія освіти України / АкаА. пеА. наук України; головний реА. В. Г. Кремень. Київ: Юрінком Інтер, 2008. С. 191-193.

22. Биков В. Ю., Гриценчук О. О., Жук Ю. О. Аистанційне навчання в країнах Європи та США і перспективи Аля України // Інформаційне забезпечення навчально-виховного процесу: інноваційні засоби технології: монографія / Академія педагогічних наук України, Інститут засобів навчання. Київ: Атіка, 2005. 252 c.

23. Биков В. Ю., Кухаренко В. М., Сиротенко Н. Г., Рибацко О. В., Богачков Ю. М. Технологія створення Аистанційного курсу: навчальний посібник / за реА. В. Ю. Бикова, В. М. Кухаренка. Київ: Міленіум, 2008. 324 с.

24. Биков В. Ю. Моделі організаційних систем відкритої освіти: монографія. Київ: Атіка, 2008. 684 с.

25. Бим И. А. Методика обучения иностранным языкам как наука и проблема школьных учебников: опыт системно-структурного описания. Москва: Русский язык, 1977. 288 с.

26. Бігич О. Б. Електронний кейс як засіб формування у майбутніх менеАжерів туризму міжкумьтурної компетентності. Іноземні мови. № 1 (89). 2017. C. 17-22. URL: file://C:/Users/ \%D0\%9E\%D0\%BB\%D0\%B5\%D0\%B3/Downloads/122633-2612601-SM.pdf 
27. Бігич О. Б. РізновиАи професійно орієнтованого підходу Ао навчання іноземної мови як непрофільної Аисципліни. II Міжнародна науково-практична конференція «Комунікація у сучасному соціумі». 8 червня 2018. URL: https://conferences.lnu.edu.ua/index.php/communicatios / communication-2018/paper/view/24

28. Білоус С. В. Навчання майбутніх філологів англійського усного монологічного персуазивного мовлення: автореф. Аис. ... канА. пеА. наук: 13.00.02; КНУ імені Т. Шевченка. Київ, 2017. 22 c.

29. Білоус С. В. Навчання майбутніх філологів англійського усного монологічного персуазивного мовлення: Аис. ... канА. пеА. наук: 13.00.02; КНУ імені Т. Шевченка. Київ, 2017. 228 с.

30. Бірецька $\Lambda$. С. Критерії віАбору навчального матеріалу Аля формування англомовної мексичної компетентності майбутніх Аікарів у процесі професійно орієнтованого читання // Науковий вісник кафеАри Юнеско КНАУ. Серія Філомогія. Педагогіка. Психологія, 2013. Випуск 27. С. 232-238.

31. Боднар А. Я., Макаренко Н. Г. Шияхи формування пізнавацьного інтересу особистості в процесі професійного самовизначення // Наукові записки. ПеАагогічні, психологічні науки та соціацьна робота. Том 162. С. 33.

32. Болюбаш Н. М. Організаційно-методичні аспекти навчання на базі інформаційного середовища Moodle // Інформаційні технології і засоби навчання. 2013. № 1 (33). URL: file:///C:/Users/\%D0\%9E\%D0\%BB\%D0\%B5\%D0\%B3/ Downloads/761-2611-1-PB\%20(1).pdf.

33. Бондар $\Lambda$. В. Вимоги до навчального матеріалу Аля формування компетентності у франкомовному говорінні у майбутніх фахівців з інформаційних технологій // Наукові записки Націонацьного педагогічного університету ім. М. П. Арагоманова. Педагогічні та історичні науки. Київ, 2013. Вип. 112. С. 22-29. 
34. Бондарев М. Г. Формирование мингвистической компетенции в процессе обучения профессионацьно ориентированному чтению с помощью компьютерной программы // Известия Российского государственного пеАагогического университета им. А. И. Герцена. 2008. № 82 (2). С. 12-18.

35. Бутенкова Е. В. Интеграция очной и Аистанционной форм обучения иностранному языку в старших классах общеобразовательной школы: филологический профимь, на материале английского языка: Аис. ... канА. пеА. наук: 13.00.02. Москва, 2007. $270 \mathrm{c}$.

36. Бучинська О. В. Психологія кольору як метод якісного маркетинг // Вісник ОНУ імені I. І. Мечникова. 2015. Т. 20. Вип. 1/1. С. 76-80.

37. Вавіліна С. Г. Принципи і критерії Аобору текстів Аля навчання майбутніх журналістів професійно орієнтованого читання // Вісник КНАУ. Серія: Педагогіка та психологія. 2012. Випуск 21. С. 109-118.

38. Вакалюк Т. А. ПіАготовка майбутніх учителів інформа-

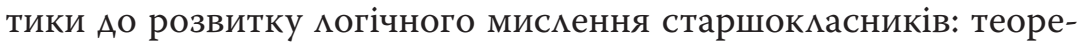
тико-методологічний аспект: монографія. Житомир: ВиА-во ЖАУ імені І. Франка, 2013. 236 с.

39. Вартофский М. Модели. Репрезентация и научное понимание: пер. с англ. Москва: «Прогресс», 1988. 508 с.

40. Васицьченко А. В., Шевченко В. А. Аистанційне навчання: науково-методичне забезпечення; інформаційний простір навчального закладу. Харків: Основа, 2009. 208 с.

41. Вишнівський В. В., Гніденко М. П., ГайАур Г. І., ІАьїн О. О. Організація Аистанційного навчання. Створення електронних навчальних курсів та електронних тестів: навчальний посібник. Київ: АУТ, 2014. 140 с.

42. Влодарчик Р. А. Образно-логическое мышление как фактор развития интемлектуальной сферы субъекта: Аис. ... канА. псих. наук: 19.00.01. Красноярск, 2008. 208 с. 
43. Выготский $\Lambda$. С. Мышление и речь: психологические исследования. Москва: ГСЭИ, 1934. 324 с.

44. Гаврилова А. Н. Формирование письменно речевой аргументативной компетенции у студентов гуманитарных специальностей (английский язык): Аис. ... канА. пеА. наук: 13.00.02; Санкт-Петерб. гос. ун-т. Санкт-Петербург, 2011. 277 с.

45. Гаврілова $\Lambda$., Катасонова Ю. Теоретичні аспекти впроваАження Аистанційного навчання в Україні // Освіто- оогічний Аискурс. 2017. № 1-2 (16-17). С. 168-182.

46. Гальскова Н. А., Гез Н. И. Теория обучения иностранным языкам. АингводиАактика и методика: учеб. пособие Аця стуА. мингв. ун-тов и фак. ин. яз. высш. пеА. учеб. завеАений. 3-е изА., стер. Москва: ИзАательский центр «Академия», 2006. 336 с.

47. Герасименко I. В., Садовий А. І., Білан Н. С. Використання системи Аистанційного навчання на базі Moodle А^я доуніверситетської підготовки // I Всеукраїнська науково-практична конференція «Moodle Moot Ukraine 2013. Теорія і практика використання системи управління навчанням Moodle». (м. Київ, 30-31 травня 2013 р.): тези доповіАей. Київ: КНУБА, 2013.

48. Герасименко I. В. Методика використання технологій Аистанційного навчання в піАготовці бакалаврів комп'ютерних наук: Аис. ... канА. пеА. наук: 13.00.10; Черкас. Аерж. тех. ун-т. Черкаси, 2014. 302 с.

49. Герасименко I. В. Створення навчального курсу в системі електронного навчання на базі Moodle // Педагогічний альманах: зб. наук. пр. / редкол.: В. В. Кузьменко (голова) та ін. Херсон: КВНЗ «Херсонська академія неперервної освіти», 2012. Випуск 16. С. 109-115.

50. ГАухов В. П., Ковшиков В. А. Психолингвистика. Теория речевой Аеятельности. Москва: АСТ, 2007. 223 с.

51. Горюнова Е. С. Критерии отбора текстов Аля обучения студентов неязыковых вузов иноязычному профессио- 
нально ориентированному чтению // Вестник ТГПУ. 2011. Выпуск 2 (104). С. 60-64.

52. Гуров Е. А. Аистанційна освіта як психолого-педагогічна проблема // Шияхи реформування заочної (Аистанційної) вищої освіти: матеріали Всеукр. наук.-метод. конф., 11-13 жовт. 2000 р. / Укр. акаА. Арукарства. Київ; Аьвів, 2000. С. 48-49.

53. Аамирчари Э. Р. Развитие профессионально-логического мышиения у стуАентов экономических специальностей с помощью коммуникативно-мыслительной технологии погружения в профессию: Аис. ... канА. псих. наук: 19.00.07. Ростов-наАону, 2005. 195 с.

54. Аацюк В. В. Обучение студентов восточного факультета аргументативным стратегиям англоязычного Аелового Аискурса: Аисс. канА. пеА. наук: 13.00.02; Санкт-Петербургский гос. ун-т. Санкт-Петербург, 2016. 233 с.

55. Аілова англійська мова Аля юристів: навч. посіб. / $\Lambda$. В. Боровецька, $\Lambda$. Т. Жукова, Н. М. Сініцина та ін. К.: КНЕУ, 2006. 276 c.

56. Аистанційне навчання: психологічні засади: монографія / М. $\Lambda$. Смульсон, Ю. І. Машбиць, М. І. Жамдак та ін.; за ред. М. $\Lambda$. Смульсон. КіровограА: Імекс- $\Lambda$ ТА, 2012. 240 с.

57. Аобровольська С. В. Психолого-педагогічні аспекти Аистанційного навчання як засіб модернізації сучасного процесу освіти // Упр. шк. 2004. № 3. С 27-28.

58. Ароздова І.П. Критерії Аобору текстів Аця навчання професійного мовлення студентів нефілологічного профілю у ВНЗ // Викмадання мов у вищих навчальних закладах освіти. 2010. Випуск 16. С. 69-76.

59. Аружченко Т. П. Методика Аиференційованого навчання ангАійського усного монологічного мовлення майбутніх юристів: Аис. ... канА. пеА. наук: спец. 13.00.02. Київ, 2018. 269 c. 
60. Аудаш T. I. Правова аргументація: стан та перспективи АосліАження // Вісник Аьвівського університету. 2016. № 62. Серія юридична. С. 3-13.

61. Еремерен Ф. Х. Речевые акты в аргументативных Аискуссиях: теоретическая модель анализа дискуссии, направленной на разрешение конфмикта мнений. Санкт-Петербург: Нотабене, 1994. 239 c.

62. Євтух М. Б., Аузік Е. В., І^ьїна Т. В. Математичне модеюювання в психологічних та соціологічних Аослідженнях: піАручник, 2-ге виА. випр. та Аоповн. Київ: ВиАавничий Аім «Кондор», 2017. 428 с.

63. Жевакіна Н.ЧВ. Ефективність Аистанційних технологій навчання // Освіта Аонбасу. 2004. № 2. С. 73-78.

64. Жовнич О. В., Фрейман Г. О. Методика навчання професійно орієнтованого англомовного писемного спілкування майбутніх журналістів засобами блог-технологій: Аис. ... канА. пеА. наук: спец. 13.00.02. Тернопіль, 2018. 303 с.

65. Заболотська О.О. Актуальні проблеми методики викмадання англійської мови. URL: http://ekhsuir.kspu.edu/ bitstream/123456789/1195/1/_1_doc\%20\%282\%29.pdf.

66. Загальна теорія права: піАручник / за заг. реА. М. І. Козюбри. Київ: Ваіте, 2015. 392 с.

67. Загальноєвропейські Рекомендації 3 мовної освіти: вивчення, викмадання, оцінювання / Науковий редактор українського видання доктор пеА. наук, проф. С. Ю. Ніколаєва. Київ: Аенвіт, 2003. 273 с.

68. Заярна I. C. Аеякі методичні аспекти формування умінь англійського аргументативного письма майбутніх правознавців за умов е-навчання. Vector of modern pedagogical and psychological science in Ukraine and EU countries : Collective monograph. Riga : Izdevnieciba "Baltija Publishing", 2020. P. 1. P. 270-286. DOI https://doi.org/10.30525/978-9934-588-37-2.1.16 
69. Заярна I. Аеякі особливості застосування методу кейсів піА час навчання студентів-юристів англійському аргументативному письму. Розвиток сучасної освіти і науки: результати, проблеми, перспективи. Том VII: ІАентичність і свобода в освіті та науці. Ред.: Ян Гжесяк, Іван Зимомря, Василь ІАьницький. Конін - Ужгород - Бєльско-Бяла. Київ: Посвіт, 2019. С. 82-84.

70. Заярна I. С. Аистанційне навчання англійського аргументативного письма студентів-правників як преАмет методичного АосліАження. Освіта Аля XXI століття: викцики, проблеми, перспективи: матеріали I міжнародної науково-практичної конференції (29-30 жовтня 2019 року, м. Суми). Суми: ВиА-во СумАПУ імені А. С. Макаренка, 2019. Том 2. С. 5-8.

71. Заярна I. С. Аистанційний курс English Reasoning Writing for Law Students. URL: https://dl.knu.ua/course/view.php?id=9264.

72. Заярна I. C. Етапи навчання англійського аргументативного письма майбутніх правознавців. Актуальні питання розвитку юриАичної науки та практики: матеріали Міжнародної науково-практичної конференції (15 мистопада 2019 року). За заг. реА. А.ю.н., проф. І. С. Гриценка, к.ю.н. І. С. Сахарук. К., 2019. С. 578-580.

73. Заярна I. С. Застосування жанрового піАходу Ао навчання англійського аргументованого писемного мовлення студентів юриАичного профі^ю. Іншомовна піАготовка працівників правоохоронних органів і сектору безпеки: матеріали III Міжнародної науково-практичної конференції (27 березня 2019 року). Київ: Національна академія прокуратури України, 2019. С. 60-62.

74. Заярна I. С. Зміст навчання англійського аргументативного писемного мовмення майбутніх правників // Неперервна професійна освіта: теорія і практика // Науково-методичний журнам. 2017. Випуск 1-2. С. 81-87.

75. Заярна I. С. Методика Аистанційного навчання ангАійського аргументативного писемного мовлення майбутніх 
правознавців: Аис. ... канА. пеА. наук: спец. 13.00.02. Київ, 2019. 228 c.

76. Заярна I. С. Методичні рекомендації щодо організації е-навчання ангАійського аргументативного письма майбутніх правознавців. Інноваційна педагогіка. Науковий журнал. Вип. 19. Т. 3. Видавничий дім «Гельветика», 2019. С. 87-91.

77. Заярна I. С. Навчання англійського аргументативного писемного мовлення майбутніх правознавців: психолінгвістичний аспект // Педагогічні науки: теорія, історія, інноваційні технології: наук. журнал. Суми: ВиА-во СумАПУ імені А. С. Макаренка, 2018. № 1 (75). С. 209-225.

78. Заярна I. С. Особливості Аистанційного навчання англійського юриАичного аргументативного писемного мовцення на платформі Moodle // Актуацьні питання державотворення в Україні: матеріали Міжнародної науково-практичної конференції (19 травня 2017 року) / реАкол.: А.ю.н. І. С. Гриценко (голова), к.ю.н. І. С. Сахарук (віАп. реА.) та ін. В 2-х томах. Київ: ВПЦ «Київський університет», 2017. Том 2. С. 401-402.

79. Заярна I. С. Особливості застосування компетентнісного піАходу Ао навчання англійського аргументативного писемного мовцення майбутніх правознавців // Вісник Запорізького національного університету: збірник наукових праць. Педагогічні науки / Головний редактор Г. В. Аокарєва. Запоріжжя: Запорізький націонамьний університет, 2016. № 1. С. 159-165.

80. Заярна I. С. Особливості застосування методу Сократа до навчання англійського аргументативного писемного мовцення майбутніх правознавців // Ars linguodidacticae (Мистецтво Аінгводидактики): науковий журнал. Київ: ВПЦ «Київський університет», 2017. № 1. С. 48-53.

81. Заярна I. С. Особливості навчання англійського аргументативного писемного мовлення студентів-юристів засобами Аистанційного навчання // Вісник Кременчуцького національ- 
ного університету імені Михайла Остроградського. Педагогічні науки, 2018. № 2/201 (109). С. 35-44.

82. Заярна I. С. Принципи е-навчання англійського аргументативного письма майбутніх правознавців. Подолання мовних та комунікативних бар'єрів: освіта, наука, культура : збірник наукових праць. За реА. О. В. Ковтун, С. М. Ягодзінського. К. : HАУ, 2019. С. 231-235.

83. Заярна I. С. Психологічна комфортність як чинник ефективності Аистанційного навчання англійського аргументативного писемного мовлення студентів-правників // Роль інновацій в трансформації сучасної науки: матеріали Міжнародної науково-практичної конференції (м. Київ, 29-30 груАня 2017 р.) / ГО «Інститут інноваційної освіти»; Науково-навчальний центр приклаАної інформатики НАН України: у 2-х частинах. Київ: ГО «Інститут інноваційної освіти», 2017. Ч. 1. С. 21-23.

84. Заярна I. C. «Сократівська бесіда» як метод навчання англійського аргументативного писемного мовцення студентів-правників: деякі проблеми застосування / Scientific pedagogical internship «Legal education of the future: prospective and priority directions of scientific research»: Internship proceedings, November 27 - December 1. Lublin: Izdevnieciba «Baltija Publishing», 2017. 184 p.

85. Заярна I. С. Цімі та зміст навчання англійського аргументативного письма майбутніх правознавців / I. С. Заярна // Rozwój nowoczesnej edukacji i nauki - stan, poblemy, perspektywy [monografia] / [Redakcja naukowa: J. Grzesiak, I. Zymomrya, W. Ilnytskyj]. Konin — Użhorod - Kijów: Poswit, 2019. S. 76-85.

86. Зимняя И. А. Аингвопсихология речевой Аеятельности. Москва: Московский психолого-социальный институт; Воронеж: НПО «МОАЭК», 2001. 432 с.

87. Зимняя И. А. Психологические аспекты обучения говорению на иностранном языке. Москва, 1985. 
88. Зимняя И. А. Психология обучения неродному языку (на материале русского языка как иностранного). Москва: Русский язык, 1989. 219 с.

89. Іванова I. М. Психолінгвістичні передумови навчання професійно орієнтованого англомовного письма студентів-туризмознавців // Вісник КНАУ. Серія ПеАагогіка та психологія. 2015. Вип. 4. С. 38-45.

90. Каргин К. В. Понятие и элементы юридической аргументации: монография. Новгород: Нижегор. прав. акаА., 2011. 68 с.

91. Кейсова і подкаст технології формування міжкультурної компетентності : колективна монографія. О.Б. Бігич, А. А. Руснак, В. В. Стрілець, Т. І. Коробейнікова, О. В. Ярошенко, В. А. Ігнатенко / заг. і наук. реА. О. Б. Бігич. К. : ВиА. центр КНАУ, 2017. 160 c. URL: file://C:/Users/Омег/Downloads/Бігич\%20 текст\%20монографія\%202017\%20(кол.).pdf

92. Києнко-Романюк $\Lambda$. А. Розвиток критичного мислення студентської молоді як загальнопеАагогічна проблема: автореф. Аис. ... канА. пеА. наук: 13.00.01; Ін-т вищ. освіти АПН України. Київ, 2007. 22 с.

93. Киримлов В. И., Старченко А. А. Аогика: учебник Аля юриАических вузов / поА реА. проф. В. И. Киримлова. ИзА. 6-е, перероб. и Аоп. Москва: ТК Велби; ИзА-во Проспект, 2008. 240 с.

94. КАиминская С. $\Lambda$. Аингвостилистические средства реализации стратегий и тактик убеждения в аргументативном Аискурсе: на материале англоязычных телевизионных Аискуссий: автореф. Аис. ... канА. фимол. наук: 10.02.04; Моск. гос. Аингвист. ун-т. Москва, 2010. 25 с.

95. Козак $\Lambda$. В. Кейс-метоА у піАготовці майбутніх викмаАачів Ао інноваційної професійної Аіяльності // Освітологічний Аискурс. 2015. № 3 (11). С. 153-162.

96. Козмакова Г. О. Інформаційно-програмне забезпечення Аистанційної освіти: зарубіжний і вітчизняний АосвіА: монографія / АПН України; Ін-т вищ. освіти. Київ, 2002. 231 с. 
97. Коломієць А. А. Критерії відбору текстів Аля навчання ознайомлювального читання студентів немовних вузів техномогічних спеціальностей. URL: http://dspace.nuft.edu.ua/jspui/ bitstream/123456789/19806/1/45.pdf.

98. Колос К. Р. Система Moodle як засіб розвитку преАметних компетентностей учителів інформатики в умовах Аистанційної післяАипломної освіти: Аис. ... канА. пеА. наук: 13.00.10; Житом. Аерж. ун-т. ім. I. Франка. Житомир, 2011. 238 с.

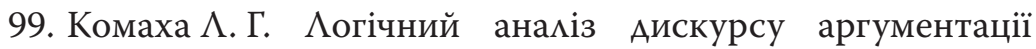
у філософії: Аис. ... А-ра. філос. наук: 09.00.06. Київ, 2016. 425 с.

100. Конверський А. Є. Аогіка: піАручник Аля студентів юриАичних факультетів. 3-тє виА. перероб. та Аоп. Київ: Центр учбової Аітератури, 2012. 296 с.

101. Конопценко $\Lambda$. О. Критерії віАбору професійно орієнтованих текстів Аця навчання вивчаючого читання майбутніх спеціалістів з захисту інформації // Вісник НТУУ «КПІ». Філомогія. Педагогіка. 2013. Випуск 1. С. 111-118.

102. Концепція розвитку Аистанційної освіти в Україні. URL: http://www.osvita.org.ua/distance/pravo/00.html.

103. Коробейнікова Т. I. Сучасні он-лайн сервіси організації самостійної роботи $з$ англійської мови Аля майбутніх перекцаАачів. Вісник Київського національного Аінгвістичного університету. Серія ПеАагогіка та психологія: зб. наук. праць. К. : КНАУ, 2019. Вип. 30. С. 97-102.

104. Котмовський А. М. Формування англомовної мексикограматичної компетентності в говорінні майбутніх економістів у процесі самостійної роботи: Аис. ... канА. пеА. наук: спец. 13.00.02. Тернопікь, 2017. 253 с.

105. Кравец В. А., Кухаренко В. А., Сиротенко Н. Г. КаАровое обеспечение Аистанционного обучения в университете // Информационные технологии в образовании, ИТО 2002: материалы XII Междунар. конф.-выставка, г. Москва, 4-8 ноября 2002 г. Москва, 2002. С. 63-65. 
106. Кремень В. Г. Аистанційна освіта - перспективний шлях розв'язання сучасних проблем розвитку професійної освіти // Вісн. АкаА. Аистанц. освіти. 2003. № 1. С. 4-11.

107. Крисак $\Lambda$. В. Методика навчання майбутніх Аікарів загальної практики англомовного професійно орієнтованого Аіалогічного мовлення: Аис. ... канА. пеА. наук: 13.00.02. Київ, 2016. 285 с.

108. Куримо А. В. Навчання майбутніх викмаАачів англійської мови професійно орієнтованого наукового писемного мовцення: Аис. ... канА. пеА. наук: 13.00.02. Київ, 2014. 409 с.

109. Кухаренко В. М., Молодих Г. С. Аналіз активності студентів в Аистанційному навчальному курсі // Нові інформаційні технології навчання в навчальних заклаАах України: наук. метод. зб. / реАкол.: I. I. Мархель (гол. реА.) та ін. ОАеса: ОАес. нац. морс. ун-т, 2002. Вип. 9. Ч. 1. 248 с.

110. Кухаренко В. М., Рибалко О. В., Сиротенко Н. Г. Гнучка розвивацьна Аистанційна система // Наук.-практ. конф., ХНУ, м. Харків, мистопаА, 2001 р. Харків, 2001. С. 69-72.

111. Ааврененко М. М. Профессионацьно-ориентированное обучение английскому языку студентов младших курсов юридических факультетов: Аис. ... канА. пеА. наук: 13.00.02; Моск. гос. откр. пеА. универ. им. М. А. Шолохова. Москва, 2004. 203 с.

112. АапиАус Б. А. Обучение второму иностранному языку как специальности: учеб. пособие. Москва: Высшая школа, 1980. 173 c.

113. Аеонтьев А. А. Язык, речь, речевая Аеятельность. КрасанА, 2010. 216 с.

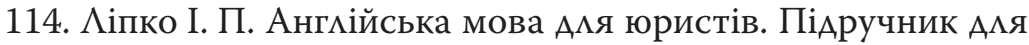
студентів та викцаАачів вищих навчальних закцаАів. - Вінниця: НОВА КНИГА, 2004. 208 с.

115. Аитвиненко I. Ю. Методика навчання студентів технічних спеціальностей англомовного читання на засадах інтеграції: Аис. ... канА. пеА. наук: 13.00.02. Херсон, 2015. 255 с. 
116. Аозова О. М. Психологічні аспекти засвоєння іноземної мови: навча^ьно-методичний посібник. Київ, 2010. 143 с.

117. Аопатніченко С. Є., Козолуп М. С., Мисик А. В. Англійська мова Аля студентів юридичних факультетів. Видання юриАичного факультету Аьвівського Аержавного університету імені Івана Франка. Аьвів. 1997.

118. Аубочников П. Г. Психологические механизмы развития образно-логического мышления субъекта в процессе когнитивной Аеятельности: Аис. ... канА. псих. наук: 19.00.01. Красноярск, 2004. 212 с.

119. Аурия А. Р. Основные проблемы нейролингвистики. Москва, 1975.

120. Аюбашенко О. В. Навчальні стратегї комунікативної інтеракції // Проблеми теорії і методики навчання іноземних мов. 2016. С. 292-298. URL: file://C:/Users/\%D0\%9E\%D0\% BB\%D0\%B5\%D0\%B3/Downloads/nvnau_fil.n_2016_245_42.pdf.

121. Аяховицкий М. В. Методика преподавания иностранных языков: учеб. пособ. Аля фимол. спец. вузов. Москва: Высшая школа, 1981. 159 с.

122. Аяшенко Р. А. Правова аргументація у сфері правотворчості // Учен. зап. Таврич. нац. ун-та им. В. И. ВернаАского. Серия «ЮриА. науки». 2012. Т. 25 (64). № 2. С. 74-79.

123. Майєр Н. В. Методика самостійного оволодіння франкомовним Аіловим писемним спілкуванням майбутніми документознавцями 3 використанням Аистанційних технологій: Аис. ... канА. пеА. наук: спец. 13.00.02. Київ, 2011. 286 с.

124. Маленький Б. І. Аргументативні стратегї̈ в німецькому економічному Аискурсі (на матеріалі жанру ток-шоу): Аис. ... канА. філол. наук: 10.02.04. Київ, 2018. 241 с.

125. Малкова Н. В. ВАияние конструктивистских идей на содержание подготовки учителя в США // ПеАагогика. 2008. № 2. C. 75-80. 
126. Маркобок Ю. В. Використання автентичних матеріалів Аля формування комунікативної та соціокультурної компетенції старшокласників на уроках англійської мови // Таврійський вісник освіти. 2014. № 1 (45). Частина I. С. 137-144.

127. Мелехина Е. А. Проблема целеполагания в обучении иностранным языкам Аля профессиональных целей. URL: https://lib.herzen.spb.ru/media/magazines/contents/1/109/ melyokhina_109_p_28_36.pdf.

128. Методика навчання іноземних мов і культур: теорія і практика : піАручник Аля стуА. кмасичних, пеАагогічних і Аінгвістичних університетів. Бігич О. Б., Бориско Н. Ф., Борецька Г. Е. та ін. За загальн. реА. С. Ю. Ніколаєвої. К. : Аенвіт, 2013. 590 с.

129. Методика навчання іноземних мов у загальноосвітніх навчальних закмадах: підручник / $\Lambda$. С. Панова, I. Ф. Андрійко, С. В. Тезікова та ін. Київ: ВЦ «Академія», 2010. Серія «Альмаматер». 328 с.

130. Методика викмадання іноземних мов у середніх навчальних закцадах: підручник. ВиА. 2-е, випр. і перероб. / кол. авторів піА керівн. С. Ю. Ніколаєвої. Київ: Аенвіт, 2002. 328 с.

131. Мимлет М. Критерии отбора текстового материала Аля обучения чтению на русском языке студентов вузов Кубы // Навстречу VI конгрессу МАПРЯ А. С. 80-84.

132. Мисик $\Lambda$. В., Савка І.ЧВ. Англійська юридична мова: комунікат. аспект: підруч. Аля стуА. юриА. та ін. гуманіт. спец.; за реА. А. В. Мисик. Київ: Ін Юре, 2013. 288 с.

133. Михайленко О. А. Методика навчання майбутніх філомогів стратегій письмового переклаАу офіційно-Аілових текстів з української мови на англійську: Аис. ... канА. пеА. наук: 13.00.02. Київ, 2015. 258 с.

134. Мінь М. Методика навчання усного китайського Аіалогічного мовлення майбутніх філологів: Аис. ... канА. пеА. наук: 13.00.02. Київ, 2018. 199 с. 
135. Морзе Н. В., Аементієвська Н. П. Навчання Аля майбутнього: посіб. Аля вчителів. Київ: Видав. група «ВНV», 2005. 420 с.

136. Морська $\Lambda$. I. Формування вмінь професійного спі кування англійською мовою у студентів факультету фізичного виховання: автореф. Аис. ... канА. пеА. наук: 13.00.02; Київський Аержавний Аінгвістичний університет. Київ, 2001. 20 с.

137. Москалець О. О. Етапи навчання іншомовного писемного мовцення як засобу спілкування. URL: file://C:/Users/ \%D0\%9E\%D0\%BB\%D0\%B5\%D0\%B3/Downloads/Nzspp_2012_ 6_20.pdf.

138. Мусульбес С. Н. Обучение аргументирующему Аискурсу в сфере письменного общения: (языковой вуз, продвинутый этап, английский язык): автореф. Аис. ... канА. пеА. наук: 13.00.02; Моск. гос. Аингв. ун-т. Москва, 2005. 24 с.

139. Мусульбес С. Н. Обучение аргументирующему Аискурсу в сфере письменного общения: (языковой вуз, продвинутый этап, английский язык): Аис. ... канА. пеА. наук: 13.00.02; Моск. гос. Аингв. ун-т. Москва, 2005. 202 с.

140. Назаренко I. М. Критерії віАбору текстів Аля навчання читання майбутніх фахівців 3 інформаційної безпеки. URL: http://confesp.fl.kpi.ua/node/1155.

141. Никишов А. А., Сюлькова Н. В. Инновационные техномогии Аистанционного образования сельского населения: учеб. пособие. Москва: РУАН, 2008. 196 с.

142. Овсянников В. И. Исследование психолого-педагогических основ Аистанционного образования // Открытое образование. 2004. № 2. С. 7-14.

143. Оганесян С. Г. Аргументация, её предметная область и возможности: автореф. Аис. ... А-ра филос. наук: 09.00.01; Ереванский гос. ун-т. Ереван, 1997. 39 с.

144. Окопна Я. В. Система Moodle в Аистанційному професійно орієнтованому навчанні Аругої іноземної мови 
майбутніх працівників туристичної сфери: мережева підтримка навчально-виховного процесу. URL: http:/enpuir.npu.edu.ua/ bitstream/123456789/9623/1/Okopna.pdf

145. Орловська $\Lambda$. К. Методичні рекомендації щодо формування усно мовленнєвої граматичної компетенції у майбутніх учителів англійської мови як Аругої іноземної // Теоретичні питання культури, освіти і виховання: збірник наукових праць. КНАУ. 2013. Вип. 47. С. 94-97.

146. Охріменко В. I. Мінгвокогнікативні та прагматичні аспекти аргументації в іспаномовній рекламі: Аис. ... канА. філол. наук: 10.02.05. Київ, 2002. 233 с.

147. Ощепкова Н. А. Стратегии и тактики в аргументативном Аискурсе: прагмалингвистический анализ убедительности рассужАения: (на материале политических дебатов): автореф. Аис. ... канА. филол. наук: 10.02.19; Калужский гос. пеА. ун-т им. К. Э. Циолковского. Калуга, 2004. 18 с.

148. Пассов Е. И. Основы коммуникативной методики обучения иноязычному общению. Москва: Рус. яз., 1989. 276 с.

149. Патієвич О. В. Компоненти, критерії оцінки та показники рівня сформованості умінь академічного писемного мовлення студентів магістратури природничого профілю // ПеАагогічні науки: збірник наукових праць. 2016. Випуск LXXIII. Том 1. C. 67-72.

150. Патієвич О. В. Методика навчання стилістичної унормованості наукового писемного англійського мовлення майбутніх фізиків в умовах магістратури: Аис. ... канА. пеА. наук: 13.00.02; М-во освіти і науки України, Київ. нац. ун-т імені Тараса Шевченка. Київ, 2015. 276 с.

151. Петренко С. В. Оптимізація й анаціз результатів використання LMS MOODLE у системі змішаного навчання в університеті // Інформаційні технології і засоби навчання. 2017. Том 61 (№ 5). С. 140-150. 
152. Пірог I. I. Аргументація в сучасній німецькій публіцистиці: прагмалінгвістичний аспект (на матеріалі економічних текстів): автореф. Аис. ... канА. філол. наук: 10.02.04; Харк. нац. ун-т ім. В. Н. Каразіна. Харків, 2009. 20 с.

153. Пкахотник В. М. Чи можуть вправи бути комунікативними // Іноземні мови. Київ, 2009. № 3. С. 3-5.

154. Полат Е.С., Бухаркина М. Ю., Моисеева В. М., Петров А. Е. Современные пеАагогические и информационные технологии в системе образования: учеб. пособие Аһя стуА. пеА. вузов и системы повыш. квалиф. пеА. каАров; поА реА. Е. С. Полат. 4-е изА., стер. Москва: ИзАательский центр «Академия», 2009. 272 с.

155. Політюк А. П. Аргументація як преАмет неформальних АосліАжень: неформацьна могіка та риторична аргументація: Аис. ... канА. філос. наук: 09.00.06. Київ, 2015. 220 с.

156. Про вищу освіту: Закон України віА 01.07.2014 № 1556VII // Голос України. 2014. № 148.

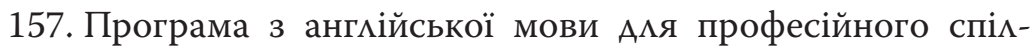
кування. Колектив авторів: Г. Є. Бакаєва, О.А.Борисенко, I. І. Зуєнок, В. О. Іваніщева, А. Й. Клименко, Т. І. Козимирська, С. І. Кострицька, Т. І. Скрипник, Н. Ю. Тодорова, А. О. Ходцева. Київ: Аенвіт, 2005. 119 с.

158. Про затверАження Положення про Аистанційне навчання: наказ МОН України віА 25.04.2013 № 466 // Урядовий кур'єр. 2013. № 155.

159. Про Націонацьну Аоктрину розвитку освіти: Указ ПрезиАента України віА 17.04.2002 № 347/2002 // Офіційний вісник України. 2002. № 16. С. 11.

160. Про Національну програму інформатизаціі: Закон України віА 04.02.1998 № 74/98-ВР // Офіційний вісник України. 1998. № 10. С. 5.

161. Про освіту: Закон України віА 05.09.2017 № 2145-VIII // Урядовий кур'єр. 2017. № 186. 
162. Психология веб-дизайна. Как цвета, шрифты и разметка влияют на ваше настроение. URL: http://lpgenerator.ru/blog/ 2016/03/14/psihologiya-veb-dizajna-kak-cveta-shrifty-i-razmetkavliyayut-na-vashe-nastroenie/.

163. Рабінович П. Правова аргументація (вихіАні загацьнотеоретичні характеристики) // ЮриА. вісн. України. 2015. № 17-18. C. $18-29$.

164. Рабінович П. М., Аудаш Т. I. Правова аргументація: терміно-поняттєвий інструментарій АосліАження // Вісник Націонацьної академії правових наук України. 2016. № 2 (85). C. 8-20.

165. Редько В. Г. Принципи добору навчальних матеріалів Ао змісту елективних курсів з іноземних мов Аля учнів старшої школи. URL: http://lib.iitta.gov.ua/704067/1/РеАько_Принципи_ Аобору.PDF.

166. Руаніцька К. В., Ароздова В. В. Організація самостійної роботи студентів засобами MOODLE в процесі навчання іноземної мови // Інформаційні технології і засоби навчання. 2018. Том 63 (№ 1). С. 227.

167. Руаніцька К. В. Сутність понять «компетентнісний піАхіА», «компетентність», «компетенція», «професійна компетентність» у світлі сучасної освітньої парадигми / Науковий вісник Ужгородського університету. 2016. Серія: «Педагогіка. Соціальна робота». Випуск 1 (38). С. 241-244.

168. Румянцева Т. А. Обучение аргументативному общению студентов 3 курса языкового педагогического вуза: (на материале немецкого языка): Аис. ... канА. пеА. наук: 13.00.02; Пензенский гос. пеА. наук им. В. Г. Белинского. Пенза, 1999. 240 с.

169. Свиридюк В. П. Методика навчання німецького писемного мовлення студентів-заочників вищих мовних навчальних закцаАів на основі використання Аистанційного курсу: автореф. Аис. ... канА. пеА. наук: 13.00.02; КНАУ. Київ, 2007. 19 с. 
170. Семенчук Ю. О. Критерії відбору фахових текстів Аля навчання студентів-економістів професійно спрямованої англійської мови // Вісник Житомирського Аержавного університету. ПеАагогічні науки. Випуск 55. С. 94-97.

171. Сисоєва С. О., Кристопчук Т. Є. Методологія науково-педагогічних АосліАжень: піАручник. Рівне: Волинські обереги, 2013. 360 с.

172. Ситуаційна методика навчання: теорія і практика / упор. О. Сидоренко, В. Чуба. Київ: Центр інновацій та розвитку, 2001. $256 \mathrm{c}$.

173. Скмяренко Н. К. Сучасні вимоги Ао вправ Аля формування іншомовних мовленнєвих навичок та вмінь // Іноземні мови. 1999. № 3. С. 3-7.

174. Скуратовська Т. А. Аргументація в американському судовому Аискурсі (на матеріалі справ заучастю суду присяжних): автореф. Аис. ... канА. філол. наук: 10.02.04. Київ, 2002. 20 с.

175. Смирнова-Трибульска Є. М. Аистанційне навчання 3 використанням системи Moodle: навчально-методичний посібник. Херсон: Айлант, 2007. 492 с.

176. Спірін О. М. Інформаційно-комунікаційні та інформатичні компетентності як компоненти системи професійно-спеціалізованих компетентностей вчитекя інформатики // Інформаційні технології і засоби навчання. 2009. 5 (13). URL: file://C:/Users/\%D0\%9E\%D0\%BB\%D0\%B5\%D0\%B3/Downloads/ 183-Article\%20Text-535-1-10-20100826.pdf

177. Спірін О. М., Вакалюк Т. А. Критерії Аобору віАкритих web-орієнтованих технологій навчання основ програмування майбутніх учителів інформатики // Інформаційні техномогії і засоби навчання. 2017. Том 60. № 4. С. 275-287. URL: file://C:/Users/\%D0\%9E\%D0\%BB\%D0\%B5\%D0\%B3/Downloads/ 1815-Article\%20Text-7808-1-10-20170929.pdf

178. Спірін О. М., Колос К. Р. Педагогічний експеримент 3 розвитку преАметних компетентностей учителів 
інформатики засобами Аистанційного навчання // Iнформаційні технології і засоби навчання. 2011. №5 (25). URL: file://C:/Users/\%D0\%9E\%D0\%BB\%D0\%B5\%D0\%B3/Downloads/ 555-Article\%20Text-1762-1-10-20111203.pdf

179. Сурмін Ю. П. Кейс-метод: становлення та розвиток в Україні // Вісник НААУ. 2015. № 2. С. 19-28.

180. Сухарева О. Э. Западная риторическая традиция и пробцема убедительности монолога: на материале публичной речи: автореф. Аис. ... канА. филол. наук: 10.02.19; УАмурт. гос. ун-т. Ижевск, 2010. 22 с.

181. Тарнопольський О. Б. Методика викладання іноземних мов та їх аспектів у вищій школі: ПіАручник. О. Б. Тарнопольський, М. Р. Кабанова. Аніпро: Університет імені АльфреАа Нобемя, 2019. 256 с.

182. Тарнопольський О. Б., Кожушко С. П. Методика навчання студентів вищих навчальних закладів письма англійською мовою. Вінниця: Нова книга, 2008. 288 с.

183. Трикашна Ю. І. Формування англомовної соціокультурної компетентності у майбутніх філологів з використанням автентичного художнього фільму: Аис. ... канА. пеА. наук: 13.00.02. Київ, 2017. 394 с.

184. Триус Ю. В., Герасименко I. В., Франчук В. М. Система електронного навчання ВН3 на базі Moodle: Методичний посібник / за реА. Ю. В. Триуса, Ю. А. Чабаненко. Черкаси, 2012. $220 \mathrm{c}$.

185. Туласынова Н. Ю. Развитие критического мышления студентов в процессе обучения иностранному языку: Аис. ... канА. пеА. наук: 13.00.01. Якутск, 2010. 203 с.

186. УАовіченко Г. М. Формування преАметних компетентностей студентів філологічних спеціальностей у процесі вивчення гуманітарних Аисциплін: автореф. Аис. ... канА. пеА. наук: спец. 13.00.09 «Теорія навчання». Кривий Ріг, 2012. 20 с. 
187. Умрик М. А. Організація самостійної роботи майбутніх учителів інформатики в умовах Аистанційного навчання інформатичних Аисциплін: автореф. Аис. ... канА. пеА. наук: 13.00.02; КПУ ім. М. П. Арагоманова. Київ, 2008. 24 с.

188. Хара О. М. Аистанційне навчання математики абітурієнтів у системі Аовузівської піАготовки: автореф. Аис. ... канА. пеА. наук: 13.00.02; КПУ ім. М. П. Арагоманова. Київ, 2010. 19 с.

189. Хара О. М. Психологічні особливості Аистанційного навчання математики // Математика в школі. 2008. № 7/8. C. 32-35.

190. Хоменко I. В. Аогіка: теорія та практика: підручник. Київ: Центр учбової Аітератури, 2010. 400 с.

191. Хоменко Н. С. Англійська мова Аля юристів - English for Law Students: Навч. посіб. з англ. мови Аля стуА. юриА. фак.. К.: МАУП, 2003. - 120 с.

192. Цепкало О. В. Методика навчання комунікативних стратегій професійно спрямованого англомовного писемного спілкування майбутніх фахівців з машинобудування: Аис. ... канА. пеА. наук: 13.00.02; НТУ КПІ імені І. Сікорського. Київ, 2017. 244 с.

193. Чорна I. Ю. Формування у майбутніх маркетологів англомовної мексичної компетентності в письмі засобами кейс-техномогії : Аис. ... канА. пеА. наук: 13.00.02. Тернопіль, 2017. 268 с.

194. Шатилов С. Ф. Методика обучения немецкому языку в среАней школе. Москва: Просвещение, 1986. 221 с.

195. Шевелева С. А. Английский Аля юристов: учеб. пособие Аля вузов. Москва: ЮНИТИ-ААНА, 1999. 495 с.

196. Шевніна $\Lambda . Є$. Формування жанрової компетенції в англійському Аіловому писемному мовленні майбутніх менеАжерів туризму: автореф. Аис. ... канА. пеА. наук: 13.00.02; ПНПУ ім. К. А. Ушинського. ОАеса, 2012. 23 с.

197. Шелестюк Е. В. Текстовые категории аргументативности, суггестивности и императивности как отражение 
способов речевого воздействия // Вестник Чемяб. гос. ун-та. Сер. «Фимология. Искусствоведение». 2008. Вып. 26, № 30 (131). C. $170-175$.

198. Шиліна Г. А. Забезпечення Аопрофільного вивчення української мови в сучасній сереАній школі засобами Аистанційного навчання в системі Moodle // Щорічний науковий збірник Четвертої Міжнародної наукової Інтернет-конференції з україністики / упоряА. О. Новікова. Мюнхен-Берцін. 2014. Випуск 13. С. 603-611.

199. Шиліна Г. А. Методика Аистанційного навчання української мови учнів основної школи: Аис. ... канА. пеА. наук: 13.00.02; БерАян. Аерж. пеА. ун-т. Київ, 2016. 300 с.

200. Шуневич Б. І. Розвиток Аистанційного навчання у вищій школі країн Європи та Північної Америки: автореф. Аис. ... А-ра. пеА. наук: 13.00.01; Інститут вищої освіти Академії педагогічних наук України. Київ, 2008. 38 с.

201. Щербина О. Ю. Аогічний аналіз юридичної аргументації: Аис. ... А-ра. філос. наук: 09.00.06. Київ, 2014. 424 с.

202. Щукин А. Н. АингводиАактический энцикмопеАический словарь. Москва: Астрель; АТС; Хранитель, 2007. 746 с.

203. Щукин А.Н. Обучение иностранным языкам: теория и практика: учеб. пособ. Аля преподавателей и студентов. Москва: Фицоматис, 2006. 480 с.

204. Юнчик В. $\Lambda$. Методичні особливості Аистанційного навчання / Збірник наукових праць. Наукові записки Рівненського Аержавного гуманітарного університету. Випуск 7 (50), 2013. URL: file://C:/Users/\%D0\%9E\%D0\%BB\%D0\%B5\%D0\%B3/ Downloads/Ozfm_2013_7_67.pdf.

205. Ягупов В. В. Педагогіка - модель навчання (модель начального процесу). URL: http://eduknigi.com/ped_view.php?id=131.

206. Ярошенко О. В. Кейс-метоА як сучасна техномогія формування професійно орієнтованої компетент- 
ності в Аіалогічному мовленні майбутніх викцаАачів англійської мови. Іноземні мови. № 2 (78). 2014. С. 39-44. URL: file://C:/Users/\%D0\%9E\%D0\%BB\%D0\%B5\%D0\%B3/Downloads/ 122479-260958-1-SM\%20(1).pdf

207. Alcaraz, Enrique, and Brian Hughes. Legal Translation Explained. St. Jerome, Manchester, 2002.

208. Al-Ghanimi Q., Jameel Rashid. Teaching reading English academic texts to philology students: Ph. D. thesis: 13.00.02. Kyiv, 2017. 323 p.

209. Anderson T. Theory and practice of online learning. Athabasca University, 2004. 454 p.

210. Auerbach E. R. Competency-based ESL: One step forward or two steps back. TESOL Quarterly. 1986. Vol. 20 (3). P. 414-415.

211. Bates A. W. Technology, Open Learning and Distance Education. London, Routledge, 1995.

212. Brattseva E. F., Kovalev P. The power of case study method in developing academic skills in teaching Business English (time to play) // Liberal Arts in Russia. 2015. Vol. 4. No. 3. P. 234-242.

213. Brody S., Kuntz C., Neumann R. and Walter M. Source Book on Legal Writing Progress, American Bar Association. 1997.

214. Bykov V. Yu., Kuharenko V. M., Molodyh A. S. Influence of Learning Process Organization on Students' achievments in Distance Education // Інтернет-Освіта-Наука-2004: матеріали 4-і Міжнародної конф., м. Вінниця, Універсум. Вінниця, 2004. С. 43-45.

215. Callanan H., Edwards Linda. Absolute Legal English Book (English for International Law). Delta Publishing. 2010.

216. Cambridge English. Assessing Writing Performance. Level B2. URL: http://www.cambridgeenglish.org/images/cambridge-english-assessing-writing-performance-at-level-b2.pdf.

217. Cambridge English. Legal. International Legal English Certificate (ILEC). Handbook for teachers. URL: http://www.culturalneuquen.com.ar/Legal_web_PDF2013.pdf. 
218. Candlin C. N., Bhatia V. K., Jensen C. H. Developing legal writing materials for English second language learners: Problems and perspectives // English for Specific Purposes. 2002. No 21. P. 299-320.

219. Civil Law Self-Help Center. Filing A Complaint To Start Your Case. URL: http://www.civillawselfhelpcenter.org/self-help/ lawsuits-for-money/pleading-stage-filing-a-complaint-or-responding-to-a-complaint/241-filing-a-complaint-to-start-your-case.

220. Cole Jason R. Using Moodle: teaching with the popular open source course management system. Sebastopol, California: O’Reilly Community Press, 2005. 219 p.

221. Cropley A., Kahl T. Distance education and distance learning: Some psychological considerations / Distance Education. 1983. No 4 (1). C. 27-39.

222. Delling R. M. Towards a theory of distance education // ICDE Bulletin 13, 1987. P. 21-25.

223. Dougiamas M., Taylor P. C. Improving the effectiveness of tools for Internet-based education // Teaching and Learning Forum 2000, Curtin University of Technology. 2000.

224. Dougiamas M., Taylor P. C. Interpretive analysis of an internet-based course constructed using a new courseware tool called Moodle // Proceedings of the Higher Education Research and Development Society of Australasia (HERDSA) 2002 Conference, Perth, Western Australia. 2002.

225. Dougiamas M. and Taylor P. C. Moodle: Using Learning Communities to Create an Open Source Course Management System // Proceedings of the EDMEDIA. Conference, Honolulu, Hawaii. 2003.

226. Eemeren F., Grootendorst R., Henkeman F. Fundamentals of Argumentation Theory. New Jersey, 1996.

227. English for Lawyers. - Аля студентів юридичних спеціальностей - Хмемьницький: Хмельницький університет управління та права, 2011. - 290 с. 
228. English for Lawyers: піАруч. Аля стуА. вищ. навч. закц. / за реА. В. П. Сімонок. Харків: Право, 2011. 648 с.

229. Federal Practice Manual for Legal Aid Attorneys. Drafting a complaint. URL: http://www.federalpracticemanual.org/chapter4/ section1.

230. Feteris E., Feteris T. Foundamentals of Legal Argumentation: a Survey of Theories on Justification of Judicial Decisions // Argumentation Library. Dordrecht: Springer, 1999. Vol. 1. 225 p.

231. Frost A. English for Legal Professionals Oxford University Press Elt. 2009.

232. Gannage M. Structure your legal memorandum // Perspectives: Teaching Legal Research and Writing. Fall. 1999. Vol. 8. URL: https://info.legalsolutions.thomsonreuters.com/pdf/perspec/1999fall/1999-fall-11.pdf.

233. Haigh R. Legal English, 2nd ed, Taylor \& Francis e-Library. 2009.

234. Hiltunen R. Chapters on Legal English, Suomalainen Tiedeakatemia. Helsinki, 1999.

235. Holmberg B. The Evolution, Principles and Practices of Distance Education. Oldenburg: Bibliotheks und Information system der Universitat Oldenburg, 2005. No 171. P. 57.

236. Holmberg B. Theory and Practice of Distance Education. London, Routledge, 1995. Interpretations from an international perspective / Otto Peters. London: Kogan page Limited, 2001. 279 p.

237. Hutchinson T., Waters A. English for Specific Purposes: A Learning-Centered Approach. Cambridge: CUP, 1988. 183 p.

238. Hutchinson T., Waters A. Interface: English for technical communication. Longman, 1984. 128 p.

239. Jackson Jeffrey D. Socrates and Langdell in Legal Writing: Is the Socratic Method a Proper Tool for Legal Writing Courses // California Western Law Review. 2007. Vol. 43. No. 2, Article 2. URL: http://scholarlycommons.law.cwsl.edu/cwlr/vol43/iss2/2. 
240. Just English. Английский Аля юристов. Базовый Курс / Ю. А. Гуманова, В. А. Королева-МакАри, М. А. Свешникова, Е. В. Тихомирова; под реА. Т. Н. Шишкиной. Москва: ИКА «Зерцало-М», 2002. 256 с.

241. Kearney Mary K., Beth Beazley Mary. Teaching students how to «think like lawyers»: integrating Socratic Method with the writing process // Temple Law Review. 1991. Vol. 64. No. 4. P. 885-908.

242. Krois-Lindner A., Legal Trans. International Legal English Student's Book: A Course for Classroom or Self-Study Use. Cambridge University Press. 2011.

243. Krois-Lindner A., Firth M., Legal Trans. Introduction to International Legal English Student's Book: A Course for Classroom or Self-Study Use. Cambridge University Press, 2008.

244. Kukharenko V. M., Syrotenko N. G. A Competence Forming in a Distance Education // Інтернет-Освіта-Наука-2004: матеріали 4-ї Міжнародної конф. м. Вінниця. Вінниця: Універсум-Вінниця, 2004. C. 67-69.

245. Learning to Teach Online. Open and institutionally supported technologies. URL: http://bit.ly/coursera-ltto.

246. Lin Ch.-H. Using Moodle in a General Education English as a Second Language Program: Taiwanese College Student Experiences and Perspectives // Journal of Educational and Social Research MCSER Publishing. Rome-Italy, 2013. Vol. 3. No. 3. P. 97-104.

247. Mason C. The Lawyer's English Language Coursebook, Global Legal English Ltd. 2011.

248. Moodle. Pedagogy Electronic resource: URL: https://docs.moodle.org/21/en/Pedagogy.

249. Moor M. G. \& Kearsley G. Distance Education: A Systems View // Belmont, Wadsworth Publishing Company, 1996.

250. Nicholls R. The Psychology of the Internet // Psychology of the Future. 2001. № 4. P. 35-52. 
251. Nuttall Ch. Teaching Reading Skills in a Foreign Language. Oxford: Macmillan Heinemann, 1996. 282 p.

252. Preparing a legal memorandum. URL: http://legalresearch.org/writing-analysis/legal-memorandum/.

253. Rice I., William H. Moodle E-Learning Course Development: a complete guide to successful learning using Moodle. Birmingham: Packet Publishing, 2006. 236 p.

254. Roblyer M. D., \& Edwards J. Integrating educational technology into teaching. 2nd ed. Upper Saddle River. New Jersey: Merrill, 2000.

255. Sadler D. R. Specifying and promulgating achievement standards // Oxford Review of Education. 1987. No 13. P. 191-209.

256. Smith A. Preparing for Practice from behind the Bench: Opinion Writing as the «Heart and Soul» of the First Semester of Legal Writing // The Journal of the Legal Writing Institute. 2012. Vol. 18. P. 263-289.

257. Tiersma P. M. Legal Language. Chicago, 1999.

258. Toulmin S. E. The Uses of Argument. Cambridge, 2003. 259 p.

259. Veretina-Chiriac I Characteristics and Features of Legal English Vocabulary // Lingvistică şi Literatură. 2012. Vol 4 (54). P. 104-119.

260. Wegener R. \& Leimeister J. M.: Virtual Learning Communities: Success Factors and Challenges // International Journal of Technology Enhanced Learning (IJTEL). 2012. Number 5/6. Vol. 4. P. 383-397.

261. Wilson L. O. The Second Principle. URL: http:// thesecondprinciple.com/teaching-essentials/models-of-teaching/

262. Wlodkowski R. Enhancing adult motivation to learn. San Francisco: Jossey Bass, 1985.

263. Write a successful memo. URL: http://www.lexisnexis.com/ documents/pdf/20151221040917_large.pdf

264. Wu W.-Sh. The application of Moodle on an EFL collegiate writing environment // Journal of Education and Foreign Languages and Literature. 2008. June. V. 7. P. 45-56. 
265. Wydick R. Plain English for lawyers: Teacher's manual. 5th ed. Carolina: Academic Press; Durham; NC, 2005. 10 p.

266. Zaiarna I. S. Competency-based Approach to Teaching English Reasoning Writing to Law Students: General Characteristics // КАасичний університет у контексті викликів епохи (Classic University in the context of Challenges of the Epoch): матеріали українсько-польської Міжнародної наукової конференції (м. Київ, 22-23 вересня 2016 р.) / уклаА.: А. С. Філіпенко та ін. Київ: Київський націонахьний університет імені Тараса Шевченка, 2016. С. 149-150.

267. Zaiarna I. Letter of Advice as a Type of English Reasoning Writing of Law Students: Teaching Methods and Techniques // Актуальні питання Аержавотворення в Україні: матеріали Міжнародної науково-практичної конференції (м. Київ, 20 травня 2016 р.) / редкол.: А.ю.н. І. С. Гриценко (голова), к.ю.н. I. С. Сахарук (віАп. реА.) та ін. В 3-х томах. Київ: ВПЦ «Київський університет», 2016. Том 3. С. 287-289.

268. Zaiarna I. S. Psychological aspects of distance learning of English reasoning writing as a type of law students' learning activity // The unity of science: International scientific professional periodical journal, December, 2017 - January, 2018. Czech Republic, Prague, 2018. P. 27-32.

269. Zaiarna I. Some Features of Distance Learning of the English Language at Universities // Сучасні тенденції розвитку освіти і науки в інтердисциплінарному контексті: матеріали II-ї Міжнародної науково-практичної конференції, 24-25 березня 2016 р. / реАактори-упорядники: І. Зимомря, В. Імьницький. Ченстхова; Ужгород; Арогобич: Посвіт, 2016. С. 236-237.

270. Zaiarna I. S. The Model for E-Teaching English Reasoning Writing to Law Students Based on LMS MOODLE. Information Technologies and Learning Tools. Vol. 76. No. 2. 2020. P. 152-162. URL: https://journal.iitta.gov.ua/index.php/itlt/article/view/3332 


\section{$\triangle \mathrm{OA} \mathrm{ATKИ}$}

Аодаток А

Перелік піАручників та навчальних посібників ААя навчання юриАичній англійській мові

- Callanan H. and Linda Edwards (2010), Absolute Legal English Book (English for International Law), Delta Publishing.

- English for Lawyers : піАруч. Аля стуА. вищ. навч. закл. / за реА. В. П. Сімонок. - Х. : Право, 2011. - 648 с.

- Frost A. (2009), English for Legal Professionals, Oxford University Press Elt.

- Just English. Английский аля юристов. Базовый Курс. Ю. А. Гуманова, $\quad$ В. А. Королева-МакАри, М. $\Lambda$. Свешникова, Е. В. Тихомирова. Под реА. Т. Н. Шишкиной. - М.: ИКА «Зерцало-М», 2002. - 256 с.

- Krois-Lindner A., Firth M. and TransLegal (2008), Introduction to International Legal English Student's Book: A Course for Classroom or Self-Study Use, Cambridge University Press.

- Krois-Lindner A. and TransLegal (2011), International Legal English Student's Book: A Course for Classroom or Self-Study Use, Cambridge University Press.

- Mason C. (2011), The Lawyer's English Language Coursebook, Global Legal English Ltd.

- Английский аля юристов - English: We Study Law: учеб. пособие Аля студентов вузов, обучающихся по специальности 021100 «Юриспруденция» / [авт.-сост. Немировская Э. А. и Ар.]. - 2-е изА., испр. - М.: Аого Камерон: ИзА-во Омега- $\Lambda$; 2006. -376 c. 
- Аілова англійська мова Аля юристів: навч. посіб. / $\Lambda$. В. Боровецька, $\Lambda$. Т. Жукова, Н. М. Сініцина та ін. - К.: КНЕУ, 2006. - 276 c.

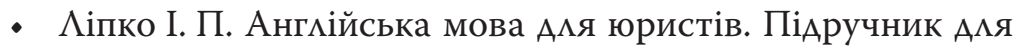
студентів та викмадачів вищих навчальних закладів. - Вінниця: НОВА КНИГА, 2004. - 208 с.

- Мопатніченко С. Є., Козолуп М. С., Мисик А. В. Англійська мова Аля студентів юриАичних факультетів. ВиАання юриАичного факультету Аьвівського державного університету імені Івана Франка. Аьвів. 1997.

- Мисик А. В. Англійська юридична мова: комунікат. аспект: підруч. Аля стуА. юриА. та ін. гуманіт. спец. / [Мисик $\Lambda$. В., Савка I. В.]; за реА. Мисик А. В. - Київ : Ін Юре, 2013. - 288 с.

- Хоменко Н. С. Англійська мова аля юристів - English for Law Students: Навч. посіб. з англ. мови Аля стуА. ЮриА. фак.. К.: МАУП, 2003. - 120 c.

- Шевелева С.ЧА. Английский Аля юристов: Учеб. пособие Аля вузов. - М.: ЮНИТИ-ААНА, 1999. - 495 с. 
Аодаток Б

\begin{abstract}
Опитування
на виявцення жанрів ангмійського аргументативного письма, які є найбімьш вживані в сучасній англомовній юридичній практиці України
\end{abstract}

Питання: Серед наведених нижче, відмітьте найбільш вживані письмові тексти у Вашій англомовній юридичній практиці (не більше 7):

1. Апемяційна записка

2. Апемяційна скарга

3. ВіАзив на позовну заяву

4. Заперечення на позов

5. Касаційна скарга

6. Кмопотання

7. Аист-відповідь на попередження

8. Аист-вимога

9. Аист-попередження

10. Аист-порада

11.Опис судової справи

12. Меморандум

13.Позовна заява

14. Постанова суау

15. Ухвала суау 
Аодаток В

Аодаток В1

Резумьтати передекспериментамьного зрізу в ЕГ-1

\begin{tabular}{|c|c|c|c|c|c|c|c|}
\hline Критерій & 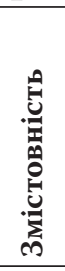 & 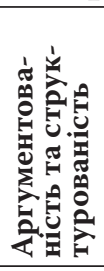 & 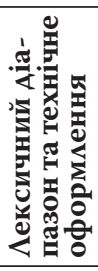 & 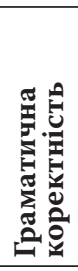 & 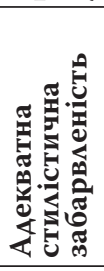 & 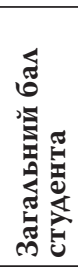 & 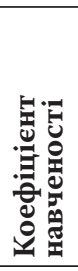 \\
\hline $\begin{array}{l}\text { Максимально } \\
\text { можливий бал }\end{array}$ & 5 & 5 & 5 & 5 & 5 & 25 & 1 \\
\hline А-ва О. & 4 & 3 & 4 & 4 & 4 & 19 & 0,76 \\
\hline Б-ук Р. & 2 & 2 & 3 & 4 & 4 & 15 & 0,60 \\
\hline Б-ва В. & 4 & 3 & 3 & 4 & 5 & 19 & 0,76 \\
\hline В-ва К. & 4 & 4 & 4 & 4 & 5 & 21 & 0,84 \\
\hline Г-ць I. & 3 & 3 & 3 & 4 & 3 & 16 & 0,64 \\
\hline Г-ва А. & 3 & 3 & 3 & 4 & 4 & 17 & 0,68 \\
\hline А-юк В. & 2 & 2 & 2 & 2 & 2 & 10 & 0,40 \\
\hline$A-c A$. & 2 & 2 & 2 & 2 & 3 & 11 & 0,44 \\
\hline Ж-ий М. & 3 & 3 & 3 & 2 & 4 & 15 & 0,60 \\
\hline 3-ий М. & 1 & 1 & 2 & 2 & 2 & 8 & 0,32 \\
\hline К-ко П. & 3 & 3 & 4 & 3 & 3 & 16 & 0,64 \\
\hline К-ук В. & 3 & 3 & 3 & 3 & 3 & 15 & 0,60 \\
\hline$\Lambda$-ко В. & 4 & 3 & 4 & 4 & 5 & 20 & 0,80 \\
\hline$\Lambda$-н O. & 3 & 3 & 3 & 4 & 4 & 17 & 0,68 \\
\hline М-ій O. & 2 & 1 & 2 & 2 & 3 & 10 & 0,40 \\
\hline М-т M. & 4 & 3 & 3 & 4 & 4 & 18 & 0,72 \\
\hline П-ов Б. & 3 & 2 & 3 & 4 & 4 & 16 & 0,64 \\
\hline Р-ко Я. & 2 & 1 & 2 & 3 & 3 & 11 & 0,44 \\
\hline С-ий О. & 4 & 2 & 3 & 4 & 3 & 16 & 0,64 \\
\hline С-ко О. & 3 & 3 & 3 & 4 & 3 & 16 & 0,64 \\
\hline С-й B. & 2 & 1 & 2 & 2 & 3 & 10 & 0,40 \\
\hline С-к B. & 1 & 1 & 2 & 2 & 2 & 8 & 0,32 \\
\hline С-ко В. & 3 & 3 & 3 & 3 & 3 & 15 & 0,60 \\
\hline Т-ко С. & 4 & 3 & 4 & 4 & 4 & 19 & 0,76 \\
\hline X-K K. & 3 & 3 & 4 & 4 & 3 & 17 & 0,68 \\
\hline Ш-к С. & 2 & 2 & 2 & 2 & 3 & 11 & 0,44 \\
\hline Середній бал групи & 2,85 & 2,42 & 2,92 & 3,23 & 3,42 & 14,84 & 0,59 \\
\hline
\end{tabular}


Аодаток В2

Резуиьтати передекспериментамьного зрізу в ЕГ-2

\begin{tabular}{|c|c|c|c|c|c|c|c|}
\hline $\begin{array}{r}\text { Шифр } \\
\text { стуАента }\end{array}$ & 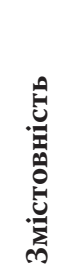 & 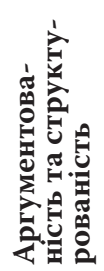 & 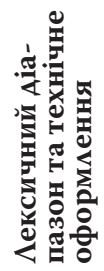 & 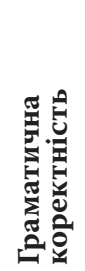 & 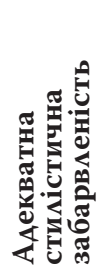 & 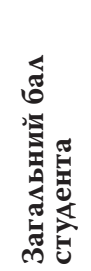 & 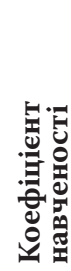 \\
\hline $\begin{array}{l}\text { Максимацьно } \\
\text { можмивий бац }\end{array}$ & 5 & 5 & 5 & 5 & 5 & 25 & 1 \\
\hline А-ич В. & 3 & 2 & 3 & 4 & 4 & 16 & 0,64 \\
\hline Б-єв O. & 3 & 3 & 3 & 3 & 4 & 16 & 0,64 \\
\hline Б-ов Я. & 2 & 2 & 2 & 2 & 2 & 10 & 0,40 \\
\hline Б-ко А. & 4 & 3 & 4 & 4 & 4 & 19 & 0,76 \\
\hline Б-к М. & 4 & 3 & 4 & 5 & 5 & 21 & 0,84 \\
\hline Б-ка I. & 1 & 1 & 2 & 2 & 2 & 8 & 0,32 \\
\hline В-ий В. & 1 & 1 & 1 & 1 & 2 & 6 & 0,24 \\
\hline Г-он I. & 3 & 2 & 3 & 3 & 4 & 15 & 0,60 \\
\hline Г-р Ю. & 4 & 3 & 4 & 4 & 5 & 20 & 0,80 \\
\hline Є-ва О. & 2 & 2 & 2 & 3 & 3 & 12 & 0,48 \\
\hline К-ва В. & 3 & 3 & 4 & 3 & 4 & 17 & 0,68 \\
\hline К-ук I. & 3 & 3 & 3 & 4 & 3 & 16 & 0,64 \\
\hline К-ва I. & 3 & 3 & 4 & 4 & 4 & 18 & 0,72 \\
\hline K-x B. & 3 & 3 & 4 & 3 & 3 & 16 & 0,64 \\
\hline К-ик А. & 2 & 1 & 2 & 2 & 3 & 10 & 0,40 \\
\hline M-ap A. & 3 & 3 & 3 & 3 & 3 & 15 & 0,60 \\
\hline М-ук M. & 2 & 2 & 2 & 2 & 2 & 10 & 0,40 \\
\hline П-ук О. & 3 & 3 & 3 & 5 & 4 & 18 & 0,72 \\
\hline П-ac I. & 3 & 3 & 3 & 4 & 4 & 17 & 0,68 \\
\hline П-ук I. & 4 & 4 & 3 & 4 & 4 & 19 & 0,76 \\
\hline C-ін I. & 5 & 3 & 4 & 4 & 4 & 20 & 0,80 \\
\hline С-ва A. & 3 & 2 & 3 & 3 & 4 & 15 & 0,60 \\
\hline Т-юк А. & 2 & 2 & 2 & 2 & 3 & 11 & 0,44 \\
\hline Т-ін М. & 3 & 3 & 4 & 3 & 3 & 16 & 0,64 \\
\hline Я-ук Ю. & 4 & 3 & 3 & 4 & 4 & 18 & 0,72 \\
\hline Я-ко М. & 2 & 1 & 2 & 2 & 2 & 9 & 0,36 \\
\hline Середній бам групи & 2,89 & 2,46 & 2,96 & 3,19 & 3,42 & 14,92 & 0,60 \\
\hline
\end{tabular}


Резуиьтати післяекспериментамьного зрізу в ЕГ-1

\begin{tabular}{|c|c|c|c|c|c|c|c|}
\hline $\begin{array}{r}\text { Шифр } \\
\text { стуАента }\end{array}$ & 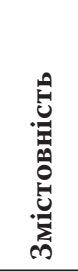 & 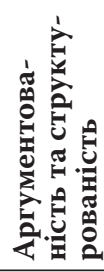 & 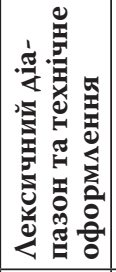 & 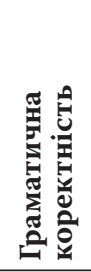 & 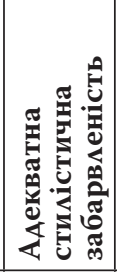 & 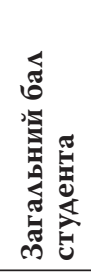 & 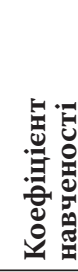 \\
\hline $\begin{array}{l}\text { Максимацьно } \\
\text { можливий бац }\end{array}$ & 5 & 5 & 5 & 5 & 5 & 25 & 1 \\
\hline А-ва O. & 5 & 5 & 4 & 4 & 5 & 23 & 0,92 \\
\hline Б-ук Р. & 5 & 4 & 4 & 4 & 4 & 21 & 0,84 \\
\hline Б-ва В. & 5 & 4 & 5 & 4 & 5 & 23 & 0,92 \\
\hline В-ва К. & 5 & 5 & 5 & 5 & 5 & 25 & 1,00 \\
\hline Г-ць I. & 4 & 4 & 3 & 4 & 4 & 19 & 0,76 \\
\hline Г-ва А. & 4 & 4 & 4 & 4 & 5 & 21 & 0,84 \\
\hline A-юк В. & 4 & 3 & 4 & 3 & 4 & 17 & 0,68 \\
\hline$A-c A$. & 4 & 4 & 3 & 4 & 4 & 19 & 0,76 \\
\hline Ж-ий М. & 4 & 4 & 4 & 4 & 4 & 20 & 0,80 \\
\hline 3-ий М. & 4 & 4 & 3 & 3 & 3 & 17 & 0,68 \\
\hline К-ко П. & 3 & 4 & 4 & 4 & 4 & 19 & 0,76 \\
\hline К-ук В. & 4 & 4 & 4 & 3 & 4 & 19 & 0,76 \\
\hline$\Lambda$-ко В. & 4 & 5 & 5 & 5 & 5 & 24 & 0,96 \\
\hline$\Lambda-\mathrm{H} \mathrm{O}$ & 4 & 5 & 4 & 4 & 4 & 21 & 0,84 \\
\hline М-ій O. & 4 & 4 & 4 & 3 & 5 & 20 & 0,80 \\
\hline М-т M. & 4 & 5 & 5 & 4 & 5 & 23 & 0,92 \\
\hline П-ов Б. & 4 & 4 & 4 & 4 & 5 & 21 & 0,84 \\
\hline Р-ко Я. & 3 & 4 & 4 & 3 & 4 & 18 & 0,72 \\
\hline С-ий O. & 4 & 5 & 4 & 4 & 4 & 21 & 0,84 \\
\hline С-ко О. & 4 & 4 & 5 & 4 & 3 & 20 & 0,80 \\
\hline С-й В. & 4 & 4 & 4 & 3 & 3 & 18 & 0,72 \\
\hline С-к В. & 3 & 3 & 4 & 3 & 4 & 17 & 0,68 \\
\hline С-ко В. & 3 & 4 & 4 & 4 & 4 & 19 & 0,76 \\
\hline Т-ко С. & 4 & 4 & 5 & 5 & 5 & 23 & 0,92 \\
\hline X-к K. & 3 & 4 & 5 & 5 & 4 & 21 & 0,84 \\
\hline Ш-к C. & 3 & 3 & 4 & 4 & 3 & 17 & 0,68 \\
\hline Середній бам групи & 3,88 & 4,12 & 4,15 & 3,89 & 4,19 & 20,23 & 0,81 \\
\hline
\end{tabular}


Резумьтати післяекспериментацьного зрізу в ЕГ-2

\begin{tabular}{|c|c|c|c|c|c|c|c|}
\hline Критерій & 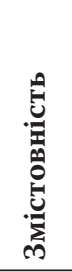 & 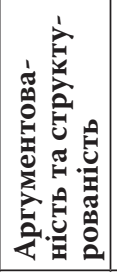 & 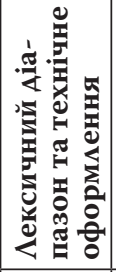 & 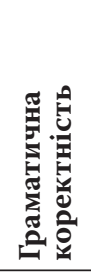 & 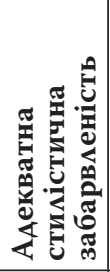 & 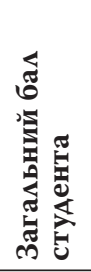 & 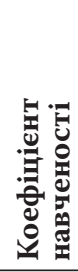 \\
\hline $\begin{array}{l}\text { Максимацьно } \\
\text { можливий бац }\end{array}$ & 5 & 5 & 5 & 5 & 5 & 25 & 1 \\
\hline А-ич В. & 4 & 3 & 4 & 4 & 4 & 19 & 0,76 \\
\hline Б-єв О. & 3 & 4 & 4 & 4 & 4 & 19 & 0,76 \\
\hline Б-ов Я. & 3 & 3 & 3 & 4 & 3 & 16 & 0,64 \\
\hline Б-ко А. & 4 & 4 & 4 & 5 & 5 & 22 & 0,88 \\
\hline Б-к M. & 4 & 3 & 5 & 5 & 5 & 22 & 0,92 \\
\hline Б-ка I. & 3 & 2 & 4 & 3 & 3 & 15 & 0,60 \\
\hline В-ий В. & 2 & 2 & 2 & 2 & 2 & 10 & 0,40 \\
\hline Г-он I. & 4 & 3 & 4 & 4 & 4 & 19 & 0,76 \\
\hline Г-р Ю. & 4 & 3 & 4 & 5 & 5 & 21 & 0,92 \\
\hline Є-ва О. & 3 & 3 & 3 & 4 & 4 & 17 & 0,68 \\
\hline К-ва В. & 3 & 3 & 4 & 4 & 4 & 18 & 0,72 \\
\hline К-ук I. & 3 & 3 & 3 & 4 & 4 & 17 & 0,68 \\
\hline К-ва I. & 4 & 3 & 4 & 4 & 4 & 19 & 0,76 \\
\hline K-x B. & 3 & 3 & 4 & 4 & 4 & 18 & 0,72 \\
\hline К-ик А. & 2 & 2 & 2 & 3 & 2 & 11 & 0,44 \\
\hline M-ap A. & 3 & 3 & 3 & 3 & 4 & 16 & 0,64 \\
\hline М-ук M. & 3 & 2 & 4 & 4 & 3 & 16 & 0,64 \\
\hline П-ук О. & 3 & 3 & 4 & 4 & 4 & 18 & 0,72 \\
\hline$\Pi$-ac I. & 3 & 2 & 5 & 4 & 4 & 18 & 0,72 \\
\hline П-ук I. & 4 & 3 & 4 & 4 & 5 & 20 & 0,84 \\
\hline C-ін I. & 4 & 4 & 4 & 5 & 5 & 22 & 0,88 \\
\hline С-ва А. & 3 & 2 & 4 & 4 & 5 & 18 & 0,72 \\
\hline Т-юк A. & 2 & 2 & 2 & 3 & 3 & 12 & 0,48 \\
\hline Т-ін М. & 3 & 3 & 4 & 4 & 4 & 18 & 0,72 \\
\hline Я-ук Ю. & 3 & 3 & 4 & 4 & 5 & 19 & 0,76 \\
\hline Я-ко М. & 2 & 2 & 2 & 2 & 3 & 11 & 0,44 \\
\hline СереАній бал групи & 3,15 & 2,81 & 3,62 & 3,85 & 3,92 & 17,35 & 0,69 \\
\hline
\end{tabular}


Аодаток В5

Ранжування показників коефіцієнту навченості за резуцьтатами передекспериментацьного зрізу

в ЕГ-1 та ЕГ-2

\begin{tabular}{|c|c|c|c|}
\hline $\begin{array}{c}\text { Коефіцієнт навченості } \\
\text { за таблицею передекс- } \\
\text { периментального зрізу } \\
\text { ЕГ-1 } \\
\end{array}$ & $\begin{array}{c}\text { Ранг } \\
\left(\mathrm{T}_{1}\right)\end{array}$ & $\begin{array}{c}\text { Коефіцієнт навченості } \\
\text { за таблицею передекс- } \\
\text { периментального зрізу } \\
\text { ЕГ-2 } \\
\end{array}$ & $\underset{\left(T_{2}\right)}{\text { Ранг }}$ \\
\hline 0,76 & 45 & 0,64 & 28,5 \\
\hline 0,60 & 20 & 0,64 & 28,5 \\
\hline 0,76 & 45 & 0,40 & 8,5 \\
\hline 0,84 & 51,5 & 0,76 & 45 \\
\hline 0,64 & 28,5 & 0,84 & 51,5 \\
\hline 0,68 & 36 & 0,32 & 3 \\
\hline 0,40 & 8,5 & 0,24 & 1 \\
\hline 0,44 & 13,5 & 0,60 & 20 \\
\hline 0,60 & 20 & 0,80 & 49 \\
\hline 0,32 & 3 & 0,48 & 16 \\
\hline 0,64 & 28,5 & 0,68 & 36 \\
\hline 0,60 & 20 & 0,64 & 28,5 \\
\hline 0,80 & 49 & 0,72 & 40,5 \\
\hline 0,68 & 36 & 0,64 & 28,5 \\
\hline 0,40 & 8,5 & 0,40 & 8,5 \\
\hline 0,72 & 40,5 & 0,60 & 20 \\
\hline 0,64 & 28,5 & 0,40 & 8,5 \\
\hline 0,44 & 13,5 & 0,72 & 40,5 \\
\hline 0,64 & 28,5 & 0,68 & 36 \\
\hline 0,64 & 28,5 & 0,76 & 45 \\
\hline 0,40 & 8,5 & 0,80 & 49 \\
\hline 0,32 & 3 & 0,60 & 20 \\
\hline 0,60 & 20 & 0,44 & 13,5 \\
\hline 0,76 & 45 & 0,64 & 28,5 \\
\hline 0,68 & 36 & 0,72 & 40,5 \\
\hline 0,44 & 13,5 & 0,36 & 5 \\
\hline & $\sum \mathrm{T}_{1}=678,5$ & & $\sum \mathrm{T}_{2}=699,5$ \\
\hline
\end{tabular}


Аодаток В6

Ранжування показників коефіцієнту навченості за резумьтатами післяекспериментального зрізу

в ЕГ-1 та ЕГ-2

\begin{tabular}{|c|c|c|c|}
\hline $\begin{array}{c}\text { Коефіцієнт навченості } \\
\text { за таблицею післяекс- } \\
\text { периментального зрізу } \\
\text { ЕГ-1 } \\
\end{array}$ & $\begin{array}{l}\text { Ранг } \\
\text { (T1) }\end{array}$ & $\begin{array}{c}\text { Коефіцієнт навченості } \\
\text { за таблицею післяекс- } \\
\text { периментального зрізу } \\
\text { ЕГ-2 } \\
\end{array}$ & $\begin{array}{l}\text { Ранг } \\
\text { (T2) }\end{array}$ \\
\hline 0,92 & 47,5 & 0,76 & 27,5 \\
\hline 0,84 & 39 & 0,76 & 27,5 \\
\hline 0,92 & 47,5 & 0,64 & 7 \\
\hline 1,00 & 52 & 0,88 & 43,5 \\
\hline 0,76 & 27,5 & 0,92 & 47,5 \\
\hline 0,84 & 39 & 0,60 & 5 \\
\hline 0,68 & 11,5 & 0,40 & 1 \\
\hline 0,76 & 27,5 & 0,76 & 27,5 \\
\hline 0,80 & 34 & 0,92 & 47,5 \\
\hline 0,68 & 11,5 & 0,68 & 11,5 \\
\hline 0,76 & 27,5 & 0,72 & 18,5 \\
\hline 0,76 & 27,5 & 0,68 & 11,5 \\
\hline 0,96 & 51 & 0,76 & 27,5 \\
\hline 0,84 & 39 & 0,72 & 18,5 \\
\hline 0,80 & 34 & 0,44 & 2,5 \\
\hline 0,92 & 47,5 & 0,64 & 7 \\
\hline 0,84 & 39 & 0,64 & 7 \\
\hline 0,72 & 18,5 & 0,72 & 18,5 \\
\hline 0,84 & 39 & 0,72 & 18,5 \\
\hline 0,80 & 34 & 0,84 & 39 \\
\hline 0,72 & 18,5 & 0,88 & 43,5 \\
\hline 0,68 & 11,5 & 0,72 & 18,5 \\
\hline 0,76 & 27,5 & 0,48 & 4 \\
\hline 0,92 & 47,5 & 0,72 & 18,5 \\
\hline 0,84 & 39 & 0,76 & 27,5 \\
\hline \multirow[t]{2}{*}{0,68} & 11,5 & 0,44 & 2,4 \\
\hline & $\sum \mathrm{T}_{1}=849,5$ & & $\sum \mathrm{T}_{2}=528,5$ \\
\hline
\end{tabular}




\section{Аинаміка змін показників коефіцієнту навченості} за резумьтатами передекспериментамьного

та післяекспериментамьного зрізів у ЕГ-1

\begin{tabular}{|l|c|c|c|}
\hline $\begin{array}{c}\text { Шифр } \\
\text { стуента }\end{array}$ & $\begin{array}{c}\text { Коефіцієнт навче- } \\
\text { ності за табмцею } \\
\text { передексперимен- } \\
\text { тамьного зрізу ЕГ- }\end{array}$ & $\begin{array}{c}\text { Коефіцієнт навче- } \\
\text { ності за таблицею } \\
\text { післяексперимен- } \\
\text { тального зрізу ЕГ- }\end{array}$ & $\begin{array}{c}\text { 3сув } \\
\text { з урахуванням } \\
\text { знака }\end{array}$ \\
\hline А-ва О. & 0,76 & 0,92 & $+0,16$ \\
\hline Б-ук Р. & 0,60 & 0,84 & $+0,24$ \\
\hline Б-ва В. & 0,76 & 0,92 & $+0,16$ \\
\hline В-ва К. & 0,84 & 1,00 & $+0,16$ \\
\hline Г-ць І. & 0,64 & 0,76 & $+0,12$ \\
\hline Г-ва А. & 0,68 & 0,84 & $+0,16$ \\
\hline А-юк В. & 0,40 & 0,68 & $+0,28$ \\
\hline А-с А. & 0,44 & 0,76 & $+0,32$ \\
\hline Ж-ий М. & 0,60 & 0,80 & $+0,20$ \\
\hline 3-ий М. & 0,32 & 0,68 & $+0,36$ \\
\hline К-ко П. & 0,64 & 0,76 & $+0,12$ \\
\hline К-ук В. & 0,60 & 0,76 & $+0,16$ \\
\hline$\Lambda$-ко В. & 0,80 & 0,96 & $+0,16$ \\
\hline$\Lambda$-н О. & 0,68 & 0,84 & $+0,16$ \\
\hline М-ій О. & 0,40 & 0,80 & $+0,40$ \\
\hline М-т М. & 0,72 & 0,92 & $+0,20$ \\
\hline П-ов Б. & 0,64 & 0,84 & $+0,20$ \\
\hline Р-ко Я. & 0,44 & 0,72 & $+0,28$ \\
\hline С-ий О. & 0,64 & 0,84 & $+0,20$ \\
\hline С-ко О. & 0,64 & 0,80 & $+0,16$ \\
\hline С-й В. & 0,40 & 0,72 & $+0,32$ \\
\hline С-к В. & 0,32 & 0,68 & $+0,36$ \\
\hline С-ко В. & 0,60 & 0,76 & $+0,16$ \\
\hline Т-ко С. & 0,76 & 0,92 & $+0,16$ \\
\hline Х-к К. & 0,68 & 0,84 & $+0,16$ \\
\hline Ш-к С. & 0,44 & 0,68 & \\
\hline & & & $+0,24$ \\
\hline
\end{tabular}


Publishing house "Liha-Pres"

9 Kastelivka str., Lviv, 79012, Ukraine 44 Lubicka str., Toruń, 87-100, Poland

Printed by the publishing house "Liha-Pres"

Passed for printing: May 18, 2020.

A run of 150 copies. 